UNIVERSIDADE DE SÃO PAULO

FFCLRP - DEPARTAMENTO DE PSICOLOGIA E EDUCAÇÃO

PROGRAMA DE PÓS-GRADUAÇÃO EM PSICOLOGIA

\title{
Vulnerabilidade e construções de enfrentamento da soropositividade ao HIV por mulheres infectadas em relacionamento estável.
}

Ana Alayde Werba Saldanha

Tese apresentada à Faculdade de Filosofia, Ciências e Letras de Ribeirão Preto da USP, como parte das exigências para a obtenção do título de Doutor em Ciências, Área: Psicologia.

RIBEIRÃO PRETO - SP 
UNIVERSIDADE DE SÃO PAULO

FFCLRP - DEPARTAMENTO DE PSICOLOGIA E EDUCAÇÃO

PROGRAMA DE PÓS-GRADUAÇÃO EM PSICOLOGIA

DEPARTAMENTO DE PSICOLOGIA E EDUCAÇÃO

Vulnerabilidade e construções de enfrentamento da soropositividade ao

HIV por mulheres infectadas em relacionamento estável.

Ana Alayde Werba Saldanha

Prof. Dr. Marco Antonio de Castro Figueiredo

Tese apresentada à Faculdade de Filosofia, Ciências e Letras de Ribeirão Preto da USP, como parte das exigências para a obtenção do título de Doutor em Ciências, Área: Psicologia.

RIBEIRÃO PRETO - SP 


\section{FICHA CATALOGRÁFICA}

Saldanha, Ana Alayde Werba

Vulnerabilidade e construções de enfrentamento da soropositividade ao HIV por mulheres infectadas em relacionamento estável. Ribeirão Preto, 2003.

205 p. : il.; $30 \mathrm{~cm}$

Tese, apresentada à Faculdade de Filosofia, Ciências e Letras de Ribeirão Preto / USP - Dep. de Psicologia e Educação.

Orientador: Figueiredo, Marco Antonio de Castro

1. Vulnerabilidade. 2. HIV/Aids. 3. Gênero

\section{Capa:}

Escultura "Mulher da Seca" - Artesão Popular: Samuel João Pessoa - PB

Fotografia: Marcelo Cleomar T. Simões

Ribeirão Preto - SP 
"Quando o homem compreende a sua realidade, pode levantar hipóteses sobre o desafio dessa realidade. Assim, pode transformá-la e com seu trabalho pode criar um mundo próprio: seu eu e suas circunstâncias."

Paulo Freire 
Ao

Paulo Sérgio,

Daniella,

Michelle,

Rafael

Que sempre me abastecem de amor para seguir nas minhas andanças. 
Ao meu pai,

exemplo de vida e dignidade, que precisou partir para semear amor em outros pagos.

"A morte é a curva da estrada, Morrer é só não ser visto." (Fernando Pessoa, 1932) 


\title{
AGRADECIMENTOS
}

\author{
... a vida é a arte do encontro, \\ embora haja tantos desencontros pela vida...
}

(Vinícius de Morais)

Julho de 1998. Chego em Ribeirão Preto, São Paulo.

Não venho sozinha. Trago comigo minhas filhas, Daniella e Michelle, companheiras na aventura de viver. Embora nem sempre satisfeitas com as mudanças, estão sempre ao meu lado, dando força nos momentos difíceis e comemorando nos momentos de alegria.

Trago comigo também, a saudade da família, especialmente dos meus pais, Saldanha e Raquel. Mas foram eles a ensinar que precisamos voar cada vez mais alto na busca de nossos ideais e, mesmo que isso nos leve para longe, temos a certeza da volta.

Comigo também está a presença da minha avó Maria, que mesmo distante no espaço, nunca se fez ausente.

Trago também o sorriso dos amigos, representado por Marcos e Fátima na Paraíba e pela Neneca no Rio Grande do Sul, cuja amizade torna a distância inexistente.

Minha vinda também se ancora na confiança depositada pelo grande amigo e eterno mestre, Prof. Dr. Mardônio Rique Dias, marco inicial na minha busca pelo conhecimento científico.

Meu vôo tinha um rumo certo. Vinha em busca de novas descobertas. E, como em tudo o que é novo, a insegurança pelo desconhecido se fazia presente. 
Insegurança esta que se dissipou, transformando-se em certeza e confiança no abraço de chegada, no carinho encontrado, no cuidado expressado por aquele que, além de enriquecer o reino das descobertas, ampliou as visões de mundo, estimulantes em suas pluralidades, numa contribuição corajosa, imprimindo dignidade à vida que vale a pena ser vivida: a vida com sentimentos. Este é o meu orientador, Prof. Dr. Marco Antonio de Castro Figueiredo. Não teria como agradecer por tantos momentos de dedicação, olhares críticos, transmissão de conhecimentos, encorajamento, solidariedade e tanto mais. Por isso prefiro celebrar. Celebrar o êxito desta etapa de trabalho, de vida, que não se encerra na última página desta teses. Ao contrário, tal qual a flor, que depois de desabrochar formosa, transforma-se novamente em semente para germinar novos jardins, as sementes deste trabalho serão carregadas em novos vôos, florescendo nos caminhos percorridos.

Era hora de começar o trabalho, de adentrar o mundo das pessoas que seriam o centro da minha pesquisa. Este encontro foi proporcionado pelo Dr. Geraldo Duarte, ao me receber como Psicóloga Voluntária no Ambulatório de Moléstias Infecto-Contagiosas de Ginecologia e Obstetrícia, do Hospital das Clínicas da Faculdade de Medicina de Ribeirão Preto - USP, onde permaneci por dois anos, contando ainda com a colaboração da $\mathbf{D r}^{\mathrm{a}}$. Silvana Quintans, com a presença amiga, sempre alegre e disposta da Dra . Marina Paschoini e da Assistente Social Andréa Cristina Medeiros Bossa companheira nas implantações de grupos de atendimento e confidentes nas histórias de vida.

É com um carinho muito especial que falo das mulheres que protagonizaram este estudo, que ao contarem-me suas Histórias de Vida, me 
ensinaram sobre a força e coragem de enfrentar um cotidiano sofrido e, mesmo assim, não perder a “mania de ter fé na vida”.

À CAPES, cujo apoio financeiro foi essencial ao desenvolvimento do estudo.

Foram tantas as pessoas com quem pude contar nessa trajetória, em seus mais diferentes papéis, todos importantes e concorrentes desta chegada. $\mathrm{Na}$ impossibilidade de espaço, as represento nas presenças marcantes da Prof ${ }^{\mathbf{a}}$. Dr ${ }^{\mathbf{a}}$. Alcyone Artioli Machado e do Prof. Dr. Manoel Antonio dos Santos, dos quais, além das idéias, contei com momentos amigos que muito me valeram. Não poderia faltar a Denise Cremonezi, cujo contato deixou de ser apenas técnico para, muito além disso, transformar-se em estima e admiração.

Também não poderia deixar de citar a disponibilidade e as valiosas contribuições a esta tese oferecidas pela Prof ${ }^{\mathrm{a}}$. Dr ${ }^{\mathrm{a}}$. Elucir Gir e Prof ${ }^{\mathrm{a}}$. Dr ${ }^{\mathrm{a}}$. Eucia Beatriz, ao comporem a Banca de Qualificação.

Sônia, Van e Rui, Mirian e Marcelo, Marcio, Edson, Ana Celeste, Jéferson, Bernardo e Ísis, Percy, Taís, Lícia, Luciana, Lupércio... impossível nomear a todos, pessoas tão especiais que passaram a fazer parte da minha vida. Pessoas que me tornaram, além de gaúcha por nascimento e paraibana de coração, ribeirãopretana por opção.

Encerrando - como se possível fosse encerrar - esta história de encontros felizes, desejo celebrar com todos, o amor em todas suas expressões. É este o amor que descobri com Paulo Sérgio Pichelli, que cantando me encantou e tornou minha vida ainda mais bonita e cheia de significados. Um amor que se personificou com a 
presença de Rafael, a nossa alegria e marca maior de nossa estadia em Ribeirão Preto.

Chegada a hora de novamente alçar vôo, mais do que agradecer, desejo com vocês, celebrar a vida!

Até breve!!!!!! 


\section{RESUMO}

\section{SUMMARY}

\section{APRESENTAÇÃO}

1. INTRODUÇÃO

1.1 - AIDS: Trajetória e tendências da epidemia ........................................ 16

1.2 - Desigualdade de gênero: uma herança histórica.................................. 33

1.3 - AIDS: Desafios de um novo tempo............................................... $\quad 70$

1.4 - Justificativa e Objetivo............................................................... $\quad 76$

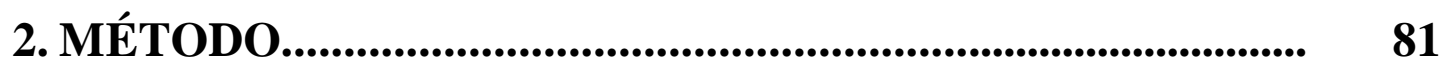

2.1 - Referencial metodológico: Representações Sociais .............................. 81

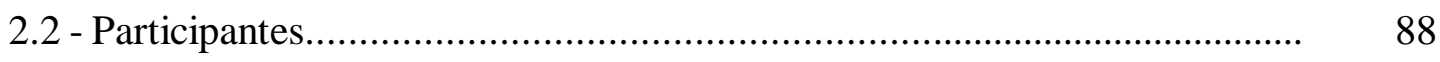

2.3 - Instrumento de Coleta de Dados ................................................... 89

2.4 - Procedimento de Coleta de Dados..................................................... 90

2.5 - Procedimento de Analise de Dados ..................................................... $\quad 90$

2.6 - Aspectos Éticos ........................................................................... 93

3 - RESULTADOS E DISCUSSÃO............................................. 94

3.1 - Trajetória de Vida.............................................................................. 94

3.2 - Caracterização dos Participantes........................................................... 94

3.3 - Categorias Temáticas Enunciadas ....................................................... 101 
A - A Soropositividade no Cotidiano da Mulher..................................... 102

B - Relacionamento Afetivo-Sexual................................................. 138

C - A prática em Saúde no Discurso da Mulher Soropositiva................... 180

4 - CONSIDERAÇÕES FINAIS................................................... 200

4.1 - Projeto de Intervenção..................................................................... 210

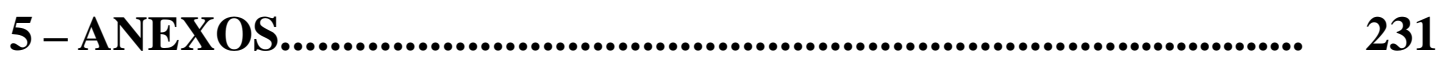

Síntese das Histórias de Vida.................................................................. 232

6 - REFERÊNCIAS BIBLIOGRÁFICAS................................ 249 


\title{
RESUMO
}

\author{
SALDANHA, A.A.W. Vulnerabilidade e Construções de Enfrentamento da \\ soropositividade ao HIV por mulheres infectadas em relacionamento estável. \\ 2003. Tese de Doutorado - Pós-Graduação em Psicologia. Faculdade de Filosofia, \\ Ciências e Letras de Ribeirão Preto. Universidade de São Paulo.
}

Os fatores políticos e econômicos que impulsionaram a epidemia de HIV/AIDS estão também intimamente ligados à organização social das estruturas de gênero e sexualidade, cujas hierarquias fazem das mulheres - em especial àquelas dos segmentos de baixa renda - extremamente vulneráveis à infecção pelo HIV. Partindo do pressuposto de que a vida cotidiana é tecida por conceitos historicamente condicionados, reapropriados e reconstruídos pelos indivíduos, este estudo visa, através da história de vida de mulheres soropositivas, contaminadas em relacionamento estável, compreender de que forma se dá a atribuição do significado da soropositividade e de que forma influenciam na (re)construção da sua identidade e na construção do seu mundo. Foram entrevistadas 10 mulheres soropositivas para o HIV, com média de idade de 26 anos, tempo de diagnóstico variando de 2 a 10 anos, pertencentes à classe social menos favorecida, infectadas por via sexual pelo parceiro em relacionamento afetivo estável (tempo médio $=5$ anos). Para a coleta dos dados foi utilizada a técnica de História de Vida, por incorporar as experiências subjetivas mescladas a contextos sociais. De acordo com a abordagem qualitativa de pesquisa, para a análise dos dados foi utilizada a Teoria da Representação Social. Através das narrativas, foi elaborado um quadro enfocando os eventos importantes na trajetória de vida destas mulheres, possibilitando o estudo das similaridades e a inserção das narrativas no contexto social de cada época. Através da análise de conteúdo, surgiram as seguintes categorias temáticas: (1) A soropotividade no cotidiano da mulher; (2) Dinâmica das Relações Afetivas; (3) A prática da Saúde no Discurso da Mulher Soropositiva. Observou-se que o maior agravante da vulnerabilidade se dá pelas limitações no espaço de suas relações pessoais, principalmente no que se refere à relação conjugal, visto configurarem um sistema relativamente autônomo e autoregulado, onde as medidas preventivas são percebidas como externas ao sistema intimo. Além disso, evidenciaram-se situações de vulnerabilidade como conseqüência de uma naturalização, principalmente no que se refere às relações entre os gêneros. Salienta-se também a fragilidade da lógica racional, principalmente no que se refere ao modelo médico, que acredita que as representações e comportamentos constituem um sistema relativamente estável e coerente. Conclui-se pela importância da reconstrução da história de vida destas mulheres como base, tanto para o desenvolvimento de intervenções preventivas, como para o aperfeiçoamento dos serviços voltados para a saúde da mulher soropositiva. Com base nos resultados obtidos, foi apresentado um Projeto de Intervenção que consiste em propiciar um espaço de síntese e reconstrução, possibilitando a ressignificação das representações, experiências e práticas visando a redução da vulnerabilidade e construção de modos de enfrentamento ao HIV.

Palavras chaves: Aids, gênero, relações afetivas, saúde, vulnerabilidade 


\section{SUMMARY}

SALDANHA, A. A. W. Vulnerability and Building of Coping the HIV condition by infected women in a stable relationship. 2003. Doctorate Thesis - Post Graduation in Psychology. Faculdade de Filosofia, Ciências e Letras de Ribeirão Preto. Universidade de São Paulo.

The political and economical factors that impelled the HIV/SIDA epidemic are also closely linked to the social organization of the gender and sexual structures, which hierarchy have made women - specially those who are from the poor groups extremely vulnerable to be infected by HIV. Bearing in mind that daily life is made by historically conditional concepts, retaken and rebuilt by the individuals, this study aims, through the history of the infected women, contaminated in a stable relationship, understand in which way the attribution of the tern HIV positive and in which way influenced the rebuilding of their identity and building of their world. 10 HIV positive women are interviewed, at an average age of 26 years old, period of diagnosis varying between 2 and 10 years, belonging to the poor social classes, infected though sex by their partners in a stable relationship (average period $=5$ years). To the gathering of data the History of Life Technique was used, because it incorporates the mixed subjective experiences in social contexts. According to the qualitative approach, to the analysis of the data the Social Representation Theory was used. Though the narratives, a chart was elaborated focusing on important events in the life trajectories of these women, permitting the study of the similarities and the insertion of the narratives in the social context of each epoch. Though the content analysis, the following thematic categories came up: (1) The HIV positive in the daily life of the woman; (2) Dynamic of the Affectionate Relationships; (3) The practice of the Health in the Discourse of the HIV positive woman. It was observed that the biggest aggravation of the vulnerability is due to the space limitation in their personal relationships, mainly in what refers to the marital relationship, as it constitutes a relatively autonomous an auto-regulated system, where the preventive measures are perceived as external to the intimate system. Apart from this, vulnerable situations were evident as consequences of a naturalization, mainly in what refers to the relationships between genders. It is also pointed out that the rational logic fragility, mainly in what refers to the medical model, which believes that the representations and behaviour constitute a relatively stable and coherent system. It is concluded by the importance of the reconstruction of these women's lives having as a base, both for the development of preventive interventions and for the improvement of the services done to the health of the HIV positive woman. Having base in the obtained results, it was presented an Intervention Project in which constitutes in promoting a synthesis and reconstruction space, permitting the re-aim of representations, experiences and practices aiming the reduction of vulnerability and construction of HIV coping strategies.

Key words: SIDA, gender, Affectionate Relationships, health, vulnerability 


\section{APRESENTAÇÃO}

A Aids parecia tão distante... até aquela manhã, já no final da década de 1980, quando, ao entrar nas enfermarias da Maternidade onde trabalhava, deparei-me com uma delas fechada, com uma paciente no isolamento. Soube tratar-se de uma mulher, cuja sorologia positiva para o HIV assustava à todos. Ela aguardava, sozinha, até que fosse removida para outro hospital...

Foi assim que a Aids passou a fazer parte da minha vida. Como disse Dalton Ramos (2001:xi), “o vírus pode não estar em nossa circulação, mas a Aids está definitivamente em nossas vidas e não se pode ser indiferente a ela..."

A partir de então, o interesse pelo tema me contagiou, tomou conta do meu trabalho e lançou-me na pesquisa, sempre junto das pessoas afetadas pelo HIV, pois esta é a melhor forma de aprender. Veio então, a Especialização, o Mestrado, chegando até esta tese de Doutorado.

Foram dois anos de atendimento e convivência junto a estas pessoas, conhecendo seu mundo, seu cotidiano, seus sentimentos, antes de me aventurar pela pesquisa propriamente dita. E cada depoimento foi um grande aprendizado.

Sempre fui de me apaixonar pelas pessoas, pelos momentos da vida, pelas causas que abraço. Assim, me apaixonei por este trabalho e todos que dele participaram. E longe de prejudicar, como tão bem citou Alves (2001: 07), “a paixão com discernimento pelo que se faz só pode aprimorar cada momento quando decidimos que assim poderemos fazer o melhor". 
Tendo como premissa o descompasso existente entre as atividades de prevenção e intervenção e a realidade social dos sujeitos, este estudo foi desenvolvido em três tempos: o tempo histórico, abordado na Introdução, que analisa a vulnerabilidade feminina como construída ao longo da história, desde as sociedades primitivas até os nossos dias, culminando com o aparecimento da Aids. Nesta incursão histórica, foram ressaltados dois pontos: a difusão das idéias do amor romântico que afetou a vida social como um todo, atuando ainda hoje como lugar de reasseguramento de identidade e, como segundo ponto, o discurso médico através dos tempos.

Por que estudar o discurso médico? Porque a medicina não é meramente uma arte de curar, é também meditação sobre a vida, morte, sofrimento. Os discursos médicos durante séculos têm estado emparelhados, por exemplo, com os discursos filosóficos; irmanados algumas vezes e enfrentando em outros, com os discursos religiosos, porém tem sido sempre peça-chave no conjunto dos dispositivos estratégicos através dos quais a sociedade produz homens e mulheres, principalmente no que se refere ao significado outorgado ao corpo das mulheres.

O segundo tempo estudado foi a História de Vida destas mulheres, na tentativa de revelar o ambiente dos acontecimentos que fazem parte da experiência e os processos sociais a partir das pessoas envolvidas.

E o tempo mais recente, a partir do diagnóstico da soropositividade para o HIV, abordando o cotidiano e as relações afetivas.

Como consequiência, foi avaliada a prática em saúde no discurso da mulher soropositiva, a partir da realidade vivida enquanto usuárias sistemáticas do sistema 
de saúde.

O Capítulo final buscou fazer uma síntese conduzindo à real percepção das dimensões sociais e psicológicas das mulheres soropositivas. E, como que a lembrar que este tema nunca se esgotará, "terminamos por onde se começa": com a apresentação de um Projeto de Intervenção.

Acredito ter abordado, desta forma, a vulnerabilidade e as construções de enfrentamento da soropositividade ao HIV por mulheres infectadas pelo parceiro.

Diz a lenda que certo dia, passeando pela praia, um homem viu um vulto que, a seus olhos, parecia dançar. Aproximando-se, curioso, viu que era um menino recolhendo cuidadosamente, da areia estrelas-do-mar e lançando-as, uma a uma, de volta ao oceano. Intrigado o homem indagou:

- Por que faz isso, meu jovem?

- É que a maré estando baixa, e o sol tão escaldante, elas vão secar e morrer!

- Mas, criança, são muitas as praias do mundo e quantos milhões de estrelas-do-mar não existirão por aí? São tão poucas as que você retorna ao mar. Que diferença fará, se a maior parte delas vai mesmo morrer?

Olhando de soslaio para o homem, a criança pegou mais uma estrela da areia e a jogou, carinhosamente, no mar. Virou-se, então, e sorrindo exclamou:

- Para essa eu fiz a diferença!

Mesmo que para poucas pessoas, se esse trabalho fizer a diferença, com certeza terá cumprido com seus objetivos! 


\section{INTRODUÇÃO}

\section{1 - AIDS: Trajetória e Tendências da Epidemia}

"São tão amplas e radicais as tensões trazidas pela experiência da AIDS que parecemos reviver o conturbado século XIX europeu, quando profundas transformações sociais tiveram nas epidemias emergentes da época seu espelho e imagem a um só tempo. Espelho porque tais epidemias expunham cruelmente às sociedades industriais que ali se desenvolviam suas características constitutivas. Imagem porque tal (re)conhecimento implicava a iniludivel necessidade destas sociedades assumirem $e$ enfrentarem suas próprias fragilidades e conflitos, desafios que não poderia ser escamoteado senão a custo de ameaçadores abalos nas bases normativas de sua sociedade" (Rosen, apud Ayres, 1998).

É assim que em 1970 surge a AIDS $^{1}$. Conforme Paulilo, (1999), uma doença cuja caracterização inicial foi apresentada pela ciência médica e reforçada pela mídia, era configurada pela morte, pelo contágio, pelo sexo. Domínios estes, que comportam componentes emocionais profundamente enraizados pela cultura e que causam enorme impacto no plano simbólico. A incerteza da ciência, os mecanismos de transmissão, as representações ligadas às catástrofes e as pestes foram (re)criadas e difundidas na mesma intensidade que tomou conta de uma sociedade que se percebeu novamente vulnerável (Figura 1).

Os estudos epidemiológicos iniciais passaram a buscar ativamente os fatores de risco associáveis à doença, dando origem aos "grupos de risco", expressão esta, que embora superada, marcou irreversivelmente a construção social e histórica

\footnotetext{
${ }^{1}$ AIDS vem da expressão em inglês Acquired Imunedeficiency Síndrome, traduzida em português para Síndrome da Imunodeficiência Adquirida, e tem sua origem no HIV (human imunodeficiency vírus ou vírus da imunodeficiência humana). Neste trabalho usaremos a sigla AIDS.
} 
I

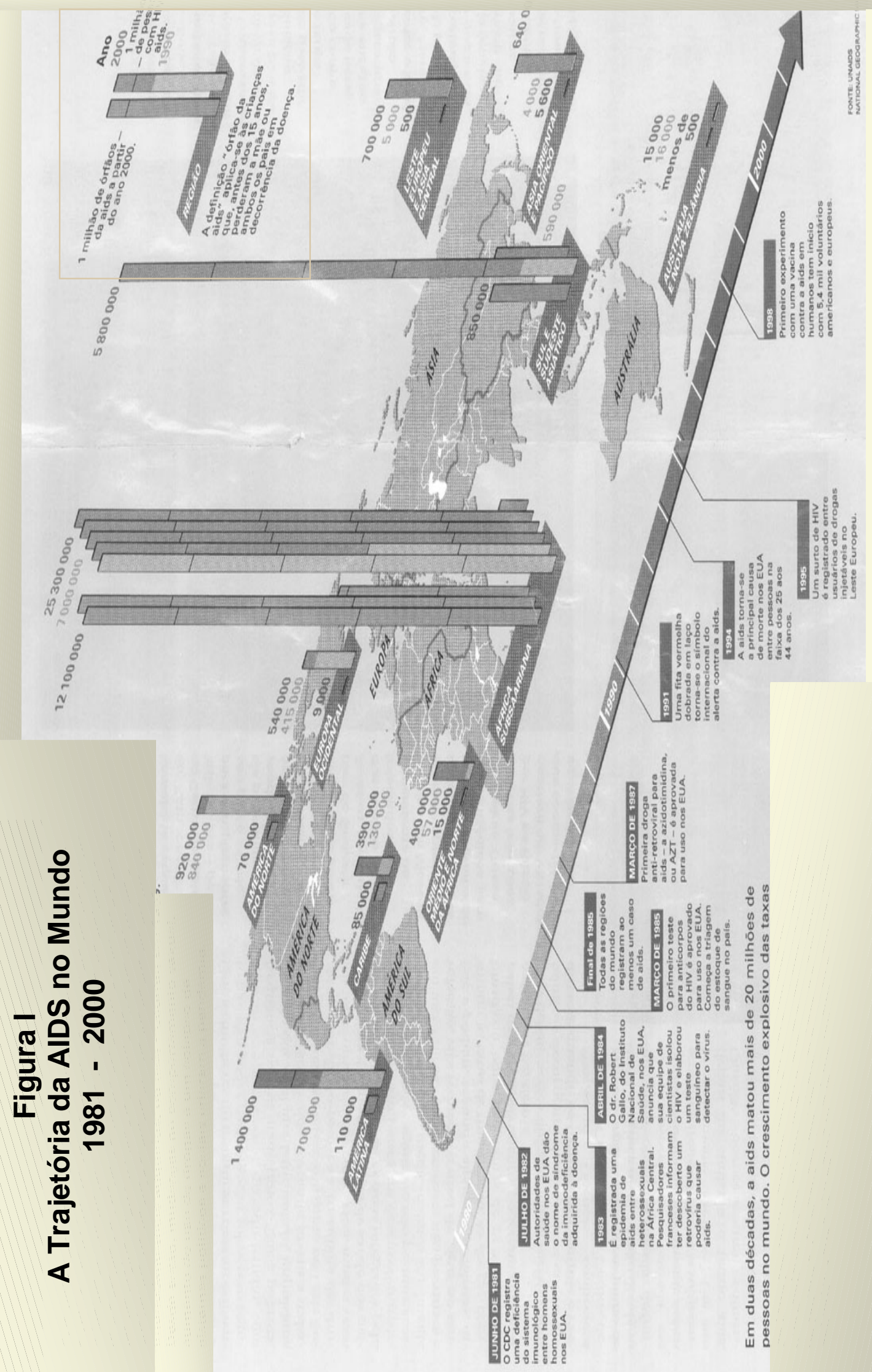


da AIDS, implicando na discriminação, estigma, preconceito e exclusão do indivíduo contaminado. É a recriminação ao sujeito que se comportou fora do recomendável, que transgrediu as normas do prazer e do uso do sexo, da utilização de drogas.

Não tardou muito a aparecer os discursos procedentes de outros campos do conhecimento, pois, segundo Carneiro (2000, p.82), "se aparece um vazio na prática explicativa que o saber médico não pode preencher, a Igreja ganha espaço (...)”. O pecado, objeto privilegiado dos discursos religiosos, ganha com a AIDS uma punição exemplar e publicamente manifesta. A Igreja Cristã, principalmente, ganha espaço reforçando as convicções das relações matrimoniais exclusivas como a única forma de proteção.

Em seguida, passa-se a utilizar a expressão comportamento de risco, cujo objetivo era retirar o peso do estigma dos grupos; entretanto, Ayres (1998) afirma que este conceito também fracassa, pois tende a acentuar a culpabilização individual, ou seja, quanto mais o comportamento se afasta do modelo tradicional, maior o suposto risco do contágio.

Contudo, os discursos médico e religioso identificam a figura do indivíduo que contraiu a enfermidade de forma involuntária, o hemofílico. Para ele é dispensado um tratamento moral, enquanto para os outros são atribuídas pesadas cargas morais. Assim, conforme Carneiro (2000), mais uma representação vem somar-se às outras: a do doente inocente e doente culpado, dando um duplo sentido à palavra pena. De um lado, se dirige aos que feriram as normas sociais, médicas e religiosas, significando um castigo imposto; de outro, aos que foram contaminados involuntariamente, quando, então, significa compaixão. Assim, saber a forma do contágio pelo HIV implica o tipo de sentimento dirigido ao doente (Carneiro, 2000; 
Paulilo, 1999).

Em 1993, Jonatham Mann chamava atenção para o fato da ocorrência de várias epidemias em paralelo com "a epidemia" de AIDS, acometendo diversos segmentos da sociedade, com padrões de disseminação e velocidade variados, configurando, portanto, diferentes vulnerabilidades à infecção pelo HIV. A AIDS deixava de ser uma doença de segmentos populacionais sob particular risco, podendo ter sua disseminação na população em geral, embora com particularidades distintas. Surge assim, o conceito de vulnerabilidade, ampliando as tradicionais categorias de análise epidemiológica, incorporando dimensões culturais, sociais e políticas. Para Ayres et al. (1999), a importância do conceito de vulnerabilidade está em considerar a possibilidade da exposição das pessoas ao adoecimento como resultante de aspectos não apenas individuais, mas também coletivos e contextuais que acarretam maior susceptibilidade à infecção.

Em outras palavras, pode-se afirmar que ser vulnerável significa não ter meios para se proteger; não ter acesso aos cuidados com a saúde, à educação, trabalho; fonte de renda, moradia. É também não ter liberdade para escolher ou propor. O conceito de vulnerabilidade ajuda a entender melhor a relação crítica entre discriminação social e risco para o HIV; discriminação que é resultante de condições sócio-econômicas e culturais. De acordo com Ayres et al (1999) conceito de vulnerabilidade busca estabelecer uma síntese conceitual e prática das dimensões político-institucionais e comportamentos, associada às diferentes suscetibilidades de indivíduos, grupos populacionais e, até mesmo, reações à infecção pelo HIV e às suas conseqüências indesejáveis (doença e morte). Ao fazê-lo, não visa distinguir

"a probabilidade de um indivíduo qualquer se expor à AIDS, mas busca 
fornecer elementos para avaliar objetivamente as diferentes chances que cada sujeito ou grupo populacional particular tem de se contaminar, dado o conjunto formado por certas características individuais e sociais de seu cotidiano, julgadas relevantes para a maior exposição ou menor chance de proteção diante do problema" (pág. 24).

$\mathrm{O}$ processo de vulnerabilidade social traz à tona as assimetrias sociais, tornando as pessoas com menor nível de escolarização, inseridas em ocupações malremuneradas ou fora do mercado de trabalho e, portanto, com acesso restrito aos cuidados com a saúde, cada vez mais expostas à infecção pelo HIV.

No Brasil, conforme ressaltado por Betinho ${ }^{2}$, a AIDS chegou antes da AIDS, constituindo-se este fato em importante dimensão a ser compreendida para analisar a história social da doença. Galvão (2000), ao traçar a agenda da epidemia de AIDS no Brasil, destaca a importância da mídia na forma como a AIDS chegou ao Brasil: “não será pelos casos de pessoas com AIDS notificados no país, mas pelo relato da doença via a mídia. (...) a nova enfermidade de forma conhecida e popular antes que os casos de AIDS fossem oficialmente reportados" (p. 48). Assim, a AIDS foi associada aos homossexuais pertencentes à classe média culta, intelectual, artistas, membros de grupos sociais próximos da mídia e dos quais esta costuma falar. Ainda em relação ao papel da mídia na forma como a AIDS foi representada nos anos iniciais, Herzlieh e Pierret (1992) observam que através da mídia, “a doença tornouse objeto de tomada de posição, de enfrentamentos, de clivagens coletivas” (p.09).

O primeiro caso de AIDS no Brasil foi notificado, retrospectivamente, na cidade de São Paulo, em 1980 (Ministério da Saúde, 1999), seguido de outros casos, basicamente restrito às grandes cidades brasileiras - São Paulo e Rio de Janeiro,

\footnotetext{
${ }^{2}$ Essa afirmação era constante nos discursos de Herbert de Souza, o Betinho, sociólogo, contaminado pelo HIV através de transfusão de sangue, criador da Ação da Cidadania contra a Miséria e pela Vida e fundador da ABIA-Associação Brasileira Interdisciplinar da Aids.
} 
tendo como categorias de exposição, preponderantemente, os homossexuais masculinos, os hemofílicos e demais pessoas que receberam sangue e hemoderivados. Em seguida, em meados da década de 80, outro segmento populacional se destacou, constituído por usuários de drogas injetáveis (UDI). Entretanto, à extensa disseminação inicial, seguiu-se uma certa estabilização em anos posteriores, especialmente, entre as camadas médias urbanas, na qual verificou-se relevante mobilização social e mudanças de comportamentos (Bastos et al. 1995; Parker, 1994; Szwarcwaltz et al., 2000).

No entanto, conforme ressalta Bastos (2000), o impacto marcante da epidemia sobre os homossexuais e outros segmentos populacionais, objetos de estigma, despertou preconceitos homofóbicos que dificultaram a recepção de leituras alternativas da epidemia, que não as que se referissem aos então chamados grupos de risco. Como exemplo, este autor cita as pesquisas de Klovdal que, já em 1985, afirmava que a epidemia, além da dimensão exclusivamente comportamental, progrediria através de redes sociais de maior vulnerabilidade social.

Assim, no Brasil, um país caracterizado por diferenças geográficas e desigualdades sociais, a epidemia de AIDS passa, atualmente, a ser determinada pelos processos de interiorização, pauperização, heterossexualização e feminização (Szwarcwald et al., 2000; Bastos et al, 2000; Parker \& Camargo Jr. 2000).

Embora a incidência em termos absolutos de casos de AIDS ainda traga as grandes cidades brasileiras no topo da lista, se observarmos a incidência proporcional com relação ao número de habitantes, torna-se claro uma tendência à interiorização da epidemia (Quadro 1). Segundo Parker \& Camargo Jr (2000), este processo se deve principalmente às rotas de distribuição e consumo de drogas entre cidades como, por 
exemplo, Santos, Itajaí e entre cidades que compõem a chamada rota caipira, como Campinas e Ribeirão Preto.

Quadro 1 - Cidades com os 10 maiores coeficientes de incidência de casos de AIDS notificados (por 100000 hab) - 1991-2000

\begin{tabular}{|lc|}
\hline \multicolumn{1}{|c|}{ Cidade } & Coeficiente de Incidência \\
\hline 01 - Itajaí (SC) & 866,2 \\
02 - Santos (SP) & 732,5 \\
03 - Florianópolis (SC) & 683,3 \\
04 - Ribeirão Preto (SP) & 629,9 \\
05 - Balneário Camboriú (SC) & 617,0 \\
06 - Caçapava (SP) & 603,4 \\
07 - São José do Rio Preto (SP) & 589,6 \\
08 - Porto Alegre (RS) & 538,7 \\
09 - Barretos (SP) & 518,7 \\
10 - Bebedouro (SP) & 510,6 \\
\hline
\end{tabular}

Fonte: Boletim Epidemiológico - CNDST/AIDS, 2001

O consumo de drogas constitui o único hábito/comportamento relacionado ao risco da infecção pelo HIV que não é objeto só de estigmas, mas também de criminalização, determinando problemas adicionais, principalmente entre os estratos sociais menos favorecidos. Este fator tem influência relevante na rede de disseminação da epidemia, principalmente na medida em que são, de acordo com estudos realizados (Bastos \& Szwarcwald, 2000), em sua maioria, homens, jovens, sexualmente ativos e com uso assistemático de preservativo, desempenhando papel relevante na disseminação subseqüiente da infecção para suas companheiras, UDI ou não.

Entretanto, se o perfil inicial da epidemia corresponde a indivíduos índice de 
escolaridade $^{3}$, o aumento do registro de casos demonstra uma tendência ao acometimento de indivíduos com menor grau de instrução, o que pode ser com alto considerado um indicativo da propagação da epidemia em direção aos segmentos mais desfavorecidos da sociedade, ou seja, a pauperização da epidemia conforme pode ser observado no Gráfico 1.

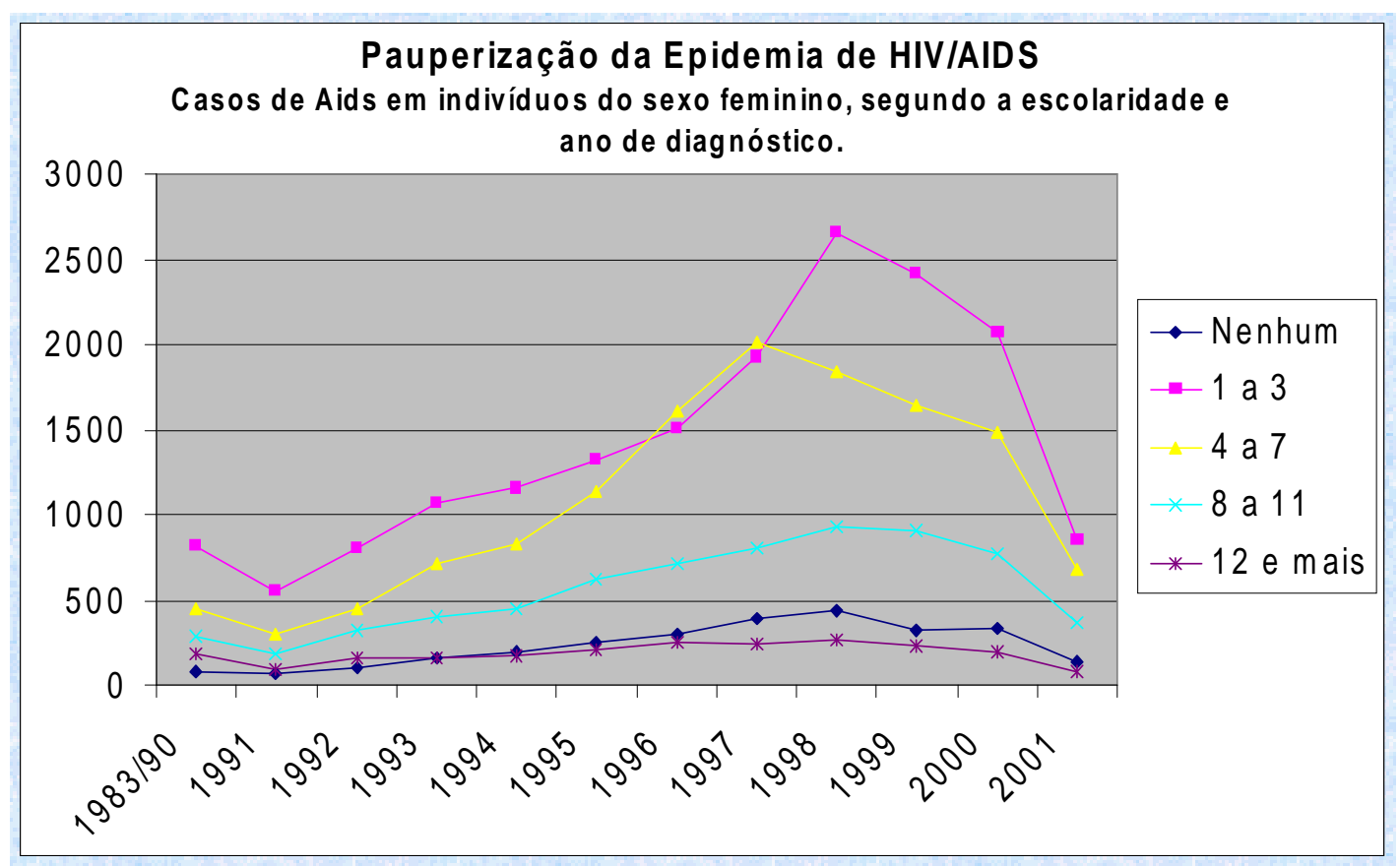

Pela tendência observada no Brasil, de acordo com Castilho\&Chequer (1997),

“as populações já tradicionalmente marginalizadas, sobre as quais recaem a grande maioria das doenças endêmicas, as patologias decorrentes da fome e ausência de saneamento, vêm cada vez mais se infectando com o HIV. Como fator agravante adicional ressalte-se o fato das dificuldades naturais que enfrenta esta camada social no que se refere ao acesso aos serviços de saúde e a informação de um modo geral e a informação para a saúde de um modo particular. Este último aspecto, somado às prioridades impostas pela

\footnotetext{
${ }^{3} \mathrm{O}$ instrumento de coleta de dados adotado pelo Ministério da Saúde não dispõe de variáveis outras que mensurem o nível sócio-econômico, sendo a escolaridade a única informação disponível, portanto, será tomada aqui como indicador do estrato social.
} 
necessidade e voltadas para a sobrevivência do dia-a-dia, dificultam sobremodo as ações que visem à prevenção" (p.24).

Outro aspecto demonstrado pelos indicadores epidemiológicos diz respeito ao padrão de transmissão sexual da AIDS. O aumento do número de casos entre os heterossexuais fez-se acompanhar de um expressivo aumento do número de casos de mulheres no quadro epidemiológico, conforme pode ser observado no Gráfico 3, e também constatado na razão por sexo, que passou de 28:1 em 1985, para 3:1 em 1997, estando atualmente em 2:1 (MS - CNDST/AIDS $\left.{ }^{4}, 2001\right)$.

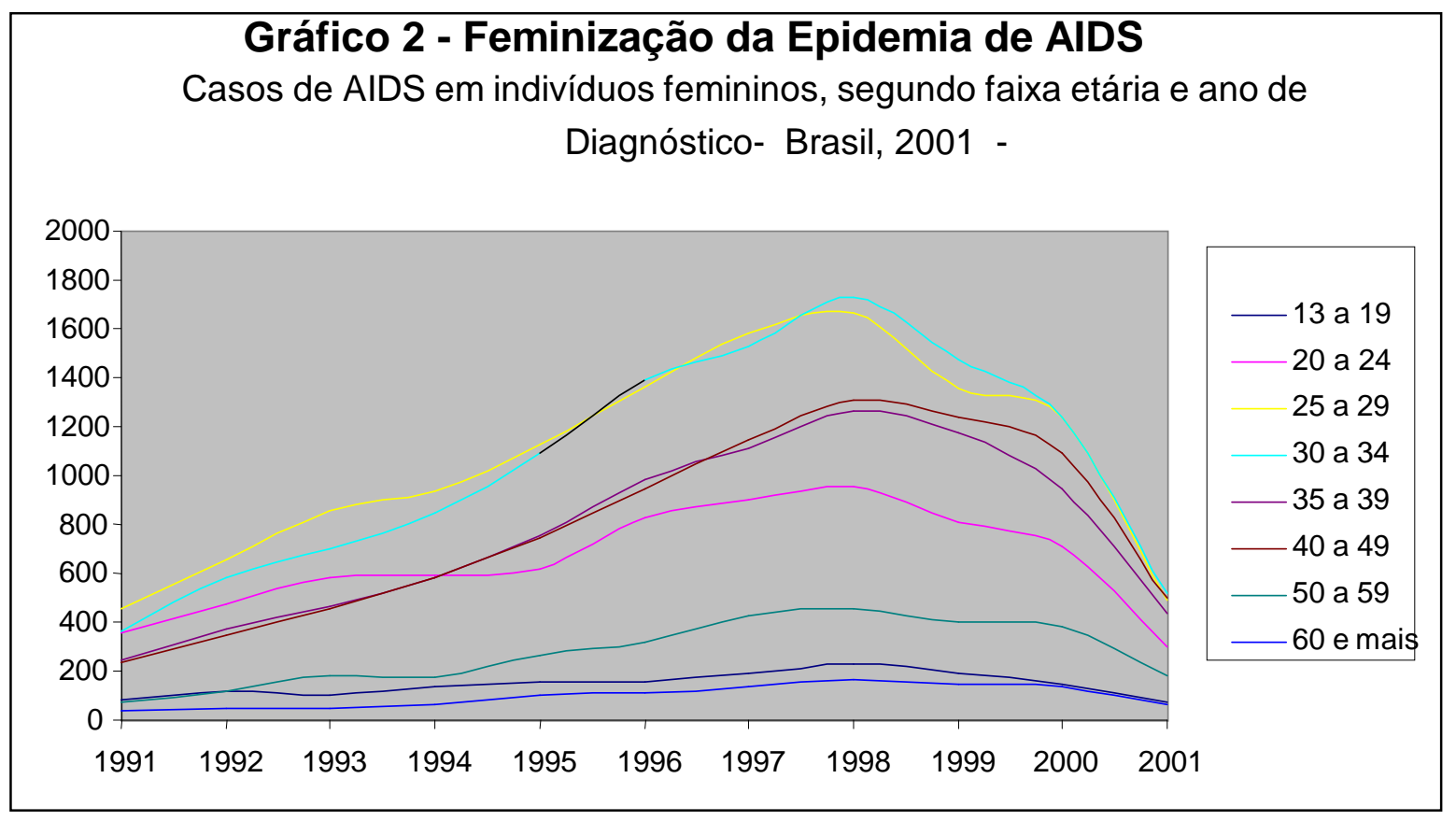

Fonte: Boletim Epidemiológico - CNDST/AIDS, 2001

Conseqüentemente, o aumento da ocorrência de casos do sexo feminino em idade reprodutiva, visto que o grupo de mulheres entre 25 e 35 anos tem sido o mais atingido, reflete em crescimento efetivo de casos de transmissão perinatal.

\footnotetext{
${ }^{4}$ Coordenação Nacional das Doenças Sexualmente Transmissíveis e AIDS
} 
O avanço do HIV/AIDS entre as mulheres é indicativo não apenas das dificuldades para oferecer respostas institucionais para a contenção da epidemia, mas também, e sobretudo, remete para as questões que envolvem a identidade de gênero, que determinam os papeis sociais de homens e mulheres, cuja assimetria aumenta a vulnerabilidade das mulheres à infecção.

A infecção pelo HIV continuará atingindo todas as classes sociais, expandindo-se, porém, cada vez mais amplamente entre os indivíduos mais pobres. Dentre esses, as mulheres ocupam lugar de destaque, pois são elas as que menos condições têm de mudar as situações que as colocam em risco.

\subsection{1 - Fatores Estruturais da Disseminação do HIV/AIDS}

Com base nas inúmeras pesquisas realizadas na ultima década, Parker \& Camargo Jr. (2000) agruparam os fatores estruturais facilitadores da disseminação do HIV/AIDS em três categorias distintas, mas interconectadas:

1 - (Sub)desenvolvimento econômico e pobreza;

2 - Mobilidade, incluindo migração e trabalho sazonal;

3 - Desigualdade de Gênero.

Para estes autores, os complexos processos de globalização e de reestruturação da economia mundial, característicos das décadas finais do século XX, iniciada na década de 70 , bem como a série de transformações subseqüentes nas estruturas das sociedades, comunidades e famílias, são, talvez, os fatores relativos mais importantes a ser buscado no entendimento da evolução global da epidemia do 
HIV/AIDS.

Castells (1999), cita a passagem do regime Keynesiano-Fordista do capitalismo industrial para o que denominou capitalismo informacional, como modo dominante de desenvolvimento neste final de século, caracterizado pela substituição dos tradicionais materiais brutos da produção industrial, pelo controle sobre o processamento de informação como característica-chave da produção e acumulação capitalista globais, tornando possível funcionar como unidade única, trabalhando e interagindo em tempo real, ou seja, a chamada globalização.

Entretanto, se este conjunto de transformações tem proporcionado a conexão entre as elites ao redor do mundo, ao mesmo tempo surgem novas formas de exclusão social e extremos de desigualdade, diferenciais de renda, pobreza e miséria.

Essa fase recente de globalização, segundo Castell (1999), tem se caracterizado, portanto, pela acentuação dos processos de diferenciação social, por um lado, e por relações de distribuição e consumo, por outro. A organização social da diferenciação ou desigualdade na distribuição tem sido polarizada entre ricos e pobres, com os setores intermediários - a classe média - gradativamente desaparecendo, associada ao aumento da miséria. Ao mesmo tempo, a diferenciação social nas relações de produção tem se caracterizado pela crescente individualização do trabalho (decadência dos sindicatos e crescimento do setor informal); a superexploração dos trabalhadores (crescimento do trabalho infantil; a crescente exclusão de grupos do mercado de trabalho; da mesma forma que a integração perversa destes mesmos setores no mundo paralelo da economia criminosa).

Estas tendências básicas, segundo Parker \& Camargo (2000) também foram 
identificadas ao que poderia ser descrito como progressiva feminização da pobreza e miséria, referindo-se ao fato de que, embora as mulheres tenham sido incorporadas ao mercado formal de trabalho, as que vivem em situação de pobreza tornam-se cada vez mais excluídas, não apenas devido à opressão baseada em classe, mas também à opressão baseada em gênero. Tais transformações têm impactado desproporcionalmente a vida das mulheres, acentuando a feminização da pobreza e da miséria mesmo em meio a uma série de ganhos importantes em termos do feminismo e da conquistas de direitos civis e políticos adicionais.

O processo de desenvolvimento econômico cria, com freqüência, formas de deslocamento social - segundo fator citado - aos quais, por seu turno, produzem ações e práticas sociais que aumentam o risco de infecção pelo HIV. Como exemplo, pode-se citar pesquisas com trabalhadores sazonais (Romero-Daza \& Himmelgreen, 1998); trabalhadoras do sexo e homens que fazem sexo com homens no Brasil (Larvie, 1997; Parker, 1997).

Os fatores políticos econômicos que impulsionaram a epidemia de HIV/AIDS estão também intimamente ligados à organização social das estruturas de gênero e sexualidade, cujas hierarquias fazem das mulheres - em especial àquelas dos segmentos de baixa renda - extremamente vulneráveis à infecção pelo HIV.

O Brasil pode ser visto como uma complexa síntese onde estão virtualmente presentes todos os diferentes fatores sócio-economicos identificados como estruturantes da vulnerabilidade relacionada ao HIV/AIDS. De acordo com Parker \& Camargo Jr. (2000), formas variadas de desigualdade e opressão, em conjunto com a variada gama de fatores estruturais e ambientais, combinam-se no território brasileiro para produzir e reproduzir forças sociais que foram identificadas, em âmbito 
internacional, como motores da epidemia: os movimentos migratórios, a falta de poder das mulheres sujeitas simultaneamente à opressão e econômica e de gênero, o encolhimento do mercado formal de trabalho e a desintegração social produzida pelo crime organizado e o tráfico de drogas.

\subsection{2 - Fatores Estruturais da Feminização da Epidemia no Brasil}

Conforme análise de Bezerra Jr. (2000), o Brasil

"é uma das mais poderosas economias e está entre os países de menor "desenvolvimento humano". Seu desempenho em termos distributivos é um dos piores do planeta. Sua concentração de renda é vergonhosa, assim como os índices de doenças da miséria, como a hanseníase, esquistossomose, malária, chagas e tuberculose. Único país do mundo com uma extensão territorial tão imensa e com uma única língua e cultura, cultiva, entretanto, desigualdades sociais e regionais tão brutais que impõem verdadeiras fronteiras internas. Não tivemos o racismo como ideologia oficial, mas ostentamos um verdadeiro apartheid social. Não temos entre nós a pulverização de etnias, nações ou comunidades lingüísticas ou religiosas que acendem fogueiras em tantos pontos do mundo. No entanto, abismos econômico-sociais dividem parcelas da população, como se houvesse de fato mais de um país no mesmo território" (p.47).

Sendo assim, o aumento da desigualdade, da exploração do trabalho, da marginalidade e da miséria, crescente descompasso entre as capacidades de produzir e de consumir, irracionalidade crescente do conteúdo da oferta com relação às necessidades básicas da maior parte da humanidade, são características que, de acordo com Plastino (2000), ilustram a situação vigente no terreno da economia brasileira. Consequientemente, a sociedade do individualismo tem-se tornado também a sociedade da solidão, da intolerância e da xenofobia.

Soma-se ainda o fato de que, historicamente, uma das reações mais comuns tem sido atribuir a responsabilidade da doença ao próprio doente, associando hábitos 
e costumes considerados desregrados de determinados grupos à doença, gerando, imediatamente, a idéia já tão combatida de grupos de risco, que seriam os responsáveis diretos pela proliferação dos agravos. Foi assim que, o que se pensava estar concentrado em um grupo específico, com condições de arcar com seu próprio tratamento, desvenda seu perfil e, rapidamente, cresce entre os segmentos mais empobrecidos e vulneráveis da população. Seguindo este perfil, a epidemia em curso no Brasil vem afetando, de maneira crescente, mulheres pertencentes aos estratos mais pobres, em sua maioria donas de casa, que tem como parceiro sexual seu marido.

Buscando analisar os determinantes estruturais da feminização da epidemia de AIDS no Brasil, considerando os efeitos da interação entre desigualdades sociais e de gênero, Bastos (2000) encontrou, além dos fatores gerais, os pontos de maior vulnerabilidade feminina conforme sistematizados na Figura II.

De acordo com este estudo, a mulher torna-se mais vulnerável do ponto de vista biológico devido à extensão da superfície da mucosa vaginal exposta ao sêmen, que têm uma concentração de HIV (livre e no interior da célula) significativamente maior do que o líquido vaginal, além da direcionalidade do sêmen, que é ejaculado, enquanto o líquido vaginal se difunde por espalhamento.

Além disso, é amplamente reconhecida a relação existente entre a Aids e as outras doenças sexualmente transmissíveis (DST) - ou Infecções Sexualmente Transmissíveis (IST), como prefere o autor - sendo estas, facilitadoras para a infecção pelo HIV, determinando uma fragilização das barreiras naturais à infecção. Nas mulheres, as IST são freqüentemente assintomáticas, dificultando sua detecção e tratamento. 
Todos estes riscos ampliados tornam-se ainda maiores ao se tratar de mulheres jovens e adolescentes, onde a imaturidade do aparelho genital determina uma fragilização adicional.

\section{Figura II - Determinantes Estruturais da Feminização da Epidemia de HIV/Aids.}

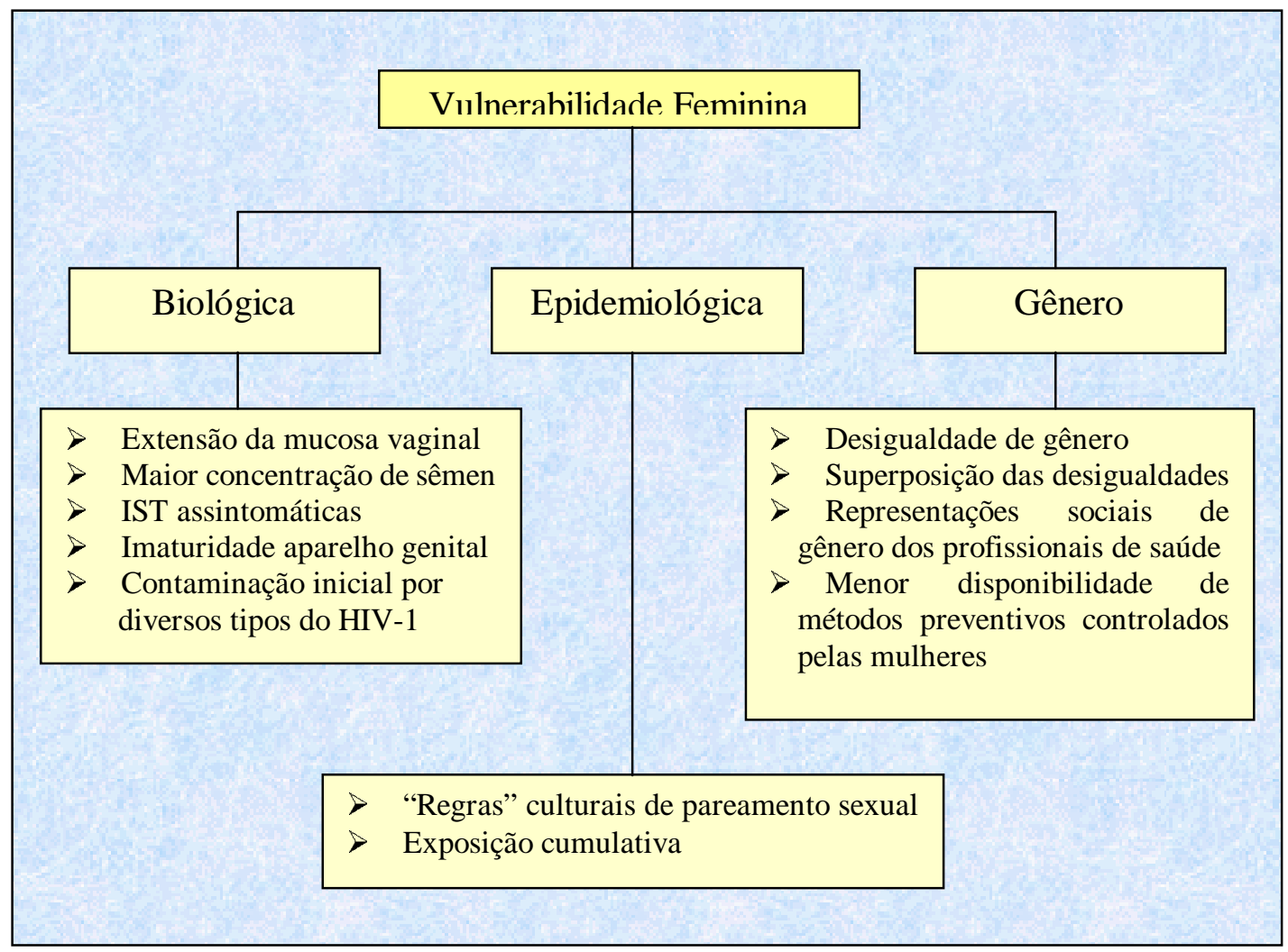

Foi evidenciado, mais recentemente, que as mulheres estariam mais suscetíveis à infecção, simultaneamente, por diversas quase-espécies do HIV-1, o que dificultaria a reação do sistema imunológico à infecção e facilitaria a emergência de variantes resistentes ao tratamento e de maior patogenicidade, ao contrário dos homens, onde ocorre maior homogeneidade das quase-espécies infectantes (Bastos, ibid). 
Epidemiológicamente, o autor ressalta as regras de pareamento vigentes na maioria das sociedades, que fazem com que mulheres jovens mantenham relações sexuais e estabeleçam parceria com homens mais velhos. Com isso, coortes etários mais jovens de mulheres estão sob risco ampliado de se infectarem pelo HIV (e IST) ao fazerem sexo desprotegido com um pool de homens mais velhos, onde os níveis de prevalência para o HIV e IST são mais elevados.

A exposição cumulativa por longos períodos de tempo é fundamental na determinação de níveis elevados de soroprevalência para a infecção pelo HIV, o que, além das repercussões diretas sobre a população feminina, determina epidemia mais extensa e dilatada no tempo, se comparada ao pareamento simétrico

Entretanto, Bastos (2000) ressalta como ponto central da questão da feminização da epidemia de HIV/AIDS, a questão de gênero. O tratamento desigual dado aos gêneros, em termos políticos, culturais e sócio-econômico têm uma dimensão macro e micro-social, compreendendo a não observância dos direitos fundamentais, relações desiguais de poder e acesso diferenciado a bens materiais e simbólicos, tendo lugar nas famílias e parcerias, como também na sociedade, organizadas em sistemas de crenças e códigos de valores.

Freqüentemente estas desigualdades se superpõem, gerando efeitos sinérgicos, que multiplicam os riscos a que estão submetidas as mulheres. A combinação da violência material e simbólica, da dupla moral no que diz respeito ao comportamento sexual de homens e mulheres no âmbito da família e da sociedade, da assimetria na capacidade de tomar decisões e efetivá-las, e a ausência de canais por onde manifestar queixas e resolver pendências (por diálogo ou via legal), torna mais difícil para a mulher ter acesso à informações adequadas e atualizadas. E, uma 
vez dispondo delas, modificar seus comportamentos e manter estas mudanças nas interações cotidianas.

Outro ponto de vulnerabilidade levantado nesta pesquisa, provém das representações sociais de gênero que permeiam o imaginário dos profissionais de saúde, cujas funções seriam também de identificar, notificar e aconselhar parceiros de casos-índice; orientar tratamento para as IST de forma conjunta para o casal; além de aconselhar indivíduos e casais a adotarem, de forma consistente, práticas sexuais mais seguras. No entanto, segundo este autor, estudos recentes demonstram que estas notificações e aconselhamento freqüentemente não são feitos de forma adequada do ponto de vista científico e da perspectiva de uma cultura que não se queira sexista e paternalista, incidindo estas inadequações e impropriedades, preferencialmente, sobre mulheres de classes sociais mais pobres, que são infantilizadas por orientações parciais e errôneos, não se beneficiando, como deveriam, de práticas que poderiam, ao menos em parte, compensar a maior vulnerabilidade desta população.

E, finalmente, a pouca disponibilidade de métodos preventivos controlados por mulheres, que, aliado à assimetria do poder de decisão nas relações afetivosexuais, e às taxas crescentes de esterilização feminina, principalmente entre mulheres mais pobres e jovens, provoca a disjunção entre as medidas anticoncepcionais e de prevenção das IST/AIDS, tornando ainda mais complexo o processo de prevenção.

Nas páginas que se seguem será abordado a vulnerabilidade feminina na perspectiva de gênero, a partir da hipótese de que as representações são conceitos historicamente condicionados - e não necessariamente determinados - admitindo-se a existência de uma relação dialética entre ideologia e as instâncias econômica, 
política e social.

\section{2 - Desigualdade de Gênero: uma herança histórica}

\subsection{1 - Organização Social, Gênero e Saúde}

De acordo com Fischer e Marques (2001), as relações entre homens e mulheres, ao longo dos séculos, mantém assimilações bipolarizadas, sendo designada às mulheres uma condição inferior reproduzida em todas as esferas de poder da sociedade. Platão, em "A Republica" (V livro), desenhava a mulher como a reencarnação dos homens covardes e injustos. Aristóteles, em "A História Animalium", afirmava que a mulher é fêmea em virtude de certas características: é mais vulnerável à piedade, chora com mais facilidade, é mais afeita a injúria, tem menos pudor e menos inibição. Os ideólogos burgueses destacaram sua inclinação natural para o lar e a educação das crianças. Rosseau vê a mulher como destinada ao casamento e à maternidade. Kant a considera pouco dotada intelectualmente, caprichosa, indiscreta e moralmente fraca. Encontramos ainda em Freud a afirmação “... a psicologia é incapaz de solucionar o enigma da feminilidade”(1977, p.144). Assim, aprendemos a ver um mundo dividido entre os aspectos masculinos e femininos, num tipo de cisão hierarquizada - em que o masculino predomina sobre o feminino - e que julgamos natural.

Buscar as raízes históricas ${ }^{5}$ da desigualdade de gênero, analisando-as numa perspectiva dialética do sistema formador, tendo em vista seus condicionantes superestruturais é o objetivo deste tópico.

\footnotetext{
${ }^{5}$ Pretende-se uma discussão simplificada, que deixará de lado numerosos aspectos, colocando em relevo apenas o que for de particular interesse nesta tese.
} 
As ações de saúde e a formação de recursos humanos nesta área também serão ancorados no processo histórico, sendo tratados como fenômenos sociais que se desenvolvem no contexto das ações humanas. Sendo assim, a necessidade de reflexões sobre o papel do sistema formador, torna-se essencial para a compreensão da realidade contemporânea.

\section{- Do Primitivismo à Racionalidade}

Nas sociedades primitivas, a terra era possuída comunalmente, a herança era repassada através das mães e o trabalho das mulheres tinha o mesmo valor que o dos homens.

O conhecimento e as práticas de saúde eram instintivas e o trabalho individual e não-sistemático visava apenas a satisfação das necessidades de sobrevivência. De acordo com Engels apud Nye, (1995), as clãs primitivas viviam em estado de anomia grupal (referente a falta de liderança e inexistência de regras estabelecidas). Os casamentos eram grupais, sendo os filhos considerados de todos os adultos.

Na medida em que os grupos humanos deixaram de ser nômades, desenvolveu-se uma cultura grupal, com atividades agrícolas e pastoris. Surge o excedente, e ao valor de uso, associa-se o valor da troca e, com isso, ocorre uma grande transformação nas relações sociais da época. Com a necessidade da produção em maior quantidade, visando o comércio, surge a necessidade de maior expansão de terras e maior força de trabalho. Culturas menos desenvolvidas passaram a trocar seus serviços por comida e abrigo. Surgem, assim, as relações de dominância e submissão (Rezende, 1986). 
Estas alterações sociais, com a atenção do homem voltada ao cuidado com a produção, vão redefinir também o relacionamento entre homens e mulheres, dando inicio ao estabelecimento das divisões de tarefas de acordo com o gênero (Reis, 2002).

A propriedade privada, de acordo com Nye (1995), dá origem à família patriarcal. De acordo com esta autora, dado ao poder que esta propriedade confere aos homens que a possuem, dado ao fato de que os homens querem transferir essa propriedade aos seus filhos varões, o direito da mãe é derrotado. O casamento passa a ser baseado na propriedade e tem uma função social: assegurar aos homens, herdeiros indiscutivelmente legítimos. Esse propósito exige a fidelidade para a mulher e, como não há função social para a fidelidade do homem, esta não é necessária. Assim, o casamento passa a ter padrões diferentes para a conduta sexual feminina e masculina.

Esta é, para Engels (apud Nye, 1995), uma das contradições do casamento. Ele preserva, para os homens, a antiga liberdade sexual da sociedade matrilinear, na forma de prostituição e casos extra-conjugais, ou seja, para os homens o antigo casamento grupal ainda vigora.

Engels vai além ao afirmar que a superioridade masculina, configurada com a propriedade privada dos meios de produção tornando o trabalho do homem mais produtivo do que o da mulher - reduzido à privatização do lar - delineou a primeira divisão do trabalho: doméstico e público.

De uma forma ampla, pode-se dizer que a sociedade passa a ser dividida entre os executores e os organizadores.A elite pensante detinha os privilégios de classe 
hegemônica e “às massas de trabalhadores bastariam músculos sólidos, vontade escassa, estomago satisfeito e coração vazio.” (Ponce, apud Resende, 1986)

$\mathrm{Na}$ Antiguidade, segundo Rezende (1986), as doenças eram explicadas pela força do sobrenatural e o sacerdote era o intermediário que, utilizando alguns recursos como ervas, beberagens e medidas higiênicas, alcançavam pela intervenção da divindade, a prevenção, a cura ou a morte.

Os papirus Kahun e Ebers são os documentos médicos mais antigos de que se tem notícia. Em ambos se encontram descrições dos problemas de comportamento característicos ou próprios das mulheres. De acordo com eles, todo mal-estar não justificado por uma lesão visível na mulher era imputado a migrações uterinas, atribuídas a presença de um ser misterioso que habitava o corpo feminino. Os tratamentos que se propunham se realizavam através de fumigações de odor agradável sob a vulva e fumigações de odor desagradável na altura do nariz, no caso de útero elevado e procedimento inverso no caso do útero ter descido (Gordon, 2002; Fernández, 1994).

As práticas sociais de saúde também eram divididas por classes: os curadores, marcados pela divindade, gozavam de grande poder e autoridade, não se ocupando de ações simplificadas, que caberiam a seus ajudantes anônimos.

As relações mitológicas entre doenças e divindades vão invadir a Grécia, onde os sacerdotes encarregavam-se da essência dos rituais, detendo o saber-poder da cura; aos leigos cabiam as ações rituais e os filósofos detinham-se nas especulações teóricas dos problemas de saúde.

Com os antigos gregos, segundo Reis (2002), surge uma nova forma de 
pensar, abstrata, onde se alicerça a civilização ocidental moderna. $\mathrm{O}$ pensamento platônico vai propor como cidade ideal àquela que tem três classes distintas: os chefes, que deveriam ter sabedoria, coragem e prudência; os guardiões, que deveriam ter coragem e prudência; e o povo, a quem bastava a prudência. As massas trabalhadoras eram vistas por Platão como monstros de potenciais forças destrutivas, devendo ser atreladas às práticas, sem possibilidade de desenvolver o pensamento, como forma de mantê-lo sob controle e garantir a cidade justa.

Em Aristóteles, o homem é visto com um animal político por natureza habitante da polis, que é uma forma essencial de Estado. Como tal, detém a capacidade da cidadania, onde ser cidadão é privilégio de classe. Os cidadãos não poderiam exercer nenhum tipo de atividade - mercador, artesão, agricultor - pois seria contrário à sua virtude. Para a formação da virtude política seria necessário o ócio.

De acordo com Reis (2002), neste modelo de sistema social impera a primazia masculina em todas as instituições (governos, igreja, economia, educação, etc) e, principalmente na família. Assim, o patriarcado, que começou aos poucos com o desenvolvimento do comércio de trocas, confere aos homens o poder de controlar as especificidades de gênero que, ainda hoje vigoram.

No início da era Cristã, enquanto a religiosidade grega ainda atribuía as doenças e curas aos deuses, surge Hipócrates, considerado o maior divisor entre os conceitos de saúde místicos e ações sacerdotais, para a saúde enfocada como homeostase e a doença como desequilíbrio. Hipócrates enfatizava as ações climáticas e geográficas, os hábitos alimentares como provocadores de doenças. Considerava os sintomas e sinais manifestações das doenças. Distinguiu-se, 
principalmente, pelo sentido ético atribuído às ações de curar (Rezende, 1986).

Para a medicina hipocrática, baseada em uma teoria dos humores, a saúde dependia do equilíbrio entre os quatro humores do corpo humano: o sangue, a bílis, a água e a fleuma. Sendo assim, conforme relata Fernández (1994), se considerava importante a regularidade menstrual e a regularidade das relações sexuais como condição de equilíbrio feminino. Hipócrates manteve a teoria dos úteros migradores e seu tratamento, a que se referiam os papiros antigos. Eram as relações sexuais freqüentes - porém, não muito - que asseguravam ao útero sua tranqüilidade, portanto o casamento e a gravidez eram recomendados para as mulheres jovens, pois caso não fossem desvirginadas pouco antes da menarca, o sangue poderia não encontrar saída, levando a vários padecimentos, como angústia, visões, delírio, tendência ao suicídio, etc.

Além disso, eram assinaladas diferenças de órgãos entre homens e mulheres, esboçando-se o começo de uma hierarquização onde o próprio e específico das mulheres é inferior aos dos homens, e mais ainda, uma relação de dependência, já que uma mulher úmida, produtora de fluidos, dependia do homem para manter sua saúde.

Com Platão, ainda que conserve muito das noções anteriores, é outorgado à mulher um novo lugar na criação. Segundo o "Mito das Origens" (Fernández, 1994), o homem tem uma alma racional e imortal que se aloja na cabeça. Esta alma se compõe de duas partes, que são mortais: uma alojada no peito, que é uma alma irascível, que dá coragem, e outra alojada no ventre, lugar do desejo e da concupiscência, da lascívia. De acordo com este mito, as mulheres são homens castigados, ou seja, aqueles machos que foram covardes e, em um segundo 
nascimento, foram transformados em mulheres.

Aristóteles retomará as teorias platônicas, reafirmando o útero como órgão essencial da mulher e, junto com Platão, refutará a teoria hipocrática com respeito ao papel da mulher na procriação. Hipócrates sustentava que homens e mulheres tinham função igual na concepção. Afirmava que o prazer feminino no ato sexual era necessário para a fecundação, ainda que a mulher servisse apenas de recipiente do sêmen masculino. Tem início aqui um debate sobre o prazer feminino que perdurará por séculos.

Sintetizando, para o mundo antigo, o discurso médico consagra a inferioridade feminina como algo inerente a sua natureza e estabelecido por vontade divina, portanto, é necessária e não contingente sua inferioridade na ordem social. A enfermidade das mulheres, segundo os saberes médicos, é explicada pela teoria do útero migratório.

Na análise feita por Fernández (1994), em consonância com os discursos médicos sobre o feminino, circula o discurso filosófico sobre a diferença, onde é homologado o Homem como o homem e toda representação da mulher, se constitui como o diferente ${ }^{6}$. Sendo assim, os homens serão o ponto de medida, positividade, enquanto as mulheres serão negatividade, reverso, complemento.

\section{- Feudalismo: religião e bruxaria}

Com o enfraquecimento do Império Romano no Ocidente, surge um novo

\footnotetext{
6 “.... se produce uma homologación de lo genérico lo masculino, es decir, en tanto se homologa el Hombre con el hombre, toda representación de la mujer, se constituye como lo diferente, como Lo Otro" (Fernández, pag. 71).
} 
sistema social, o feudalismo, considerado por muitos historiadores como um retrocesso histórico, que vai vigorar durante a Idade Média - abrangendo desde o séc V até o séc. XV - cujas características básicas foram a economia agrária voltada para a subsistência, o trabalho servil do camponês, a sociedade hierarquizada, o poder político descentralizado nas mãos dos diversos senhores feudais e o grande poder da Igreja.

A sociedade feudal se dividia basicamente em senhores e servos. Os senhores pertenciam à nobreza guerreira ou ao clero. Os servos eram os camponeses que habitavam os feudos e trabalhavam a terra. Eram submetidos à autoridade dos senhores locais e lhes deviam uma série de obrigações: trabalho gratuito, parte do que produziam nas terras do feudo, taxas diversas pelo uso de equipamentos e instalações do feudo, dentre outros.

Esta sociedade era estamental. Não havia mobilidade social; a posição social era determinada pelo nascimento. Não havia casamento fora do estamento, dessa forma, estava descartada a possibilidade de ascensão social.

No aspecto ideológico, o feudalismo se caracterizou pela religiosidade. A Igreja Católica detinha o monopólio da religião e esta constituía o universo mental da sociedade medieval, explicando a realidade visível e invisível. Além de grande possuidora de terras, a principal fonte de riqueza da época, a Igreja controlava as manifestações culturais. O clero era o único grupo letrado e os poucos livros existentes pertenciam aos mosteiros e, mais tarde, às universidades, que também surgiram no seio da Igreja.

A Igreja desempenhava o importante papel de legitimar a ordem social 
existente, que, segundo o seu discurso, seria resultado da própria vontade divina. Assim, o clero teria a missão de ser intermediário entre Deus e os homens. Aos nobres caberia defender a sociedade e a religião. Os servos teriam a missão de trabalhar e garantir o sustento de todos.

A sociedade feudal, no que se refere às relações entre homem-mulher, tem caráter patriarcal. A mulher devia contribuir para a reprodução da espécie, submeterse às ordens do marido ou do pai e servir, para os arranjos políticos e econômicos entre famílias nobres, por meio do casamento. O homem tinha enfatizado suas virtudes guerreiras, a coragem, lealdade e bravura. A ele caberia lutar pela fé, em defesa do seu senhor e em honra da mulher.

As ações de saúde no período feudal, conforme enfatizado por Rezende (1986), eram predominantemente práticas caseiras, executadas por mulheres mais experientes a quem também cabiam os cuidados nos partos. As cirurgias eram praticadas por aqueles que manipulassem melhor os instrumentos. O cuidado com os doentes foi uma das primeiras tarefas que o cristianismo se propôs, entretanto estas práticas nos mosteiros retrocederam historicamente, com o desenvolvimento de crenças em poderes miraculosos de relíquias, amuletos, água-benta, óleos, esconjurações e exorcismo.

A sociedade medieval, devido a falta de recursos, foi palco de grandes doenças endêmicas, como a Lepra e a Peste Negra, que dizimaram grande parte da população européia. O desconhecimento em relação às doenças e suas origens, conforme relata Carneiro (2000), abriu espaço para todo tipo de especulações, sendo creditado como forma de castigo enviado pela ira divina como corretivo frente às ações perversas do homem. 
Estes doentes, acrescenta Rezende (1986), foram integrados, ao lado da loucura, num espaço moral de exclusão, sendo encaminhados aos chamados hospitais gerais, junto a todos que apresentassem comportamentos desviantes.

Em suma, a representação que a medicina da época tinha do sexo feminino é a de uma réplica imperfeita do gênero humano, que é o homem, tal como havia construído o mundo antigo.

No mundo cristão, onde unicamente o homem tem alma, somente ele é feito à imagem e semelhança de Deus. A mulher representará o instintivo, o irracional, o animal. Fernández (1994) acrescenta ainda que a mulher era concebida como sexo, e este como estigma, devendo, portanto, ficar sob controle dos homens. Em uma sociedade que valorizava a castidade para os homens, a mulher é uma permanente tentação. O desejo feminino, na imaginação dos homens castos do clero, alcança imensas proporções chegando a ser conceptualizada como demoníaca, situando as mulheres como objeto de permanente desconfiança, quando não de perseguição.

Os matrimônios tinham como função estabelecer alianças entre as famílias e assegurar a transmissão da herança. Casamentos por amor subvertiam a ordem social. A Igreja propunha a castidade para homens e mulheres, e as relações sexuais deviam evitar o prazer e cumprir exclusivamente com seus fins procriativos.

No marco de lutas religiosas e com uma representação do sexo feminino tão ameaçador, não é difícil imaginar que o confinamento e a destruição de mulheres serviu para expiar diversas situações de origem político, econômico, social e psicológico que atemorizavam à governantes e população.

Entretanto, as mulheres tipificadas como bruxas eram, em sua maioria, 
mulheres pobres, provenientes do meio rural, por fora do sistema de alianças matrimoniais e que tinham ao seu encargo a medicina dos setores populares. Eram mulheres que possuíam um certo saber e isto desafiava as bases do lugar que esta sociedade destinava às mulheres.

Muraro (1991), em sua "Breve Introdução Histórica", relata sobre as conseqüências deste período:

"Quando cessou a caça às bruxas, houve grande transformação na condição feminina. A sexualidade se normatiza e as mulheres se tornam frígidas, pois orgasmo era coisa do Diabo e, portanto, passível de punição.Reduzem-se exclusivamente ao âmbito doméstico, pois sua ambição também era passível de castigo. $O$ saber feminino cai na clandestinidade, quando não é assimilado como próprio pelo saber médico masculino, já solidificado. As mulheres já não têm mais acesso ao estudo como na Idade Média e passam a transmitir 'voluntariamente' aos seus filhos valores patriarcais, já então totalmente introjetados por elas. E, com a caça às bruxas, se normatiza o comportamento de homens e mulheres europeus, tanto na área pública como no domínio do privado. E assim se passam os séculos. A sociedade de classes, que já está construída nos fins do século XVIII, é composta de trabalhadores dóceis que não questionam o sistema” (p. 16-17).

\section{- Renascimento: “o século das luzes"}

A partir dos séculos XII e XIII, com a escassez dos recursos de mão-de-obra, cada vez mais, os senhores asseguravam o serviço dos homens pagando-os em dinheiro, ao mesmo tempo em que aumentava a procura por administradores que soubessem ler e fazer contas. Para suprir esta demanda, foram fundadas escolas por toda a Europa.

O Renascimento traz consigo varias transformações sociais: a freqüência da alta burguesia às universidade, enquanto a pequena burguesia procurava escolas primárias;as traduções das obras hipocráticas, as determinações dos concílios na fundação das escolas e o estabelecimento do dever de cuidar dos doentes, 
principalmente por instituições femininas.

Nesta mesma época, a crescente população levou a uma grande expansão na quantidade e tamanho das cidades (burgos), muitas delas funcionando como mercados locais. As cidades se desenvolveram em pontos estratégicos: na confluência de rios, nos entroncamentos dos caminhos, nos portos marítimos, em torno dos castelos, mosteiros e Igrejas. O crescimento do comércio das cidades foi acompanhada pela expansão das atividades artesanais. Comerciantes e artesões, visando sua proteção, se organizaram em corporações e associações, chegando a desenvolver um sistema sofisticado de financiamento a credito, denominado usura.

Com o progresso nas diversas áreas, no final da Idade Média, vão se organizar três tipos de assistência de saúde: para os poderosos, que eram cuidados por médicos formados nas universidades e que recebiam honorários polpudos; para os artesões e burgueses, atendidos por médicos e cirurgiões com boa formação técnica, pelo qual recebiam boa remuneração; e para os pobres, cuja assistência ficava à cargo dos curandeiros, podendo tais doentes se refugiar e morrer em hospitais mantidos pela caridade municipal (Rezende, 1986).

Durante o Renascimento, se manteve a imagem de mulher que o clero havia sustentado através da Bíblia, na figura de Eva.Sempre inferior e maldita, simples fragmento do corpo viril, foi criada depois de Adão para ser sua companheira e não o inverso. Maldita porque conduziu Adão ao pecado original que pesará no Juízo Final sobre a humanidade.

Segundo Fernández (1994), o mais relevante da medicina da época com respeito à mulher foi a discussão sobre o lugar da mulher na concepção. A partir da 
descoberta de Harvey, um médico inglês, em 1650, de que todo embrião se desenvolve em um ovo produzido pela mulher, que será fecundado pelo sêmen masculino, demonstrando que ambos são indispensáveis e atuam de forma complementar (Gordon, 2002). Estas revelações produziram grande comoção e resistência até impor-se como verdade. O sexo feminino é, então, valorizado e tem início um extenso processo de veneração à maternidade.

É interessante observar que este fato trouxe mudanças também no culto à Virgem Maria. Na Idade Média, época do culto à castidade e rechaço à sexualidade, Maria era venerada por ser virgem. Para os cristãos do século XVII, já com clara influência dos discursos médicos - cada vez mais distanciados dos discursos religiosos - o culto mariano venera a maternidade e, conseqüentemente, a mulher adquire valor como indivíduo enquanto possível mãe. Esta reformulação da maternidade é acompanhada de um processo de medicalização do corpo da mulher.

A partir do reconhecimento de uma especificidade feminina - o papel da mulher na reprodução e a conseqüente valorização do feminino - vão sendo criadas as condições de possibilidade para a emergência do mito mulher $=$ útero, com um parcial afastamento do mito mulher $=$ homem inacabado que regeram a medicina desde os tempos clássicos até o século XIX.

Observa-se como os saberes médicos vão organizando sua racionalidade sem questionar a inferioridade feminina. $\mathrm{Na}$ realidade, esta crescente racionalização permitirá dar conta, através de explicações cada vez menos sobrenaturais, dessa inferioridade, descrevendo-a cada vez mais na ordem da biologia o que, um século mais tarde, produzirá o discurso da "natureza feminina". 
O discurso médico da "natureza feminina que vemos perfilar-se em anos anteriores vai consagrar, no século das "luzes", uma narrativa particular que delineará a imagem da mulher como frágil, emotiva, dependente, sexualmente passiva e predestinada à maternidade. Narrativa que ainda hoje mantém um grau relevante de produtividade e eficácia.

Além disso, em conseqüência de tal medicalização, se organizará uma particular relação entre as mulheres e seus médicos que culminará, no séc. XIX, com o surgimento do "médico de família" no lugar do confessor e, no século posterior, este espaço será ocupado pela psicanálise.

Porém, como ressalta Fernández (1994), esta mudança nas práticas médicas é parte de uma mudança estratégica dentro de um dispositivo mais amplo. A progressiva medicalização das mulheres faz parte de uma estratégia biopolítica pela qual, no cenário do capitalismo nascente, mentalidades e costumes vão girando a partir de um desperdício frente a uma economia dos corpos. Sem dúvida, este lugar de reconhecimento que a sociedade outorga à mulher enquanto mãe, vem acompanhada por um discurso que a significará como sexualmente passiva, afetivamente dependente e socialmente necessitada de proteção masculina.

As descobertas marítimas ampliavam o mercado, estimulando novos hábitos, assim como as estradas de ferro garantiam a circulação de produtos. Cada vez mais o comércio evidenciava-se como fator que gerava riquezas.

Entretanto, esta mobilidade social trouxe consigo, no final do séc. XV, uma nova epidemia. Inicialmente denominada de Mal de Nápoles devido ao seu surgimento com os soldados franceses em expedição pela Itália, a sífilis espalhou-se 
rapidamente por toda Europa, envolta numa núvem de acusações de sua origem sempre a uma nacionalidade estrangeira.

Em uma época que, conforme relata Carneiro (2000), as reformas religiosas imprimiram um discurso repressivo, situando a sífilis como um mal que circulava entre as pessoas condenadas socialmente por suas ações libertinas, estes doentes foram fortemente estigmatizados. A suspeita de que se tratava de uma doença sexualmente transmissível gerou inúmeras conseqüências sociais, como a perseguição à prostituição e o reforço do poder religioso através do sacramento do matrimonio e da influência crescente do clero sobre a educação e as famílias.

\section{- Capitalismo: nova ordem social}

Todas estas transformações sócio-econômicas já anunciavam a ordem social capitalista, que vai se consolidar ao final do séc. XVIII e inicio do séc. XIX. O capitalismo teve seu surgimento marcado pela concentração de capital (através do comércio) de um lado e, do outro, pela existência de uma classe trabalhadora e sem propriedade (expropriação da população camponesa).

Além disso, contribuíram também as reformas a que a Igreja estava submetida. Weber (apud Resende, 1986) destaca a teologia protestante como determinante de um modo de vida coerente com a prática capitalista. Enquanto a Igreja Católica Medieval preconizava como meio de salvação uma vida contemplativa, onde o trabalho e o enriquecimento eram vistos como desviantes do caminho da perfeição, o Calvinismo difunde uma ética onde o" homem seria apenas o administrador dos bens que Deus the haja conferido"(Catani, 1981:18, apud 
Rezende, 1986), indicando que a riqueza só seria condenável se constituir uma vadiagem ou aproveitamento pecaminoso da vida. Sendo assim, o trabalho passa a ser valorizado e só através dele Deus é glorificado.

Com a Revolução Industrial, a ordem capitalista foi dinamizada, aumentando seus domínios em todos os campos da atividade econômica, trazendo mudanças substanciais tais como as citadas por Deane (1975): a aplicação sistematizada e generalizada do conhecimento cientifico ao processo de produção nacional; a especialização da atividade econômica com vistas ao mercado internacional; o êxodo rural; a expansão e despersonalização da unidade de produção, antes realizada pela família e agora pela empresa; o uso de máquinas substituindo, em parte, o trabalho humano; e a emergência de novas classes sociais.

Dentre as idéias do capitalismo, destaca-se a divisão de trabalho, proposta por Smith (1952, citado por Rezende, 1986), que tinha como convicção a superioridade técnica através de três argumentos: (1) o ganho de tempo; (2) o crescimento da habilidade individual e, (3) agilização do trabalho pelo emprego de máquinas.

A fragmentação do trabalho revolucionou a indústria de 1800, evidenciando os resultados previstos por Smith. Entretanto, não trouxe a opulência universal que se estenderia a todas as camadas populacionais, ou seja, o trabalhador parcial não enriqueceu. $\mathrm{Na}$ verdade, o proletário perdeu o controle de sua própria produção, o que não traz a superioridade técnica, mas sim a garantia ao capitalista do poder de controle do processo de produção, aumentando a dependência do trabalhador ao controle hierárquico. Assim, o trabalho se torna duplamente alienado - à máquina e ao capitalista - a maquinaria reduziu o esforço físico do trabalhador, mas também a sua participação consciente e imaginosa, dispensou sua inteligência e anulou sua 
racionalidade.

A divisão de trabalho tornava mais nítido os contornos da separação social entre as classes: de um lado o trabalhador, o proletário; de outro o capitalista burguês. Esta divisão nasce, na verdade, em função da divisão social, condicionada pelas relações de poder: aquele que manda e aquele que obedece.

Numa sociedade dividida em classes pelas relações de produção, onde as massas proletárias apenas executam e a elite burguesa pensa, Rezende (1986) alerta para o fato de que a educação será, necessariamente, um instrumento de segregação social. Para o trabalhador, a educação deverá ter um enfoque utilitarista, a serviço do capital, de baixo custo, acrítica e prática - por exemplo, as escolas politécnicas. Fundamentalmente, deve impedir que ele se perceba como uma classe oprimida pelo capital, mas sim como trabalhadores com a possibilidade de ascensão social, desde que se submeta aos mandos do capitalismo. "Á escola capitalista compete moderar o potencial subversivo inerente à educação, escamotear a luta de classes e inculcar o fetichismo aos valores burgueses"(p.82).

Para os burgueses, a família, além da escola, são instituições que preservam os privilégios de classe. A família prepara os papeis econômicos e sociais que irão suceder. A escola vai reproduzir e desenvolver características pessoais coerentes com as posições hierárquicas ocupadas pela burguesia, tais como a liderança, autoridade e agressividade

A doença, no sistema capitalista, se apresenta como um sinal de conflito do homem integral com a sociedade que o fragmenta (Rezende, 1986). Desnutrição, tuberculose, trabalho do menor, mortalidade infantil e trabalho da mulher, são alguns 
exemplos lembrados por Berlinguer (1978). A desigualdade sócio-econômica e a situação de miséria associadas a exploração subumana da classe trabalhadora foram determinantes na proliferação de uma gama de patologias. Rezende (1986) cita a tuberculose como exemplo, que só explodiu como fenômeno de massa no fim do séc. XIX, com o confinamento da população camponês nas indústrias e em moradias insalubres. O infarto do miocárdio também pode ser citado, já anteriormente conhecido, é exacerbado atualmente pelas condições de vida nas sociedades competitivas, com seu cortejo de tensões, sedentariedade, frustrações e carências.

As práticas de saúde na sociedade capitalista pautam-se pelos valores de produtividade. A saúde passou a ser desejada como fator necessário para esta produtividade e a doença,um transtorno econômico.

\section{- Século XIX - grandes mudanças $\mathrm{x}$ velhos padrões}

O Século XIX trouxe mudanças de grande impacto sócio-econômico, como os efeitos do surgimento das ferrovias nos deslocamentos das indústrias, no desenvolvimento do transporte de mercadorias, nos estilos de férias e de lazer, na multiplicidade das fábricas, na administração dos trabalhadores, consolidando o capitalismo comercial e industrial (Gay apud Reis, 2002). Com isso, observou-se também, a emergência da burguesia como primeira classe dominante para a qual o trabalho está conjugado com o valor, visto ter sido este seu meio de valorização social.

No entanto, este mesmo século, segundo a visão de alguns historiadores, foi insistentemente tratado como sendo o "século de esposas sexualmente anestesiadas, 
obedientes, dedicadas à vida doméstica e à educação dos filhos; e de maridos de classe média promíscuos, na busca de prostíbulos ou da manutenção de amantes” (Reis, 2002, p.29).

A literatura médica sobre a erotização da mulher, nesta época, refletia a falta de compreensão do prazer feminino e os preceitos médicos acerca da sua sexualidade, podendo ser exemplificado com algumas postulações de Freud em sua tendência de identificar o masculino com a atividade e o feminino com a passividade. Apesar da coerência destas afirmações com o contexto cultural ao qual ele pertencia, indica a posição milenar destes modelos padronizados, cuja base, a da explicação do feminino, ficou durante muito tempo a cargo do homem.

Foi neste século, segundo Reis (2002), que em 1850, surgiu o preservativo efetivamente aperfeiçoado, um marco na história da sexualidade moderna, propiciando a política do planejamento familiar. Entretanto, mesmo com essa política, a mulher pouco proveito retirou, devido às poucas e errôneas informações que detinha sobre sua própria natureza, cuja sexualidade provocava profundas perturbações.

Além da anatomia e da fisiologia, havia na medicina um novo campo da prática que se voltava para a especificidade feminina, uma espécie de subespecialidade cirúrgica: a arte dos partos através da obstetrícia. Apesar das reações à presença do médico parteiro, vindas não só das mulheres, como também de outros médicos e de moralistas que consideravam a presença do médico no momento do parto uma indecência, no início do séc XIX, a obstetrícia já tinha o status de disciplina nas faculdades de medicina européias. Entretanto, como os cirurgiões eram chamados para atender os casos mais traumáticos, acabaram por desenvolver uma 
obstetrícia patológica, revelando muito pouco do parto normal, que continuava a ser atendido por parteiras.

Com a criação de maternidades e hospitais para mulheres, a obstetrícia ganhou um novo impulso transformando-se em especialidade reconhecida também pela clientela urbana que podia pagar os serviços do médico parteiro. Além disso, permitiu uma maior proximidade entre os médicos e as mulheres tornando possível que colocassem em prática o método clínico que se fundava na "soberania do olhar médico, estabelecendo a individualidade do corpo doente através da identificação dos sintomas, resultando não apenas a cura, mas a produção de um saber que nasce dessa experiência junto ao leito dos pacientes" (Martins, 2002, p.108). Desde então, o parto tornou-se cada vez mais um evento hospitalar, cercado de regras e protocolos.

Entretanto, a constituição da obstetrícia não é somente resultado do progresso da medicina. Conforme observa Martins (2002), este processo está relacionado a dois importantes acontecimentos: a transformação do médico numa figura respeitável e com autoridade para definir comportamentos e atitudes para a preservação da saúde e bem-estar das pessoas, sendo visto, inclusive como o protetor da mulher e da criança.. Assim, o reconhecimento e a confiança conquistados pelo médico devem ser entendidos como resultado deste novo papel político a ele atribuído e também da utilização dos conhecimentos científicos emergentes que possibilitava o controle de situações antes impossível, o que os dotava de um forte papel moral, bem de acordo com as transformações urbanas e familiares da época, ditando normas e organizando os espaços e a vida das pessoas.

Assim, a obstetrícia também surge para estabelecer a verdade sobre a mulher, fundada na observação dos fatos: o corpo feminino era talhado para a maternidade. 
Este era um princípio indiscutível e determinante a partir do qual a normalidade foi estabelecida e os papéis de gênero reforçados (Martins, 2002).

Na mesma época, constitui-se outra especialidade médica, a ginecologia, que se definiu como a ciência da mulher e que teve sua origem ligada à crescente intervenção cirúrgica no corpo humano e à teorização a respeito da sexualidade humana. A ginecologia não via a mulher somente pela capacidade reprodutiva e pela função materna, mas por sua diferença sexual.

Obstetrícia e Ginecologia, juntas, desempenharam importante papel na construção da categoria mulher, no século XIX. "Ambas procuraram revelar, à luz da ciência, os mistérios do corpo feminino e da sua sexualidade. Ambas utilizaram este saber como justificativa para a manutenção e refinamento da ideologia da domesticidade, onde cada sexo tem seu lugar e seu papel" (Martins, 2002, p.116).

A luta pelo direito do voto, o ingresso das mulheres na universidade considerada a chave da conquista feminina, mais do que o voto - através do movimento feminista iniciado na Europa e Estados Unidos, suscitaram sentimentos ambíguos, tanto em homens quanto numa parcela da população feminina. O nascente movimento feminista era visto como ameaça, enfrentando, além da oposição masculina, a resistência de grande parte de outras mulheres.

Se a resistência às mudanças era enorme em lugares como a Europa e Estados Unidos, no Brasil sequer havia preocupação com a possibilidade de alterações. O Brasil Colonial do início do século XIX ainda era um país essencialmente rural e escravista. O homem, dentro da família, era senhor absoluto de tudo e de todos. 


\section{- O amor romântico}

Foram também os burgueses do século XIX que sedimentaram a idéia do amor romântico nas relações homem-mulher, fortemente marcado por um registro poético, reformulando a maneira de ser e de nutrir seus sonhos mais íntimos.

Na Europa pré-moderna, de acordo com Giddens (1993), a maior parte dos casamentos não considerava a atração sexual mútua, eram contraídos sobre o alicerce da situação econômica. Para as famílias mais pobres, era um meio de organizar o trabalho agrário, ou como a única maneira de ascensão social para as mulheres. No entanto, as oportunidades para os homens de envolvimento em ligações extraconjugais eram freqüentes, gerando uma distinção entre a sexualidade casta do casamento e o caráter erótico-apaixonado dos casos extra-conjugais.

O amor-paixão, conforme analisado por Rougemont apud Costa (1988), teve como predecessor o amor cortês, cujo aspecto fundamental era a laicização do objeto ideal do amor, onde a imagem da mulher substituiu o lugar de Deus como objeto de adoração e desejo. Para Rougemont, no amor cortês, "o desejo nasce de sua impossibilidade; as provas.os obstáculos, as interdições, são as condições da paixão; a paixão é indissociável da transcendência da lei moral e social” (p.134). Sendo assim, o amor apaixonado é marcado por uma urgência que o coloca à parte das rotinas da vida cotidiana, com a qual, na verdade, ele tende a se conflitar.

O amor romântico, surgido no final do séc. XVIII, tornou-se distinto do amorpaixão, embora incorpore alguns resquícios dele. Diferente do amor-paixão, que extirpa de modo irregular, Giddens (1993) ressalta que o amor romântico desliga o individuo de situações sociais mais amplas, proporcionando uma trajetória de vida 
prolongada, orientada para um futuro previsto, mas maleável, e cria uma história compartilhada que ajuda a separar o relacionamento conjugal de outros aspectos da organização familiar, conferindo-lhe uma prioridade especial. O elemento do amor sublime tende a predominar sobre o ardor sexual, ou seja, "o amor rompe com a sexualidade, embora a abarque; a "virtude" começa a assumir um novo sentido para ambos, não mais significando apenas inocência, mas qualidade de caráter que distinguem a outra pessoa como especial”(pág.51). A absorção pelo outro, típica do amor-paixão, integra-se à orientação característica da busca.

Desde sua origem, segundo Giddens (1993), o amor romântico suscita a questão da intimidade, que se torna incompatível com a luxuria, não tanto pela idealização que se faz do outro, mas porque presume uma comunicação psíquica, um encontro de almas que tem um caráter reparador. Nas palavras de Giddens (1993) “o outro, seja quem for, preenche um vazio que o individuo nem sempre reconhece - até que a relação seja iniciada. E este vazio tem a ver com a auto-identidade: em certo sentido, o individuo fragmentado, torna-se inteiro" (p. 56). Desta forma, o amor se projeta em dois sentidos: apóia-se no outro e projeta um curso de desenvolvimento futuro.

A difusão das idéias do amor romântico estava profundamente envolvida com transições importantes que afetaram a vida social como um todo, reordenadas nas condições variáveis das atividades cotidianas. O surgimento da idéia do amor romântico deve, então, ser compreendida em relação a vários fatores que afetaram a vida das mulheres a partir do sec. XVIII, que propagaram os ideais do amor romântico. Giddens (1993) cita:

1 - A criação do lar, a partir da separação das esferas domésticas e publicas; 
2 - A modificação das relações entre pais e filhos, em conseqüência da separação acima citada, aliado à diminuição do tamanho das famílias, que permitiu o controle e cuidado das mães para com os filhos, fazendo com que as crianças passassem a ser vistas como vulneráveis e necessitadas de afeto;

3 - A invenção da maternidade, com a idealização do papel da mãe.

Com base nestes aspectos, observa-se que o amor romântico era essencialmente feminino. Com a divisão das esferas de ação, a promoção do amor tornou-se predominantemente função das mulheres, estando, de acordo com as teorias feministas (Lobato, 1997), claramente associadas à subordinação da mulher ao lar e ao isolamento do mundo externo.

De fato, como exposto por Giddens (1993), o caráter intrinsecamente subversivo do amor romântico foi, durante muito tempo, mantido sob controle pela associação do amor com o casamento e com a maternidade e pela idéia de que o amor verdadeiro, uma vez encontrado, seria para sempre. Nas palavras de Áriés (1987), a partir do séc. XVIII, constituiu-se "um ideal de casamento que impõe aos esposos que se amem, ou que façam de conta que se amam, como dois amantes..."(p. 100), o que pode ter causado como conseqüência, anos de infelicidade.

Em seus estudos sobre o amor romântico, Costa (1999), retira das analises de Sartre (1943), Perét (1956) e Simmel (1993), o que seriam as premissas do amor romântico:

1) A ideologia de um sentimento pessoal, apresentado como pleno, mágico, estático e superior em intensidade a qualquer outra experiência emocional do sujeito;

2) A desqualificação moral do exercício puramente físico da sexualidade; 
3) A exigência de uma sexualidade livre e, ao mesmo temo, submissa ao amor, o que a tornaria digna do amor sublime;

4) O estabelecimento de uma sexualidade como pré-requisito da realização do amor sublime e a conseqüente sexualização do universo;

5) A exigência de que o individuo entregue sua chance de felicidade ao acaso, já que a ele pertence o poder de revelar a pretensa imagem do amado, que ele possui sem saber, e que corre o risco de jamais encontrar.

Sendo assim, Costa (1999) analisa em seu estudo as três principais afirmações que sustentam o credo amoroso dominante.

a) $\mathrm{O}$ amor é um sentimento universal e natural, presente em todas as épocas e culturas: afirmar que o amor é universal e natural é apenas uma forma de maximizar seu teor de idealização, o que não significa que amamos porque a natureza assim o exige. Para Costa (1999) o amor foi inventado, assim como o casamento. Nenhum dos seus constituintes afetivos, cognitivos ou conativos é fixo por natureza (p.12).

Segundo Paz (apud Costa, 1999), o sentimento amoroso é universal, o que não é universal é a idéia do amor.

b) O amor é um sentimento surdo à voz da razão e incontrolável pela força de vontade: ao acentuar o aspecto involuntário ou incontrolável do amor, são sublinhados as sensações e sentimentos em detrimento das crenças e julgamentos que lhes são, da mesma forma congêneres, o que significaria caucionar a idéia romântica de que ao amar, o sujeito estaria entregue ao destino, sem chance de reação.

Segundo o autor, na prática amorosa, a racionalidade está tão presente no ato de amar quanto as mais impetuosas paixões. "Amar é deixar-se levar pelo impulso 
passional incoercível, mas sabendo quem ou o que pode e deve ser eleito como objeto de amor" (p. 17).

O amor, como mostram Hunt (apud Costa, 1999) e Giddens (1993), não é uma emoção capaz de vencer qualquer barreira sócio-cultural para atingir suas finalidades. Em geral, amam-se pessoas cujo padrão estético, situação de classe, pertencimento étnico e racial, etc., preencham as expectativas culturais do candidato ao amor. A realidade social e psicológica dos sujeitos, complementa Costa (1999), demonstra que o amor é seletivo como qualquer outra emoção presente em códigos de interação e vinculação interpessoais. Sendo assim, pode-se afirmar que o amor é constituído por sentimentos e sensações, mas também por crenças e julgamentos.

Costa (1999) procura diferenciar sentimentos e sensações de crenças e julgamentos. Sentimentos e sensações se caracterizam pela imediatez, não reflexividade e indubitalidade com que se apresentam à consciência. Crenças e julgamentos, ao contrário, são sempre apoiados em relatos inferenciais feitos a partir de outras crenças e julgamentos possíveis de revisão ou contestação pelo outro. Fundam-se portanto, em proposições racionais sobre a existência de estados de coisas para a ação humana ou para a modificação de eventos mentais. Por exemplo, sentimentos e sensações podem ser causas de alterações de estados mentais, mas não são os motivos dessas alterações. Ao fornecer razões, estou me referindo às crenças e julgamentos.

c) O amor é condição sine qua non da máxima felicidade a que podemos aspirar: o amor romântico, quando se estabilizou como norma de conduta emocional na Europa, respondeu aos anseios de autonomia e felicidade pessoais, transformando-se em um elemento de equilíbrio indispensável. Ainda hoje, o amor é 
mantido como ideal de felicidade.

Discutindo tais questões, Costa (1999), assume que "discutir sobre o amor é se situar na posição de quem pensa de modo axiológico"(p. 162), e isso se alia à visão de que as opiniões sobre o amor, em nosso atual modo de vida, são orientadoras de conduta e, portanto, repercutem no agir moral.

Neste sentido, Solomon (1993), citado por Costa (1999), insiste em que muitas das razões do coração devem mudar, mas não seu cerne moral e sua intensidade passional. $\mathrm{O}$ amor pode ser uma afeição muito mais geral de estar com, de ser apreciado, de ser feliz junto, de querer o melhor para o outro, de fazer tudo pelo outro. Em função das inseguranças constitutivas da subjetividade moderna, é o amor que provê o sentido que mais se necessita, o sentimento de pertencimento, pelo processo de formação de identidade. Ou seja, o amor atua como o lugar de reasseguramento da identidade: a virtude do amor está no fato de o desejo amoroso ser o desejo de partilhar uma só identidade.

O sujeito do amor romântico, como observado pelos vários teóricos analisados por Costa (1999) - Bloom. Badinter, Nussbaum e o próprio Solomon era o que sabia distinguir seu verdadeiro mundo interior, da sedução das sensações e costumes da moda. Esse mundo interior era feito de aspectos estáveis, construídos por práticas de auto-controle, disciplina, sacrifício, tenacidade, força de vontade, etc. Decepções, frustrações e sofrimentos eram suportáveis, porquanto vividos como teste de continência sentimental. Experimentar a realização sentimental, sob o modo do amor romântico era, de fato, uma obrigação cultural que se sustentava na repressão da sexualidade feminina, na crença da verdade sentimental da natureza do homem, na desigualdade social entre homens e mulheres, na firmeza dos afetos familiares, na 
importância do convívio doméstico, nos preconceitos da moralidade burguesa, no agudo sentimento de responsabilidade para com o futuro dos filhos e dos ascendentes, etc. "O amor, na ideologia romântica, era a sentinela moral que protegia o sujeito dos instintos vis e a família da depravação do mundo (p. 214).

Durante muito tempo, os ideais do amor romântico afetaram mais as aspirações das mulheres do que dos homens, embora, é claro, os homens também tenham sido influenciado por ele. Pode-se observar neste aspecto, como o confinamento da sexualidade feminina ao casamento era importante como símbolo da mulher respeitável. Isso, permitia aos homens conservar distancia da intimidade, ao mesmo tempo em que lhe permitia a busca do prazer sexual, enquanto mantinha a situação do casamento como um objetivo primário das mulheres.

\section{- Século XX: Revolução Sexual e de Costumes}

Os complexos processos de transformações que tornaram possível a mudança da sociedade feudal à sociedade capitalista abarcam questões muito além da transformação do modo de produção econômica e governabilidade. Foi um descontínuo, porém incessante, movimento de transformação que abarcou o conjunto das instituições da sociedade; não apenas surgem o Estado e as nações modernas e suas formas democráticas, mas também operam redefinições em toda a extensão e profundidade do tecido social, reorganizando-se a partir da família e da escola.

Neste sentido, Fernández (1994) ressalta duas conseqüências: a redefinição do espaço público e privado proporcionados por este conjunto de mudanças e o começo de um processo de produção de novas formas de subjetividade. 
No que diz respeito às mulheres, pode-se diferenciar duas etapas na sociedade industrial: a primeira, onde a imagem da mulher se identifica com o encerramento doméstico e a segunda, a partir da segunda metade do século XX, onde as mulheres alternam suas responsabilidades entre o mundo público e o mundo privado.

De acordo com esta autora, a forma jurídico-administrativa da modernidade é o contrato. Assim, um dos objetivos principais da nova sociedade será delimitar uma perfeita territorialização dos cidadãos para garantir uma perfeita circulação dos bens. Ao Estado fica o encargo de garantir os intercâmbios vinculados aos contratos. A governabilidade dos Estados modernos terá como um dos seus focos centrais o controle das populações e, seu verdadeiro poder radicará na produção de consensos que garantam sua legitimidade.

Estabelece-se assim, diferentes formas institucionais para aqueles que ficam fora do contrato e diferentes formas de assistência e tutela, controle e disciplina. As mulheres e crianças se incluem naquelas formas de sociabilidade correspondentes a sua classe social, porém não são sujeitos de contrato, sua possibilidade de circulação é restrita ao mundo privado, e não são cidadãs no pleno sentido, mas inscritas na figura jurídica da tutela.

O mundo privado é o mundo da interiorização, em oposição à exterioridade da vida publica. Sua base é o núcleo familiar, organizado em torno da comunidade de afetos, a educação dos filhos e a gestão doméstica dos sentimentos. Ou seja, uma inversão de sentimentos em tarefas e valores pessoais, assumidos como o produto de uma eleição individual.

Assim, linguagem, poder e dinheiro são definidos como atributos masculinos, 
enquanto o feminino se desenvolve em um mundo privado, sentimentalizado, definido como um mundo de retaguarda, marginal e subalterno, privado das características de produtividade, poder organizacional e potencialidade cognitiva.

Isto não significa, conforme ressalta Fernández (1994), que o mundo privado não seja um espaço onde se manifestam suas próprias formas de produção, organização e conhecimentos, ou onde não está em jogo o poder. Porém, estas dimensões ficam invisibilizadas porque suas características não respondem aos parâmetros de produção, organização e poder que tem no mundo público. Além disso, a narrativa do privado sentimentalizado impede que seja vista outra coisa no mundo doméstico, que não afetos.

Sendo assim, as mulheres burguesas tuteladas - pelo pai e a seguir pelo marido - desenvolvem sua vida no meio privado e doméstico. Os organizadores de sentido que guiam suas práticas, seus sistemas de prioridades, seus sentimentos se expressam nas figuras de mãe e esposa. Com relação às mulheres operárias, desde o princípio do capitalismo até a atualidade, pode-se observar um significativo atravessamento de classe e gênero. As mulheres operárias, enquanto operárias, foram sujeitos de contrato, porém, por serem mulheres, seus salários foram sempre mais baixos e suas tarefas desenvolvidas em piores condições, além do particular agravo de abuso sexual.

Conforme salienta Bruschini (2002), a atuação da mulher no mercado de trabalho se dá, até os dias atuais, em condições visivelmente desiguais e excludentes. O preconceito de inferioridade designado ao sexo feminino ao longo dos séculos através da religião, das leis, da escola e da família, onde, cotidianamente, a própria mulher reproduz a superioridade masculina através da educação formal ou informal - 
é apropriado e reproduzido nas relações de trabalho, onde vende sua força de trabalho a preço mais baixo, concentra suas atividades em setores extensivos do doméstico e permanece, via de regra, distante das esferas de comando e decisão entre os próprios trabalhadores.

Com o capitalismo moderno se assiste ao que $\mathrm{M}$. Weber, citado por Fernández (1994), definiu como a "racionalização das práticas". Este processo permanente de racionalização de todas as práticas sociais implicou a expansão paralela do "saber racional", saber técnico em forma de princípios e leis, que tem como conseqüência a aparição do especialista. Assim, as ciências e os especialistas estabelecem o normal e o patológico, o feminino e o masculino. Instituem regimes de verdade que legitima uma nova ordem social e se converte em um dos seus produtores de significado mais importante.

Esta redefinição será regida por códigos próprios e serão diferentes as formas de circulação dos saberes: um âmbito público, racional, exercido por especialistas, e um âmbito privado, sentimental, de saberes empíricos, exercidos por mulheres.

No Brasil, na década de 1930, foi formulada uma legislação específica para regularizar o trabalho feminino que procurava proteger a maternidade das trabalhadoras e que revelava o trabalho feminino como uma extensão natural de seu trabalho doméstico. Embora no plano jurídico formal, todas as brasileiras tenham conquistado os direitos de cidadania plena, a maioria não conseguiu exercer quaisquer direitos. Com ocupações mal remuneradas e não-prestigiadas, conforme Besser (1999), a meta real de independência tornou-se uma ilusão.

Esta situação evidencia, como afirma Barbosa (2001), a distância de um 
discurso que idealiza a conquista da independência feminina e a realidade concreta da vida da maioria da população.

A partir da década de 1930, a expansão dos serviços públicos de saúde no Brasil, ampliou também a assistência à saúde das mulheres. Isto se deu, entretanto, privilegiando-se o ciclo gravídico-puerperal, justificado pela alta taxa de mortalidade infantil. Neste contexto, Barbosa (2001) ressalta que o definido como saúde da mulher, era a "mulher de boa saúde para gerar filhos sadios". Os parâmetros significativos na estruturação do discurso sobre a maternidade eram reassegurados, sendo: (1) atribuído valor social inferior ao corpo da mulher em relação ao do filho, evocando o "natural" altruísmo da mãe; (2) a naturalização do confinamento doméstico, ou seja, a organização da vida em função do cuidado com os filhos, a despeito das precárias condições de sobrevivência e/ou do trabalho remunerado; (3) as obrigações maternas vistas como "naturais", enquanto as paternas são eletivas.

A partir da segunda metade do século XX ocorreram grandes mudanças nos papéis, funções e relações familiares. Com o advento da Revolução Sexual, o movimento hippie e o discurso científico sobre o perigo da explosão demográfica, à partir da década de 60, surgiram significativas mudanças sociais e quebras de paradigmas, abalando os valores e instituições. Esta situação trouxe modificações nos padrões morais e, em especial, nos sexuais, com a desvinculação da sexualidade dos objetivos de reprodução.

O Brasil dispõe, desde 1983, do PAISM - Programa de Atenção Integral à Saúde da Mulher, desenvolvido pelo Governo e considerado um dos mais abrangentes e conceitualmente avançado do mundo. Além disso, o Brasil é signatário de inúmeros documentos e declarações internacionais que estabelecem agendas de 
compromisso na promoção da saúde e dos Direitos Reprodutivos das brasileiras (Barbosa, 2001).

Entretanto, um imenso contingente de mulheres, condicionadas pela situação de pobreza, pela falta de opções e acesso a direitos sociais, não são beneficiadas. Conforme pontua Barbosa (2001) citando Denenberg (1997),

“... este desequilíbrio se deve, provavelmente, a complexos determinantes psicossociais relacionados ao papel das mulheres como cuidadoras da família, por sua relativa pobreza e pelo paternalismo e mesmo hostilidade com que o sistema médico aborda seus problemas".

Entre as décadas de 70 e 90, conforme Portella, os direitos reprodutivos e sexuais passam a ser compreendidos como uma quarta geração de direitos que se sucedem aos civis, políticos e sociais, tendo sua formulação a partir das ações e articulações internacionais dos movimentos feministas que resultaram nas definições, não sem conflito, na Conferencia das Nações Unidas de População e Desenvolvimento, realizada no Cairo, em 1994, e na Conferencia de Beijing, em 1995.

De modo geral, os direitos reprodutivos, se baseiam no reconhecimento do direito básico, de todos os casais e indivíduos, de decidir livre e responsavelmente sobre se desejam ou não ter filhos. Envolve ainda o direito de receber informações e meios para tomar estas decisões, sem sofrer discriminações, coações ou violência, tal como se estabelece em documentos de direitos humanos.

Portella (2002) ressalta para o fato de que os direitos reprodutivos se reportam a aspectos da vida privada e à intimidade, objetivando criar condições para que a igualdade e a justiça se façam presentes também nestas relações. Ainda que o 
espaço doméstico sempre tenha sido tratado na esfera pública e regulado no campo do direito e da política, a diferença está na participação das mulheres no debate atual. Sendo assim, a luta pelos direitos reprodutivos e sexuais tornou visível uma série de situações injustas vividas na intimidade, cujas consequiências negativas atingem a saúde e o bem estar sobretudo das mulheres, mas também dos homens.

A escola foi um importante espaço para as transformações sociais, pois, ao mesmo tempo em que reforça os papéis tradicionais de gênero, oferecia instrumentos que possibilitavam às alunas assumirem novas funções, além daquelas aceitas como tradicionalmente femininas (Archanjo, 2002).

Assim, enquanto era esperado dos homens o investimento nos estudos e numa carreira que os possibilitassem, no futuro, exercer o papel de provedor da família, das mulheres era esperado que, ao lado ou acima da formação intelectual, estivesse o ideal de casamento e da maternidade. No entanto, ela também oferecia oportunidades de experiências sociais diversificadas para as alunas, possibilitando a participação em atividades culturais, sociais e esportivas, o acesso a novos universos de pensamento, assim como a preparação para uma futura profissionalização..

As mulheres passaram, durante muito tempo, da condição de filhas para a de esposas, depois para a de mães, num espaço definido pelo homem na relação a dois e pelo papel que era esperado que ela desempenhasse no ciclo de sua vida familiar. Com as transformações ocorridas nos últimos anos, este modelo tradicional tornou-se desatualizado, com a priorização, pela mulher, de objetivos pessoais, a carreira, a independência financeira, antes do casamento. $\mathrm{Na}$ verdade, elas devem fazer coexistir em sua vida cotidiana as funções de seu trabalho remunerado, do mundo público e seu trabalho invisível, doméstico. Assim, tanto nas classes mais ou menos 
favorecidas, cada qual com estratégias próprias, se desenvolveu um complexo processo de incorporação deste novo modelo de vida privada e, ao mesmo tempo, de conservação das formas próprias de sociabilidade que as caracterizavam socialmente.

A modernidade também produziu uma nova dimensão para a conjugalidade: $\mathrm{o}$ discurso do amor romântico ressaltou a união indissolúvel, "até que a morte nos separe", da fidelidade recíproca, um ideal de harmonia, etc. Portanto, o matrimonio moderno acentua seu sentido no vínculo amoroso indissolúvel e na consensualidade do contrato entre as partes. Entretanto, o discurso da natureza feminina, os mitos da maternidade e da passividade sexual, além do discurso do amor moderno, trabalharam eficaz e produtivamente, gerando argumentos e estratégias institucionais específicos com que contará a modernidade para a produção e reprodução de um dos pilares da subjetividade feminina: ser do outro.

Esta subjetividade, a partir de onde as mulheres se posicionam, presente inclusive em muitas mulheres com independência financeira ou protagonismo público, cria condições para um particular tipo de dependência pelo qual o homem não é somente seu objeto amoroso, mas também quem ministra seu reconhecimento.

Além destes sentimentos conflituosos, é relevante analisar a visão diferente que têm o homem e a mulher em relação ao casamento. Segundo Reis (2002), os homens vivenciam uma situação ambivalente entre o sentimento de querer e sentir-se numa "armadilha". Entretanto, no decorrer da relação conjugal, as mulheres tornamse mais sintomáticas e predispostas ao estresse.

De acordo com diversos estudos, analisados pela autora, este processo que fragiliza mais as mulheres casadas do que os homens e as mulheres solteiras, é o 
envolvimento emocional mais elevado com a vida de todos que a cercam, ocasionando uma sobrecarga de papéis. É esperado da mulher casada poupar o marido da árdua tarefa da criação dos filhos, mostrar-se suficientemente capaz de cumprir suas obrigações sem depender do apoio dos outros, adaptar-se a toda e qualquer mudança que porventura for proposta pelo marido, e ainda, compreender a indisponibilidade e a falta de diálogo na vida conjugal. Estas dificuldades tornam-se ainda maiores quando se trata de conciliar o trabalho fora de casa com as tarefas domésticas, aliado ao sentimento de estar falhando como mãe ou como profissional, elevando a tensão feminina.

De acordo com Fernández (1994), um dos suportes básicos desta tensão é a produção dos dispositivos de domesticação feminina e de dupla moral masculina. Assim, o cenário matrimonial se torna, ainda hoje, o lugar de apropriação e controle da sexualidade feminina. Se bem que cada vez mais, as tecnologias contraceptivas tem revertido substancialmente a alienação de seu próprio corpo como corpo reprodutor, não se poderia afirmar o mesmo com relação a heteronomia do corpo erótico feminino, onde sua passividade sustenta, ainda hoje, tanto a atividade do erotismo masculino, como a conjugalidade monogâmica unilateral.

Com o esgotamento dos recursos psíquicos que vão sendo subtraídos nos freqüentes enfrentamentos na sua vida, a alternativa escolhida para sua sobrevivência é, muitas vezes, por uma zona de conforto. Paradoxalmente, esta zona de conforto não representa necessariamente uma alternativa confortável. Esta zona representa um conforto somente por ser conhecida por ela, e, na sua percepção de mundo, por oferecer menos riscos que alternativas que a colocariam diante de algo desconhecido. Para realizar esta transgressão é necessário romper com todos os padrões 
internalizados ao longo da vida (Reis, 2002).

A história do feminino é marcada por mudanças que, ao mesmo tempo em que abre perspectivas para a mulher, também impõem sérias restrições abrindo um abismo emocional entre os sexos. A masculinidade passa a se manifestar também na crescente violência exercida contra as mulheres, conforme demonstra um estudo realizado por pesquisadores da Universidade de Brasília, citado por Campos (2000), sobre violência conjugal. Neste estudo foi observado que $80 \%$ dos homens agressores têm dificuldade em aceitar os novos padrões de comportamento feminino. Entre as mulheres, ainda que $10 \%$ também resistam a estas mudanças, as outras $90 \%$, ou seja, a maioria, não hesitam em buscar novas formas de relacionamentos.

Concluindo, observa-se que existe uma trajetória histórica justificando a sedimentação de uma interação polarizada entre homens e mulheres, na qual a mulher vem ocupando, por diversos motivos, o papel inferior. No centro destas motivações está o aspecto econômico. Nota-se que foi a partir da mudança no modo de produção, que tomou impulso o sistema de organização androcêntrica que resiste até hoje. Outro dado relevante a ser considerado, é a assimetria sexual das expectativas afetivas, que contribuem impondo barreiras entre os sexos: enquanto as conquistas masculinas são valorizadas pela quantidade, as mulheres continuam fixadas no aspecto romântico e exclusivista de cada envolvimento amoroso.

No entanto, constata-se também que, neste processo de construção de gênero, homens e mulheres não se comportam como sujeitos passivos. Eles participam desse processo contestando, aceitando, rejeitando ou adaptando as atribuições sociais de gênero de sua época. 
É importante ressaltar ainda que não se pretende indicar à mulher a condição de vítima, mas considerar que esse modelo pressupõe diferenças que colocam como vítimas desse processo patriarcal tanto homens, como mulheres, embora se credite um valor de vantagem ao exercício do masculino. No século $\mathrm{XX}$, a figura masculina também aparece neste cenário de transformações de valores procurando um novo lugar. O homem procura algo que o legitime no exercício de um papel sobre o qual ele não detém mais exclusividade. Por isso, esta conquista em curso, só se fará completa com a participação dos homens, ou seja, depende também da libertação do homem de tudo o que contribui para a perpetuação do seu status quo.

\section{3 - AIDS: desafios de um novo tempo}

Atualmente, ainda vivendo a acomodação das enormes transformações sociais, econômicas e culturais, que tem colocado homens e mulheres diante da incômoda situação de perda e reestruturação de valores ainda não completamente estabelecidos, nos deparamos com fenômenos sociais perturbadores, causados por uma doença, a AIDS, que além de atingir o estado biológico, faz ressurgir aspectos conflituosos das relações humanas, tal como a relação de poder entre gêneros.

O fato da epidemia de HIV/AIDS atingir preferencialmente mulheres jovens, aliado à importância que a transmissão vertical do vírus tem na dinâmica de sua disseminação entre a população feminina, vem produzindo uma série de desafios e desdobramentos para a saúde reprodutiva e sexual que nem sempre são tratados em sua complexidade e abrangência. Esta situação vem agravar um quadro de saúde reprodutiva já bastante precário, caracterizado, em linhas gerais, pelo agravamento de outras DSTs, por um perfil distorcido de uso de métodos contraceptivos, pelo 
recurso indiscriminado à esterilização cirúrgica e ao parto cirúrgico, pela prática clandestina do aborto e pela manutenção de elevados índices de mortalidade materna e por câncer de colo de útero e de mama.

Além disso, as novas demandas geradas pela epidemia de HIV/AIDS se apresentam a serviços cronicamente deficitários e meio a uma enorme crise de financiamento do setor saúde que, salvo raras exceções, tem respondido a esses impasses de maneira setorizada e verticalizada, com uma forte ênfase na prevenção da transmissão vertical do vírus que, entre outras coisas, reedita a histórica priorização da assistência pré-natal com a finalidade primeira de beneficiar o recémnascido.

A possibilidade de transmissão vertical, aliada à disponibilidade de intervenções terapêuticas que reduzem esse risco, têm contribuído para a eleição do pré-natal como o momento de detecção da infecção pelo HIV em mulheres. Isso, além de suscitar discussões e confrontos de natureza política e ética, como o direito à maternidade da mãe soropositiva, pressupõe reconhecer seu direito de decisão sobre a reprodução e propiciar o suporte e os serviços necessários para sua realização. Saber-se portadora do HIV é, sem duvida, um dos fatores a serem considerados no processo de decisão reprodutiva, não só pelos risco de infecção do bebê, como pela saúde da própria mulher (Lago, 1999).

O fato é, segundo Barbosa (2001), que a infecção pelo HIV incide no cerne da identidade socialmente definida para as mulheres - a maternidade - o que as coloca diante de uma contradição: a mesma sociedade que as definiu como procriadoras, rejeita-as e recrimina-as, caso desejem ter um filho sendo soropositivas. 
Sem deixar de levar em conta as considerações médicas em torno do risco de transmissão do vírus e da possibilidade de prevenção, Rohden (2002) ressalta complexidade em torno do desejo de uma mulher soropositiva em ter filhos, envolvendo, por um lado, o respeito aos direitos do individuo em realizar plenamente seus projetos de vida e, por outro, os direitos da criança que vai nascer e as condições de vida que vai ter, considerando tanto a sua própria saúde quanto a dos pais.

Isso remete a questão do sujeito. Não basta que existam direitos formulados, leis aprovadas e condições materiais que permitam sua realização. É preciso ainda que exista um sujeito que conheça os direitos, deseje-os, reivindique-os e seja capaz de exerce-lo. Assim, além de colocar questões referentes ao conteúdo dos direitos, o que a Aids nos coloca é o problema do sujeito de direitos (Portella, 2002).

Em qualquer dos casos, no entanto, é necessário compreender que as mulheres são sujeitos de direitos, capazes de decidir a respeito de sua própria vida. Cabe aos serviços de saúde fornecer-lhes informações, acolhimento, assistência e condições para que estas decisões sejam tomadas da melhor maneira.

Tratar a epidemia de AIDS dentro de um contexto dos direitos reprodutivos significa ainda possibilitar formas que permitam a concepção nos tempos atuais, tornando mais segura a relação sexual entre casais discordantes que desejam ter filhos. Isso é cada vez mais importante, se considerarmos que os recentes avanços ocorridos com relação ao uso das terapias combinadas vêm possibilitando um convívio com a AIDS similar às das doenças crônicas.

Atualmente há possibilidades técnicas, disponíveis nos serviços de saúde, 
para as mulheres soropositivas que desejam engravidar. Nos serviços públicos é disponível o tratamento com medicação específica (AZT). Para além dos serviços públicos, pode-se falar em termos de prevenção através de reprodução assistida desenvolvida na Itália e mais recentemente no Brasil, Espanha e México (Faúndes, 2002).

Porém, a gestação da mulher soropositiva para o HIV vai além do sucesso técnico que possa ter a sua gravidez. A questão envolve o posicionamento dos profissionais de saúde a favor ou contra a reprodução baseados, muitas vezes, mais na questão de valores do que na competência técnica que lhes é conferida pela sua inserção profissional (Maksud, 2002).

A epidemia de Aids não atinge apenas indivíduos, mas a família como um todo. Quando a doença é identificada a partir do marido/pai, atinge todos os aspectos da vida familiar e introduz sérios complicadores na relação do casal e, deste com os filhos, no sustento da família, nas redes familiar e social de apoio. Oliveira (2000), procurou identificar as dificuldades no enfrentamento das perdas trazidas pela doença no contexto familiar, sob o prisma da esposa. Para tanto investigou a experiência da esposa/parceira que enfrenta o adoecimento e morte do marido por Aids, sendo obrigada a lidar com sérios agravantes psicossociais decorrentes da doença e também com o subseqüente luto pessoal e familiar.

Um fator ressaltado pela autora, se refere a freqüente existência de filhos soronegativos convivendo proximamente com pais e outros irmãos soropositivos. Pouca atenção se tem dado ao atendimento dessas crianças e o ônus do cuidado é, prioritariamente, da mãe. Esta situação acarreta uma dificuldade a mais para a mulher, principalmente por estar sobrecarregada ou extremamente desgastada com 
seu próprio stress, com as demandas práticas do cotidiano ou com sentimento de luto devido a perdas recentes e outras tantas dificuldades.

A ampliação da discussão e o reconhecimento das interfaces da epidemia de Aids são urgentes, principalmente quando se considera que, no Estado de São Paulo, a AIDS, desde 1997, é a principal causa de morte entre as mulheres de 15 a 49 anos (Barbosa \& Lago, 1997). Existe indicações de que o diagnóstico de AIDS entre as mulheres ocorreria em fase mais avançada, resultando em intervenção tardia e, conseqüentemente, em uma diminuição do tempo de sobrevida. Isso aconteceria porque as mulheres tendem a procurar os serviços de saúde em fase mais avançada, mas também porque são diagnosticadas erroneamente ou não são diagnosticadas. Apesar das mulheres freqüentarem mais os serviços de saúde, sintomas que são comuns à AIDS e a outras doenças, tais como a fadiga, perda de peso, apetite, insônia e falta de ar, teriam entre as mulheres maior probabilidade de serem entendidos como fatores psicológicos e, portanto, não são investigados.

Além disso, quando o atendimento ocorre, estará freqüentemente restrito à prescrição de medicamento. Raramente, este momento será aproveitado para esclarecer as mulheres sobre as formas de transmissão dessa infecção e da importância da adoção de práticas mais seguras, que impeçam a reinfecção ou aquisição de outras DSTs. Nesse sentido, é fundamental a criação de oportunidades de aconselhamento individual e em grupo, que facilitem a construção de novos modelos de relacionamento e interações sexuais.

Caso similar se constata com relação às estratégias de programas voltados para a prevenção da gravidez, onde o planejamento ainda é pensado como um programa verticalizado, que tradicionalmente privilegia a eficácia dos métodos de 
contracepção, em detrimento da saúde da usuária. Esta forma de conceber o planejamento familiar contribuiu para uma cultura conceptiva que se mostra hoje extremamente perversa, já que acabaram por desestimular o uso de contraceptivos capazes de promover a negociação sexual e a divisão da responsabilidade por evitar filhos (Saldanha \& Dias, 1997).

A prevenção se introduz no casamento como uma proposta de mudança no vinculo do casal. Ao falarmos de casamento é preciso considerar não apenas a sexualidade, mas de relações afetivas que incluem o sexo e a sexualidade, mas envolvem também muitos outros aspectos. Segundo o conceito de Dicks (1993), o campo total da vida conjugal abrange distintas áreas de cooperação: sexual, afeição, respeito pessoal, criação dos filhos, tarefas domésticas, política financeira e familiar, rede social, cultura e lazer, valores políticos e religiosos.

Sendo assim, as propostas de prevenção entre casais entram em choque com as expectativas implícitas na constituição da família, tendo como conseqüência, de acordo com Oliveira (2000), a colocação de cada um dos pólos de conflito em uma área mental diferente: o medo da doença fica com o aspecto cognitivo, dissociado da vivência afetivo-sexual diária, onde fica localizado o caráter inquestionável do vínculo afetivo da relação.

Em suma, ao colocar em discussão aspectos dos comportamentos da esfera pública e privada, a Aids questiona as estruturas de poder, as culturas e suas morais. Em um contexto sócio-histórico em que prevalece uma moral cristã apoiada pelo Estado, a mulher encontra dificuldades em adotar práticas preventivas e de criar alternativas de auto-cuidado que sejam viáveis dentro de sua realidade. Nesse sentido, nas palavras de Roso (2002, p. 392), "seu corpo submisso, pouco cuidado, 
revela a cultura na qual ela vive. Esse corpo não é um fato isolado, ele é o corpo social, modelado pelas instituições sociais (Estado, Igreja, etc.). O corpo físico e social se fundem, e o primeiro se modifica em função do segundo. Ao que completa citando Gonçalves (1990), “... cada corpo expressa a história acumulada de uma sociedade, que nele marca seus valores, suas leis, suas crenças e seus sentimentos, que estão na base da vida social”.

\section{4 - Justificativa e Objetivos}

A discriminação de gênero, como qualquer outra discriminação, se fundamenta em todas as suas dimensões pelo problema do poder. O poder, enquanto tal, sustenta sua eficácia nos discursos que instituem. Assim, os discursos e mitos sociais ordenam, legitimam, disciplinam e definem os sujeitos de desigualdades e sua subordinação nos espaços sociais e subjetivos. De tal forma, seus posicionamentos são o resultado histórico, cultural, porém também singular das forças em jogo, das quais a subordinação é seu efeito completo, difuso e recorrente (Fernández, 1994).

A desigualdade faz parte de um dos problemas centrais de toda formação social: produzir e reproduzir incessantemente as condições que a tornam possível. Para que isso aconteça, um dos pontos estratégicos é garantir que pareça natural. Esta naturalização não é um processo espontâneo, ao contrário, precisa ser produzido.

Enquanto organizadores de sentido, os mitos sociais se inscrevem em uma dimensão sócio-histórica de grande relevância, a produção de sistemas de significações que tornam possível o consenso em uma sociedade. Desta forma, geram os suportes econômicos, sociais, políticos, simbólicos, eróticos e subjetivos dos 
sujeitos sociais nas instituições, tornando possível a disciplina e o policiamento da sociedade. O que Gramsci, apud Minayo (2001), denomina "astúcia da hegemonia", ou seja, a capacidade dos grupos de poder para apresentar ao conjunto da sociedade seus interesses corporativos como de interesse geral.

As três ordens imaginárias da família burguesa - mito da maternidade, passividade feminina e mito do amor romântico - instituem a legitimação de práticas denominadas poder masculino, através da figura social do marido, que posiciona a esposa em dependência econômica, erótica e subjetiva.

Com a criação do mito da maternidade, a família torna-se o lugar dos afetos, mas também o espaço onde, através de suas dimensões fundamentais em relação ao poder - marido-mulher, pais-filhos - se desenvolverão os elementos principais do dispositivo da sexualidade. Assim, ativo e passivo, desde suas origens, não está referido aos gêneros, mas sim, demarca relações de poder.

A prioridade dos afetos nas relações familiares implicou, no que diz respeito à conjugalidade, no processo de construção social de um novo conceito de amor: o amor romântico. Sua mistificação, junto com o amor maternal, outorga uma nova posição às mulheres nos contratos e legitimações entre os gêneros sexuais.

O matrimônio moderno acentua seu sentido no vinculo amoroso indissolúvel e na consensualidade do contrato entre as partes. O discurso do amor conjugal também implica, para o homem, no papel de protetor e, para a mulher, uma delimitada práxis social, com a postergação de suas metas individuais, por amor ao marido e aos filhos. Tais significados geraram os argumentos e estratégias institucionais específicas para a produção-reprodução de um dos pilares da 
subjetividade: ser do outro.

Este "ser do outro", a partir de onde as mulheres se posicionam, constitui em um dos principais pontos de vulnerabilidade e fragilização, determinando diversas formas de tutelas objetivas e subjetivas. Esta subjetividade com base sentimental, faz com que, junto aos sentimentos amorosos que unem um homem a uma mulher, se instituam posições de poder que geralmente desfavorecem as mulheres, ou seja, faz com que permaneçam presas em relacionamentos de forte dependência, onde, o parceiro, além de objeto amoroso, é também aquele que ministra seu reconhecimento, colocando em jogo a sua valorização.

$\mathrm{Na}$ atualidade, esta fragilidade da mulher se encontra menos visível, mas nem por isso tornou-se menos efetiva. Embora cada vez mais denunciada e combatida na esfera pública, é nas instituições do mundo privado, na intimidade dos enlaces e desenlaces com o outro sexo que se localizam as estratégias centrais desta questão.

A partir destes pressupostos, surge a necessidade de questionar, problematizar o campo de estudo onde são pensadas as relações e diferenças de gênero. Para tanto, é necessário indagar os priores lógicos que constituem as condições de possibilidade de um saber, seus princípios de ordenamento, suas formas de enunciação e seus regimes de verdade.

Nenhum campo de conhecimento se constitui fora de uma demanda histórica. É ela quem pontua as "urgências" com que se responderá com os dispositivos de ação específicos. Assim, se poderá evidenciar, de acordo com Fernández (1994), como as áreas de problematização que delimitam os discursos que 
a constituem, e os "impensáveis" que as sustentam, estão entrelaçados com o movimento social que originou a demanda, a urgência histórica que a tornou possível, as necessidades do social que a manifestam, os agentes que a instituem, o lugar nas questões sociais que ocupam e os dispositivos que instrumentam.

A premissa que guia esta indagação é a de que as significações imaginárias sociais instituídas perduram mais que as transformações que operam dentro do período histórico que a legitima. Assim, muitas novas práticas de mulheres são ressignificadas socialmente ou por elas próprias, a partir de organizadores de sentido que estabelecem os mitos tradicionais da feminilidade.

Partindo desta premissa, ao se tratar a soropositividade ao HIV em mulheres contaminadas no contexto doméstico, é necessário analisar as relações conjugais, enquanto cenário particular de estratégias de poder de gênero. A exposição dos dispositivos que legitimam essa desigualdade leva à crítica dos laços conjugais como pacto amoroso, e se esboça uma visão frente às diversas formas contratuais de relação entre homens e mulheres.

E, a partir daí, há que se indagar em que medida esta desigualdade, mais do que efeito da discriminação externa, é forma subjetiva de auto-exclusão como efeito complexo de uma construção: uma imagem de si que as limita nas práticas sociais e em outras práticas de si.

Segundo Heller (1992), "a vida cotidiana é a vida de todo homem inteiro, ou seja, o homem participa na vida cotidiana com todos os aspectos da sua individualidade, de sua personalidade. Nela colocam-se em 'funcionamento' todos os seus sentidos, todas as suas capacidade intelectuais, suas habilidades 
manipulativas, seus sentimentos, paixões, idéias, ideologias...", ao que conclui afirmando que "a vida cotidiana não está fora da história, mas no "centro" do acontecer histórico: é a verdadeira essência da substância social"(p.17).

Partindo deste pressuposto, este estudo visa, a partir de relatos sobre histórias de vida, por mulheres soropositivas para o HIV, a busca de percepções, sentidos e significados do "ser mulher que vive com o HIV/Aids", para discutir o papel feminino no contexto da infecção, e sua percepção das experiências vividas em suas relações cotidianas, objetivando a compreensão das situações que elas enfrentam e que interferem no enfrentamento, auto-cuidado e adesão ao tratamento.

Assim, o objetivo principal desta pesquisa, é: conhecer a história de risco para a infecção pelo HIV/AIDS e a experiência com a soropositividade entre mulheres que foram contaminadas no contexto de relacionamentos estáveis, visando fortalecer e contribuir para estratégias preventivas e para o aperfeiçoamento dos serviços voltados para a saúde da mulher no âmbito da epidemia de HIV/AIDS. 


\section{1 - Referencial Teórico Metodológico: Representações Sociais}

A noção de representação se evidencia na produção das mais diversas áreas do conhecimento nas Ciências Humanas e Sociais, mantendo suas especificidades em cada disciplina. Segundo Spink (1995):

"Encontramo-la, no mais das vezes, sempre que a reflexão se debruça sobre o poder das idéias de criar um universo simbólico compartilhado que possibilita (e orienta) a ação no cotidiano; sobre seu poder em sustentar identidades grupais e em institucionalizar determinadas práticas sociais" (p. 02).

Todavia, para a Psicologia Social, o estudo das representações sociais proporcionou um campo estruturado. Nesta perspectiva, as representações são essencialmente dinâmicas; são produtos de condicionamentos tanto históricos como do aqui-e-agora e construções que têm uma função de orientação: "são conhecimentos sociais que situam o individuo no mundo e, situando-o, definem sua identidade social - o seu modo de ser particular, produto do seu ser social.” (Spink, 1995, p.8). Além deste aspecto, o conteúdo das representações é essencialmente social, sendo produto e produtor da ordem simbólica. Assim, as representações "são valorativas antes de serem conceituais; e respondem a ordens morais locais, ficando, como tal, prenhes de afeto; sendo conhecimentos práticos, estão orientadas para o mundo social, fazendo e dando sentido às práticas sociais” (idem, p. 09).

Deve-se ao psicólogo francês Serge Moscovici, no inicio da década de 60, o desenvolvimento do conceito de representação social, demonstrando a indissociação 
entre individuo, grupo e sociedade, além de uma critica à psicologia sobre o conhecimento fragmentado do homem. Seus estudos partiram de uma visão cognitivista no qual as representações sociais eram tidas como um saber desenvolvido no cotidiano das relações sociais, onde os grupos de referência exerceriam fortes influências na construção individual destas representações.

A partir dos diversos estudos sobre o tema, Jodelet (apud Sá, 1989) propôs o seguinte conceito, sobre o qual parece haver um consenso entre os pesquisadores:“...uma forma de conhecimento, socialmente elaborada e partilhada, tendo uma visão prática e concorrendo para a construção de uma realidade comum a um conjunto social”(p.32).

De acordo com Moscovici, o propósito de todas as representações é o de transformar algo não familiar em familiar. $\mathrm{O}$ estranho provoca o medo da perda dos referenciais habituais, do senso de continuidade e de compreensão mútua. Uma realidade social é criada apenas quando o novo ou não familiar vem a ser incorporado aos universos consensuais. Aí, operam os processos pelos quais ele passa a ser familiar, tornando-se socialmente conhecido e real: a ancoragem e a objetivação (Sá, 1989).

A ancoragem consiste na integração cognitiva do objeto representado sejam idéias, acontecimentos, pessoas, relações, etc. - a um sistema de pensamento social preexistente e nas transformações sociais implicadas. Assim, ancorar é trazer para categorias e imagens conhecidas o que ainda não está classificado e rotulado. $\mathrm{O}$ rótulo confere uma afiliação e uma posição em cada matriz de identidade (Lane, 1995). 
Pela objetivação, as noções, idéias e imagens são transformadas em algo concreto, material, que constituem a realidade. Segundo Moscovici, “objetivar é descobrir a qualidade icônica de uma idéia ou ser imprecisos, reproduzir um conceito em uma imagem" (apud Sá, 1995, p.40). Ou ainda, segundo Jodelet, a objetivação consiste em uma operação imaginante ou estruturante, pela qual se dá uma forma - ou figura especifica ao conhecimento acerca do objeto, materializando a palavra (idem).

De acordo com Spink (1995),

"a complexidade do fenômeno decorre da desconstrução, no nível teórico, da falsa dicotomia entre o individual e o coletivo e do pressuposto daí decorrente de que não basta apenas enfocar o fenômeno no nível intraindividual (como o sujeito processa a informação) ou social (as ideologias, mitos e crenças que circulam em uma determinada sociedade). É necessário entender, sempre, como o pensamento individual se enraíza no social (remetendo, portanto, às condições de sua produção) e como um e outro se modificam mutuamente"(p.89).

Fica saliente, assim, a dupla face das representações, como produto e como processo. Enquanto produto, as representações sociais emergem como pensamento estruturado, tendo como elementos constitutivos as informações, imagens, opiniões, crenças, etc. Enfocado enquanto processo, emergem como pensamento constituinte ou núcleos estruturantes, ou seja, a elaboração e transformação das representações sob a força de determinações sociais ou interação social.

Neste sentido, Lane (1995), destaca o papel das comunicações de massa na produção de representações, reproduzindo os dizeres de Moscovici (1989):

“...nossas representações são sociais, não apenas por causa de seu objeto comum ou pelo fato de que elas são compartilhadas. Elas o são igualmente pelo fato de que são produto de uma divisão de trabalho que as marcam de uma certa autonomia. (...) são todas aquelas (pessoas) que se consagram à difusão de conhecimentos científicos e artísticos: médicos, terapeutas, 
assistentes sociais, animadores culturais, especialistas em mídia e em marketing político" (p. 60).

Observa-se, portanto, intercâmbio entre intersubjetividades e o coletivo na construção de um saber que não se dá, conforme colocado por Lane (1995), apenas como um processo cognitivo, mas que contém aspectos inconscientes, emocionais e afetivos tanto na produção como na reprodução das representações sociais.

Com isso, o estudo das representações sociais vem superando a dicotomia entre cognição e emoção. De acordo com Sawaia (1995a), com a perspectiva de que a representação social é intrinsecamente carregada de afeto, a analise da ancoragem e objetivação vem sendo enriquecida com a participação da memória afetivaemocional no pensamento de fundo. Em sua pesquisa sobre a consciência de mulheres faveladas, Sawaia (1995b) detectou um processo onde as emoções, estimuladas pela atividade, reativaram a memória, gerando novas atividades. A partir destes resultados, concluiu que os afetos induzidos pela reativação da memória emocional, colocam o sistema representacional num estado receptivo que lhe permita assimilar ou criar novos elementos que contribuam para sua expressão e transformação.

Também Jodelet (apud Lane, 1995), adverte que as representações devem ser estudadas "articulando elementos afetivos, mentais e sociais e integrando, ao lado da cognição, da linguagem e da comunicação, a consideração das relações sociais que afetam as representações e a realidade material, social e ideal sobre as quais elas vão intervir” (p. 61), avançando para uma concepção do ser humano essencialmente social, condição esta para que ele se individualize e particularize. Segundo Jodelet, “ não é possível conhecer o ser humano sem considerá-lo inserido 
numa sociedade, numa cultura, num momento histórico e em dadas condições políticas e econômicas”.

Partindo do pressuposto segundo o qual o individuo é concebido como um todo, em que o singular e a totalidade social são indissociáveis, e o sujeito, ao elaborar e comunicar suas representações, recorre a significados socialmente constituídos e de sentidos pessoais decorrentes de suas experiências cognitivas e afetivas, Lane (1995), ressalta a importância do conceito de representação social como dado empírico do qual se parte para uma análise dialética que permite conhecer concretamente a consciência, a atividade e a identidade de sujeitos situados social e historicamente.

O caráter dinâmico do processo de representações sociais forneceria a segurança necessária de um dado empírico que, necessariamente mantém vínculos tanto com as condições sociais (grupos, comunicação de massa, etc) como as condições individuais de existência, permitindo assim, procedimentos de análises que aprofundem o conhecimento de psiquismos singulares, constituídos em suas multideterminações.

Sawaia (1995) ressalta ainda a importância de conjugar o conceito de representação ao conceito de ideologia. Heller, em 1985, já falava da interpretação ideológica dos sentimentos, onde cada momento histórico tem sentimentos dominantes e o mundo burguês atua sobre os sentimentos de forma ideológica. Cita a vergonha e a culpa quando impostas por uma autoridade externa, gerando subalternidade e conseguinte instrumentalização de si. De acordo com a autora, foi a interiorização não só das normas como de sanções, em nível social e emocional, que fez o homem aceitar a humilhação como natural (apud Sawaia, 1995). 
Dejours (1986), também relaciona vergonha à ideologia ao estudar a saúde do proletariado e observar a resistência em falar da própria doença e sofrimento pelo significado do ato vergonhoso que lhes atribuíam, em decorrência dos valores do capitalismo.

O termo ideologia é usado por Moscovici para o conjunto de representações que se torna partilhado coletivamente pela reificação por meio de sua apropriação por órgãos estatais ou escolas do pensamento e não pelo consenso e interação, subordinando o segundo ao primeiro. Ainda que Moscovici tenha captado o caráter reificante da ideologia como discurso estruturado e estruturante que tende a impor a ordem estabelecida como natural, não a vê como imposição mascarada ajustada às estruturas de poder. Na verdade, segundo Sawaia (1995), as representações de um individuo não são independentes, relacionam-se a outros sistemas de representação e expressam um discurso sobre a sociedade inteira.

Sendo assim, a relação estabelecida entre os homens e entre eles e o mundo social são objetivados por instituições, as quais tem por função manter uma ordem social. A institucionalização da atividade humana se dá quando uma ação se torna habitual e o individuo é capaz de lhe atribuir um sentido, que passa a fazer parte de seu acervo de conhecimento sobre a realidade. Desta forma, as instituições estabelecem padrões de conduta e controlam ações, adquirindo historicidade e objetividade, acentuando o caráter dialético na constituição social do mundo: o homem torna-se ao mesmo tempo produtor e produto da realidade.

A articulação dos papéis para a objetivação das instituições contribui para a 
legitimação de um universo simbólico ${ }^{7}$ a ser compartilhado. Tornar algo legitimo significa tornar a realidade válida e justificar suas normas e valores. O universo simbólico legitimado informa ao individuo não apenas o porquê de agir de determinada maneira, mas também o porquê das coisas serem como se apresentam. Desta forma, ao construir uma identidade dentro de um universo simbólico legitimo, o individuo possui uma compreensão de si mesmo, socialmente estável e reconhecida (Berger \& Luckmann, 1985).

Entretanto, segundo estes autores, quando esta ordem e normalidade é quebrada ou ameaçada, ocorrem as dissidências. A conduta dos dissidentes desafia a normalidade da realidade social e questiona as normas e padrões estabelecidos como certos, gerando um processo de culpabilização. Pode ser citado como exemplo de dissidentes, as mulheres soropositivas para o HIV contaminadas no contexto dos relacionamentos estáveis, colocando em cheque o caráter seguro do casamento, abalando uma série de rotinas e certezas acerca da normalidade do cotidiano, além da culpabilização e ameaça a uma ordem estabelecida como normal.

Portanto, o mundo da vida cotidiana é tecido por significados, construídos pelas ações humanas e passíveis de interpretações. Não existe uma realidade à priori $^{8}$, mas que toda a realidade é uma representação, reapropriada e reconstruída pelos indivíduos, integrado a seu sistema de valores e condicionado à história e as relações sociais.

\footnotetext{
${ }^{7}$ Segundo Berger \& Luckmann (1985), o universo simbólico é concebido como matriz de todos os significados socialmente objetivados e subjetivamente reais (p.32), ou seja, para seu entendimento é necessário a compreensão de como este universo foi produzido através da investigação do seu caráter histórico.

${ }^{8}$ Para Sawaia (1995:75), a realidade é um fenômeno humano e histórico e o homem é um ser significante que age sobre o mundo e o interpreta, transformando-o ao mesmo tempo em que é impregnado de objetividade, que é a objetividade da práxis humana num arranjo social em que os grupos lutam por se afirmar e dominar.
} 
Com base nestes pressupostos, optou-se, nesta pesquisa pela análise das representações por acreditar que permitem compreender, por meio dos discursos produzidos pelo senso comum, de que forma se dá a atribuição do significado da soropositividade e de que forma influenciam na (re)construção da identidade destas mulheres, na tentativa de compreender como constroem seu mundo e a si própria por meio das interações estabelecidas com a sociedade.

A análise tomará, como parâmetro, o caráter complexo das representações sociais, como produto e como processo, conforme colocado por Spink (1995). Desta forma, a análise sobre as representações sociais da soropositividade ao HIV no cotidiano das mulheres contaminadas no contexto de relacionamentos afetivos estáveis, na qualidade de produto, buscará desprender quais seus elementos constitutivos, as informações e opiniões que estruturam os discursos e condicionam a sua produção, devendo tais análises serem balizadas pelo contexto social do qual surge, circula e se transforma. Na qualidade de processo procurará compreender quais os fatores sociais determinantes para a sua elaboração e transformação na interação social, levando em conta a posição ocupada pelos indivíduos. No entanto, produto e processo estão inevitavelmente imbricados nesta pesquisa.

\section{2 - Participantes}

Foram entrevistadas 10 (dez) mulheres soropositivas para o HIV, contaminadas pelo parceiro no contexto de relacionamento estável, atendidas no AMIGO - Ambulatório de Moléstias Infecto-Contagiosas de Ginecologia e Obstetrícia, do Hospital das Clínicas da Faculdade de Medicina de Ribeirão Preto, da 
Universidade de São Paulo.

Observa-se que, como investigação levada a termo em bases qualitativas, este trabalho não privilegia as possibilidades de generalização, embora não deixe de ser lembrada uma citação da Torah sobre a reflexão de uma única vida conter toda a humanidade.

\section{3 - Instrumento para Coleta de Dados}

A abordagem qualitativa, por incorporar uma dimensão integral e favorecer um aprofundamento do tema, apresenta-se mais adequada ao desenvolvimento deste estudo. Dentro desta abordagem foi utilizada a técnica de entrevista aberta para coleta da história de vida.

Sob o ponto de vista psicológico ou sociológico, Bogdan e Biklen (1997) relatam que a história de vida oferece condições para reconstituir as posições, estágios e formas de pensar dos indivíduos ao longo da sua vida, enfatizando o papel das organizações, acontecimentos marcantes e outras pessoas com influencias significativas na definição de si próprios e suas perspectivas sobre a vida.

Denzin (1989) concorda que a história de vida evoca a experiência de uma pessoa, grupo ou organização e a forma como estas experiências são interpretadas por este individuo, acentuando ainda três características básicas: é a história da própria pessoa; a situação social e cultural em que o sujeito está inserido e; a seqüência de experiências passadas e situações na vida do sujeito.

Para Minayo (1998), a história de vida é um instrumento privilegiado para se interpretar o processo social a partir das pessoas envolvidas, na medida em que se 
consideram as experiências subjetivas como dados importantes que falam além e através delas.

A história de vida verbalizada pelos participantes, segundo Fraser (citado por Minayo, 1998), constitui uma tentativa de revelar o ambiente dos acontecimentos que fazem parte da experiência de determinado grupo social. Visa descobrir o ponto de vista e as motivações dos participantes voluntários ou involuntários na História, portanto, protagonistas dos feitos sociais.

\section{4 - Procedimento de Coleta de Dados}

As entrevistas foram realizadas pela pesquisadora, em sala adequada do AMIGO, no dia agendado para retorno médico, antes ou depois da consulta. Ocorreu um encontro com cada sujeito, com tempo de duração variando entre duas e três horas.

Após explicar o objetivo da pesquisa, tendo a aquiescência do sujeito, era solicitado que contasse a história de sua vida, desde do nascimento até a atualidade.

As entrevistas foram gravadas em fita cassete, com a devida autorização escrita das entrevistadas e, em seguida, transcritas na íntegra para possibilitar a análise dos dados.

\section{5 - Procedimento de Análise dos Dados}

A analise dos dados é um processo contínuo que tem inicio durante o primeiro contato com o entrevistado, quando o investigador segue a pista dos temas emergentes, tendo sequiência na escuta das fitas e transcrições, que trazem o 
desenvolvimento de conceitos e proposições que dão o sentido inicial aos dados.

A análise dos conteúdos das entrevistas foi realizada com base em Categorias determinadas a partir dos temas suscitados nas entrevistas e processada em uma série de etapas, de acordo com a proposta de Figueiredo et al (1993), conforme o esquema a seguir:

QUADRO 2 - Etapas do Procedimento de Análise de Conteúdo do material transcrito nas notações em grupo.

\begin{tabular}{|c|c|}
\hline \multicolumn{2}{|c|}{ TRANSCRIÇÃO DO MATERIAL } \\
\hline PRIMEIRA FASE & A. Leitura Inicial \\
(Sessões/Sujeitos) & B. Marcação \\
& C. Corte \\
& D. Primeira Junção* \\
& E. Notação \\
& Frganização e Primeira \\
& Síntese \\
\hline SEGUNDA FASE & SEGUNDA JUNÇÃO** \\
(Conteúdos) & G. Leitura Inicial \\
& H. Organização \\
& I. Notação \\
& J. Redação Final \\
\hline
\end{tabular}

* Conteúdos relacionados a várias Categorias, no mesmo sujeito ou mesmo grupo.

** Conteúdos de vários sujeitos ou vários grupos, em uma mesma Categoria.

\section{- Primeira Fase:}

As entrevistas foram analisadas individualmente e a junção concentrou conteúdos comuns dentro de cada discurso. Assim, cada discussão foi transcrita e estudada em função de cada entrevista realizada, devendo se referir às questões particulares de cada indivíduo. Compreenderá as seguintes fases: 
A. Leitura Inicial: Nessa primeira leitura, foram identificados alguns pontos preliminares, ligados às Categorias, realizando anotações à respeito de aspectos relacionados à situação da entrevista, como rapport, dificuldades de interação, disponibilidade e seu estado afetivo.

B. Marcação: Foram selecionados alguns trechos da entrevista que corresponderam às Categorias pré-estabelecidas, além de outros conteúdos também considerados importantes.

C. Corte: Os trechos selecionados foram retirados do texto.

D. Junção: Os trechos selecionados foram agrupados; ou seja, todas as anotações de uma mesma entrevista foram dispostas em protocolos de análise.

E. Notação: Foram feitas observações marginais sobre os trechos, com o objetivo de localizá-los na literatura e no contexto do grupo.

F. Discussão: As observações foram discutidas para que se pudesse fazer a segunda junção, onde serão agrupados os trechos de todas as entrevistas em relação a uma mesma categoria.

\section{- Segunda Fase}

Nesta etapa, as entrevistas não foram consideradas individualmente e a junção se referiu a conteúdos comuns a todas entrevistas. Assim, as junções realizadas na etapa anterior foram agrupadas e estudadas em função da equivalência de conteúdos, referindo-se às questões comuns, dentro de cada categoria. Seguiu as seguintes fases:

G. Leitura Inicial: Foi realizada uma leitura para que se pudesse identificar os 
trechos cujos conteúdos são comuns, dentro de cada Categoria.

H. Organização: Esses trechos foram, então, agrupados e classificados em subcategorias com base em protocolos especiais.

I. Notação: Quando necessário, foram ampliadas as observações marginais relacionando-as às subcategorias.

J. Discussão Final e Redação: Foi realizada a redação definitiva, baseada nos resultados obtidos através da análise de conteúdo, relativo às categorias que surgiram durante as entrevistas.

\section{6 - Aspectos Éticos}

Este estudo foi realizado considerando-se os aspectos éticos pertinentes a pesquisas envolvendo seres humanos, tendo sido submetido à avaliação pela Comissão de Ética Médica do HCFMRP - USP.

Foi solicitado o Consentimento Informado dos participantes, cujo modelo foi elaborado de acordo com a "Resolução n" 196/96 Sobre Pesquisa Envolvendo Seres Humanos" (Brasil: Ministério da Saúde, Conselho Nacional de Saúde, 1996).

Este documento constituiu de solicitação aos pacientes para participação no estudo, após serem informados sobre os objetivos e procedimentos da pesquisa e obtida a aquiescência - escrita e assinada - para participação e gravação da entrevista, além de ser assegurado o anonimato. Foram informados ainda que este consentimento garantia ao entrevistado o direito de interromper sua colaboração na pesquisa a qualquer momento, caso julgasse necessário, sem que isso implicasse em prejuízo em seu atendimento no serviço. 


\section{3 - RESULTADOS E DISCUSSÃO}

\section{1 - Trajetória de Vida}

Com o objetivo de facilitar a compreensão dos acontecimentos ocorridos na vida destas mulheres, serão apresentadas no Anexo 1, as histórias de vida resumidas, á partir de fragmentos dos discursos.

Optou-se por não incluir as entrevistas na íntegra devido ao compromisso estabelecido de sigilo, mesmo desprovendo-as de quaisquer identificação nominal ou numérica.

\section{2 - Caracterização das Participantes}

Este grupo de 10 entrevistadas tem o perfil da tendência da epidemia.São mulheres jovens, em sua maioria donas de casa, que foram contaminadas, via sexual, por seus maridos ou parceiros estáveis. Mulheres que não se perceberam vulneráveis, principalmente porque cumpriam o papel que se espera delas - o amor monogâmico e dedicação ao lar e a família.

A maioria só teve conhecimento do diagnóstico soropositivo ao ficarem grávidas, ao iniciarem o pré-natal.

Estas mulheres tem em média 26 anos, com idade variando de 21 a 35 anos, com tempo de diagnóstico de 6 meses à 10 anos $(\mathrm{x}=4,1)$, o que nos mostra que foram infectadas muito jovens, algumas ainda na adolescência. Apenas $30 \%$ se 
encontra em fase sintomática da infecção, o que nos leva a observar o aumento da longevidade após a introdução dos anti-retrovirais. Nesta amostra, 80\% faz seguimento com medicamentos, $10 \%$ faz seguimento sem medicamentos e $10 \%$ não faz seguimento, tendo parado por conta própria. No entanto, muitas estão retornando ao Serviço de Saúde por se encontrarem gestantes e, portanto, sentem necessidade de reiniciar o tratamento na tentativa de evitar a transmissão vertical.

\section{- Perfil Sócio-Econômico}

O perfil sócio-econômico destas mulheres nos remete aos estudos sobre a feminização da epidemia. A maioria vive em situação conjugal, sendo $30 \%$ casadas legalmente e $40 \%$ casadas consensualmente, com tempo de relacionamento mínimo de 3 anos e máximo de 10 anos $(x=5,6)$.

Nenhuma destas mulheres foi além do Ensino Fundamental, sendo que 80\% nem chegaram a completá-lo. Em relação a ocupação anterior e ocupação atual, não foi encontrada diferença significativa, visto que $70 \%$ sempre foram donas de casa dedicadas ao lar, filhos e marido; $30 \%$ tem como ocupação o trabalho de faxineira, escolhido por não ter vínculos que desviem sua atenção do lar. Portanto, a maioria não possui renda própria, tornando-se assim, dependente do marido.

Entretanto, neste caso, a dependência econômica não parece interferir na adesão ao tratamento, visto que os medicamentos são custeados pelo governo.

No caso da aderência ao tratamento, ocorre mais em decorrência da necessidade de se manter com saúde para "cuidar do outro", principalmente dos filhos, do que em benefício próprio e, quando gestantes, pela necessidade de prevenir 
a transmissão vertical.

\section{- Filhos}

Nesta amostra, todas as entrevistadas têm filhos. A média de filhos é de 2,9, variando entre 1 e 5 filhos. Com exceção de um caso, cujos filhos gêmeos estão em uma Casa de Apoio, todos vivem com a mãe.

Do número total de filhos, $45 \%$ nasceram antes do diagnóstico, o que aponta um número considerável - 55\% - de gestações após a mãe saber de sua soropositividade, ainda que apontem como fonte de medo e angústia, a contaminação do bebe (9\%), medo de não criar os filhos $(9 \%)$ e medo dos filhos não negativarem (27\%). Pode-se observar aqui a confiança depositada no tratamento para prevenção e baixas estatísticas da transmissão vertical, citadas por elas, que, se não consegue extinguir o medo, serve como esperança. Entretanto, o número de filhos com sorologia positiva ou ainda em seguimento, corresponde quase a metade da amostra (45\%), proporção muito alta, quando se sabe que o AZT na gravidez diminui essa proporção para menos de $10 \%$ dos recém-nascidos. No entanto, é preciso considerar a época em que ocorreram estes nascimentos, visto ser a terapia de prevenção vertical relativamente nova.

\section{- Vulnerabilidade}

A grande maioria das mulheres não se percebe vulnerável ao HIV. Principalmente, aquelas que se encontram em relacionamento estável, onde acreditam existir amor, respeito e confiança entre o casal. Como consequiência trágica, são vitimas da infecção pelo parceiro. 
Nessa amostra, todas as mulheres acreditavam estar seguras, não imaginando que pudessem ser contaminadas, afinal, tinham parceiro único, "não saíram para procurar na rua". Ainda em consequiência dos erros de avaliação no início da epidemia, acreditando não pertencer a nenhum "grupo de risco", foram surpreendidas pela contaminação.

Depois de constatada a infecção, algumas passam a levantar comportamentos do parceiro que poderiam ter dado uma indicação, suscitado desconfianças, como o uso de drogas, saídas noturnas e até mesmo suspeita de bissexualismo. Para elas, isso as torna cúmplices da contaminação, pois não fizeram nada para evitar.

\section{- Relacionamento Afetivo}

Atualmente, a maioria destas mulheres vivem relacionamentos estáveis, sendo $70 \%$ casadas legal ou consensualmente, $20 \%$ separadas com parceiro eventual e $10 \%$ separadas sem parceiro e vida sexual inativa. No entanto, todas foram contaminadas em relacionamentos estáveis. Apenas $40 \%$ mantiveram o relacionamento com o parceiro contaminador e $70 \%$ estão vivendo novos relacionamentos. Este número não quer dizer que houve ruptura no relacionamento após o conhecimento do diagnóstico. Isso só ocorreu em 20\% dos casos, sendo o restante conseqüência de morte do parceiro (20\%), abandono pelo parceiro (10\%) e $20 \%$ terminaram o relacionamento sem estar ciente do diagnóstico, o que só ocorreu tempos depois.

Embora no momento da descoberta do diagnóstico exista um grande desespero $(30 \%)$, com vontade de morrer $(30 \%)$, a revolta em relação ao parceiro 
contaminador (20\%), não persiste no decorrer do tempo, sendo seguida por sentimentos de aceitação, inevitabilidade, negação e total "absolvição" do parceiro em alguns casos. A maioria da amostra refere que o amor pelo parceiro continua igual $(50 \%)$ ou ainda aumentou (30\%), com mais união e cumplicidade gerada pela situação de enfrentamento à doença.

Um dado interessante se refere à soropositividade do parceiro atual, onde apenas 30\% são comprovadamente soropositivos, sendo estes os parceiros contaminadores que mantiveram o relacionamento. Chama atenção os casais discordantes, ou seja, casais onde ela é positiva e o parceiro sabidamente negativo (20\%), embora mantenham vida sexual ativa no mínimo há 3 anos. E ainda, o fato de que em $50 \%$ dos casos, o status sorológico do parceiro é desconhecido pela recusa dele em fazer o teste, seja pela crença na inevitabilidade da contaminação ou pela negação da doença pela falta de sintomas aparentes. Esta não-contaminação masculina tem sido motivo de investigação científica, sendo reportada basicamente às diferenças anatômicas entre os gêneros e grau de exposição ao HIV.

Em relação aos motivos relatados pelos parceiros para sua contaminação, $70 \%$ alegam ter sido por via sexual, $20 \%$ pelo uso de drogas injetáveis e $10 \%$ alegam não saber.

Mesmo sabendo da soropositividade da parceira, muitos se recusam a usar o preservativo ou fazem uso assistemático, por motivos que vão desde não gostar de usar, até os que preferem se entregar e compartilhar o destino dela "por amor".

Para as mulheres, o fato do parceiro ser positivo ou não, afeta de forma significativa a decisão do uso de preservativo. No caso dele ser negativo, ela obtém os recursos necessários para a exigência do uso pela necessidade de protegê-lo. 
$\mathrm{Na}$ verdade, estas mulheres, mesmo tendo conhecimento da necessidade do uso de preservativo após a contaminação, evitando o agravamento da infecção, seguem em sua vida sexual tendo os mesmos problemas de negociação do sexo mais seguro. Após a contaminação, $90 \%$ das mulheres continua tendo vida sexual ativa, a maioria mantendo o desejo (80\%), o prazer $(90 \%)$ e a freqüência sexual $(80 \%)$ iguais à antes da contaminação, com poucas alterações nos aspectos relacionados à vida sexual. No entanto, apenas $40 \%$ relataram passar a fazer uso adequado do preservativo apesar das orientações médicas.

O uso de preservativo antes da contaminação só foi relatado por $10 \%$ da amostra. Os motivos alegados para não usar foram, principalmente, "não tem porquê usar" (40\%), o fato de ser casada $(30 \%)$ e $20 \%$ relataram não saber os motivos. Após a contaminação, observou-se um aumento de apenas $30 \%$ do uso, sendo alguns dos motivos para a falta de uso: não tem porque usar, já que ambos são positivos (30\%); nem sempre tem disponível (10\%), não sabe (10\%). Já a aderência ao uso se deu principalmente devido ao status soronegativo do parceiro e o receio de contaminá-lo.

\section{- Enfrentamento}

Em relação ao enfrentamento à doença, a maioria prefere manter o resultado em sigilo, tendo como único confidente o parceiro ( $40 \%$ ), de acordo com depoimentos, a única pessoa que tem o direito de saber. Isso se deve principalmente por medo do preconceito e pela preservação dos filhos. Observa-se, contudo, um silêncio envolvendo essa questão, ou seja, elas acreditam que mais pessoas da família saibam, mas isso não é admitido por nenhum dos lados, fingindo não saber. Mesmo 
com o próprio parceiro parece existir um pacto de silencio, ambos sabem, mas não se fala nisso. O falar significa trazer para a vida cotidiana a sombra da AIDS, portanto é melhor ignorar sua existência. As perguntas, quando existem, são feitas de modo amplo, sem sequer falar o nome da doença, muitas vezes tratada por "o problema".

A procura pela religião aumentou bastante após a contaminação, surgindo como forte meio de enfrentamento. Antes do diagnóstico essa amostra era constituída por $70 \%$ de católicas, $20 \%$ de evangélicas e $10 \%$ não tinha religião. Após o diagnóstico, aumentou a procura e freqüência à igreja, sendo que 50\% permanecem católicas, embora se digam pouco praticantes. O número de evangélicos aumentou para 50\%, todas bastantes inseridas nas comunidades religiosas, alegando receber grande conforto e esperança de cura. Acreditamos que, desde que estas crenças não prejudiquem ou interrompam o tratamento, a fé e esperança de cura adquirida, contribuem para uma melhora no quadro geral da paciente. Portanto, em um primeiro momento, a manutenção dessa crença, ainda que nos pareça um tanto exagerada, pode ser benéfica para a paciente e para a adesão ao tratamento.

À partir da realidade soropositiva, os planos de vida destas mulheres passam a existir em função dos filhos (50\%). Observou-se que para algumas o futuro não mais existe, se atem em viver um dia atrás do outro, sem planos (20\%) ou esperando a morte chegar (10\%).

Apesar de se encontrarem em situação crítica, o papel de "cuidadora" permanece como sendo o seu maior referencial. Enquanto tiverem de quem cuidar vai existir razão para lutar e sobreviver. Até mesmo quando procuram o serviço médico, isso se deve mais por estar gestante - cuidado com o bebê - ou pela 
necessidade de se manter bem de saúde para cuidar dos filhos. Sua aspiração de tempo de vida passa a ser o que for necessário até que seus filhos estejam "criados".

\section{3 - Categorias Temáticas Enunciadas}

Da análise exaustiva das histórias de vida transcritas, seguindo os passos acima descritos, derivou as seguintes categorias que constituirão a análise fundamental desta pesquisa:

\section{A - A soropositividade no Cotidiano da Mulher}

- Diagnóstico

- Convivendo com a soropositividade

- Estigma, discriminação e preconceito

- Rede Social

- Naturalizando a AIDS

\section{B - Relações Afetivo-Sexuais}

- Iniciação amorosa-sexual

- Manutenção/Rompimento do Primeiro Casamento

- Sentimentos decorrentes da Contaminação

- Sorologia do parceiro atual

- Novo relacionamento após a contaminação

- Representações sobre o amor

- As "lógicas" da prevenção

\section{C - A Prática em Saúde no Discurso da Mulher Soropositiva}

- Relação Profissional de Saúde - Paciente - Serviço de Saúde 
- Devolução do Diagnóstico Soropositivo

-Equipe Multidisciplinar

\section{A - A Soropositividade no Cotidiano da Mulher}

\section{- Diagnóstico}

O recebimento do diagnóstico soropositivo para o HIV acarreta, no primeiro momento, uma destruição significativa em todos os aspectos da vida do indivíduo, modificando a estrutura de sua personalidade, seus contatos com o mundo e seus valores. Entretanto, para a mulher envolve situações peculiares, como gravidez e maternidade, tornando este momento ainda mais complexo. O ser mãe e estar com AIDS constitui uma situação ambivalente, permeada por culpa, ansiedade e medos.

Conforme pode ser observado no Quadro 3, as mulheres do grupo estudado tiveram conhecimento do diagnóstico soropositivo na década de noventa, período este que corresponde, de acordo com os dados epidemiológicos, ao fenômeno de feminização da epidemia.

O momento do diagnóstico para a maioria destas mulheres ocorreu durante o pré-natal ou parto. A escolha do pré-natal como momento de detecção da sorologia para o HIV, visando a prevenção da transmissão vertical, tem gerado inúmeras discussões éticas, morais e políticas, impondo novos desafios à assistência a maternidade (Barbosa \& Lago, 1997). É indiscutível a adequação da medida, visto que as terapêuticas disponíveis demonstram uma redução no risco da transmissão materno-infantil para 8\% (Matida \& Miranda, 2000). No entanto, esta medida deixa 
claro que a preocupação ocorre muito mais em função dos filhos que estão gerando do que com a mulher que gera. É preciso considerar que, de acordo com as expectativas culturais, a gravidez seria o momento de realização plena da feminilidade, em consonância com o "destino" biológico da mulher. A reação de saber-se portadora neste momento pode ter um alto custo psicológico, ocasionado pela ruptura da idealização social que desfruta esta função, interiorizada desde a infância, encontrando no papel de esposa e mãe sua identidade. Portanto, é preciso estabelecer, como beneficiários desta estratégia, não apenas o bebê, mas também a mulher, analisando as conseqüências sócio-emocionais desta estratégia, propiciando cuidados que envolvam tanto a saúde física como a mental.

Quadro 3 - Demonstrativo da Situação no Recebimento do Diagnóstico

\begin{tabular}{|c|c|c|c|}
\hline Sujeito & Ano & Motivo & Reação Inicial \\
\hline 01 & 1996 & $\begin{array}{l}\text { Adoecimento } \\
\text { Companheiro }\end{array}$ & Negação \\
\hline 02 & 1999 & Pré-Natal & $\begin{array}{c}\text { Compto. Auto-destruitivo } \\
\text { Culpa Companheiro }\end{array}$ \\
\hline 03 & $\begin{array}{l}1991 * \\
1995\end{array}$ & $\begin{array}{c}1^{\circ} . \text { Pré-Natal } \\
2^{\circ} \text {. Adoecimento }\end{array}$ & $\begin{array}{c}\text { Negação } \\
\text { Desejo de Morte }\end{array}$ \\
\hline 04 & 1992 & $\begin{array}{l}\text { Adoecimento } \\
\text { Companheiro }\end{array}$ & Negação \\
\hline 05 & 1999 & $\begin{array}{l}\text { Adoecimento } \\
\text { Companheiro }\end{array}$ & Desespero \\
\hline 06 & 1998 & Pré-Natal & $\begin{array}{c}\text { Revolta } \\
\text { Incredulidade }\end{array}$ \\
\hline 07 & 1995 & Parto & Desespero \\
\hline 08 & 1998 & Adoecimento & Desespero \\
\hline 09 & 1995 & Parto & Desestruturação \\
\hline 10 & 1999 & Pré-Natal & $\begin{array}{c}\text { Desespero } \\
\text { Incredulidade }\end{array}$ \\
\hline
\end{tabular}

* Paciente teve dois diagnósticos 
Os motivos que levaram estas mulheres a serem diagnosticadas - pré-natal, parto ou adoecimento do companheiro - demonstram que sua relação com a saúde não tem se operado de forma efetiva, tendo como conseqüência o diagnóstico do HIV tardio, menor eficácia das intervenções e diminuição do tempo de sobrevida. Elas vivem seu cotidiano marcado pelos valores e padrões culturais que colocam a mulher como responsáveis por uma serie de papéis sociais: mães, esposas, filhas, profissionais, entre outros. Esta multiplicidade de papéis e a ênfase na sua função de "cuidadora", terminam por fazer com que negligenciem os cuidados com a sua saúde. Além disso, devido ao pouco ou nenhum acesso à informação e serviços, a mulher "comum", a dona de casa, mãe de família, vem sendo negligenciada pelos programas de assistência. Uma série de fatores concorre para que isso ocorra, dentre eles a própria divisão social do trabalho que, em nossa sociedade designa à mulher a função doméstica, o espaço interno, o que faz com que grande parte de sua relação com o mundo externo seja mediatizado pelo homem, com perdas quanto à autonomia e auto-determinação. Ao procurar assistência médica, ainda correm o risco de serem diagnosticadas erroneamente, pois os sintomas iniciais comuns à AIDS e a tantas outras doenças, como fadiga, perda de peso, insônia, etc - no caso da mulher, tem mais probabilidade de ser entendido como fator psicológico. Segundo estas autoras, isto pode ser compreendido como "conseqüência de uma relação de saúde com o corpo feminino, onde este é percebido a partir de sua função reprodutiva, que passa a assumir prioridade sobre as demais, inclusive com a desqualificação e desatenção frente a algumas queixas” (Matida \& Miranda, 2000, p.168).

Nos relatos que seguem foram apreendidos alguns sentimentos decorrentes do momento da recepção do diagnóstico positivo para o HIV. É importante ressaltar 
que, apesar do espaço de tempo decorrido entre este momento e o dia da entrevista, seu resgate através dos relatos emergiram carregados de emoção, muitas vezes acompanhados por choro. A ênfase e emoção colocada neste momento, corroboram com estudos que enfatizam a forma como é dado o diagnóstico como primordial para a maneira como a nova condição é incorporada ( Figueiredo \& Ribeiro,1996).

O sujeito 01 recebeu o diagnóstico soropositivo aos 18 anos, em decorrência do adoecimento do companheiro. Estava grávida do primeiro filho, que morreu aos 4 meses de vida em decorrência da AIDS:

"Foi muito duro porque eu fiquei sabendo na minha primeira gravidez. Eu fiquei com medo e guardei só pra mim mesmo, não falei pra ninguém. É que tem gente que discrimina, tem esse negócio do nojo... Assim, eu não falei pra ninguém, nem pro médico do pré-natal. Então, eu pus a vida dele (o filho) em risco, se eu tivesse feito tratamento ele não teria nascido com isso.” ( Sujeito 01)

É um discurso bastante rico em conteúdos - negação, fragmentação da ciência médica, culpabilização - e demonstrativo dos sentimentos das mulheres que passam pelo conflito de ser mãe e estar com AIDS.

O ser humano, de uma forma geral, quando se encontra em situação onde sua integridade é ameaçada, utiliza-se de mecanismos de defesa para proteger-se, que podem apresentar-se de forma consciente ou inconsciente. No discurso do sujeito 01, o medo do preconceito, da discriminação e os estereótipos formados em torno da doença interferiram diretamente na sua atitude frente ao diagnóstico: o silêncio como forma de proteção. Esta negação também se encontra presente nos discursos dos sujeitos 03 e 04 :

"Na época, quando recebi o resultado, eu não liguei não, não dei muita importância, mas depois...” (Sujeito 03). 
"Quando eu recebi esse diagnóstico eu era muito criança, ainda tinha 15 anos. Então você não pensa. Porque eu nem sabia que existia isso. Eu não tinha informação. Aí, quando completei 20 anos, aí fui começar a ver as coisas direito. Mas aí eu já estava acostumada porque eu ia no médico todo mês. Eu fiquei muito assustada. Na hora eu não me assustei porque eu me sentia muito bem, eu não tinha nada." (Sujeito 04).

Embora não tenham dado importância ao diagnóstico inicial, elas agiram de forma diferente. A negação, no caso do sujeito 03 , fez com que ela não aderisse ao tratamento, o que só aconteceu quatro anos depois quando, ao ser internada com meningite, recebeu outro diagnóstico positivo. A falta de adesão ao tratamento fez com que surgissem doenças oportunistas. Assim, podemos afirmar que a negação consiste em um dos mais lesivos mecanismo de defesa, uma vez que retira toda a possibilidade de assistência.

No caso do sujeito 04, embora ela negasse a infecção no seu dia-a-dia, aderiu ao tratamento, comparecendo às consultas agendadas. $\mathrm{O}$ fato de sentir-se muito bem, embora portadora de um vírus que destrói, faz com que subestime a situação em sua vida cotidiana, embora acate a ordem médica de tratamento. A negação, neste caso, se aproxima de uma falsa incerteza. Ela sabe que tem o vírus, mas reluta em entrar em contato com essa realidade, que além de ser dolorosa, impõe um novo direcionamento em sua vida. Transparece, assim, a complexidade contextual da AIDS, através das ambivalências de respostas, traduzidas pelas contradições e incoerências dos movimentos do ser humano.

Retomando o relato do sujeito 01, outro ponto evidente é a "subdivisão do conhecimento em especialidades cujos territórios estão estreitamente demarcados, fazendo com que o profissional de saúde veja o paciente sob a ótica da 
especialidade, tratando somente "parte" da pessoa" (Figueiredo \& Ribeiro, 1996, p.5), exemplificado neste caso quando ela tem o clínico, que solicita o exame, e o médico do pré-natal, que cuida da gestação, que não é comunicado do diagnóstico.

Surge ainda, no relato do sujeito 01 , um sentimento de culpabilidade por ter, segundo seu entendimento, agido em benefício próprio, ao proteger-se no silêncio, expondo seu filho à infecção pelo HIV. É o rompimento do contrato natural de responsabilidade (Pereira \& Chaves, 1999) estabelecido na maternidade, onde a mãe deve cuidar de seu filho, que causa esse sentimento de opressão.

Este conflito não emerge apenas pela ocorrência da transmissão do vírus ao filho, mas também é representado pela idéia de abandono compulsório em conseqüência de sua morte. Assim, o medo da morte que surge no momento do diagnóstico, é, na verdade, o medo pelo desamparo dos filhos. É esse medo que, de acordo com os depoimentos a seguir, é o sustentáculo maior para o enfrentamento do diagnóstico e da doença:

"O que todo mundo tem vontade na hora? De morrer, né? Mas aí a gente vai, tem outras coisas pra gente pensar, não é só na gente. Eu não penso só em mim. Eu pensei mais nos meus filhos." (Sujeito 03)

"Quando eu soube que era soropositiva, eu só pensava que eu ia morrer, que não ia mais ver a minha filha.” (Sujeito 06).

"Naquele dia eu quis morrer, aí lembrei da minha filha, pior coisa é criar filho sem mãe." (Sujeito 02).

Segundo Freud apud Ferreira (1994), "no fundo ninguém crê em sua morte, ou, dizendo a mesma coisa de outra maneira, que no inconsciente cada um de nós está convencido de sua própria imortalidade”. No entanto, o diagnóstico positivo 
trouxe para estas mulheres a presença no seu cotidiano, da certeza da morte, traduzido pelo desespero, pela falta de esperança. No momento do diagnóstico, sentindo-se incapazes de lidar com esta ameaça, desejam antecipar sua finitude, como descrito nos depoimentos acima.

Além disso, outro sentimento presente nas narrativas destas mulheres é a perplexidade por estar contaminada. O risco estava longe, não havia nenhum tipo de identificação. O fato de manterem um relacionamento estável, dentro das normas estabelecidas pela sociedade e pela Igreja significava, para elas, distância do risco. No momento do diagnóstico, sentem-se aturdidas:

"Nem imaginava. Sem ter assim, uma história, uma coisa que você soubesse, uma coisa que te levasse a pensar... Eu não tinha idéia. Eu acreditava piamente que eu era negativa e pronto, acabou. Quando você vê, cai uma bomba na sua cabeça. Sei lá, tira o chão, você não sabe pra onde vai, falta o ar, fica naquilo lá até você tentar acordar...” (Sujeito 10).

"Eu sabia que existia a AIDS, mas nem procurava saber porque eu também não sabia que um dia eu ia pegar. Aí, sei lá, a gente fica muito revoltada, muito revoltada e nervosa." (Sujeito 06).

Embora todas as mulheres deste grupo tenham sido contaminadas pelo companheiro em relacionamento estável, apenas uma delas expressou revolta no momento do diagnóstico:

"No momento quis matar meu marido, porque eu sabia muito bem o que eu fiz, então eu sabia que não era eu. E sabia dos defeitos dele." (Sujeito 02).

Defeitos estes que incluíam o uso de drogas intravenosas e relacionamentos extraconjugais ocasionais. Ainda que o discurso do sujeito 02 reflita a negação do 
risco, revela também que o risco fez e faz parte da sua trajetória. Entretanto, não se dá conta disso e relata seu risco como algo alheio, externo, tão estranho que, quando demonstrado através do exame, provoca espanto e revolta.

Fica evidente aqui a condição de submissão da mulher nas relações de gênero, decorrentes das construções simbólicas da masculinidade, cujas representações se ancoram no gosto pela aventura e na liberdade sexual aberta ou velada; e da feminilidade, com representações ancoradas na maternidade, passividade e na fidelidade (Paulilo, 1999).

A revolta por ter sido contaminada pelo companheiro, faz com que se transporte para o outro lado, para o mundo do qual só o companheiro fazia parte:

"Quando eu descobri que tinha o HIV, eu não queria ela (a criança que gerava). Comecei a usar drogas, fumar, beber, sabe, extravagâncias, pensei até em me suicidar." (Sujeito 02).

Ela passa, ainda que temporariamente, a viver de acordo com as representações que fazia das pessoas que estariam vulneráveis ao HIV, ou seja, o usuário de drogas, o "farrista"(sic). Isto nos remete aos dizeres de Balandier (apud Paulilo, 1999), quando coloca que

"a solidão, a crise identitária, as dificuldades que enfrenta o indivíduo para se definir, para preservar sua autonomia, fazem com que ele se torne seu próprio produtor de significações das representações do mundo em que ele se encontra presente. Ele o constrói em certo sentido sob o impulso das circunstâncias, das necessidades imediatistas e também do acaso das influências recebidas” (p. 25-26).

O diagnóstico trouxe para o sujeito 02 , a perda de uma identidade construída socialmente. Ela não consegue estabelecer seu valor pessoal, de encontrar um significado para sua existência. Busca, então, nas drogas, na "extravagância" , uma 
forma de auto-referência, de procurar com os recursos de que dispõe, reconstruir a sua identidade.

Para os sujeitos 08 e 09, o momento do diagnóstico pode ser caracterizado como um mergulho no desespero:

"Na hora eu quebrei tudo, eu quase demoli o banheiro... eu caí em depressão, não comia, comecei a piorar, não comia nada. Aí o médico disse que eu não ia sair do hospital... nada mais é a mesma coisa". (sujeito 08).

"Me deram um comprimido primeiro. Quando vieram me contar, eu quis me jogar lá de cima. A moça que segurou em mim. É mentira, é mentira, é mentira... eu falei pra ele (o marido). Mas ele falou: é assim mesmo. Me deram um calmante. Chorei a noite inteirinha, quase matei os meus filhos porque não tive cabeça pra cuidar deles". (sujeito 09)

O diagnóstico soropositivo trouxe junto uma profunda ruptura, desordem, desorientação em suas vidas. O futuro, naquele momento deixou de existir, destruindo também o presente.

Na verdade, o momento do diagnóstico soropositivo para o HIV, não é apenas a descoberta de uma doença. As histórias pessoais narradas por estas mulheres nos levam a inferir que, para elas, foi um momento de perdas, ou seja, é a vivência por antecipação da doença significando a destruição dos seus vínculos sociais e afetivos, a exclusão, a solidão, a morte. Para algumas, é a perda de tudo, inclusive de si próprias.

\section{- Convivendo com a Soropositividade}

Depois do impacto sofrido pelo diagnóstico soropositivo para o HIV, 
depois da raiva e da depressão, vem a necessidade da reestruturação e manutenção da vida com seus vários papéis.

A estruturação da identidade feminina se faz acompanhar do conformismo, do ocultamento, do silêncio - que não significa a inexistência de discurso - que é passado através das gerações como um modelo legitimizado da mulher. A soropositividade rompe com o silêncio, revela segredos, levando ao confronto de situações que abalam o sistema de valores das mulheres em questão. Assim, assumir sua condição soropositiva significa ter várias perdas, inclusive da identidade construída durante toda a vida:

"Não é mais a mesma coisa, porque parece aquela coisa,
onde você vai sempre tem alguém que vai tocar nesse
assunto. Tem pessoas que você tem certeza que não sabem,
que você nunca viu, mas tem outras que parece que falam
porque tem medo de pegar e tão sempre lembrando a
gente." (Sujeito 08) É na relação interpessoal que o mundo de significados é partilhado. As atitudes de um são orientadas pelas atitudes do outro e, a partir daí, cada indivíduo é capaz de refletir sobre sua própria identidade.

"Ah! A gente evita muita coisa depois. Começa a ficar com um pouco de medo. A gente tem preconceito da gente mesmo. É o tal negócio, beijo não pega, mas com criança a gente tem medo, pelo menos eu tenho. Daí eu tenho um pouco de preconceito, então eu acho que mudou um pouco, mudou sim." (Sujeito 04)

A soropositividade passa a fazer parte de todos os momentos do seu cotidiano, provocando alterações na rotina e nos relacionamentos familiares e sociais.

"O tempo que eu tinha antes para ficar com os meus filhos, 
agora eu ando atrás de médico. Antes, pra mim, primeiro eram os filhos, minha casa, o meu serviço. Agora, se eu fizer isso, amanhã não vou estar lá para cuidar deles." (Sujeito 10)

No discurso do sujeito 10, pode-se observar uma identidade construída por determinantes sociais, historicamente edificados, que delegam à mulher o papel de esposa e mãe. Mesmo com a necessidade de criar uma nova identidade após o diagnóstico soropositivo para o HIV, incorporando o adoecimento e cuidado com a saúde, este cuidado se constitui em relação ao outro, ou seja, na manutenção de seu papel de cuidadora, mesmo quando é ela quem necessita de cuidados. Como afirmam Leal e Boff (1996), "basicamente o sujeito feminino se constitui em relação ao outro: ou se constrói como mãe, em um código de reciprocidade em relação aos filhos, ou se constrói como esposa, em uma dada hierarquia relacional com respeito ao companheiro” (p.131).

A vinculação de estereótipos físicos aos doentes de AIDS, como magreza ou deficiência física, ainda aparece no discurso destas mulheres.

“... os remédios que eu tomo, pode ser bobeira, mas é uma coisa que mexe comigo... os remédios... o meu corpo parece que tá ficando deformado, o meu corpo mudou, minha fisionomia. Mudou porque as pessoas falam pra mim. Eu não via, mas acabei enxergando de tanto as pessoas falarem." (Sujeito 03)

Em estudo sobre os fatores psicossociais que dificultam a adesão das mulheres portadoras do HIV aos cuidados de saúde, Tunala et al. (2000), ressaltam o quão estigmatizante pode ser os efeitos colaterais do coquetel (lipodistrofia), principalmente pelo fato destas mulheres acharem que os outros percebem sua condição soropositiva através da aparência física ou simplesmente pelos efeitos na 
auto-imagem.

A soropositividade traz consigo também a perda da capacidade para o trabalho e com isso, a estabilidade e credibilidade adquiridas perante a sociedade como um ser produtivo.

"Se não fosse esse vírus eu acho que tava sendo uma pessoa diferente do que eu sou. Eu não me acho capaz de fazer coisa alguma. Eu tenho vontade de fazer as coisas, mas eu acho que não me sinto, assim, capaz. Eu queria voltar a trabalhar, fazer alguma coisa, mas eu não me acho capaz, parece que não tenho capacidade. Eu acho que tenho medo de ficar doente, de não conseguir.” (Sujeito 03)

O trabalho na sociedade capitalista, de acordo com Laurell (1981), fez emergir novos papéis e valores sociais: provedor, utilidade, positividade, capacidade, força, eficiência, etc. O significado do trabalho está, desta forma, associado ao ato de viver, uma vez que proporciona as condições materiais e morais de sobrevivência própria e da família. Assim, a incapacidade trazida pelo adoecimento significa não corresponder às suas expectativas, as da família e as da sociedade, concorrendo para a frustração e interrupção de um projeto de vida pessoal, familiar e profissional cujos padrões tem sustentação social.

O trabalho, segundo este mesmo autor, encontra-se vinculado a vários atributos e funções morais. É por meio dele que o indivíduo atribui significado e sentido à própria existência. Tendo o trabalho um sentido tão amplo e estruturante na vida das pessoas, qualquer limitação que impeça de exercer uma atividade produtiva, provoca alterações profundas em sua vida, tornando o indivíduo doente mais sujeitado e sem direitos.

Ao estudar a saúde do proletariado, Dejours (1986), observou que a doença 
era causa de vergonha, sendo associada à vagabundagem. Estar doente significava, para os homens, interromper o trabalho profissional e para as mulheres, o doméstico, sendo portanto irresponsável frente ao cumprimento de seus papéis sociais.

Em estudo realizado com mulheres faveladas, Sawaia (1994), demonstrou que só a revelação da pobreza e seus nexos não altera uma situação real. Segundo a autora, o pensamento não é autônomo, descolado do empírico. É no seu encadeamento com as condições materiais de existência que se vislumbra a possibilidade de saltos qualitativos, em direção à consciência crítica. Sem avançar a ação, gera-se uma forma de alienação que separa a consciência da atividade e o pensar do fazer e do sentir. Mas não basta a ação avançar para que, automaticamente, a consciência se transforme. A ação tem de ser refletida e sentida para ser incorporada à subjetividade.

Tradicionalmente, o papel feminino é circunscrito ao domínio do privado, definindo-se como suas responsabilidades centrais ser esposa, mãe e dona de casa, como é o caso das mulheres deste estudo. Mas em nossa sociedade, o trabalho doméstico, a educação dos filhos e a administração da casa são percebidos como não produtivos, o que não contribui para a construção de auto-estima positiva para a mulher.

Apesar do reconhecimento que uma atividade remunerada pode significar mais autonomia e poder de decisão para a mulher, o trabalho externo, remunerado, portanto produtivo, aparece como algo secundário à sua função de doméstica, sendo possível, desde que não interfira em suas funções no lar.

A AIDS foi incorporada à vida destas mulheres afetando-as profundamente. 
A convivência com o vírus traz ao cotidiano de sua vida categorias polares, contraditórias. Ao lado dos riscos, da incerteza, da perplexidade, convivem com a esperança, a fé, a confiança.

A resposta dada pelo sujeito 02 , quando questionada sobre o que é viver sendo soropositiva ilustra o conflito existente em sua vida.

"As pessoas podem te perguntar várias vezes, eu não vou saber te dizer o que é, tá sempre confuso. Te explicam algumas coisas, algumas coisas ficam claras, outras ficam confusas. Então, sei lá, tem hora que não dá para entender" (sujeito 02).

Ao analisar as respostas deste grupo de mulheres no conjunto de suas histórias de vida, pode-se observar que aquelas que tiveram uma vida mais difícil desde a infância - desestruturação familiar, caso de alcoolismo paterno, carências econômicas e afetiva e até mesmo violência - após a crise vivida no momento do diagnóstico, apresentam melhor adaptação à situação. Sem dúvida, esta diferença de reação está associada com a capacidade desenvolvida ao longo da vida para lidar e conviver com situações adversas. Neste grupo estão inseridos os discursos dos sujeitos 03, 04, 05, 07 e 10:

"No começo é difícil da gente aceitar, mas daí a gente vai aprendendo a conviver. Ainda é difícil. Bem que eu esteja bem de saúde, mas sem enganos que ela mexe com a gente. Mas é coisa que a gente vai levando" (Sujeito 03).

"Eu acho que, já que estou, não posso fazer mais nada. Eu procuro levar uma vida normal porque não adianta a gente desesperar. Se fosse resolver algum problema, né? É o que eu penso" (Sujeito 07).

"Só muda o cuidado com a saúde, que deve mudar" (Sujeito $10)$. 
"Eu pus na cabeça que morrer todo mundo vai, então eu não penso muito nisso não. Eu só acho que é uma doença como uma gripe. Se tiver que morrer disso, vai morrer, senão vai morrer de outra coisa. Eu penso assim" (Sujeito 04).

"Logo no começo eu fique bem chocada, mas depois eu fui indo, falei: cada um tem o que passar. Se esse foi o meu destino..." (Sujeito 05).

Se por um lado este tipo de atitude significa uma alternativa real para o enfrentamento da doença no seu cotidiano, por outro, este discurso reflete a fala do oprimido. Pressão esta que faz com que incorpore a doença como parte de seu “destino" de submissão. Estas estratégias de passividade e submissão utilizadas por estas mulheres como estratégia de sobrevivência, atuam como um obstáculo para o questionamento, que seria o único meio capaz de reverter esta ideologia que naturaliza e impede a transformação.

A narrativa de suas histórias de vida nos permite observar que estas mulheres sempre sofreram, desde a infância, o que Sawaia (1994) denomina de falta de amparo externo real (falta de controle absoluto sobre o que ocorre) e, também, a falta de um amparo subjetivo (falta de recursos emocionais para agir). Esta falta de amparo fez com que adquirissem, nas relações sociais do cotidiano, um sentimento de impotência diante dos objetivos desejados e a consciência de que nada podem fazer para melhorar seu estado, sob o risco de mais sofrimento. Esta falta de poder sobre si e sobre os acontecimentos é caracterizado por Sawaia pela falta de recursos emocionais, ou seja, um estado letárgico de apatia que ocupa o lugar das emoções até neutralizá-las, condensando os sentimentos de indignidade, inutilidade e desqualificação. 
$\mathrm{Na}$ busca de um sentido que justifique o acontecido, na necessidade de encontrar um responsável, na impossibilidade de questionar sua condição de submissão, o sujeito 05 questiona a ciência médica.

"Eu fico meio perdida... Eu fico perguntando: como é que pode acontecer uma coisa dessas e até agora não ter cura?” (Sujeito 05)

E questionando a eficiência da medicina, confronta também as estruturas sociais como um sistema organizado na base da opressão, da exploração e da exclusão social e econômica.

Nas palavras de Minayo,

"saúdeldoença constituem metáforas privilegiadas para explicar a sociedade: engendram atitudes, comportamentos e revelam concepção de mundo. Através da experiência deste fenômeno, as pessoas falam de si, do que as rodeia, de suas condições de vida, do que as oprime, ameaça e amedronta. Expressam também suas opiniões sobre as instituições e sobre a organização social em seus substratos econômico-político e cultural" (1998, p.193).

O sentido atribuído pelo sujeito 09 à soropositividade é o da destruição, expressando em seu discurso a total inexistência de vínculos sociais, a auto-exclusão em decorrência da discriminação. Sua vida é uma sucessão de perdas que a tiraram a capacidade de enfrentamento. Para fugir da carência extrema aos 12 anos vai morar com um vizinho bem mais velho que, alcoólatra, lhe infringe todo tipo de violência, inclusive sexual. Depois de um ano foge, indo morar nas ruas, sobrevivendo da mendicância. Aos 14 anos conhece um homem, também bem mais velho, que se apaixona por ela e com quem se casa. Com ele passa a ter uma situação econômica estável, a segurança de um lar. Conforme suas palavras: 
marido.” (Sujeito 09)

Passados sete anos, no parto dos filhos gêmeos, recebe o diagnóstico soropositivo, ao que o marido confirmou já ter conhecimento. Nestes cinco anos que decorreram até então, desfez o casamento, sofreu discriminação da família, perdeu a casa, colocou os filhos em uma Instituição para crianças soropositivas e não os viu mais, perdeu o emprego. Perambulando pelas ruas, foi encaminhada por um policial para uma casa de apoio, onde se encontra.

Na concepção de Paulilo (1999), ela está imobilizada, recusando-se a interagir e, assim procedendo, impede que outras referências, novos significados a auxiliem a elaborar seus medos, a desmontar seus parâmetros e a construir outros. Já perdeu tanta coisa, não pode arriscar-se a perder mais nada. Passa a viver na clandestinidade, à margem do mundo, impondo uma ruptura do social. Vive na ausência, conforme Le Breton (apud Paulilo, 1999), onde o indivíduo não consegue estabelecer seu valor pessoal ou encontrar um sentido para sua vida, prevalecendo uma reação de abandono, desistência, diluição, de fragmentação do eu. É um vagar sem rumo, sem destino, de onde emana uma indiferença ao ato de existir. No entanto, o fato de freqüentar as consultas médicas e, mais ainda, aceitar falar de si nesta entrevista, demonstra que esta ausência não se configura em busca ativa da morte, e sim em uma falta de atração pela vida.

Os depoimentos aqui descritos não deixam dúvida de que a vivência da soropositividade ao HIV é bastante confusa. Este período de latência, onde se é portador de um vírus, mas não da doença, ocasiona desordens, incertezas referente a um mal que é real e irreal ao mesmo tempo. Esse fator faz do soropositivo uma 
categoria especial de indivíduo, que nem é saudável, nem doente.

\section{- Estigma, Discriminação e Preconceito: a marca da diferença}

A palavra estigma tem origem na Grécia para denominar os sinais físicos usados para demarcar o indivíduo que era escravo, criminoso ou traidor, cujo contato deveria ser evitado pela população dita normal. Assim, o termo passou a ser usado para referir-se a um atributo depreciativo, dando origem à discriminação, que reduzem a chance de convívio social (Goffman, 1988).

A AIDS, de acordo com Parker, citado por Paiva (2000),

"trouxe à tona, de maneira nova e assustadora, os fantasmas construídos no imaginário social sobre a sexualidade $e$ a morte, sobre o desfiguramento e o enfraquecimento físico, sobre a vulnerabilidade $e$ o risco visto na cara do outro. Mais do que qualquer outra doença na era moderna, a AIDS revelou a nossa relação ainda não resolvida com a diferença e os diferentes, relembrando-nos da longa história que sempre vinculou o medo da diferença com a discriminação, estigma $e$ o preconceito. (...) a AIDS demonstrou mais uma vez, com nitidez especial, a nossa capacidade de negação coletiva quando confrontados com o profundo sofrimento de setores já marginalizados em um sistema social organizado na base da opressão, da exploração e da exclusão social $e$ econômica” (p.13).

Estes fatores geram associações simbólicas com a doença que atinge profundamente os indivíduos, influenciando-os na percepção de sua doença e no comportamento de outras pessoas frente a ela. Como resultado, observam-se sentimentos de ansiedade motivada pelo medo da rejeição social.

Para o grupo de mulheres estudado, o medo se faz presente no cotidiano. Entretanto é mais o medo pelo outro, ou seja de ser causa de sofrimento para os filhos ou família, conforme pode ser observado nos relatos a seguir. 
“...de saber que o neném pode nascer com isso. Ver mais tarde que a cura não chegou ainda. Deixar meus filhos pros outros criar". (Sujeito 01)

"Eu sempre tive o desejo de ter filhos, aí quando tenho minhas meninas, eu não tenho a chance de criar..." (Sujeito 02).

“... o que mais me angustia são os meus filhos. Que eu tenho medo deles não negativar, que aconteçam essas coisas com eles" (Sujeito 06).

“... mas de vez em quando vem, bate a tristeza. Pega na angústia, tristeza, medo. Não medo de morrer, isso aí eu não tenho. Mas é um medo assim, de deixar meus filhos pequenos ainda." (Sujeito 05)

Observa-se que, maior que a preocupação com a sua situação de soropositiva para o HIV, é vir a deixar seus filhos sem amparo.

Cuidar é uma atribuição feminina. A atividade de cuidar dos filhos é representada no imaginário social como uma função natural da mulher. Uma explicação possível, segundo Unbehaun Ridenti (1998), seria a de que a maternidade, pela ligação com o corpo, é um elemento muito forte em nossa cultura. As responsabilidades parentais seriam assim definidas considerando como principal referencia a mãe, a partir do principio biológico de que é no corpo dela que o bebê é concebido.

Por outro lado, não se pode desconsiderar a tradição patriarcal, reforçada pela religião, que ainda hoje influi na manutenção das mulheres no espaço doméstico, a quem é destinado sobretudo às atividades reprodutivas e os cuidados com os filhos, enquanto aos homens cabe o espaço público e o papel de provedor, principalmente nas classes sociais menos favorecidas. 
Outro aspecto levantado como gerador de medo e ansiedade é a dificuldade em revelar o diagnóstico aos filhos nascidos antes da contaminação.

"O medo de deixar meus filhos, chegar a eles e contar e eles ficarem diferentes. E também dos outros ficarem sabendo. Não conto pra ninguém que é para eles não serem enjeitados na escola pensando que eles tem. Se a mãe tem, o filho também tem, né? Então, eu já não conto por causa disso, porque eles não têm, mas os outros pensam que têm. Aí fica o medo e eu tô evitando falar." (Sujeito 05)

Um estudo realizado por Oliveira (2000) sobre o surgimento do HIV no contexto familiar a partir do diagnóstico do pai ou da mãe e as conseqüências para seus filhos, demonstrou que $40 \%$ destes filhos enfrentam preconceito devido à doença de um ou ambos os pais. Muitas vezes este preconceito surgiu dentro da própria família, paterna $(13,1 \%)$ e materna $(23,7 \%)$, mas também vem da escola $(15,5 \%)$, dos amigos e colegas $(10,5 \%)$, dos vizinhos $(18,5 \%)$ e do bairro $(13,1 \%)$.

Portanto, os receios do sujeito 05 não são infundados. Torna-se necessário, portanto, estudos e planejamento de intervenções adequadas, para que se possam minimizar os efeitos conflitantes da soropositividade dos pais para os filhos soronegativos, visto ser este um segredo impossível de ser mantido indefinidamente.

O sujeito 05 também expressa receio em falar com sua família sobre sua situação soropositiva, não pelo medo da rejeição, mas por não querer que sofram por sua causa.

“...medo de falar pra eles (família). Não que eles tenham preconceito, que eles não tem, só que eles são muito apegados a mim, eu sou a caçula, qualquer coisinha comigo e a preocupação deles já é demais”. (Sujeito 05)

Apenas o sujeito 03 demonstrou em seu discurso receios em relação a si 
mesmo.

"Eu tenho medo de ficar doente. Voltar a ficar doente igual ao que fiquei. E do preconceito. Acaba enrascando a pessoa." (Sujeito 03)

O preconceito enquanto situação vivenciada, se apresentou para $50 \%$ do grupo estudado, sendo, na maioria, dos casos proveniente da própria família, sendo também citado a comunidade e o local de trabalho.

"Minha mãe, ela tem muito preconceito. Até hoje ela não foi lá em casa. Ela ficou diferente comigo, assim, faltou pouco pra ela falar assim: você vai embora!" (Sujeito 03)

"Ás vezes eu chegava na casa dos meus irmãos, minhas cunhadas e eles falavam assim: ah! Vai embora daqui!" (Sujeito 09)

"Quando o J. (primeiro marido) morreu, os parentes dele achavam que ele tinha pegado alguma coisa de mim, só o que ninguém sabia é que se alguém tinha pegado alguma coisa, fui eu, porque eu nunca tinha tido ninguém. Aí começou aquele negócio, porque todo mundo ficou sabendo, os irmãos dele começaram a me irritar, não conversavam comigo, não chegavam mais perto de mim, as irmãs dele também. Eu lembro que se eu bebia água, jogavam o copo fora. Até que eu vim embora. O resto do pessoal, ninguém sabe, então não tem como ter medo." (Sujeito 04)

"Tinha uma vizinha que eu fazia unha na casa dela. Aí uma cunhada dela foi na outra vizinha que também fazia unha lá e perguntou se ela não tinha medo de pegar porque eu fazia unha lá. Aí ela veio me contar. Eu não liguei muito, não, mas fique nervosa. Aí fui lá e xinguei ela, falei que não tinha nada que ver com a minha vida, que se eu tenho, o problema é meu. Aí ela falou: Então traz um exame aqui pra eu ver. Ah! Gente ignorante, quase bati nela. Fiquei tão nervosa”. (Sujeito 06)

"Nos dois serviços que eu arrumei, ligaram pra lá, falaram pra minha patroa que eu tinha... eu perdi o emprego". 
(Sujeito 01).

Ainda que exista um grande esforço do meio científico para dar ao conceito de transmissão da AIDS um sentido mais racional através da elucidação dos seus meios, não conseguiu substituir o conjunto das representações e imagens simbólicas provenientes de antigas epidemias. São representações que surgem de sensações vividas, encontrando, posteriormente, uma justificativa fornecida pela razão. Além disso, as significações culturais ligadas á noção de contágio produzido pelo discurso médico-científico que associou a ocorrência da doença ao sentido do tato (contato) e olfato (pelo ar), permanecem nas representações que os indivíduos fazem do adoecimento (Czeresnia, 1995). Estas representações carregam a soropositividade de estigmas, atualizando vivências de medo, exasperação, negação e rejeição ao outro, e que estão presentes no discurso destas mulheres. Como conseqüência do preconceito sofrido, resulta o isolamento:

"Agora não vou mais na casa de ninguém, ninguém vai na minha casa. Sair de casa dá problema." (Sujeito 06)

Para driblar o estigma e o preconceito que, apesar de não ter vivenciado, sabe existir, o sujeito 10 prefere o silêncio:

"Eu acho que nunca muda isso aí. Desde o primeiro caso até hoje é a mesma coisa, todo mundo fala, mas todo mundo sai longe. Quando chega na família é pior. Não sofri preconceito porque ninguém sabe." (Sujeito 10)

Não revelar sua condição de portadora é uma saída diante dos problemas emergentes da situação da soropositividade que, concordando com Tunala et al. (2000), não necessariamente configura uma "defesa neurótica que necessita de tratamento" (p. 03). 
Entretanto, ainda concordando com estes autores, este silêncio em relação à infecção, além de impedir o seu compartilhamento com outras pessoas que poderiam ajudar no enfrentamento á doença, prejudicam na adesão ao tratamento pela dificuldade de ingerir os medicamentos quando estão na presença de outros. Todos estes aspectos - manter o sigilo, não ter com quem compartilhar, esconder o medicamento - constituem-se em mais fontes estressoras no seu cotidiano.

\section{- Rede Social}

Em decorrência do medo pela discriminação, a rede de apoio, ou seja, àquelas pessoas a quem estas mulheres contaram sobre sua soropositividade, não é extensa. O companheiro atual, nem sempre o responsável pela transmissão, é o mais citado por ser a pessoa que tem o direito de saber. As pessoas da família que estão mais próximas também formam esta rede de conhecimento sobre a soropositividade. No entanto, dois aspectos chamam atenção neste grupo de mulheres: o pacto de silêncio estabelecido entre os que sabem e o fato da família do companheiro, ao invés da própria família, ter acesso ao diagnóstico.

O silêncio se faz presente tanto entre as pessoas que estas mulheres buscaram para contar sobre o diagnóstico, mas que não falam sobre o assunto, como para quem ficou sabendo através de outros meios e que fingem não saber. Este pacto faz com que estas pessoas não configurem uma rede de apoio, ficando apenas na comunicação do fato. Falar sobre o HIV/AIDS é trazer a doença para o cotidiano, é ter que enfrentar e buscar respostas e, principalmente, revela sua proximidade, torna visível a vulnerabilidade que ronda a todos: 
"Só eu e ele (companheiro). Pra minha família eu não conto. Vou achar que eles estão com nojo, tão me olhando com dó, com pena (...) Por isso não vou contar tão cedo. Só se eu tiver ruim mesmo, precisando mesmo da minha mãe, aí sim eu contaria. Mas fora isso eu não pretendo contar. Eu não tenho que contar, não. A única pessoa que eu tinha que contar, eu já contei. E é com ele que eu desabafo. Só ele tá sabendo, tá bom, por enquanto tá bom. O meu irmão, uma vez brigando comigo, disse: "Ah! Você vai morrer logo, você tem AIDS". Mas aquilo me machucou tanto. Aí minha mãe entrou e falou: "Vira essa boca pra lá". Minha mãe eu acho que desconfia, ela sabe do meu primeiro marido.Só que ela não fala, não discrimina em nada, ela sempre faz o possível para estar comigo.” (Sujeito 01)

"Só os médicos, ele (companheiro), e só. Na minha família, não. Eu não quero que ninguém fique sabendo porque eu tenho uma convivência boa, mas à distância. Os meus filhos são muito queridos por eles e isso me deixa bastante feliz. Mas eu te garanto que, se amanhã ou depois, eles souberem, vão se afastar dos meus filhos. Eu não quero que isso aconteça.(...) Eu não me sinto com vontade de falar. Eu acho que ninguém mais tem o direito de saber, a não ser o meu marido, que é o maior interessado." (Sujeito 10)

Algumas pessoas da família são escolhidas pelos sujeitos 02, 03, 06 e 07, para compartilhar do conhecimento do diagnóstico:

"Eu, ele, minhas irmãs, um pouco das irmãs dele, nem todos e só. $O$ resto a gente ignora falar porque, como o irmão dele que nem instrução tem, não ia entender, né." (Sujeito 02)

"Meus familiares, minha sogra, minha cunhada, minha irmã. Fiquei mais ou menos sozinha. A minha sogra me deu muita força, ela tem uma cabeça diferente de todo mundo." (Sujeito 03)

"Só a minha família de dentro de casa, que nem a minha sogra, que sabe. A família dele toda sabe." (Sujeito 07)

"Eu contei pra minha mãe, pra mãe dele, pro pai dele. E eu que contei. Ele não contou. Eu tive que chegar e falar. Só 
que nisso mais gente ficou sabendo. Tem gente que eu chego e falo numa boa porque eu sei que essa pessoa não vai ficar criticando. Agora, tem gente que fica falando e criticando. Eu não gosto de críticas”. (Sujeito 06)

Pelos relatos podemos observar que, na maioria dos casos, a família do companheiro tem conhecimento do diagnóstico, enquanto a família das mulheres nem sempre são conhecedoras, ou ainda, apenas alguns membros tem conhecimento. A explicação para isso talvez esteja no fato de que a contaminação destas mulheres se deu pelo contato com o parceiro, o que as torna vítimas, portanto não estão sujeitas à criticas por parte da família dele. Por outro lado, em relação a família delas, a situação pode ser vista de forma diferente, afinal foram elas a escolherem os parceiros, o que as torna sujeitas à questionamentos e críticas. Elas querem que suas famílias entendam o que aconteceu sem as condenarem, conforme relata o sujeito 05:

"A família dele que sabe. A minha não tá sabendo, só um irmão que sabe. É o mais novo dos homens, ele sabe. Ele é o que eu converso mais, é o mais chegado. Se eu comento uma coisa dessas pros outros, eles vão entender, mas logo que eu falar, eles vão ter uma reação.(...) Se um dia eu falar pra minha família, eu quero explicar pra minha família. Eu quero contar pra minha família, eu não quero esparramar pros meus amigos, pra depois não saírem falando, esparramando pros outros e, quando você pensar que não, você ta sendo rejeitada. Então, é isso que eu fico pensando. Melhor ficar quieta. Não tem que sair falando: ah! To com isso, to com aquilo." (Sujeito 05)

Conforme podemos constatar pelas histórias de vida deste grupo de mulheres, o modo como as famílias se adaptam à doença é um reflexo do seu relacionamento íntimo, de suas histórias e do contexto sócio-cultural em que estão inseridas. Quando a estrutura familiar apresenta um relacionamento satisfatório, o nível de receptividade e de compreensão se dá mais facilmente, trazendo ao membro 
que se encontra fragilizado diante da doença, um fortalecimento através das relações de ajuda e afeto.

O preconceito existente em torno da doença faz com que os portadores se tornem carregados de culpa diante do que não podem reverter - culpa que a família, amigos e a sociedade reforçam com cobranças, discriminação, isolamento e omissão. A soropositividade e a discriminação resultante induzem estas mulheres a um mundo de meias verdades, evitamentos e disfarces. A revelação de sua condição de positiva para o HIV poderá ser a sua condenação ao que tão acertadamente Betinho denominou de morte civil. Assim, na tentativa de proteger-se e proteger aos que preza, o medo as leva muito mais a se esconderem do que a se revelarem.

De acordo com Lazarus e Folkman (1994), os eventos estressores, a princípio são vistos pelo indivíduo como uma ameaça, transformando-se a seguir em desafio. A AIDS é uma doença que provoca experiências de ruptura na etapa inicial, mas que também desafia a pessoa a engajar-se em uma contínua avaliação de sua vida. Este desafio é ainda maior para as mulheres deste estudo que, além da própria contaminação, têm a necessidade de manter seus vários papéis na estrutura familiar esposa, mãe, filha, dona de casa, dentre outros. Assim, o enfrentamento da doença pelas mulheres é "permeada por uma mescla de sentimentos híbridos, conflitivos e contraditórios" (Gir, 1998), onde ao mesmo tempo em que vivem momentos de esperança, de superação de problemas, vêem um amanhã incerto.

Os determinantes das formas de enfrentamento à doença são preditos por fatores de diferenças individuais e experiências de vida (Kelly, 1998). Na tentativa de reconstruir suas vidas, agora convivendo com a soropositividade, estas mulheres buscaram força principalmente nos filhos (40\%), na religião (30\%), em si mesmo 
(20\%) e na normalização da vida diária (10\%).

Muitos depoimentos evidenciam que a coragem para a superação das incertezas e limitações trazidas pela soropositividade é dada pelos filhos:

“...acho que é isso que me dá força pra viver, os meus filhos. Pensar que eles podem não ter uma mãe...” (Sujeito 02)

"É saber que meus filhos não tem ninguém a não ser eu. Então, por isso que você tem que levar a vida pra frente, esquecer, tentar viver..." (Sujeito 10)

"Ah! Me aproximar mais dos meus filhos, dar mais amor a eles, pensando mais neles, pensando em mim mesmo..." (Sujeito 05)

Assim como no momento do diagnóstico os filhos trouxeram a vontade para superação da crise, para muitas mulheres são também os filhos que servem como maior motivação para a vida.

A religião também surge como apoio, representando uma importante rede de suporte emocional. A fé na cura se assenta na crença num poder superior, que lhes dá esperança e crédito:

"Eu me pego com Deus, eu rezo, entrego a minha vida, faço minhas orações, peço a Jesus Cristo ajuda, pra me dar força. Aí cada dia pra mim é um dia novo e eu vou pedindo e agradecendo. Em certas fases da minha vida parece até que foi um milagre, então eu considero muito, Deus me ouve muito." (Sujeito 02)

"Eu acho que, se você tem uma religião, se você acredita, eu acho que ajuda muito à pessoa assim como eu. Eu rezo muito. Ajuda muito e é muito importante." (Sujeito 03)

"A gente não pode procurar Deus ou a religião só depois 
que tem alguma coisa. Pra mim continua a mesma coisa. Deus está me ajudando muito. Com muita oração, muita fé, muita leitura e aprendendo mais." (Sujeito 05)

"Sou católica. Eu acho que a gente tem que ter muita fé em Deus, acreditar que Deus existe. Eu vou direto, todos os domingos, na Igreja." (Sujeito 07)

“A religião, pra mim, não tem importância nenhuma, o que importa pra mim é ir na Igreja escutar a palavra de Deus, porque é a palavra de Deus que conforta muito a gente. É ela que dá força, não é a Igreja. Não é a religião que vai salvar ninguém por causa da Igreja. O que dá força mesmo é a palavra de Deus”. (Sujeito 06)

Para Pinezi-Barbosa (1999) a religião, além de atuar como fonte de orientação para que o indivíduo se reconcilie com Deus por meio da conversão, é também um espaço em que socialmente são construídas regras de conduta e padrões de vida compatíveis com os preceitos divinos interpretados, em alguns casos seguidos e em outros adaptados ou desobedecidos.

Para os Sujeitos 09 e 01 o diagnóstico foi o ponto de busca pela religião:

"Eu não era de Igreja. Aí comecei a ir na Igreja, pedir pra Deus me dar força e fui enfrentando aos poucos. Eu fui em todas Igrejas em R. P. Mas a que mais fui foi na Universal. Mas agora tô indo na "Deus é Amor". Lá eu me sinto bem." (Sujeito 09)

"Desde que eu fiquei sabendo que eu tinha HIV, que eu fui na Igreja. Aí na palavra deu que a minha vida tava na mão de Deus, que só ele podia me dar a salvação. Mudou muito a minha vida. Eu pensava muita besteira antes de ir na Igreja, eu pensava muita besteira. Eu falava assim: eu vou me matar. Hoje eu falo assim: Vão pra Igreja porque Ele pode salvar." (Sujeito 01)

Muitos estudos abordam as diferentes estratégias pelas quais as religiões reinterpretam a experiência da doença e modificam a maneira pela qual o doente e o 
meio social definem o problema. Para Lévi-Strauss (1967), as teorias religiosas curam ao impor ordem sobre a experiência caótica do doente e da família.

Gertz (1989) esclarece que a religião

"é um sistema de símbolos que atua para estabelecer poderosas, penetrantes e duradouras disposições e motivações nos homens, através das formulações e de conceitos de ordem de existência geral, e vestindo estas concepções com tal aura de fatalidade que as disposições $e$ motivações parecem singularmente realistas (1989: 104-105).

Segundo Reed (apud Gir, 1998), as religiões são criadas como uma estrutura para um sistema de crenças, valores, códigos de condutas e rituais e apresentam os componentes de fé, ou crença, esperança e amor.

Os depoimentos mostram que a maioria das mulheres se beneficiam de sua crença religiosa, visto se tornarem fonte de esperança, uma forma de enfrentamento e alívio para o sofrimento, medo e angústia. Durkhein (apud Lima Ferreira, 1978) considera que o indivíduo que tem crenças religiosas sente em si mais força, seja para suportar as dificuldades da existência, seja para vencê-las, pois está como que elevado acima da sua condição humana. Assim, concordamos que o indivíduo soropositivo encontra na crença religiosa um grande auxílio para suportar as privações e angústias impostas pela doença.

A história de vida de algumas mulheres, que pode ser vista como uma história de superações em decorrência das inúmeras situações difíceis que fizeram parte de sua existência, as tornam fortes para que encontrem recursos em si mesmas para, mais uma vez, reestruturarem suas vidas:

"Eu sou uma pessoa que fui criada sem pai, trabalhei a minha vida toda, então, eu acho que a gente tem que arrumar força de qualquer maneira pra sobreviver. Não 
adianta desesperar. Quem me dá força sou eu mesma." (Sujeito 07)

“...eu sozinha. Porque se for esperar pela ajuda de alguém... Eu sozinha mesmo. Cuido das coisas sozinha.” (Sujeito 04)

Outro modo de enfrentamento citado foi a normalização, ou seja, tornar as coisas o mais normal possível, sem procurar informações ou situações que tornem a soropositividade presente no seu cotidiano. Suas energias são despendidas em fatores de resolução imediata do seu dia a dia, e estes ocupam todos os seus pensamentos, relegando a soropositividade para segundo plano.

"Eu tenho o problema, mas desconheço certas coisas que eu não entendo. Tem coisa que eu procuro entender e tem coisa que eu deixo um pouco de lado porque é meio assustador. Se você ignorar ela vai passar um pouco. Dor de dente é assim, dor nos pés é a mesma coisa. Então, eu procuro entender na medida do possível o que é mais importante." (Sujeito 02)

"Eu converso, saio, vou conversar com a minha mãe, vou na casa das minhas primas, vejo minhas sobrinharadas... com isso eu me distraio muito, já não me faz pensar muito nisso." (Sujeito 01)

Estas representações revelam as dificuldades de lidar com o presente e planejar um futuro repleto de limitações, exigindo que as identidades sejam reestruturadas sob novas bases.

A construção de uma nova identidade após o adoecimento e o retorno à normalidade - que não é a saúde - constitui-se num processo dinâmico e complexo que consiste em assimilar e produzir, de forma ativa, conhecimentos e formas de ação. Este processo promove uma série de mudanças, uma vez que as pessoas 
reagem de forma particularizada diante da nova realidade imposta. Alguns reagem de maneira positiva, criando formas de sentir e agir adaptadas à nova situação. Outros reagem negativamente, sentindo-se inseguros e incapazes de agir, pois não vêem um sentido para sua vida. Este aspecto torna-se saliente quando falam sobre o futuro.

É uma vida limitada em termos de possibilidades futuras, entretanto, mesmo diante de um mal incurável, o individuo faz planos para o futuro. Neste aspecto é importante observar que, mesmo quando afirmam não existir planos nem futuro, terminam por verbalizar a existência do desejo de continuidade. São respostas contraditórias, mas compreensíveis se consideradas as dificuldades de viver cotidianamente a promessa do futuro e a falta dele. Estes aspectos podem ser observados quando o sujeito 09, apesar de começar seu relato sem nenhuma perspectiva além da morte, encerra encontrando uma saída para que lhe possibilitaria continuar vivendo.

"O único plano que eu tenho é a morte. Todo dia é aquele sofrimento. Você vem aqui, o médico fala uma coisa, fala outra, prá que? Eu fiquei internada aqui. Nem falei nada pra minha família, sei que ninguém vai me ajudar mesmo. Fico aqui, fico ali, agora to lá no CETREM. Não sei o que vai virar. Quero ver se fico o mais longe daqui, tenho vontade de ir pra outra cidade. Acho que morando num lugar maior, um lugar que ninguém me conheça, começaria tudo outra vez". (Sujeito 09)

Ela coloca sua vida em um compasso de espera pela morte. No entanto, não se pode confundir a falta de esperança em desejo de morte. Em meio a tantas incertezas, limitações, isolamento e angústia, a morte é a única certeza que ela tem. Embora sinta-se impotente e incapaz diante da vida, quer continuar vivendo, ainda que clandestina em uma outra cidade. 
Para estas mulheres o futuro não é distante, os planos se fazem mais no presente.E mais uma vez, também seu futuro se faz em virtude da preocupação com os filhos. Na verdade, é com o futuro dos filhos que se preocupam, não com o seu. São estes filhos fontes de medo e de angústia, mas também a ancoragem do seu enfrentamento e força para manter-se viva. O cuidado com a saúde está, assim, vinculada a necessidade de manter-se bem para poder cuidar dos seus filhos, conforme os relatos dos sujeitos abaixo:

"Eu não faço planos. Eu só quero ter saúde e cuidar dos meus filhos. Criar meus filhos. Quero viver, ao menos até eu morrer independente de alguém ter que cuidar deles. Isso já é bastante para mim.” (Sujeito 10)

"Ainda não fiz planos, não. A minha vida ta meio descontrolada. Depois que ela nascer vou dar uma equilibrada na minha vida. (...) Vou me cuidar mais até poder deixar meus filhos, pelo menos minha filha mais velha, mais grande, pra cuidar dos irmãos pequenos". (Sujeito 05)

"Eu to tentando comprar um terreninho para construir uma casinha pra deixar pros meus filhos. Meu plano é esse. Vou deixar eles pras minhas irmãs, pra cuidar deles quando eu faltar, porque se eu faltar um dia, ele (o pai) não vai chegar muito longe, né? Vou procurar ver se eu consigo chegar até pelo menos 15 anos delas. Eu chegando nos 15, 16 anos delas já ta bom, porque já estão grandinhas. Já sabem se querem casar, namorar, o que fazer. Vamos ver se Deus ajuda nessa parte." (Sujeito 02)

"Ah! Tenho planos pra agora. Eu arrumei esse emprego, tava meio preocupada, mas parece que vai dar certo. Eu tenho planos de poder fazer tudo para ajudar minhas crianças, tenho medo deles sofrerem. Ah! Tanta coisa, tenho vontade de fazer tanta coisa. Se for começar a falar, vou ficar uma semana." (Sujeito 04)

“Meu plano é trabalhar, cuidar dos meus filhos, dar muito 
amor e carinho enquanto eu puder. É isso que eu quero pra eles. Eles são as coisas mais importantes que eu tenho na minha vida agora. E espero que a cura chegue um dia. $E$ difícil, né? Mas tem que... por que não, né?” (Sujeito 01)

\section{- Naturalizando a AIDS...}

A interpretação da doença tem uma dimensão temporal, não apenas porque a doença em si muda no decorrer do tempo, mas também porque a sua compreensão é continuamente confrontada por diferentes diagnósticos e situações construídos pela família, amigos, vizinhos, médicos. Assim, o conhecimento e o sentido dado à AIDS está continuamente sendo reformulado e reconstruído em decorrência dos processos interativos.

Esta temporalidade fica evidente nos discursos das mulheres entrevistadas. Entre aquelas com maior tempo de conhecimento do diagnóstico, a definição dada à AIDS enquanto doença é banalizada, naturalizada ou negada. Para o sujeito 01, diagnosticada soropositiva para o HIV há 5 anos, a Aids tornou-se normal com o passar do tempo, semelhante a tantas outras doenças:

"A AIDS é uma doença normal. Existem doenças piores que o HIV, assim como o câncer. HIV tem tratamento. Eu espero que ainda tenha cura, que a cura ainda venha. Por isso não me desespero. Nunca fiquei doente, é muito difícil ficar doente. Sou uma pessoa normal." (Sujeito 01)

Esse discurso é confirmado pelo sujeito 04, cujo diagnóstico foi dado há 9 anos.

"Eu penso que a AIDS é uma doença como outra qualquer." (Sujeito 04)

A morte que antes parecia tão imediata, agora parece ter sido superada, 
passando a fazer parte da vida cotidiana.

Para o sujeito 07, o fato de conviver há 7 anos com o HIV sem que tenha surgido qualquer sintoma coloca em dúvida a existência da infecção.

\begin{abstract}
"Eu acredito nesta doença e, ao mesmo tempo, não acredito. $O$ médico fala que eu tenho, só que eu, por não sentir nada, acho que não tenho nada." (Sujeito 07)
\end{abstract}

Entre o grupo de mulheres que contraíram o vírus há menos tempo, permanece um discurso com base no modelo médico, onde repassam as informações recebidas, ainda que nem sempre compreendidas, conforme relatam os sujeitos 10 e 02, ambas tendo recebido o diagnóstico há 2 anos:

"No meu modo de ver, é uma doença causada pelo vírus $H I V$, que uma vez contagiada não tem mais volta. Destrói as defesas do corpo e coloca outras doenças. Não é a AIDS que mata. Essas doenças matam no lugar dela." (Sujeito 10)

"A AIDS é um vírus, né? Que ataca os órgãos ficando indefeso. É isso que eu sei.” (Sujeito 02)

O processo de construção social da AIDS fica claro na formação do conceito que o sujeito 05 , cujo diagnóstico foi dado também há 2 anos, tem sobre a doença. As reações sociais suscitadas pela doença, constituídas por representações arraigadas, associadas às epidemias do passado, transparecem no seu discurso:

"Eu acho que isso daí, esse vírus, tá que nem o câncer quando saiu. Todo mundo morria de medo, pensava que pegava só de olhar, respirar e já tava. Essa doença também tá a mesma coisa. Só que se evita falar. Eu penso assim também hoje. Tem que esperar as coisas, ver como vai ser, pro pessoal se acostumar com isso, chegar a falar que não é um bicho de sete-cabeças, que é só a gente evitar ele, fazer as coisas direito, fazer as coisas certinhas, pra ter uma vida mais saudável. Não aquela saúde mais, mas ter a coisa mais certa. Mas, se ficar falando pra todo mundo, aí é onde você 
cai em depressão, porque você é rejeitada, aí você fica doente mais rápido, porque você foi rejeitado. Então é onde a pessoa fica mal.” (Sujeito 05).

Apesar do processo de naturalização ou de racionalização em cima do modelo médico, o sentimento de incerteza é uma constante que acompanha a vida destas mulheres no convívio com a soropositividade. Esta incerteza se faz presente no relato do sujeito 06 , diagnosticada há 3 anos:

"Pra dizer a verdade, eu nem sei o que é, nem o que vai ser, nem o que vai virar. Só sei que tenho medo dela. Porque vai trazer problema, não vai? (Sujeito 06).

As situações observadas pela convivência com o HIV por estas mulheres, corroboram os estudos sobre as representações sociais da saúde e da doença conduzidos por Herlich (1991) que concluiu que a luta do sujeito contra a doença é sustentada por dois fundamentos essenciais: a aceitação do fato e o domínio que o indivíduo procura exercer sobre ele. Assim, a doença é tomada como uma situação de aprendizagem, a cura é esperada e a adaptação considerada possível. É observado, também, a necessidade do homem em produzir respostas e sentido, de atribuir causas concebidas em termos não orgânicos, independente da medicina oferecer ou não uma explicação cientifica. Ainda de acordo com esta autora, é através das suas concepções de doença que o indivíduo expressa sua visão de sociedade e sua relação com ela; a doença é o significando cujo significado é extraído da relação do indivíduo com o seu meio social, sendo esta a relação que o indivíduo manifesta quando exprime sua visão do mal biológico.

Ao concluir seu trabalho sobre os sentidos do risco na AIDS, Paulilo (1999) faz os seguintes questionamentos: o que revela este evento que provoca rupturas, 
engendra incertezas, semeia medos, instaura instabilidades, aponta fragilidades e ameaça com a morte? Qual o contexto que a circunda?

Como em tudo o que se refere a AIDS, não existe uma resposta exata. Entretanto, este estudo sobre a soropositividade no cotidiano da mulher nos permite refletir sobre os múltiplos significados por elas atribuído. E, em consonância com os dizeres de Paulilo, pode-se perceber que as razões desta multiplicidade de "sentidos" decorre do

"movimento da história, na dispersão dos espaços, na evolução das práticas sociais. As razões se encontram, pois, na interdependência entre as condições de existência dos homens e a maneira pela qual eles reagem a elas, dando forma e sentido àquilo que o mundo e a vida lhes apresentam. $E$ assim procedendo, dão forma e sentido ao mundo $e$ à vida por eles vividos" (1999, p.39).

Na história da AIDS existem dois períodos bem delimitados: antes da década de 90, quando prevalecia a imagem da AIDS ligada à desesperança e morte; e após, com o uso em larga escala dos medicamentos antiretrovirais (ARVs). Conforme Bessa e Terto Jr.,

"se antes a morte era apenas uma questão de (pouco) tempo, os medicamentos, hoje, estão possibilitando, para milhões de pessoas soropositivas no mundo, o resgate de uma promessa de futuro. É uma promessa que está estimulando uma revisão em vários aspectos da vida das pessoas que vivem - não só, mas especialmente - com o HIV/AIDS. Entre eles os aspectos afetivo e sexual” (2001,p. 01).

Com a expectativa e iminência da morte, o início de qualquer relacionamento era marcado, paradoxalmente, pelo fim, ou seja, a morte de um ou dos dois parceiros. Hoje com o prolongamento do tempo de sobrevida, com a cronicidade da infecção pelo HIV, se impõe uma releitura das estruturas e dinâmicas das relações afetivas. 


\section{B - Relacionamento Afetivo-Sexual}

"Que é paixão? Em Nietzsche, martela e fragmenta, exigindo a transmutação de todos os valores; em Marx, subverte, denunciando a injustiça das estruturas econômicas e sociais; em Freud, revela o inconsciente; $e$, no feminino, desprivatiza o privado para denunciar a desigualdade entre os sexos...

Amor choque, amor loucura, amor incomensurável, amor ardência...tentar falar dele parece-me diversamente, mas não menos terrivelmente $e$ deliciosamente embriagador que vivê-lo. Ridículo? Louco, talvez. O risco de um discurso de amor, de um discurso amoroso, provém, sem duvida, principalmente da incerteza do seu objeto. Na verdade de que estamos falando?" (Kristeva, apud Lobato, 1997, p. 59).

A moldura mais abrangente que concerne à formação do casal é dada pelo amor romântico. O par igualitário tem sua origem explicada por um encontro psicológico singular, apoiado na crença de um sentimento amoroso e que, por esta razão, almeja extirpar outras considerações que não as motivadas pelo sentimento. O casal compreende apoio psicológico, companheirismo e certa regularidade de relações sexuais, mas, sobretudo, procedência sobre as demais relações (Heilborn, 1996).

Sendo assim, como discutir a presença do HIV nas relações conjugais? Como conseguir modificar comportamentos ancorados na afetividade, construídos nas particularidades da vida cotidiana e modelados por marcos sociais?

Diante de uma epidemia, normalmente é a esfera pública que oferece perigo. No entanto, para estas mulheres, foi na intimidade da esfera privada que a contaminação aconteceu.

As representações da doença se contrapõem às representações do amor. A prevenção se introduz como uma proposta de mudança no vinculo do casal, alterando 
o nível de confiança e de contrato. A consciência do risco é vista como um elemento crucial das políticas de prevenção, envolvidas em uma lógica de racionalidade formal. No entanto, não consideram que as pessoas, em geral, não costumam levar em conta a racionalidade na orientação de sua ação. Na prática, parecem ser mais orientadas por idéias e afetos vinculados a determinados padrões definidos.

Partindo destes pressupostos, pretende-se discutir o plano do relacionamento afetivo-sexual, a partir dos relatos de vida, delineados sobre um pano de fundo onde se combinam os diferentes marcos sociais que delimitam o campo das possibilidades destas mulheres: origem e classe social, história familiar e as relações de gênero instituídas no seu cotidiano.

\section{- Iniciação amorosa-sexual}

Para estas mulheres, o inicio da vida sexual não foi um fato isolado, ocorrendo simultaneamente com o casamento ${ }^{9}$, gestação e contaminação pelo HIV (ainda que, na maioria dos casos, só tenham tomado conhecimento de sua soropositividade após algum tempo, como foi visto no tópico anterior). Estes dados podem ser observados na Figura 3.

Constata-se que o início da vida sexual ocorreu, para 50\% das mulheres entre os 12 e 14 anos, sendo o restante entre 15 e 17 anos ( $x=14,3)$. Com exceção de um sujeito, esta primeira relação teve como conseqüência imediata o casamento, cuja tempo de duração variou de um a treze anos, sendo que um deles ainda permanece. Em 50\% dos casos houve ocorrência de gravidez no primeiro ano do relacionamento.

\footnotetext{
${ }^{9}$ Será considerado como casamento, toda relação estável onde existir coabitação.
} 


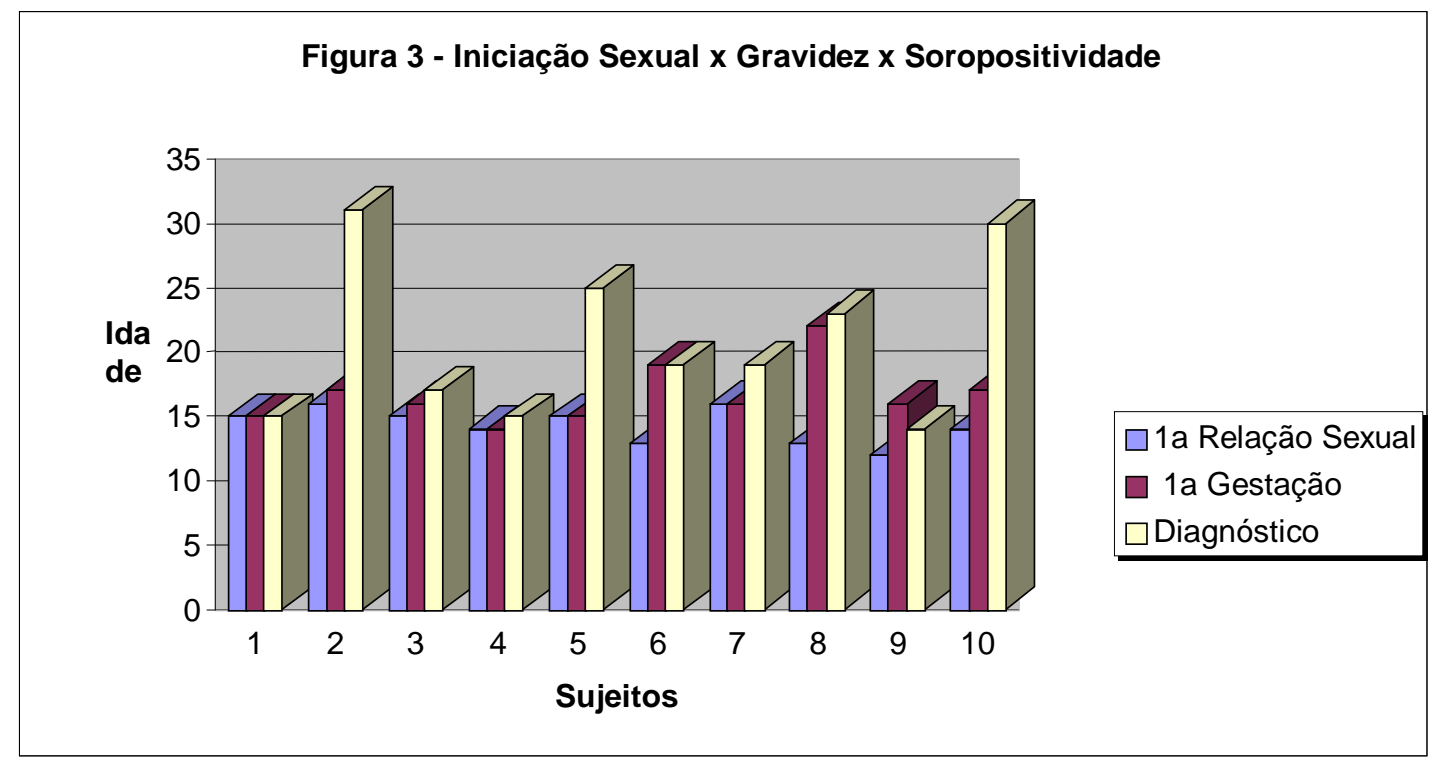

Os motivos relatados para o rompimento do relacionamento foram: $38 \%$ pela descoberta da soropositividade do parceiro, $25 \%$ em decorrência da morte do parceiro, $12 \%$ descoberta da bissexualidade do parceiro e $12 \%$ por violência física e, $12 \%$ casos extra-conjugais do parceiro. Pode-se observar estes dados mais detalhadamente Quadro 4.

Quadro 4 - Algumas Circunstâncias da Iniciação Afetivo-Sexual

\begin{tabular}{|c|c|c|c|c|}
\hline Sujeito & $\begin{array}{c}\text { Idade } \\
1^{\text {a }} \text { Relaçãao } \\
\text { Sexual }\end{array}$ & $\begin{array}{c}\text { Ocorrência } \\
\text { /Idade Gravidez }\end{array}$ & $\begin{array}{c}\text { Duração } \\
\text { Relacionamento }\end{array}$ & $\begin{array}{l}\text { Contaminação pelo } \\
\text { HIV no } 1^{\circ} \\
\text { relacionamento }\end{array}$ \\
\hline 09 & 12 anos & Não & 1 ano & Não \\
\hline 06 & 13 anos & Não & - & Não \\
\hline 08 & 13 anos & Não & 5 anos & Sim \\
\hline 03 & 14 anos & 14 anos & 12 anos & Sim \\
\hline 04 & 14 anos & 14 anos & 1 ano & Sim \\
\hline 01 & 15 anos & 15 anos & 1 ano & Sim \\
\hline 05 & 15 anos & 15 anos & 7 anos & Não \\
\hline 10 & 15 anos & 17 anos & 13 anos & Não \\
\hline 02 & 16 anos & 17 anos & 2 anos & Não \\
\hline 07 & $17 \operatorname{anos}^{10}$ & 17 anos & 4 anos & Sim \\
\hline
\end{tabular}

${ }^{10}$ Foi estuprada por um vizinho aos 16 anos. 
Em estudo realizado por Heilborn (1999), com mulheres de camadas populares, residentes em uma favela do Rio de Janeiro, o sexo apresentou-se como estratégia no estabelecimento de vínculos, possibilitando a realização do casamento, principalmente quando associado a uma gravidez. Segundo a autora, ficou evidente um discurso baseado nas normas de gênero, com a relevância de terem, para si, o respeito social que a formação de uma família traria.

No discurso das mulheres desta pesquisa, observa-se outra ordem de causas profundas, vinculadas por um lado à história de vida e, por outro, ao meio sócioeconômico cultural. Evidencia-se, em suas falas, uma urgência - consciente ou não em abandonar a infância e passar rapidamente à vida adulta, como estratégia de reformulação da situação familiar e compensação das carências afetivas, conforme fica claro no discurso do sujeito 03:

“Meu pai...(...) ele é alcoólatra. Então, eu tinha 14 anos... e ele bebia muito, sabe? Sabe o problema de casa quando o homem bebe? Sabe aquela bagunça? Eu faço de tudo para viver em harmonia em casa, detesto brigaiada, confusão. E ele era de beber e fazer confusão e eu detestava. E eu achei uma forma de eu me casar com 14 anos e essa forma eu achei que ia ser bom pra mim, que eu ia sair daquela coisa ruim lá dentro, sabe?

Relata, inclusive, ter contado com o apoio da mãe:

Quando eu conheci ele eu tinha 14 anos e eu trabalhava, tinha que trabalhar. (...) Quando eu namorava com ele, ela (a mãe) dava força pra mim casar com ele, mesmo tendo 14 anos. (...) Depois que eu tive o menino, ela cismou que ele mexia com drogas. Até hoje ela fala isso pra mim e até hoje eu falo pra ela que ele não mexe. Eu vivo com ele há 12 anos, se ele mexesse, não tinha motivo pra me esconder. (Sujeito 03)

O desejo de ter uma família estruturada, idealizada por ela ao sair da família de origem, faz com que se torne passiva diante de qualquer acontecimento que venha 
a perturbar a ordem por ela estabelecida. Conforme ela relata: “...eu faço de tudo para viver em harmonia em casa." Portanto, nem o fato de ter sido contaminada pelo marido, ou as suspeitas levantadas contra ele pela mãe, são motivos para questionamentos ou confrontos. Conforme Matos (2000), nos relacionamentos íntimos, a confiança estabelecida não vai se basear em regras, procedimentos ou quaisquer outras ordens de formalidade, mas no investimento imediato. Assim, o fato do marido não confidenciar a ela alguma coisa, faz com que isso não exista, como é o caso da suspeita de mexer com drogas relatado pela mãe. Ao contrário, essa acusação torna a mãe uma pessoa pouco confiável:

“Ah! Minha mãe como sempre a revoltada, né? (...) não sei, acho que deve ser o jeitão dela. (...) eu não sei o que passa na cabeça dela, sabe, eu não entendo essa pessoa direito."(Sujeito 03)

A iniciação sexual-afetiva do sujeito 04 não foi muito diferente. Sua história pode ser contada assim: a desestruturação familiar, o alcoolismo do pai, o abandono pela mãe, a humilhação imposta pelo novo parceiro da mãe, a gravidez, a descoberta da soropositividade do marido, seguida de sua morte e, logo após a morte do filho, também soropositivo. Por fim, a solidão e o desamparo. Tudo isso acontecendo até os 15 anos de idade:

"No começo, desde que me conheço por gente, minha mãe e meu pai brigavam muito, aí se separaram. Aí minha mãe arrumou outro homem que era tão ruim, que a gente até preferiu ficar com o meu pai. (...) Acho que eu devia ter 8 anos. (...) Ela (a mãe), assim, nunca foi de dar atenção pra nós, desde que a gente era pequenininho sempre o meu pai estava ali, só que ele era muito desviado por causa da cachaça, que ele bebia muito. E ela arrumou um outro homem e esse homem vivia xingando nós, não queria que entrasse na casa dela, nos humilhava. Nós morava com meu pai, só que o meu pai... aí eu fiz 14 anos. (...) Eu comecei a namorar com ele com 14 anos, aí quando fiquei grávida, meu pai queria que nós casasse (...) aí eu fui morar junto com ele. Aí tive a 
criança, tudo. Aí em setembro eu fiz 15 anos, ele já tava doente (...) e quando foi em novembro ele morreu. (...) Aí foi quando aconteceu de o neném ter morrido em março.” (Sujeito 04)

A (des)organização familiar, a situação sócio-economica, a falta de perspectiva, a ausência de afeto e cuidado, enfim, as condições em que se desenvolveu a sua infância, empurrou-a ao crescimento acelerado, passando da infância diretamente para a vida adulta através do casamento.

Assumir responsabilidades excessivas em idade precoce também pode levar a uma ruptura com a infância, levando-as a assumirem os papéis adultos que lhes foram designados (trabalho externo, tarefas domésticas, cuidar os irmãos), também em relação a sexualidade e vínculos afetivos, conforme pode ser observado no relato do sujeito 10:

"Com 9 anos eu já trabalhava. Meus pais tinham muitos problemas. Meu pai estava sempre doente, com epilepsia, sempre caia duas, três vezes por dia. Então eu tinha muita falta, muita fome. Comecei a trabalhar com 9 anos em casa de família, empregada olhando criança. Com 12 anos eu larguei a escola pra trabalhar mais, num período maior. Aí fui trabalhar na roça, colhendo algodão, café, tudo. Até os 15 anos. Com 15 anos saí de casa pra morar com meu primeiro marido. Vivemos juntos de 84 à 95. Eu adorava ele. A minha vida era ele. Por isso acho que durou tanto tempo com tudo o que aconteceu, as traições, as saídas dele...

Nos discursos destas mulheres estão sempre surgindo referências aos papéis e normas de gênero fortemente estereotipados, como por exemplo, quando o sujeito 10 refere-se às saídas e traições do marido. Persiste um sistema de normas e valores em relação aos papéis masculino e feminino, na divisão dos espaços de ação, domésticos e públicos. Particularmente na cultura brasileira, pode ser observado que a construção simbólica da masculinidade inclui a multiparceria, ainda que velada e 
não abertamente admitida, e da identidade feminina fazem parte traços como a timidez, a fragilidade, o conformismo e a fidelidade.

É interessante observar que, apesar da pouca idade e mesmo tendo atitudes independentes antes do casamento, além do contato com a mídia que sempre enaltece a mulher autônoma, ao casar, estas jovens passam a viver de acordo com as expectativas relacionadas ao modelo de ser mulher associado ao estereótipo da esposa/mãe compreensiva e conformada com a vida privada, calando mesmo diante de situações que requerem uma atitude mais autônoma em relação a sua vida sexual e afetiva.

Esta situação remete à Parker (2000), quando diz que, apesar da monogamia ser um requisito fundamental para a formação do núcleo conjugal legitimo - no casamento baseado em modelos e valores tradicionais que reeditam a dupla moralidade sexual originada do patriarcalismo - o adultério masculino, apesar de não ser algo comumente revelado é, de certa forma, seja por dependência afetiva ou econômica, tolerado pelas mulheres.

Em muitos casos, conforme salienta Araújo (2000), a fidelidade é uma questão de envolvimento. Portanto, não existirá traição se a relação for apenas sexual, se não houver envolvimento amoroso. Esses são elementos importantes para que as mulheres possam manter a relação, reconhecendo no seu relacionamento a solidez de um afeto que permite acontecer a continuidade do relacionamento.

Em seus estudos, Guimarães (1996), constata que, embora a infidelidade masculina seja quase uma certeza nas relações amorosas, ao ter conhecimento, ainda 
que veladamente, as mulheres têm a auto-estima abalada e seus sentimentos são de dor e abandono.

Neste aspecto, Saffioti (1969), analisa a desigualdade social entre homens e mulheres como, talvez, a mais fundamental de todas as desigualdades, cuja persistência, através dos séculos, demonstra quão enraizada e infiltrada ela permanece até os dias de hoje, malgrado às lutas pela sua extirpação, travadas no plano coletivo, pelos movimentos feministas e no plano individual, por mulheres de diferentes idades e classes no cotidiano de sua vida.

Neste grupo de mulheres entrevistadas, o sujeito 06 foi a única para quem a primeira relação sexual não se tornou relacionamento estável. Ela relata a ocorrência de seis parceiros temporários antes de casar-se, aos 19 anos, grávida.

"Na verdade, eu não tive infância, não era menina de ficar brincando.(...) Pra você ver, eu tive minha primeira relação com 13 anos. Eu nunca me senti criança, queria me sentir mais adulta, assim, sabe? Com 10 anos eu ia à discoteca, saia, gostava de sair com mulheres mais velhas, casadas. Eu sou a mais velha de cinco irmãos. Aí, com 19 anos eu fiquei grávida, aí casei." (Sujeito 06)

No discurso de todas estas mulheres, a gravidez é apresentada como algo imprevisto, ocorrendo uma aparente inconsciência quanto à possibilidade de gravidez, embora não desconhecessem os métodos preventivos e tivessem como meta o casamento. Palma \& Quilodrán (1994), em estudo sobre a gravidez adolescente, concluíram que a gravidez nesta situação apresenta-se como situaçãolimite, modificando drasticamente as biografias, expondo as adolescentes a um radical e inevitável momento de encarregar-se de si própria. A maternidade surge, para estas autoras, como conteúdo do casamento que racionaliza e dá sentido à reinserção da ordem, ou seja, uma possibilidade imediata de coordenação e de 
assumir papeis adultos, ser e operar como adulto, constituindo a manifestação mais visível e imediata de novas responsabilidades a serem assumidas.

Em relação às mulheres analisadas nesta pesquisa, observa-se também uma situação-limite, onde a gravidez surge como conteúdo do casamento. Entretanto, o casamento não apenas dá reinserção da ordem formal, através de sua legitimação. $\mathrm{O}$ casamento, mais do que este aspecto, representa uma mudança de vida em suas versões mais idealizadas. A valoração e a expectativa do casamento aparece como condição necessária para superar a situação de vida precária, não apenas no sentido econômico, mas principalmente o afetivo, e, assim, realizar seu desejo de formar uma família, ter uma casa e, mais do que tudo, ter um marido que além de provedor, supra sua carência afetiva. A convivência no casamento parece oferecer uma base para a construção da afetividade.

Assim, a gravidez se apresenta como indicador concreto de compromisso afetivo (Leal \& Fachel, 1999), ou seja, a valorização da gravidez é redimensionada ou reissignificada, não funcionando mais apenas em termos da essencialidade identitária do feminino, mas também em termos de elemento fundamental em uma rede de arranjos domésticos, de consangüinidade, afinidades, papéis, prestígios sociais e afetos. A gravidez seguida de casamento, surge como uma estratégia de aliança que lhe permite compensar e redimir suas carências afetivas.

A iniciação sexual, para os sujeitos 07 e 09, se deu através de violência, nos dois casos por homens mais velhos e conhecidos. No caso do sujeito 07, a violência sexual se deu por um vizinho:

"Nasci no Mato Grosso, minha mãe tinha muitos filhos e então me deu para uma mulher criar. A mulher me criou até a idade de 16 
anos. Aí o vizinho da casa da gente me estuprou. Aí eu não gostei, fui morar no emprego e depois vim trabalhar aqui em R.P., na casa de uma patroa."

O sujeito 09 foi vitimizado sexualmente pelo próprio marido, com quem casou pensando em melhorar sua vida:

"Na minha infância, meu pai levava a gente pra roça, sabe, a gente trabalhava mas se divertia muito. (...) Aí fui crescendo (...) ...meus irmãos brigavam muito comigo. (...) Minha mãe cuidava de três sobrinhas, sempre a atenção era pra elas e eu apanhava muito por causa delas. (...) eu era a culpada de tudo. Fui saber que meus pais eram adotados com 15 anos. (...) Meu primeiro namorado foi logo, assim, o rapaz da esquina. Eu não lembro quantos anos eu tinha, mal eu tinha me formado. Aí eu fui morar com ele, achei que minha vida ia melhorar, mas só piorou mais. Eu lembro que sofri muito nas mãos dele, ele me batia, tudo.(...) eu tinha uns 12, 13 anos. Não foi legal (a primeira vez), sabe por que? Ele já chegava bêbado em casa, me pegou de tudo quanto era jeito, foi horrível."

Depois de alguns meses sofrendo abusos, ela tentou voltar para a casa dos pais, mas não foi aceita. Acabou fugindo e passou a morar na rua até que conheceu um rapaz com quem veio embora e casou. O ex-marido, neste período, foi assassinado.

Como pode ser percebido através destes relatos, apesar de vitimas da violência, ambas tiveram como reação a fuga, o afastamento e o silencio, enquanto os agressores permaneceram impunes. Os aspectos sócio-culturais constitutivos da representação da sexualidade feminina leva a mulher a uma atitude de total silenciamento frente à determinadas situações de confronto. Este silencio decorre, não só do pudor que envolve um fracasso interpessoal (Prado \& Oliveira, 1982), mas também da ausência de consenso sobre a validade ou não da punição que um homem pode aplicar à sua mulher. Entre estes limites, encontra-se uma série de 
comportamentos cotidianos, desde pancadas superficiais até agressões graves, passando pela agressão sexual, violação ou estupro no matrimonio.

Além disso, Prado \& Oliveira (1982), assinalam que devido ao nosso histórico social, mantém-se ainda no inconsciente masculino a crença em seu direito de impor e exigir determinados comportamentos e, reciprocamente, no inconsciente feminino, a culpa em relação a deveres não cumpridos. E ainda, a idealização interiorizada da realização pessoal, através da felicidade no lar, fazendo com que as mulheres escondam as situações conflitivas de seu cotidiano.

A violência física familiar contra a mulher, de acordo com Azevedo (1985), se explica por diversos fatores, de ordem condicionante e caráter precipitante, mediadas por um padrão assimétrico de relações de gênero. Os fatores precipitantes incluem o uso de álcool, drogas e situações de stress. Dentre os fatores condicionantes encontram-se os de ordem:

- estruturais: formas concretas de opressão do regime sócio-econômico e político, aos quais homens e mulheres estão sujeitos;

- institucionais: o caráter discriminatório contra a mulher nas instituições ligadas à vida e à segurança, como a família,direito, justiça policia;

- ideológicos: a ideologia machista que normatiza as relações entre os sexos como relações de poder;

- pedagógicos: a educação diferenciada dado à meninos e meninas que incorpora o mito da superioridade masculina versus a inferioridade feminina;

- individuais: a representação ideologizada das relações entre os sexos elaboradas por membros de famílias violentas. 
Em todos os relatos fica claro que o amor é buscado no casamento. O casamento teve para elas a função de prover cuidado, oferecendo um lugar de paz e harmonia. Como instituição, o casamento apresenta o amparo e o conforto de tudo aquilo que é aprovado socialmente. A sua representação contém elementos do amor romântico, ainda que contendo fortes contradições, pois se as forças ideológicas sustentam a visão idílica do casamento como lugar do amor, as contradições no cotidiano afloram. Mesmo na atualidade, as mulheres ainda buscam o romance como a busca do destino (Giddens, 1993), ainda que isso não signifique mais o adiamento da atividade sexual até que o relacionamento desejado apareça. Se a busca do romance não é mais para estas mulheres um conjunto passivo de aspirações, não deixa de ser um processo ativo de engajamento com o futuro, ainda que para isso precisem recuar para idéias e modos de comportamentos pré-existentes, como aceitação do padrão duplo, submissão, etc.

\section{- Manutenção ou Rompimento do Primeiro Casamento}

Sendo o casamento a concretização dos seus desejos, torna-se difícil desistir dele, constatando o fracasso de suas expectativas, ou seja, é a perda da ligação sobre a qual ela buscou seus sentimentos de segurança e realização.

Como já foi observado neste grupo de mulheres, apenas os sujeitos 02 e 03 mantêm o primeiro relacionamento até os dias atuais, mesmo após a certeza de ter sido contaminada pelo HIV através do marido. O sujeito 04 permaneceu com o marido até sua morte. Entretanto, para os sujeitos 01, 07 e 08, também contaminadas através do parceiro no primeiro relacionamento, só teve fim ao saber o diagnóstico soropositivo do parceiro, conforme pode ser observado no Quadro 5: 
Quadro 5 - Rompimento ou Manutenção do Primeiro Casamento

\begin{tabular}{|c|c|c|}
\hline Sujeito & Atitude & Causas \\
\hline \multicolumn{3}{|c|}{ Decorrente da Soropositividade } \\
\hline Suj. 01 & Rompimento & Descoberta soropositividade do marido \\
\hline Suj. 02 & Manutenção & Mantém relacionamento até hoje \\
\hline Suj. 03 & Manutenção & Mantém relacionamento até hoje \\
\hline Suj. 04 & Manutenção & $\begin{array}{c}\text { Manteve relacionamento até morte do marido } \\
\text { soropositivo }\end{array}$ \\
\hline Suj. 07 & Rompimento & Descoberta soropositividade marido \\
\hline Suj. 08 & Rompimento & Descoberta soropositividade marido \\
\hline \multicolumn{3}{|c|}{ Outros motivos } \\
\hline Suj. 05 & Manutenção & Morte marido acidente carro \\
\hline Suj. 06 & Rompimento & Bissexualidade marido \\
\hline Suj. 09 & Rompimento & Violência física/sexual \\
\hline Suj. 10 & Rompimento & Casos extra-conjugais marido \\
\hline
\end{tabular}

É importante observar que a separação, independente da presença da soropositividade, só se realiza ao se esgotarem todos os recursos de continuidade, como no exemplo do sujeito 10, cujo primeiro relacionamento se manteve durante 13 anos:

"Foi um casamento muito bagunçado, muitas idas e voltas, muita desilusão, muitas coisas que hoje eu não viveria de novo. (...) as traições, as saídas dele que nunca estava em casa, tudo o que eu fazia e trabalhava e lutava pra construir pra nós e nossos filhos ele jogou tudo fora da noite pro dia. (...) A última vez que a gente voltou foi em 93. Eu já não queria mais. Tentei dar uma ultima chance. (...) Aí em 95 ele aprontou outra. (...) Então eu disse: Sai daqui! Foi a última vez que a gente teve junto. Depois disso ele visitava sempre os meus filhos e só. Mas ele se achava meu dono. Ele não se achava meu marido, se achava meu dono."

As mulheres, em geral, cuidam mais da relação, preocupando-se em conversar, discutir, negociar. Identifica-se aqui, mais uma vez, a figura da mulher 
como a eterna cuidadora. É ao elemento feminino que cabe a responsabilidade pelo bem-estar da família. Esse aspecto fica mais evidente quando o sujeito 10 deixa claro, no discurso abaixo, não ter tomado esta atitude antes devido aos cuidados com os pais. Com a morte deles, ela teve mais tempo e disposição para cuidar de si.

"Tinha meu pai e minha mãe que eu cuidava também na época, então... durou tudo isso. Até que fechei, parei aqui."

A expectativa em relação ao papel feminino sempre foi o de acolhedora das necessidades dos outros, o marido, os filhos, os pais, os doentes, etc. E, muitas vezes, quando conseguem romper com este esquema, sobrevém a culpa por não estarem cumprindo com seus múltiplos papéis. Analisando pelo ângulo desta hierarquia de cuidados, cabe questionar sobre o que significa o auto-cuidado para estas mulheres.

É em função do marido e dos filhos que estas mulheres constroem seu mundo e, através deles, constroem sua identidade. O casamento torna-se, assim, o valor de extrema importância em suas vidas. A dissolução do vinculo traz danos e sofrimentos muito mais intensos, o que as faz manter o caso apesar do conflito entre risco e proteção que permeia a relação. Segundo Paulilo (1999), esta seria uma explicação possível, inclusive para tantas mulheres financeiramente independentes, que conservam um relacionamento conflituoso.

Para o sujeito 06, o rompimento do relacionamento se deu pela descoberta da bissexualidade do parceiro:

“... ele era desses caras que, assim, ele ia pros homens também. Ficava com um, ficava com outra. Por isso que eu larguei dele." 
A sexualidade é um domínio cercado por tabus, mistérios, proibições, sendo controlados não tanto no âmbito do legislativo (Ávila \& Gouveia, 1996), mas das relações cotidianas, através da influência da religião, família, mídia, medicina, etc.

No Brasil, a cultura do machismo, ou seja, "o complexo sistema ideológico que organiza as relações de gênero, hierarquicamente, estabelecendo relações de poder e domínio dos homens sobre as mulheres" (Parker, 2000, p.80), também estrutura as interações com o mesmo sexo, por linhas de atividade e de passividade. De acordo com Parker, “as relações sexuais entre homens são conceitualizadas dentro da estrutura de relações de masculinidade e feminilidade, e o papel sexual dos parceiros como sendo ativo (penetrando) ou passivo (penetrado) é, de certo modo, mais importante que a escolha do objeto sexual (macho ou fêmea) para definir noções de identidade sexual e o valor social.” (2000, p. 81). Admite-se, portanto, que um homem possa ter relações sexuais com outro homem e, desde que seja o ativo, preservar a identidade masculina. Entretanto, os sujeitos passivos, por assumirem o papel das mulheres, são estigmatizados.

No tocante à bissexualidade, por ser intermediária, permanece marginal e obscura, sendo vista mais como uma variação da homossexualidade, do que uma extensão do desejo heterossexual, tornando-se alvo de desconfiança, onde a atração por mulheres cumpriria apenas a função de resguardar a masculinidade (Lago, 1999).

Segundo esta mesma linha de análise, Herrera e Campero (2000), colocam a bissexualidade, em alguns casos, tendo como contraponto e causa direta a homofobia, a discriminação social à homossexualidade, o que obriga alguns homens a levar uma vida dupla, ou seja, ter práticas homossexuais ao mesmo tempo em que mantém uma imagem social de heterossexuais, inclusive perante si mesmos. Mais 
ainda, em certos contextos culturais, ainda se acredita que tomar parte "ativa" em uma relação entre homens, não somente deixa intacta a identificação com a heterossexualidade, mas ainda reforça a fama de "macho".

Em determinados casos, este ocultamento da bissexualidade implica na procura de lugares clandestinos, comumente precedidos por forte consumo de álcool ou drogas, substâncias que liberam, mas ao mesmo tempo relaxam os cuidados (Herrera e Campero, 2000). Estes fatores dificultam a prevenção ao HIV, determinando práticas sexuais de risco, aumentando a vulnerabilidade de homens e mulheres, através de influências direta e indireta.

Estas considerações são importantes quando considerados os projetos de intervenção no âmbito do HIV/AIDS, visto que os fatores que compõem a sexualidade brasileira não podem ser considerados apenas como questão de comportamento individual e sim como parte de um processo complexo de transformação sócio-cultural.

\section{- Sentimentos decorrentes da contaminação: manutenção ou rompimento do vínculo afetivo}

A manutenção ou rompimento do relacionamento em decorrência da soroposividade para o HIV, depende, basicamente, de dois fatores:

- se o parceiro já tinha conhecimento do diagnóstico e não comunicou, ele é culpabilizado e a conseqüência é a separação.

- se ele não sabia do diagnóstico, ela torna-se cúmplice por ter aceitado determinadas situações. Além disso, o fato de gostar faz com que seja perdoado. 
O primeiro caso pode ser exemplificado pelos discursos dos sujeitos $07 \mathrm{e}$

08:

"...ele, na hora que a enfermeira falou, ele disse que fazia oito anos que ele fez um teste e que ele tinha e eu não sabia." (Suj. 07)

“...eu falei pra ele que fiquei muito triste por ele ter escondido e ele falou que foi porque me amava demais e que se ele falasse eu não ia ficar com ele. Aí eu disse que ele não podia fazer isso, que não é porque ele vai pro inferno que vai me levar junto. Ele tinha que ter sentado comigo e conversado. Ele sabia, então ele tinha que ter falado. Eu gostava dele, tanto que eu fiquei com ele ainda. Mas depois o amor foi acabando..."(Suj. 08)

Revelar a soropositividade, na maioria das vezes, se apresenta como um dilema que traduz o medo de não ser aceito como companheiro devido ao HIV. Entretanto, segundo Polejack (2002), mais do que o impacto do diagnóstico, o desgaste do relacionamento está vinculado ao conviver com a soropositividade. É o dia-a-dia, são as questões relacionadas ao HIV que vão surgindo e não são trabalhadas, não são discutidas, não têm espaço para existir, que trazem a dificuldade para o casal. Além disso, existe a convivência com o paradoxo saúde/doença, vida/morte com o qual o casal convive o tempo todo.

Para o sujeito 01 a soropositividade do parceiro não era motivo para separação, embora ele já soubesse do diagnóstico. Entretanto, devido a pouca idade, 15 anos na época, separaram por imposição de sua mãe.

"Sabe, todo mundo comentava, mas ele nunca apresentou nada, parecia uma pessoa normal. A mãe dele também falava que não, que isso era os outros que falavam. Então, eu acreditei nele, acreditei na família dele. Mas era verdade o que os outros falavam. Quando minha mãe ficou sabendo fez eu largar dele, aí nós largamos. Eu não culpo ele porque eu gostava dele." 
A confiança no parceiro, aliada ao fato do relacionamento ser exclusivo, forma a base da infecção destas mulheres. O amor e a paixão apresentam um componente que emerge a partir da construção de um sentimento de invulnerabilidade, típico de pessoas apaixonadas. Elas se sentem de tal maneira plenas, poderosas, que vem-lhe a certeza da invulnerabilidade; nenhum mal pode advir de alguém que é sujeito e objeto de sua paixão. Além disso, o risco trazido pelo parceiro se insere no universo amplo dos riscos aceitáveis e perdoáveis decorrentes do ato de amar.

Os sujeitos 04 e 05 se enquadram no segundo caso citado, onde o fato do parceiro não ter conhecimento da soropositividade e, principalmente, por ter ocorrido, segundo ele, em relacionamentos anteriores, não configurando traição, faz com que não seja culpado.

"Ele não sabia. Eu não sabia. Ninguém sabia. Nós só fomos ficar sabendo quando ele começou a ficar doente. Aí eu continuei ajudando, o que eu podia fazer, eu fazia. Eu não me preocupei comigo, preocupei em ver ele naquela situação que eu tava vendo." (Suj. 05)

A dedicação do sujeito 05 para com o marido fez com que seu próprio estado de saúde passasse para um plano secundário. Toda sua energia era gasta no cuidado com o marido. Como a maioria das mulheres, ela carrega este papel, culturalmente imposto, de cuidadora. Nas situações de crise ou doença, é ao elemento feminino que cabe a responsabilidade pelo bem estar dos seus.

A recorrência ao amor que sente pelo marido justifica a permanência do sujeito 04 ao lado do marido:

"No começo eu senti revolta, mas assim, eu mesma fui enxergando que as coisas não é assim... com qualquer um ta arriscado a 
acontecer isso, podia ser com outro... (...)é difícil aceitar, mas eu não tenho outras opções pra mim, se eu brigar com ele, prá viver brigado não vai dar certo, porque eu tenho esse problema. Se eu largar dele também não tenho pra onde ir... Se eu não gostasse dele, eu não estaria com ele, eu não aceitaria. Se existe amor você tenta achar um lado, um motivo pra o que aconteceu. Eu acho que o que aconteceu pode não ser uma falha dele, pode acontecer com qualquer um, porque ta arriscado a acontecer.”(Suj.04)

Neste discurso, a manutenção do relacionamento está ancorada em três aspectos: o amor, a fatalidade da contaminação (poderia acontecer com qualquer um) e na ausência de recursos materiais.

A vulnerabilidade das mulheres na questão de gênero se reforça, de acordo com Herrera e Campero (2000), quando somadas a outras desigualdades, como a pobreza ou a discriminação por razões étnicas ou de preferências sexuais. Ou seja, o HIV/Aids afeta as mulheres enquanto mulheres, porém não afeta a todas por igual. Se bem que existe uma vulnerabilidade especifica para as mulheres, aquelas que estão particularmente em risco são as que tem "vulnerabilidades acumuladas", o que muitas vezes as obriga a praticas sexuais de sobrevivência ou a tolerar maltratos que, em uma situação de menor vulnerabilidade, não tolerariam. Gênero, origem étnica, situação sócio-econômica, status de cidadania, entre outras formas de discriminação se combinam para formar situações de extrema vulnerabilidades.

Vale ressaltar que a vulnerabilidade não se dá somente no aspecto de maior viabilidade de transmissão, mas também nos momentos subseqüentes, através da manutenção dos riscos no contexto dos relacionamentos, possibilitando a reinfecção.

Pelos relatos até agora apresentados, pode-se observar que os valores de gênero e os valores sociais, como conjugalidade, maternidade, e a importância atribuída à família, se sobrepõem à Aids em vários níveis, fazendo emergir 
dificuldades já existentes no relacionamento e agravadas pela revelação da soropositividade. Categorias polares, contraditórias, permeiam a vida cotidiana, como culpa e absolvição, raiva e pena, vitima e cúmplice, confiança e risco, dúvida e crença. O risco tornou-se uma das referências da vida, refletido em comportamentos de afastamento, aproximação e, ainda, paradoxalmente revelado em atitudes simultâneas e ambivalentes de evitação e busca.

Estes fatores ficam evidentes na narrativa do sujeito 02 sobre seu casamento: casada há 9 anos, descobriu seu status soropositivo há 3 anos, durante o pré-natal de sua segunda filha. É ela quem sustenta a família administrando uma pensão de sua propriedade.

"Depois de um ano que a gente tava morando junto, ele começou com as drogas. Começou e não parou. Aí, quando a gente tava com quatro anos, descobri com certeza, ele tava mesmo afundando. Aí eu fiquei grávida com ele mesmo usando drogas. Tanto é que eu falava pras minhas vizinhas: Minha filha devia se chamar Crackinha... Porque ele só fazia drogado. A gente só tinha relação quando ele tava drogado. (...) aí ele começou a chegar realmente de madrugada, chegava sempre drogado..."

É sabido que os usuários de drogas injetáveis (UDI) têm um importante papel na transmissão sexual e vertical do HIV, observando-se que $20 \%$ de Aids entre mulheres brasileiras nos últimos anos têm o uso de drogas como categoria de exposição (Boletim Epidemiológico - CNDST/AIDS, 12/2003). O auto-cuidado do indivíduo que usa drogas pode sofrer prejuízo, o que está relacionado, de acordo com Sampaio (2002), com o estilo de vida. Além disso, o consumo de drogas contribui para banalizar alguns conceitos de auto-preservação e muitas vezes reforça, no usuário, conteúdos como poder, onipotência e valentia, aumentando assim o potencial de vulnerabilidade. Nesta interface drogas e Aids, um fator importante se 
refere aos relacionamentos onde o homem é usuário de drogas e mulheres que, apesar de não serem usuárias, compartilham indiretamente dos riscos.

Esta questão remete à reprodução dos papéis tradicionais de gênero, no que Bastos (2002) denomina "dialética da cumplicidade". De acordo com este autor, existe uma completa interface entre cumplicidade e intimidade, no sentido da compreensão mútua, da tolerância de existir uma história compartilhada quando as pessoas são íntimas umas das outras. Ressalta, entretanto, a necessidade de observar que esta cumplicidade pode ser negativa, com o encobrimento de faltas, ou seja, uma situação de cumplicidade fundamental no hiato entre a esfera privada, em que os hábitos de consumo de drogas são legítimos aos olhos do praticante e uma dimensão publica em que tais hábitos são condenáveis, tanto no sentido moral da sociedade, como jurídico.

"Esta liminaridade entre o moral e o imoral, o licito e o ilícito, o legítimo e o ilegítimo é complexa, e tanto pode fomentar a solidariedade e a busca de transformação, como a inércia e a negação dos riscos e da vulnerabilidade" (Bastos, 2002:121).

Esta questão tem desdobramentos, inclusive no âmbito da prevenção da transmissão vertical. Ainda que, sem dúvida, a mais bem sucedida iniciativa da saúde publica na área do HIV/AIDS, com a redução da transmissão à níveis baixos, cabe observar uma série de particularidades quando entra em cena o uso de drogas, que estão vinculadas a uma série de questões psicossociais das mulheres e suas parcerias.

Segundo Bastos (2000), sobressaem assim "os efeitos sinérgicos e perversos das desigualdades sociais e de gênero, marginalização e estigmatização. Tudo isso contribuindo para que a aderência aos protocolos seja problemática ou mesmo inexistente" (p. 122). 
Não resta dúvida que existe um importante viés social e de gênero que leva à negação do risco, conforme pode ser observado na continuação do relato do sujeito 02:

“...quando eu separei e voltei, até minha cunhada chegou pra mim e falou assim: você não tem medo do que ele pode trazer pra casa? Eu nunca imaginei, eu confiei na pessoa. Eu nunca imaginei que ele pudesse ir lá na rua enquanto eu trabalhava, tinha minha filha com 5 meses..."

E, apesar da revolta e pedido de explicações ao parceiro no momento do conhecimento do diagnóstico soropositivo (“...eu gritava pra ele: como isso aconteceu? Você quer me contar o que aconteceu? Você me deve uma explicação!”) e da certeza expressa de ter sido contaminada pelo parceiro ("eu sei o que fiz"), o rompimento do relacionamento não é sequer cogitado e logo surge a cumplicidade, agora também pela soropositividade:

"Eu fui cúmplice, aceitei a situação dele. Então eu não posso dizer que odeio ele e fingir que não sabia de nada. Que isso não poderia acontecer. Seria hipocrisia... Lógico que mexe. Quando eu to nervosa, te dá crise de depressão. Você vai acusar ele, você vai falar: você é o culpado de tudo o que se passa. De eu, por exemplo, eu ter pego uma doença, de eu ter que morrer.(...) Mas, de certa forma, a gente ta mais cúmplice um do outro. Em vez de ficar apartado, a gente ta mais cúmplice... Eu aceitei, não aceitei?"

Observa-se no discurso do sujeito 02 que, ao mesmo tempo em que valoriza os sentimentos que a liga ao companheiro, incorpora uma culpa de caráter individual por ter se envolvido em tal tipo de relacionamento.

Segundo análise de Paulilo (1999), mulheres casadas com homens soropositivos desenvolvem, a partir da representação da vulnerabilidade masculina, uma argumentação que justifica os comportamentos masculinos e a manutenção da 
aliança conjugal. As representações femininas sobre o gênero masculino vêem o homem como um ser naturalmente livre, habitante dos espaços públicos, possuidor de imperativos sexuais muito fortes e avessos a vida doméstica. A perspectiva essencialista da "natureza masculina" justifica o gosto pelas drogas, álcool, sexo. O papel da esposa e a vulnerabilidade masculina são os principais argumentos que sustentam a lógica da manutenção do vinculo conjugal depois do conhecimento da contaminação do casal.

Ao retratar estes aspectos como acontecimentos "naturais", a ideologia opera através do que Thompson (1995, apud Roso, 2000), chama de reificação, que é a naturalização ao enaltecer e reforçar o comportamento viril masculino. Esta cultura sexual adquire então, uma rigidez difícil de ser quebrada, cristalizando-se na vida social de tal forma que sua origem sequer é questionada.

Como conseqüência desta construção social de gênero, emerge no discurso do Sujeito 02, um dos papéis sociais destinados à mulher, o de "cuidadora", assumindo inclusive a responsabilidade pela contaminação do parceiro:

"Ele tinha uma vida noturna dele que eu não proibia. Aí foi o meu grande erro. Talvez se eu pegasse um pouco mais, quem sabe diminuiria um pouco a chance de..."

Segundo Balandier (1994), as dificuldades que o indivíduo enfrenta para se definir, para se situar, para preservar sua autonomia, fazem com que ele se torne seu próprio produtor de significações, "o artesão-brincouler das representações do mundo no qual ele se encontra presente" (p. 25-26). Ele as constrói, em certo sentido sob o impulso das circunstâncias, das necessidades imediatas e também das influências recebidas. 
Neste sentido, a soropositividade trouxe para o Sujeito 02 a possibilidade de re-significar o seu casamento e a sua vida, passando de vítima da contaminação à cúmplice tão ou mais responsável do que o parceiro, inferindo ganhos no status relacional. Isso permite também que a raiva que sentia pelo marido se converta em compaixão.

“...eu até fico com dó por a gente ter pego, principalmente por ele ter pego isso, sabe. É uma pessoa que nunca fez mal pra ninguém, é uma pessoa até boba demais. Pra ser sincera, uma pessoa boa. Tem um gênio bom.(...)Ele não tá mais cometendo tantos excessos como ele cometia. As drogas que eram maiores ele já diminuiu bastante. Ele vai lá, compra uma porcaria e fuma. Toma uma cervejinha e vai deitar. Coisa que ele não fazia antes."

Segundo Matos (2000), a identificação com o que sofre revela articulação dupla entre cultura e identidade. Por um lado, é o eixo organizador para a trajetória daqueles que se encontram, por força das circunstâncias, excluídos, Por outro lado, irmanar pelo sofrimento, ou ainda, pelo compartilhar a transgressão, constitui vínculo de solidariedade mais tolerante. Na medida em que é possível se colocar no lugar do outro, seja pelo amor e tentativa de compreende-lo, seja pela empatia por seu sofrimento, ainda que não de uma forma premeditada, racional ou intencional, reforçam-se os laços.

Entretanto, os sentimentos contraditórios e a ausência de confiança, persistem. Surge a necessidade de lembrá-lo da culpa, que pode ser visto como uma forma de manter o poder adquirido pela contaminação.

"Não vou negar que hoje, quando ele pisa o pé fora de casa, eu já fico assim, sabe. Tem vezes que até saio pra vigiar, ver o que ele ta aprontando, o que ta fazendo. Você alerta: olha! Eu já te perdoei a primeira vez, na segunda não vai ter chance. Porque, de certa forma, ele condenou a família, poderia ter pensado um pouquinho 
mais.Porque ta certo que ele é bom hoje, que se prontifica a olhar as crianças, mas a culpa foi dele." (Sujeito 02)

Através dos discursos evidenciam-se padrões culturais dominantes, onde o desejo de ser amada, de receber afeto, ser cuidada, aparece no horizonte feminino como mais importante que os possíveis riscos, combinando com o lugar social designado à mulher, onde "são menores os direitos e maiores as obrigações" (Ferreira, 1999).

Pode constatar-se que estas mulheres não foram contaminadas porque não entendem os riscos. Fica claro um processo de negação do risco, o que vem a ser paradoxalmente, um processo de compreensão do risco. O risco do HIV foi, portanto, compreendido dentro do universo cultural, social, individual próprio de cada uma delas, a partir de suas experiências subjetivas e intersubjetivas.

\section{- A Dinâmica das Relações Afetivas Atuais}

Com base nas entrevistas realizadas, apenas duas mulheres mantêm o primeiro casamento. Das restantes, 06 estão vivendo novos relacionamentos estáveis, sendo que apenas duas iniciaram estes relacionamentos tendo conhecimento da soropositividade, conforme pode ser observado no Quadro 6.

De acordo com estudo de Caballo (1987), citado por Pinezi-Barbosa (1999), os aspectos reforçadores dos relacionamentos conjugais, ou seja, mais conseqüências recompensadoras do que negativas e a reciprocidade do casal na emissão de reforçadores, possibilitam a manutenção do relacionamento, maximizando na qualidade. 
Quadro 5 - Relações Afetivas Atuais

\begin{tabular}{|c|c|c|c|}
\hline Sujeitos & Situação & $\begin{array}{c}\text { Tempo de } \\
\text { Relacionamento }\end{array}$ & $\begin{array}{l}\text { Sorologia do } \\
\text { Parceiro }\end{array}$ \\
\hline 02 & Manutenção do $1^{\circ}$ casamento & 9 anos & $\begin{array}{c}\text { Recusa fazer } \\
\text { teste }\end{array}$ \\
\hline 03 & Manutenção do $1^{\circ}$ casamento & 10 anos & $\begin{array}{c}\text { Recusa fazer } \\
\text { teste }\end{array}$ \\
\hline 05 & $\begin{array}{c}\text { Novo relacionamento antes do } \\
\text { diagnóstico }\end{array}$ & 3 anos & Soropositivo \\
\hline 10 & $\begin{array}{c}\text { Novo relacionamento antes do } \\
\text { diagnóstico }\end{array}$ & 4 anos & $\begin{array}{l}\text { Aguarda } \\
\text { resultado }\end{array}$ \\
\hline 06 & $\begin{array}{c}\text { Novo relacionamento antes do } \\
\text { diagnóstico }\end{array}$ & 3 anos & Soronegativo \\
\hline 08 & $\begin{array}{c}\text { Novo relacionamento antes do } \\
\text { diagnóstico }\end{array}$ & 7 anos & Soronegativo \\
\hline 01 & $\begin{array}{l}\text { Novo relacionamento após o } \\
\text { resultado }\end{array}$ & 4 anos & $\begin{array}{c}\text { Recusa fazer } \\
\text { teste }\end{array}$ \\
\hline 04 & $\begin{array}{l}\text { Novo relacionamento após o } \\
\text { resultado }\end{array}$ & 6 anos & Soropositivo \\
\hline 07 & $\begin{array}{l}\text { Solteira com relacionamentos } \\
\text { eventuais }\end{array}$ & - & - \\
\hline 09 & Sem relacionamento & - & - \\
\hline
\end{tabular}

Em relação à continuidade do relacionamento, a maioria das mulheres afirmam não ter ocorrido mudança. Entretanto, através de seus discursos, pode-se observar ganhos secundários importantes:

"A gente tá mais cúmplice um do outro... se uniu mais por causa dos filhos" (Sujeito. 02).

"Prá mim ele é o mesmo.(...) ele me dá apoio, ele quer que eu me cuide, ele não quer que eu fique doente" (Sujeito 03).

"A mesma coisa, não mudou nada. Pra mim não mudou nada. Pra ele eu acho que mudou uma coisa pouca, que ele fica falando:'eu prejudiquei a sua vida'." (Sujeito 05). 
Estas mulheres encontraram o cuidado e a importância que buscavam no casamento:

“...através do problema da doença, ficou assim, mais unido, ficou mais cúmplice. A gente se uniu mais” (Sujeito 02).

“...porque em nenhum momento, quando ele descobriu, ele desanimou. Sempre me deu força, não disse que ia me abandonar. Não era isso que ia separar a gente. E nunca me abandonou. Sempre que ele me vê triste, me dá força, pergunta o que está acontecendo. Depois que ele descobriu que eu era soropositiva, ficou ainda mais carinhoso, melhor. Melhorou em tudo. A gente ainda tá mais unido" (Sujeito 08).

Ao valorizar o encontro amoroso acima de todas as outras questões, assumir riscos pode converter-se em benefícios importantes ou em reasseguramento identitário, em relação aos quais as preocupações pela saúde podem parecer secundários.

Considerando estes aspectos,levanta-se a questão do risco. De acordo com Knauth (2002), da perspectiva do discurso médico todo risco é visto como negativo, sem considerar que as pessoas podem estar tendo ganhos ao correr determinados riscos, o que tem implicações para a prevenção e tratamento do HIV/Aids e da saúde de forma geral.

No caso dos casais soropositivos, os valores de gênero e os valores sociais como a conjugalidade, maternidade, importância atribuída à família - se sobrepõe à Aids, conforme pode ser observado no discurso do Sujeito 10:

"Muitos casais se separam ao saber uma notícia dessas. Não. Não por isso. Se a gente chegar a separar, não vai ser por esse motivo." 


\section{-Sorologia do Parceiro Atual}

Um aspecto importante a ser considerado trata-se da sorologia para o HIV do parceiro. Neste estudo, a sorologia do parceiro é comprovadamente positiva em dois casos e comprovadamente negativa também em dois casos. Para quatro casais a sorologia do parceiro é desconhecida, sendo que três deles recusam a testagem e um aguarda o resultado. Estes dados podem ser observados voltando ao Quadro 05.

O teste para o HIV pode ter diversos significados, desde o positivo, onde serve de salvo-conduto para o exercício da sexualidade, até o temor da rejeição. Em termos gerais, conforme Lupton et al (1995), podem ser identificados dois tipos de discursos em torno da motivação para a realização do teste anti-HIV: (1) vinculado com sentimentos de vulnerabilidade pessoal e com a necessidade de manter a integralidade corporal; (2) vinculado com a aceitação do indivíduo de seu risco pessoal, junto com outras razões: ter sido exortado por outras pessoas, considerar em termos de negociação sexual, como um controle médico a mais, etc.

Complementando, Kornblit \& Diz (2000a) conclui que, submeter-se ao teste tem simbolizado o compromisso e a fidelidade, como evidencia da integralidade corporal ou como ritual para reduzir a ansiedade gerada por risco percebido como fora de controle. Dentre as pessoas que se recusam a fazer o teste, os significados podem ser: temor vinculado à possibilidade de um resultado positivo, medo da discriminação, medo de perder a parceira, falta de confiança no serviço de saúde, falta de acessibilidade, subestimação do risco e falta de informação.

A estes elementos, de acordo com os relatos das mulheres deste estudo, pode ser incluída a questão de gênero. Os elementos centrais da masculinidade que caracterizam o homem como figura de autoridade, provedor do lar, que não expressa 
suas emoções e sexualmente livre, acabam por levar a uma maior exposição no que se referem à saúde, por se considerarem sempre em condições de enfrentamento e, assim, imunes (Ayres et al, 1999; Vilela, 1997).

A negação do risco da contaminação está presente no discurso do Sujeito 03, ao falar sobre a recusa do parceiro em submeter-se ao teste:

“Ele acredita que ele não tem nada. Ele não quer nem diálogo."

O menosprezo ao risco ao risco também pode ser observado no relato do Sujeito 02:

"Eu converso com ele, eu chamo, tudo, mas ele fala pra mim: ‘uma hora eu vou'. E fica sempre me enrolando. (...) olha o que ele fala:'se você esquentar tanto a cabeça, você vai morrer antes de mim'."

Os fatores econômicos, o tempo e a distância, ou seja , as dificuldades de acesso e os fatores da realidade cotidiana se impõem como restrições ao teste, conforme explica o Sujeito 01 ao justificar os motivos pelos quais o parceiro não faz o teste:

"Eu converso com ele todo dia pra fazer lá no pronto-socorro.To esperando, vamos ver se dá certo. Amanhã, quem sabe, se ele não arrumar emprego a gente vai lá ver."

O temor vinculado a possibilidade de um resultado positivo, no qual combinam o medo da morte, sofrimento, dor, o medo da discriminação ligado principalmente a identidade sexual, faz com que o desconhecimento da sorologia se converta em proteção. 
Além disso, considerando os vínculos conjugais, a realização do teste implica introduzir um elemento conflitivo em uma relação percebida como estável, principalmente ao confirmar a transmissão do vírus para a esposa.. Ao não confrontar cm um resultado positivo, lhes é facultado o "benefício da dúvida".

Ao receber um resultado positivo para o HIV, as mulheres, por não se perceberem em risco, responsabilizam de imediato o parceiro atual. Sendo assim, a sorologia negativa do parceiro é vista com surpresa, conforme o relato do Sujeito 06:

"Eu pensei que tinha pegado dele, fiquei desesperada. Aí ele fez o exame lá no pronto-socorro. Aí deu negativo. Depois ele veio na consulta e deu negativo de novo. Só o meu deu positivo..."

O próprio parceiro, frente ao resultado soropositivo da esposa, assume, de imediato, a responsabilidade:

"Ele até achou que tivesse sido ele, porque antes da gente morar junto ele teve outra mulher. (...) ele foi, fez o exame e deu tudo negativo"(Sujeito 08).

Observa-se que o fato de estar vivendo um relacionamento, implica em desconsiderar as relações passadas de ambos, subestimando os riscos. $\mathrm{Na}$ verdade, ocorre uma negação das possíveis “outras” relações do(a) parceiro(a) atual.

Quando a sorologia para o HIV é confirmada para ambos, é instituído um pacto de silencio sobre um fato consumado:

"A gente sabe um do outro, é como se fosse uma coisa assim... ele não quer muita conversa. E é até bom, eu acho. Porque quando ele começa a falar, ele começa a ficar meio esquisito e eu tenho medo. Ele começa a falar em querer se matar, começa a por coisas na cabeça. Agora, quando a gente não comenta essa história, ele é outra pessoa" (Sujeito 04).

Há uma tendência para a fuga e o segredo. Os casais evitam falar sobre 
questões relacionadas ao medo e à culpa, como uma forma de proteção emocional. Estes aspectos também estão presentes no discurso do Sujeito 05:

"Nós pouco conversa sobre isso. Uma porque eu não gosto de tocar no assunto e ele também não. E eu não gosto de ficar sempre lembrando. Cada vez que lembro disso daí, parece que é uma coisa que remói mais por dentro."

Fica evidenciado o esforço para impor a continuidade da rotina, sem deixarse afetar pela incerteza provocada pela doença.

\section{- Novo Relacionamento Após a Soropositividade}

No grupo estudado, após o conhecimento da soropositividade para o HIV, surgiram três modelos de relacionamento:

- relações conjugais entre pessoas soropositivas (soroconcordantes)

- relações conjugais entre pessoas com sorologias distintas (sorodiscordantes)

- relacionamento eventual

Em estudo sobre o luto das mulheres no contexto da Aids, Oliveira (2000), afirma que após uma situação traumática de perda, o resultado pode ser a capacidade de enfrentar a vida de uma forma mais positiva, buscando outras relações, como também, se houver excesso de complicadores, pode tornar-se uma experiência de muito sofrimento e comprometer a possibilidade de recuperação do sentido pleno da vida.

Para o Sujeito 09, a revelação do status soropositivo representou a ruptura do casamento, a suspensão de investidas afetivas e sexuais, além do surgimento de uma identidade considerada socialmente desviante: 
"De lá pra cá (...) eu não consegui gostar de mais ninguém, sabe? Perdeu a graça. Teve um moço, uma pessoa super legal, que sabe todos os meus problemas e quis até um compromisso, mas eu não quero. Acho que é um problema muito grande com tudo isso que tá acontecendo comigo, então não quero."

O medo da rejeição, a dúvida da revelação da soropositividade ao parceiro e a insegurança quanto a sua reação levam, muitas vezes, a uma fuga de relacionamentos afetivos, como forma de evitar uma possível situação de abandono. É a rejeição por medo da rejeição (Bessa eTerto Jr., 2001), presente também nos relacionamento eventuais, conforme pode ser observado no relato do Suj. 07:

"Eu conheci ele lá no serviço que eu trabalhava. Eu não falei porque... eu fico assim, sabe? E se eu falar pra ele? Tenho tanto medo... Eu fiquei com esse cara, mas não deu certo. Aí ele foi pro canto dele, foi embora, não disse pra onde ia. E eu fiquei no meu."

\section{- Relacionamentos Soroconcordantes}

Comunicar a um novo parceiro sua condição soropositiva para o HIV é um momento sempre difícil, dado à presença do medo da rejeição e da discriminação. De acordo com Maksud (2002), o estabelecimento de vínculos se dá freqüentemente com pessoas que também sejam soropositivas, e muitos consideram ser esse o único tipo de vínculo possível.

Entretanto, o fato de ambos serem portadores, não facilita o momento de confirmar a soropositividade, conforme relata o Sujeito 04:

"Eu já sabia que ele tinha. Só que foi assim, meio esquisito de contar. Você sabe quando ele quer falar as coisas e não fala? Só que eu não queria escutar. Aí ele falou: 'Olha, tem duas coisas que eu quero te contar, a primeira é ruim e a segunda mais ou menos. Então, antes da gente começar a ter uma coisa mais séria já vou te contar...' Aí ele falou assim: 'Oh, eu tenho...' E eu falei: “Ah. Nem fala, deixa por dizer que é melhor.' Aí eu cortei o assunto no meio 
do caminho mesmo. Eu não queria saber. Aí ele falou assim:'Por que você não quer saber?' Aí eu disse: 'Porque do mesmo jeito que você ta, eu também to'. Mas nunca assim, com a palavra direta, Aids. Nunca, nunca, nunca. Aí, do jeito que tava, ficou”.

O secreto é o recurso a que se apela. Embora saibam da existência da Aids, ela é negada no cotidiano. Em estudo com casais soropositivos, Polejack (2002) observou esta falta de compartilhamento da soropositividade. Segundo esta autora, o desgaste do relacionamento, mais do que ao diagnóstico, está vinculado ao conviver com a soropositividade. São as questões relacionadas ao HIV que vão surgindo na conjugalidade e que não tem espaço para existir que trazem dificuldades para o casal.

\section{- Casais Sorodiscordantes}

Observa-se que o risco da Aids entra em uma hierarquia de preocupações em cuja ordem não é prioritária. O desejo de fusão com o parceiro leva à indiferença frente à doença. Apesar deste tipo de vínculo ser mais característico das mulheres frente aos homens, também o marido do Sujeito 01 - soronegativo na época assume esse lugar.

“Eu não queria (...) Eu tinha medo de falar pra ele que eu tinha. Eu não tava preparado pra isso. Falei assim: 'eu não tenho, só que eu não quero mais saber de homem na minha vida'. Mas ele disse: 'Eu não tenho medo. Eu não tenho medo de estar com você,, de pegar, porque eu gosto de você."

Através desse discurso observa-se que o amor, o desejo de estar junto é a meta principal, de tal modo que o risco do HIV não pode ocupar o centro das preocupações. Segundo Korniblit \& Diz (2000b), a busca pela intimidade total e o desejo de demonstrar o caráter absoluto do amor que se tem pelo parceiro são 
motivadores poderosos que afastam a possibilidade de qualquer outro tipo de racionalidade, inclusive, da prevenção.

Estes aspectos podem ser observados no relato do Sujeito 06, que vive uma relação sorodiscordante há 3 anos:

"Eu queria largar dele, não queria mais ficar com ele. Principalmente que ele não gosta muito de camisinha, ele não quer nem saber, quer ter relação de qualquer jeito. E eu falava que ia ficar muito arriscado, vai ficar perigoso, vai acabar pegando. (...) eu queria largar dele. Aí ele não quis, ele quis continuar, quis ficar comigo..."

No caso da relação sorodiscordante, além da possibilidade de infecção entre os parceiros, há uma questão de desvalorização simbólica da relação entre pessoas marcadas socialmente como diferentes. Estudos demonstram que as imagens associadas a uma relação discordante, para pessoas soronegativas, são as de perda, doença, angústia e solidariedade. A relação sorodiscordante dá visibilidade ao tabu da soropositividade (Passarelli \& Spink, 1998) e evidencia como o soropositivo se enxerga nessa sociedade que coloca, por várias razões, os indivíduos numa posição estigmatizada (Parker \& Aggliton, 2001; Goffman, 1988).

Outro fator no tocante á sorodiscordância, se refere ao fato de que os casais sorodiscordantes são alvo de preconceito aumentado, que vai desde a esfera familiar até a médica (Knauth, 2002). Este preconceito está inserido em um contexto mais amplo, que se refere à dificuldade que se tem em aceitar a união entre diferentes, no caso a união entre alguém que é saudável e alguém que tem uma doença.

A união da diferença remete novamente à questão do risco. E, neste contexto, o risco é minorado frente à outros riscos, que tanto pessoas soronegativas 
ou não, estão sujeitas: o risco de ficar sozinha, de não ter filhos, de não ter um companheiro, não ter amor, não ter com quem compartilhar a sua vida.

São questões que se sobrepõem à Aids, estando circunscritas em torno do valor atribuído a conjugalidade. Concebem a família como um meio de alcançar a felicidade, através de um modelo de fusão entre os cônjuges e de amor aos filhos.

\section{-Representações sobre o Amor}

De um modo geral, as entrevistadas se afastam da construção pós-moderna de amor, baseada na independência e na autonomia e respondem ao modelo de amor moderno, edificado sobre o ideal do amor romântico, da fusão entre os membros do casal.

O Sujeito 08 coloca em seu discurso uma relação de fusão com base no desejo de compartilhar todos os aspectos da vida:

"Amar pra mim, eu acho que é assim, a pessoa ficar sempre perto da pessoa, não só no momento que é melhor, mas no pior, que ninguém fica. Todo mundo abandona. Mas eu acho que uma pessoa que ama de verdade faz qualquer coisa pelo outro."

Este discurso compartilha as características com o amor romântico, na qual se idealiza a pessoa amada e se vincula com a responsabilidade mútua de projetar uma história compartilhada a longo prazo.

As questões de gênero são evidenciadas nos discursos sobre amor, demonstrando a influência ainda exercida pelos discursos normativos dos Séculos XVIII e XIX no que diz respeito à conduta e aos sentimentos.

Assim, para o Sujeito 09, o amor é cuidado, proteção e renúncia: 
"Amar alguém, pelo menos no meu ditado, é, mesmo passando por dificuldades, nunca querer que a pessoa sofra também, não passar a dificuldade para a outra pessoa. Acho que isso é amor. E também, amar alguém é, como as vezes as pessoas me criticam porque meus filhos ficam internados (casa de assistência à crianças com Aids), falam que eu não tenho amor por eles. Eu acho que o meu melhor amor pros meus filhos é ver eles tendo tratamento, do que comigo."

Para o Sujeito 04, o amor é entrega, dedicação:

"Eu acho que o amor, entre um homem e uma mulher, seria assim, não comentar muito certos problemas, um fazer tudo para ajudar o outro, gostar bastante da pessoa até fazer tudo para dar certo, nunca pra dar errado."

O Sujeito 06 condiciona o amor à confiança. Amar supõe confiar no parceiro, geralmente baseado em critérios de conhecimento de características pessoais, acreditando na estabilidade do relacionamento.

"Amor, pra mim, é quando a gente começa a pegar confiança numa pessoa e se apega."

É feito referência também ao amor enquanto sensação, magia, sentimento incontrolável, arrebatador:

"O amor é inexplicável. Não tem como explicar. Acho que o amor a gente só tem uma vez na vida” (Sujeito 10).

"É uma coisa que vem lá de dentro. O amor é uma coisa bem boa, bem gostosa. Quando você ama de verdade, é muito bom." (Sujeito 05)

A valorização do encontro amoroso acima de todas as outras coisas pode ser observado no relato do Sujeito 03:

"Amor, eu acho que é o sentido de tudo. Se você não tem amor, você não tem compreensão, você não tem nada." 
Analisando estes discursos em conjunto com as histórias de vida destas mulheres, observa-se o quanto elas buscam no encontro amoroso, vencer a angústia e incerteza acerca de sua própria identidade. Querem ser amadas e, nesta intenção, abdicam de si à favor do ideal de amor e fusão.

Para Korniblit \& Diz (2000b), a busca amorosa como parte da busca identitária, em suas facetas de inserção social e de reconhecimento afetivo, são aspectos que integram os processos de vulnerabilidade. Nestes processos, o imaginário de doação total de si mesma é a contrapartida da ilusão de receber do outro também um tributo tal que seja capaz de afastar toda a incerteza acerca da qualidade de ser querido.

\section{- As "Lógicas" da Prevenção}

Em uma investigação desenvolvida por Peto et al (1997), citada por Kornblit \& Diz (2000c), são descritas estratégias que as pessoas colocam em prática com seus parceiros para encarar o risco de transmissão do HIV, que são compreendidas entre dois pólos: a confiança cega e a gestão racional do risco.

Postulam que cada um dos tipos de proteção adotados pelos casais tem sua própria lógica de ação que são identificados e se vinculam com determinadas situações da vida das pessoas. Assim, a afetividade pode ser prioritária frente ao cuidado para as pessoas que se sentem sós e querem carinho.

De acordo com Kornblit \& Diz (2000c), as lógicas adotadas pelas pessoas que não previnem a infecção pelo HIV revelam dois tipos de cenários de relações: 
O primeiro se caracteriza por um sistema íntimo forte, em que a devoção ao outro ou a idéia de casal são características prioritárias. O objetivo é a fusão com o outro, ainda que ela seja fugaz. Nesta lógica encontram-se características do amor romântico.

O segundo cenário, constituído pelas lógicas adotadas pelos que se cuidam, se caracteriza por um sistema íntimo fraco, que coexiste em pé de igualdade com outros interesses sociais e outros valores.

Desta forma, as mudanças comportamentais têm lugar segundo qual seja o sistema social íntimo em que se dá o relacionamento. É este sistema que regula a entrada ou não de estímulos referidos à necessidade de proteção frente ao risco.

$\mathrm{Na}$ medida em que o sistema social íntimo se define como amoroso, mais que como sexual, se admitirá o risco, conforme confirma o relato do Sujeito 10:

“...se eu não tivesse gostado desse rapaz, se eu tivesse ficado quieta pra lá, ou tivesse ficado com alguém que não gostasse, eu não teria transado sem camisinha. Se eu não tivesse gostado, nós não tinha, assim, se contaminado..."

O principal meio de transmissão é o sexual, por isso grande parte dos esforços de prevenção centra-se sobre os estímulos ao uso de barreiras nas relações sexuais. Existe, entretanto, um descompasso entre a realidade dos Sujeitos e as diretrizes de prevenção. A importância do referencial do casal na conformação da identidade de ser e sentir-se pessoa tem sido demonstrado em vários estudos. E nesta questão, a recomendação do sexo seguro em toda e qualquer relação sexual contém um paradoxo (Saldanha, 1998; Maksud, 2002; Heilborn \& Gouveia, 1999). 
Os avanços na abordagem pelos adolescentes de temas relacionados com a sexualidade são evidentes (Muza \& Costa, 2002). Novos modos de relacionamentos surgiram provocando modificações importantes nas relações de gênero, mas, ainda assim, é uma relação que continua assimétrica e bastante desfavorável. A proporção de gravidez entre as adolescentes é cada vez maior entre adolescentes e adultos jovens, evidenciando que o sexo desprotegido tem ocorrido mais precocemente (Villela, 2002).

De acordo com pesquisa de Kornblit \& Diz (2000b), as pessoas que iniciaram sua vida sexual na "era da Aids" tem incorporado em maior grau o preservativo como prática regular em suas relações sexuais. Entretanto, abandonam o uso sistemático quando o relacionamento passa a ser estável, momento em que passam às pílulas anticoncepcionais, desconsiderando o risco de infecção pelo HIV.

A convivência com quem se ama e a confiança - base das relações amorosas - no parceiro, faz com que a prevenção se torne desnecessária. Mais do que isso, não há espaço para qualquer barreira que se interponha entre o casal. Há uma negação do risco.

No relato do Sujeito 10, pode ser observado que, mais do que a ausência de poder na negociação do uso do preservativo, há uma desconsideração do risco baseado na confiança e estabilidade da relação:

"Não é que você não pede. Eu comecei com a camisinha, só que você vai aumentando os encontros, começa a ficar mais freqüente, você vai mudando, até que passei a viver junto. Aí, você começa a mudar as coisas.Não que você não exige, mas começa a mudar. Você começa a conviver, isto e aquilo, e vamos arrumar um filho. Ninguém pensa, ninguém faz um teste primeiro. Ninguém. Não existe.” 
O Sujeito 05 confirma, com os mesmos argumentos:

"No tempo de namoro, sim, usava. Mas depois que fomos viver juntos deixamos de usar. Eu botei confiança nele e ele também. Eu não imaginava acontecer alguma coisa. Simplesmente o que podia acontecer era eu engravidar. E nós queria, né?”

Para ambos, o risco estava colocado na gravidez e não na Aids, a partir da lógica da confiança e da ilusão da afinidade total com o parceiro. Como a infidelidade não pode entrar no sistema íntimo, aparta-se da idéia de risco possível, inclusive desconsiderando-o como proveniente de experiências passadas.

Apesar de estar presente no discurso das mulheres a idéia de que os homens traem, isto não se constitui, entretanto, numa representação que se impõe. Sua importância é diluída em favor de todas as outras coisas construídas na vida conjugal e obtidas com ela, deixando claro que há uma escala hierárquica das representações da vida conjugal, onde a fidelidade é algo muito importante.

Por outro lado, de acordo com pesquisa de Silva (2002), não se faz referencia à traição da esposa. A fidelidade feminina é algo "natural", assim como é "natural" o comportamento do homem propenso à traição, ou seja, há uma ausência de referências ao comportamento infiel da mulher e, portanto, a sugestão de que as relações conjugais não oferecem risco.

O ideal de espontaneidade, o mito da naturalidade na relação, a família como meta de felicidade, unida por laços de amor e proteção, numa imagem correspondente ao modelo burguês do século XIX, exige a abolição de toda barreira entre os membros do casal, constituindo em aspectos contrários à conduta de proteção sexual. 
Sendo assim, concordando com Korniblit \& Diz (2000c), antes da presença efetiva da soropositividade, o uso de preservativo é considerado legítimo em três tipos de vínculo amoroso:

A - nos primeiros encontros sexuais, quando não se conhece bem o parceiro, até que se instaure a confiança;

B - nos encontros sexuais ocasionais, onde o risco é percebido;

C - nas relações com parceiros onde não haja grande envolvimento, quando, então, é possível manter a lógica racional.

Após o diagnóstico da soropositividade, o Sujeito 10 relata o uso consistente do preservativo durante as relações sexuais com o marido:

"Ele não gostava. Usa porque a gente conversou muito sobre isso e sabe que é melhor para os dois, nem só pra mim, nem só pra ele. Então a gente usa, normal."

Para os Sujeitos 02 e 03, apesar da inconsistência no uso do preservativo, a negociação com o parceiro tem sido efetiva:

"Hoje eu tenho que conscientizar bem ele. Por meio de conversas eu falo pra ele:'Põe a camisinha. Você tem o vírus. Eu tenho o vírus. O problema dobra.'Então, hoje ele já fala: 'Nega, pega a camisinha.'(...) Mas tem vezes que falha em usar e também falha porque a camisinha também pode furar..." (Sujeito 02)

“Antes não. Agora eu uso. Ele aceita bem.”(Sujeito 03)

Conforme Kornblit \& Diz (2000b), a dinâmica da relação e a adoção de condutas preventivas são resultado de um processo de negociação entre os membros do casal ao longo do tempo. Tal processo se desenvolve levando em conta as linhas de poder com relação aos recursos disponíveis para ambos os membros. 
Tais recursos, segundo Bordieu (apud Kornblit \& Diz, 2000b), podem se classificar em sociais (redes sociais de apoio), econômicos (relação de dependência de um membro em relação ao outro), culturais (adquiridas através da educação e experiências) e simbólicas (habilidades para explorar os três recursos precedentes).

Ainda segundo este autor, as estratégias de proteção que são negociadas abertamente, como a comunicação direta à respeito de temas sexuais, parecem mais exceção do que a norma.

Com relação aos casais sorodiscordantes, alguns estudos têm demonstrado que a descoberta do diagnóstico soropositivo pouco induz à comportamentos preventivos no parceiro soronegativo. Isto expõe a dificuldade em integrar as modificações de comportamento na vida sexual cotidiana, ainda que exista o risco do HIV.

A manutenção rigorosa e sistemática de um comportamento protegido/protetor é muito difícil (Korniblit \& Diz, 2000c). Especialmente quando se encontram presentes elementos característicos do amor romântico, como no relato do Sujeito 01:

"A gente começou usando preservativo. Aí, aconteceu de um dia furar e daí, de lá pra cá... Ele falou:'Se eu tiver que pegar, eu peguei naquela noite'... (...) Ele falou:'...não importa, eu vou ficar com você pro resto da minha vida. Agora vai ser eu e você. Você olha por mim e eu por você'. E estamos aí, até hoje. Eu falo pra ele que não queria que ele pegasse, eu queria que ele ficasse comigo, mas usando o preservativo. (...)ele fala:'não precisa porque eu gosto de você e vou ficar com você o resto da minha vida. Se eu morrer de Aids de hoje pra manhã, eu vou morrer feliz’. (...) Eu confio muito nele. De quem ele gosta é eu e vai ser sempre eu. E eu também." 
Este relato faz referencia ao amor romântico, ao amor paixão, denotando uma urgência que o coloca à parte das rotinas cotidianas. Embora exista a percepção do risco da Aids, a incondicionalidade, a entrega total é a característica mais saliente.

Outra lógica subjaz deste relato, a fatalidade, onde a Aids é colocada como inevitável e, portanto, a prevenção é inútil.

Neste caso, a entrega por amor, característica da subjetividade feminina, se apresenta no pólo masculino do casal, e afasta qualquer outra consideração que leve a outras preocupações, como a saúde.

Concluindo, os discursos das mulheres soropositivas para o HIV, infectadas em relacionamentos estáveis, demonstram a existência de outras racionalidades, que provêm de processos interativos e são influenciadas por valores e normas.

Nestes casos, a persistência de comportamentos de risco não é produto da falta de percepção de risco ou de informação, mas de outros códigos provenientes de contextos relacionais em que se desenvolve sua vida.

Evidencia-se, principalmente, que vários fins podem estar presentes em um mesmo momento, que existem prioridades que pode não ser a saúde, que tem diversos modos de perceber o risco e que este pode ser definido de diversas maneiras e, finalmente, que as normas ideais podem colidir com as normas práticas.

\section{C - A Prática em Saúde no Discurso da Mulher Soropositiva}

Saúde e doença são metáforas privilegiadas para explicar a sociedade, pois engendram atitudes, comportamentos e revelam as concepções de mundo. Além 
disso, expressam opiniões sobre as instituições e sobre toda a organização social em seus substratos econômico-político e social. Sendo assim, "doenças como a Aids funcionam como um desafio à ciência, ao progresso, colocando em jogo o sentido da corporação médica e sua imagem salvadora na impotência frente à morte" (Minayo, 1998 p.183).

As mulheres soropositivas para HIV, ao contarem a sua história de vida, relatam também a realidade vivida enquanto usuárias sistemáticas de serviços de saúde, o que consiste um lócus privilegiado para sua avaliação.

Ainda que não satisfaça às necessidades da população, é a ordem médica que tem poder e é reconhecida e legitimada por todos os profissionais e usuários, extremamente influenciados pelas crenças e valores vigentes. Entretanto, de uma forma geral, observa-se que, apesar de assimilarem as concepções clínicas e agirem também a partir das regras estabelecidas pelos especialistas, as mulheres soropositivas têm uma visão mais abrangente do fenômeno saúde, que comporta uma concepção de homem como corpo/alma, matéria/espírito e inclui relações afetivas e condições de vida e trabalho na definição de sua situação. Assim, apesar de reconhecerem o poder médico e subordinarem-se à medicalização, elas possuem uma visão crítica a partir da experiência, tanto dos profissionais e suas técnicas, como do sistema de assistência em saúde do qual fazem uso. Por isso, reinterpretam o esquema racionalizado, usam-no de acordo com os seus interesses imediatos e concepções particulares e não legitimando o saber médico, configurando o que Minayo (1998) denomina de "código de resistência" (p.195). 


\section{-Relação Profissional de Saúde - Paciente - Serviço de Saúde}

De acordo com Ballint (1984), citado por Nardi (1999), a relação médicopaciente, que neste trabalho é ampliada para profissional de saúde - paciente, tem uma função tão ou mais importante que o medicamento utilizado para o tratamento da doença. Segundo este autor, com o isolamento urbano das sociedades industriais, o médico torna-se, muitas vezes, o único recurso para o qual o paciente consegue dirigir suas queixas. Portanto, a maneira como este escuta a sua queixa, independente de uma origem patológica clássica ou de origem psicossomática, vai implicar no seguimento ou não do tratamento. Ainda que o médico não apresente solução para o problema apresentado, o principal gerador de sofrimento se dá quando o paciente percebe que o médico desvaloriza sua queixa e não se interessa em compreendê-lo, ignorando sua dor.

Numa sociedade onde, as relações sociais se realizam na diferenciação de classes, a relação entre profissionais de saúde e pacientes também se dá em função, principalmente, da classe social do doente. E é através de relações e instituições legitimadoras de seus atos e discursos, dentro de um esquema corporativo, que o profissional de saúde reproduz de forma contraditória as concepções sobre saúde/doença (Boltanski, 1989; Minayo, 1998).

Ao pesquisar sobre a avaliação moral que a clientela sofre pelos profissionais de saúde, desde a recepção até o atendimento médico em serviços de emergência de hospitais, Roth (1972) conclui que esta avaliação é decorrente da aplicação de conceitos comuns da sociedade como um todo, associados aos conceitos da equipe à respeito do papel apropriado de trabalho. Enfatiza, principalmente, a avaliação moral como possuidora de efeito direto sobre a diagnose do médico e as 
recomendações de tratamento. Constatou, dentre os fatores que afetam o atendimento, aspectos como: a idade (o jovem é considerado mais valioso que o idoso); a diferença de tratamento a partir do status social (englobando aspectos do vestuário, higiene pessoal, escolaridade, maneira de falar, etnia, se dependentes do Estado, etc.); e, ainda, os conceitos da equipe à respeito das funções que acreditam ser apropriadas (por exemplo, se é caso para a "emergência" ou para ambulatório especializado).

Foi observado que, na relação entre profissional de saúde e paciente, a percepção que o médico faz do paciente, esta é anterior ao contato pessoal, decorrente das anotações deixadas no prontuário médico, no qual estão assinalados seus antecedentes, ou pela carta de encaminhamento que o acompanha de setor a setor e que fornece informações selecionadas que traçam uma imagem social, em função da qual o profissional definirá sua estratégia frente ao paciente.

Em consequiência, o discurso do paciente sobre o médico não deixa de ser, segundo Boltanski (1989), um discurso hesitante, conforme pode ser observado na fala do Sujeito 02:

“...parece que a gente nem tem o problema. Tratam a gente, quer dizer, às vezes a gente precisa lembrar... (...)pô, será que eles sabem do meu problema? (...) ...você tem que ficar lembrando os médicos e pedir, pelo amor de Deus, me ajuda”.

Ainda de acordo com este autor, este fato se deve à ausência de um critério objetivo que lhes permita apreciar as qualidades profissionais do médico. Diferente das classes mais favorecidas, que escolhem os profissionais baseados em títulos e reputação, nas classes trabalhadoras esta "escolha" é feita ao acaso, em função dos critérios dos Serviços de Saúde, onde nem sempre é o mesmo profissional quem faz 
o seguimento do tratamento. Portanto, por não possuírem os critérios específicos que lhes permitam medir a competência do médico, a avaliação se dá "em função de critérios difusos, usados cotidianamente na apreciação de outrem: a amabilidade, a boa vontade e a complacência” (p.38). Tal situação foi constatada no discurso das mulheres entrevistadas. O fato de o médico ser amável e conversar foi um critério de avaliação de competência, como pode ser exemplificado no discurso a seguir:

"O médico que eu faço a minha consulta, ele é muito bom. Ele é muito atencioso, conversa bastante. Qualquer coisa que eu não sei, que eu tenha dúvida, eu pergunto e ele sempre me responde." (Sujeito 03).

Entretanto, é importante discutir como as explicações são dadas, se pelo simples repasse de conteúdos (visto como instrução ou orientação informativa, de caráter normativo) ou pela valorização da interação profissional/usuários, incentivando a troca de conhecimentos e a verbalização de dúvidas e temores. Conforme ressaltado por Filgueiras e Deslandes (1999), essa troca só é possível com o reconhecimento de que os usuários detêm conhecimento prévio, baseados nas experiências do cotidiano e do senso comum, que embora não tenha caráter científico, é orientador do comportamento destes indivíduos. Portanto, ignorar tais concepções é perder a chance de relativizá-las.

Alguns estudos realizados pelo Programa de Atendimento Psicossocial à Aids - PAPSI, demonstram que além de se estender às questões da organização da práxis, a formação dos profissionais deve ser reorientada para a capacitação do profissional de saúde no sentido de poder sistematizar e aproveitar a aprendizagem informal, acumulada pela experiência no trato com o paciente. 
Para tanto tem realizado grupos de pacientes objetivando, além do suporte, uma fonte de recursos com relação ao levantamento de informações sobre as necessidades no atendimento. Além disso, grupos com profissionais de várias especialidades, engajados no atendimento à Aids, visando a obtenção de alguns elementos necessários para realizar a síntese entre as duas perspectivas que devem prevalecer no atendimento a pessoas com Aids: a visão compreensiva do profissional sobre a perspectiva do paciente e o envolvimento deste com as condições técnicas do atendimento.

Neste sentido, Figueiredo (2000a) acrescenta:

“...além da recuperação da prática informal, o outro lado do atendimento deve também ser reconstituído e a opinião dos pacientes/usuários dos serviços retoma a sua importância para a concepção do trabalho, enquanto todo. 'A visão do outro envolvido' no atendimento clínico da Aids representa a 'porta de entrada' para um universo de representações que ultrapassam os limites da doença e que, pela sua natureza, esgotam os recursos da competência técnica e dos procedimentos clínicos voltados para o tratamento das infecções oportunistas” (pág. 02)

Em pesquisa com profissionais de saúde em centros de referência para DST/Aids, Silva et al (2002), as características clínicas e o tratamento da doença foram citados como temas recorrentes de diversos treinamentos e capacitações, sendo escassos ou inexistentes, contudo, os espaços para a discussão de outros temas. Entretanto, e talvez mais importante, observou-se que o movimento de apreensão da Aids não se limitava a esse espaço formal, mas acontecia a partir de reuniões e discussões informais entre os profissionais, de acordo com as necessidades percebidas no cotidiano de suas práticas. Essa troca informal de experiência foi o momento em que estes profissionais puderam se apossar das dimensões interdisciplinares das necessidades de assistência às pessoas com Aids. 
Foi observado, ao longo do período de coleta de dados, um grande comprometimento dos profissionais com seu trabalho e o compromisso que têm com o paciente. No entanto, tal postura não pode ser confundida com uma atitude de verdadeira escuta, com a priorização das informações do paciente com base na sua vivência. Em geral, além do tratamento diferenciado, a utilização pelo profissional de um vocabulário especializado e as explicações dadas ao paciente, variam de acordo com sua classe social. Não são dadas explicações efetivas senão àqueles que julgam capazes de entender. Geralmente as explicações vêem em forma de ordens imperativas, ao invés de um aconselhamento em duplo fluxo de linguagem.

A falta de informação sobre a doença e tratamento leva o paciente a construir com seus próprios meios, um discurso com materiais fragmentados e palavras mal-entendida:

“...to tomando dorim, parece. Eu não sei, acho que é isso, esse nome do remédio mesmo. É uma cápsula branca” (Sujeito 07 referindo-se a um dos antiretrovirais).

É comum que, principalmente no primeiro contato profissional/paciente, o preenchimento de fichas de anamnese seja visto como meta a ser cumprida, transformando a atitude de escuta em coleta de dados sobre o paciente, ao invés de priorizar este momento na personalização das informações com base nas vivências do paciente. A esse respeito Filgueiras e Deslandes (1999) consideram que este roteiro precisa ser visto como base da relação que será construído a dois na relação profissional-usuário diante das reais demandas deste.

No entanto, mesmo quando os sentimentos são colocados pelo paciente, não é propiciado um espaço para que se possa falar, refletir e explorar os significados de 
tal situação. Isso acontece freqüentemente durante a entrega de um diagnóstico soropositivo ou ainda na constatação de gravidez.

A atitude autoritária do profissional de saúde e sua reserva em fornecer informações que permitiriam dar um sentido aos atos e prescrições, ou seja, as razões e o conhecimento que fundamentam e dão sentido às regras, ficam sempre implícitos (Boltanski, 1989). No caso de perceber alguma resistência do paciente em seguir as prescrições, não é através da explicação sobre o princípio de eficácia do medicamento prescrito ou da regra enunciada que ele procura eliminar as objeções, mas através do enunciado de sanções que decorrerão automaticamente da desobediência, ou seja, pela enumeração das consequiências da transgressão da norma.

Este fato pode ser observado no relato do Sujeito 04, quando, após ter recebido o diagnóstico da causa da morte do parceiro, é solicitada a fazer o teste antiHIV:

... o médico falou: ó, você faz, mas com certeza vai dar que sim. Eu já vou logo te avisando. Aí, claro, com certeza eu ia ter, né? Eu já sabia, né?

Assim, o doente faz uma seleção do discurso médico, retendo apenas os termos que reconhece, mesmo ignorando o seu significado científico, na tentativa de reconstruir um discurso coerente:

“...às vezes depende do que é melhor pensar, do que lembrar daquilo do que ele falou...” (Sujeito 10).

Ou ainda, atribui sentido aos termos, reinterpretando-os de acordo com a sua vontade: 
“...eles me trataram como se eu fosse uma mãe normal. Então, eu fiquei naquela, pô, será que eles sabem do meu problema? Porque facilitaria pra mim não ter mais...” (Sujeito 02).

Os problemas de entendimento da mensagem não se limitam à falta de clareza da linguagem, visto que também dizem respeito ao não compartilhamento dos significados culturais vinculados às vivências do paciente. O conteúdo a ser comunicado precisa ser competente, do ponto de vista de uma compreensão mediada pelos valores e vivências do grupo a que se destina. A comunicação diz respeito, necessariamente, à possibilidade do diálogo, confronto e reciprocidade (Filgueiras e Deslandes, 1999).

A barreira mais visível entre o médico e o paciente, de acordo com Minayo (1998), se dá através de um código de linguagem fechado e específico que, em primeiro lugar, se atém ao contorno biológico e individual do doente, explicando o fenômeno saúde/doença como o bom funcionamento dos órgãos e como responsabilidade individual, separando o sujeito do seu meio, de suas experiências, de sua classe e dos condicionantes de sua situação. Em segundo lugar, reduz o conceito de doença à especificidade de um determinado órgão, objeto de um saber fragmentado. Em terceiro lugar, a práxis médica chega a prescindir da realidade mais imediata e sensível que é o corpo e seus sintomas, voltando-se para as mensagens infracorporais fornecidas pelos equipamentos laboratoriais.

Na verdade, conforme Camargo Jr. (1994), a Aids é

"duplamente desconfortável para a maioria dos médicos, em primeiro lugar porque os coloca frente a questões tabus, como a sexualidade tida como desviante ou o uso ilícito de drogas, questões para os quais não se encontrava preparado (...) Em segundo lugar, a informação sobre o modo de contágio depende técnica e exclusivamente da informação dos pacientes...” (p.47). 
A Aids trouxe consigo a necessidade de reformulação da estrutura de autoridade médica, impondo a necessidade de escutar o paciente como um todo e não apenas examinar o órgão doente. Trouxe também a necessidade de lidar com as questões afetivas e sociais, antes relegada aos segundo plano. E, assim, tornou visível o despreparo e a desorientação que envolve os profissionais de saúde no trato psicossocial da doença. Além disso, como doença recente, muitos profissionais não aprenderam sobre Aids na faculdade, tendo que fazê-lo na prática diária de seu atendimento.

Em estudo realizado por Malbengier et al (2000) visando avaliar as dificuldades de médicos infectologistas diante de pacientes soropositivos ao HIV, uma das questões abordadas diz respeito à dificuldade em falar sobre a morte, mesmo quando abordado pelo paciente, salientando-se que o importante não é a morte em si, mas como se lida com ela no contexto da epidemia da Aids. "Sabe-se que no curso de medicina não há um treinamento para abordar a questão morte. Ensina-se a combate-la ou retarda-la, mas não discuti-la” (pág. 90).

Além do fato da maioria não se sentir instrumentalizado para abordar o assunto, o autor analisa que a Aids, "com seu prognóstico de morte devolveu ao doente a posse do conhecimento da sua morte. Isto não é mais algo que pode ou não ser informado ao paciente, dependendo do médico... (p. 90). Ela remete o profissional às suas próprias questões sobre a vida, sua impotência diante da morte, sua formação e identidade profissionais.

A dificuldade e o despreparo dos profissionais de saúde são captados pelas pacientes, conforme pode ser observado no discurso seguinte: 
"Os médicos estão estudando, mas entender, entender mesmo... nem eles sabem" (Sujeito 10).

A quase totalidade dos médicos entrevistados por Malbengier (2000.) fala do desgaste do atendimento ao paciente soropositivo em relação aos outros pacientes. Ressaltam como causa, principalmente, o fato das consultas não se limitarem a discussão de exames e medicações, ainda que suas posturas sejam mais de fonte de informações do que para possível discussão. A irritabilidade também foi relatada diante da ineficiência, precariedade e desorganização dos serviços públicos diante de uma doença de provas diagnósticas e tratamentos complexos. Estes fatores, somados a falta de preparo para lidar com estas questões e diferenças, tornam o atendimento extremamente desgastante, podendo interferir no tratamento.

Este conflito é exemplificado na fala de Gauderer (1981):

"Somos envolvidos nos aspectos psicossociais e emocionais desse paciente $e$ dessa família. Temos um papel de coordenar o tratamento físico e emocional e quanto maior o nosso envolvimento na parte psíquica, maior a nossa eficiência e melhor a resposta clínica. Com o nosso diagnóstico destruímos sonhos e esperanças de uma (...) família. ... é extremamente difícil para nós lidarmos com o luto e o sofrimento desta família (...). Este luto nos coloca em contato com a nossa própria morte e sofrimento (...) é uma ameaça a nossa onipotência” (pág. 48).

De acordo com Figueiredo (2001), muitos profissionais, diante da impotência frente a irreversibilidade do quadro da Aids têm apontado nos próprios clientes a causa de seu fracasso. Pressões psicológicas, decorrentes da interação com o paciente se contrapõem a pressões profissionais determinadas pelas obrigações e auto-realização no trabalho. E, diante deste quadro, que determina um atendimento caracterizado pela ênfase na competência técnica, o paciente sofre a ausência de abordagens que se estendem ao atendimento de suas necessidades psicossociais. 


\section{- Diagnóstico Soropositivo}

Figueiredo e Ribeiro (1996), em estudo sobre o ponto de vista do paciente com Aids à respeito do atendimento clínico recebido, ressaltam que, dada a complexidade do momento da confirmação do diagnóstico, a forma com que se dá é determinante para suas condutas futuras, envolvendo o convívio com a doença, a adesão ao tratamento e, principalmente as representações de si enquanto portador. $\mathrm{O}$ papel do profissional é determinante, devendo este estar preparado para lidar com as questões afetivas que envolvem o trato psicossocial da doença, além de ser continente às necessidades de cada pessoa.

Entretanto, a necessidade de ter que lidar com aspectos que não estão previstos nas "rotinas diagnósticas", coloca o profissional frente a abordagem de temas para os quais sua formação não o prepara, deixando-lhe a opção de abordá-lo segundo seu padrão moral particular. Esta falta de preparo no lidar com as questões de ordem afetiva pode ser observado no relato do Sujeito 07, ao receber o diagnóstico soropositivo:

"Eu fiquei chocada com ela (médica). Ela não devia ter dito assim, na lata. Eu acho que ela deveria chegar, conversar, explicar tudo direitinho... Por exemplo, o enfermeiro... médico... acho que era estudante, ficou doidinho ali do meu lado. 'Não fica assim, você não está doente, não fica assim', ele falou pra mim. Ela falou pra mim e saiu e ele entrou. Ele não sabia o que falava pra mim, o que fazer".

Os profissionais com formação fisiopatológica, por acreditarem que a escuta e o apoio não seriam seu papel ou por não se sentirem aptos para incorporar essas práticas, fazem encaminhamentos aos psicólogos ou assistentes sociais, sem 
perceber que a escuta, o acolhimento e a terapêutica medicamentosa são indissociáveis.

Estes fatos têm origem no modo com que o trabalho em saúde tem sido organizado e sua determinação sobre a formação do profissional. Principalmente pela forma fragmentária com que a doença é encarada, conseqüência da subdivisão do conhecimento em especialidades, cujos territórios são estreitamente demarcados, fazendo com que o profissional de saúde veja o paciente sob a ótica de sua especialidade, tratando somente "parte" da pessoa (Figueiredo, 2000b; Figueiredo \& Ribeiro, 1996). Como se existisse corpo ou demanda referida ao corpo, "que já não seja imediatamente revestido de significados sociais, psicológicos e emocionais" (Mendes-Gonçalves, 1994).

Transparecem, nos relatos, as dificuldades do médico que, diante de um resultado positivo para o HIV, recorre a outros profissionais para que comuniquem o resultado à pessoa que fez o exame:

O médico (do posto de saúde) falou assim: eu não tenho certeza porque isso aqui foi passado por telefone, não tenho certeza. Então você vai pra lá (serviço de saúde especializado) pra fazer um teste de novo. Aí, marcou pra mim, eu vim, fiz um teste rápido, na hora já saiu o resultado. (...) Aí eu fiquei, na hora, eu fiquei sabendo. Já entrei em desespero (Sujeito 05).

A subdivisão do conhecimento em especialidades, cujos territórios são estreitamente demarcados, fazendo com que o profissional de saúde veja o paciente sob a ótica da sua especialidade, exclui da prática cotidiana categorias essenciais para que haja a formação do vínculo profissional-paciente. Neste sentido, Figueiredo (1996) ressalta que "o profissional se preocupa muito mais com o diagnóstico do que com a terapêutica e seu discurso, ao invés de provocar uma aproximação, acaba por 
ser uma forma eficiente de manter o paciente alienado de sua própria situação, já que não se estabelece um nível adequado de comunicação” (p. 05).

A ambivalência da responsabilidade em função da competência técnica também pode ser observado no relato do Sujeito 10, que percebe a dificuldade do profissional como falta de conhecimento:

Eu já tava no final da gravidez, já não tava fazendo pré-natal no posto, tava fazendo na ... (maternidade). Aí, o posto me chamou de novo, que havia tido um problema no meu sangue. De lá vim direto no posto, mas não consegui saber o resultado porque o médico... acho que ele não entendia bem do exame. Ele pediu que a gente voltasse no outro dia que ele ia conversar com alguém que entendesse para dar o resultado. Fomos pra casa a cabeça à mil... No outro dia a gente voltou lá, eu voltei com o meu marido de novo e ele deu o resultado...

No caso do Sujeito 08, foi necessária uma postura ativa de busca do diagnóstico pelo paciente:

O médico não me falou nada. Tinha uma moça no meu quarto e aí, um dia, o médico foi lá e falou pra ela que ela era. Eu não sabia de nada, mas achei estranho. Aí, eu cheguei lá e falei: olha, se eu tiver alguma coisa, me fala. Porque se ela era HIV, por que eu tava lá também? Aí foi quando ele me explicou que tava desconfiado. Mas ele não falou pra mim, chamou meu marido e falou pra ele. Aí meu marido me falou...

Perde-se assim, a possibilidade de preparação psicológica, desde o primeiro contato com o profissional ou o serviço de saúde até a recepção do diagnóstico, considerando não somente o momento da devolutiva, mas também os antecedentes e conseqüência deste, considerando esse processo como um todo, o que, de acordo com Figueiredo \& Ribeiro (1996), é fundamental para o acompanhamento efetivo da pessoa. 
Fica claro também, a dificuldade do profissional em lidar com o sofrimento do outro e, frente à própria dificuldade, ele passa o diagnóstico para que outra pessoa comunique ao paciente, conforme relata o sujeito 03:

“... o pior de tudo pra mim foi a minha mãe saber, que eu acho que ela era a última pessoa a poder saber, né? E ela foi a primeira. Porque o médico não me comunicou, não comunicou ninguém que ia fazer o exame. Até isso eu achei errado. Porque eu acho que é essencial você ter a autorização do paciente pra fazer o exame. E tem que dar notícia com autorização do paciente. Não, ele fez o exame sem minha autorização, sem falar nada comigo e ainda foi direto na minha mãe, não falou comigo. Ele queria que minha mãe me desse, me falasse... (...)ele queria um meio de sair fora".

No relato acima, observa-se uma total desqualificação da paciente enquanto sujeito de sua saúde. Ela não foi comunicada do exame e, tampouco do diagnóstico. Foi usurpada em sua individualidade. Foi exposta em sua intimidade. Foi desrespeitada enquanto indivíduo e cidadão. Não the foi possibilitada sua condição de pessoa com papel ativo e determinante na relação com o profissional que o atende.

As dificuldades em falar da Aids e em enfrentar uma possível recusa do paciente em realizar o teste são alguns dos motivos que levariam os profissionais a não informá-lo sobre a solicitação do teste de HIV. A idéia do consentimento livre e esclarecido, atualmente um dos mais importantes princípios de ética em medicina, se adequa perfeitamente a essa situação. A autonomia do paciente se refere a possibilidade de fazer uma escolha, no entanto esta escolha não poderá ser pautada apenas no medo ou desejo, deverá ser informado das conseqüências de sua escolha. Ou seja, mesmo enfatizando o direito do paciente em fazer ou não o exame, é dever do profissional, em qualquer situação de risco de doença, oferecer os recursos disponíveis e procurar convencer o paciente dos benefícios do tratamento, mesmo 
que esses sejam poucos em relação aos problemas que terá que enfrentar diante de um resultado positivo. A situação da testagem pré-natal é um exemplo de que, mesmo sendo rotina, o paciente deve ser informado sobre os exames solicitados, devendo ser justificados de forma a convencer dos benefícios em realiza-los.

Tem-se, assim, um modelo de saúde em que as forças psicossociais não desempenham um papel importante e há uma propensão dos profissionais de ignoralas. Assim, na maioria das vezes, o "sofrimento do paciente é tratado por meio da negação e suprimido por analgésicos" (Figueiredo, 1997, pag. 01). Desta forma, o profissional de saúde não se aproxima da realidade única, subjetiva do paciente. Esta desvitalização do atendimento, além da falta de espaço para os sentimentos fluírem pode ser observado no seguinte discurso:

"Comecei a fazer os exames pré-natal, mas ninguém me falou nada. Só fiquei sabendo na hora que tive o neném. Eu fiquei 15 dias lá, internada, eu querendo ir embora e ninguém falava nada. Até que vieram me falar. Me deram um comprimido primeiro... (Sujeito 09).

Presa de exigências conflitantes que envolvem simultaneamente responsabilidade e auto-preservação, o profissional de saúde se vê frente a situações ambivalentes. E, diante deste quadro, que determina um atendimento que se caracteriza pela ênfase na competência técnica, o paciente se ressente de uma abordagem que permita estender um atendimento às suas necessidades psicossociais:

Eu acho que ela (a médica) deveria chegar, conversar, explicar tudo direitinho... Porque ela deu pra mim assim, na lata, e saiu. (Sujeito 07).

É fundamental reconhecer que os profissionais que trabalham com DST/Aids, deparam-se dia-a-dia com situações estressantes - entrega de diagnóstico 
de exame sorológico, crises conjugais, dependência de drogas, falta de recursos, dor, desespero, rupturas, etc - que impõem a necessidade de superação de limites institucionais e pessoais. Neste sentido, a criação de espaços de reflexão e discussão, além de suporte psicológico, beneficiaria tanto ao médico como aos seus pacientes.

Diante do confinamento da prática em campos estanques, onde, por um lado, a busca pelas questões subjetivas do atendimento colide com o caráter assistemático da intervenção e, por outro, as questões técnicas prevalecem pela desvitalização e objetivação da relação terapêutica, a formação profissional se volta para conhecimentos instrumentais que particularizam a ação e especializam as intervenções. Perde-se, no processo, a capacidade de síntese e a reflexão se dá nos limites de cada especialidade. A busca pela recuperação do pensamento conceitual vem mobilizando alguns profissionais de saúde e colocando na ordem do dia os limites da formação acadêmica e de alguns enfoques inspirados em concepções ingênuas sobre a multidisciplinaridade (Figueiredo, 2000b).

A ativação de grupos com pacientes com AIDS, desenvolvidas pelo PAPSI junto a UETDI - Unidade Especial de Tratamento de Doenças Infecto-Contagiosas do Hospital das Clinicas, em Ribeirão Preto - SP, colocou em evidência alguns subprodutos importantes do trabalho de atendimento, no sentido de aperfeiçoamento profissional, onde sínteses periódicas possibilitam estudos em profundidade sobre as atividades realizadas e a elaboração de documentação relacionada com a formação e reprodução de recursos. Desta forma, além do atendimento psicossocial do paciente, os grupos se constituíram em laboratórios de grande valor para a criação de recursos e a formação de background sobre os problemas psicossociais decorrentes da Aids. 


\section{- Equipe Multidisciplinar}

A estrutura dos serviços com base na multidisciplinaridade, de acordo com a pesquisa de Silva et al (2002), não tem garantido respostas adequadas. Ainda que no campo intelectual este trabalho tenha emergido como possibilidade, na prática ele está fortemente organizado em torno do modelo médico, em que as demais áreas agregam seus trabalhos em torno da racionalidade clínica e na busca de autonomia, resultando na compartimentalização do atendimento. As práticas dos diferentes profissionais são freqüentemente isoladas e muitas vezes concorrentes, demonstrando dificuldade de interação entre diferentes competências técnicas.

A busca da integralidade, muitas vezes é confundida com ações de encaminhamento dos usuários, configurando em justaposição de ações. Ou ainda, se tem a percepção do trabalho multidisciplinar como estratégia para reforçar prescrições, reforçando a convivência segmentada e autonomizada das diferentes competências técnicas.

Estes aspectos podem ser observados no relato revoltado do Sujeito 06:

É uma confusão, porque daqui me mandam pro postinho lá perto de casa. Lá não tem infectologista. Dali me mandam pro ProntoSocorro. Do Pronto-Socorro mandam pro Postinho da (rua) Cuiabá. Aí, eles marcam consulta pra daqui a um mês. Aí, depois tem que vir buscar uns papéis e tirar um monte de sangue. Mas eles marcam assim... Ah! Lá é muito complicado, porque eles, por exemplo, se eu vou fazer um exame pra contar aquele negócio de CD4, eles marcam pra três ou quatro meses na frente, porque tem muita gente. Mas, desse jeito pra mim não dá, porque quando eu conseguir fazer este exame, já tô morrendo, porque eu não tô fazendo nenhum tratamento. Não, dessa vez eu vou falar: olha, não me alterem, se me mandarem pra essa UETDI, eu não vou a lugar nenhum. Ah não. Eles brincam muito com a gente, não dá, não. 
Estes dados indicam pistas importantes para uma reorientação na abordagem do paciente que leve em conta uma visão da pessoa como um todo, não fragmentada pelas várias especialidades técnicas, que priorize o vínculo pessoal profissional-paciente, que seu sofrimento seja acolhido e considerado nos vários aspectos.

No processo de apropriação da doença, conforme Silva (2002), os usuários contribuem para a compreensão da necessidade de articulação das diversas práticas de trabalho existentes nos Serviços de Saúde. Da mesma forma, ao apreender a Aids não apenas no âmbito biomédico, mas também em suas dimensões sociais, culturais e psicológicas, os profissionais reiteram a necessidade do aporte de vários campos do conhecimento na atenção às pessoas com Aids. Ressalta-se assim, o fato de que nem os profissionais podem ser reduzidos às suas competências técnicas e nem os usuários a passivos objetos de intervenção.

Estudos sobre o trabalho de equipes multidisciplinares(Silva et al, 2002; Figueiredo \& Ayres,2002; Buchalla \& Paiva, 2002), buscando ampliar o foco do atendimento para além da racionalidade clínica e do modelo médico tradicional (que busca exclusivamente o "paciente aderido" ao preservativo ou ao medicamento), indicam que alterações nas circunstâncias em que essa assistência interdisciplinar se realiza têm impacto perceptível na assistência. Confirmam as sugestões para o desenho de programas de prevenção do HIV e da Aids que apontam a necessidade de ampliar a integralidade do atendimento e o aconselhamento para todos os momentos de contato com os participantes das ações de saúde, apesar dos obstáculos para superar a compartimentalização entre as várias especialidades profissionais ou a sobrecarga de trabalho nas unidades básicas de saúde. 
Há que se destacar a importância desta equipe multidisciplinar como estratégia de construção de práticas assistenciais integrais, qualificando a assistência e propiciando transformações nas relações tradicionalmente estabelecidas pelos serviços públicos e de saúde. A perspectiva de existência de um espaço de trocas favorece o compartilhamento de angústias, dúvidas e dificuldades vividas, aliviando o stress, fortalecendo a equipe, estimulando pesquisas e proposições onde os profissionais de saúde, assim como os usuários, poderão resgatar suas possibilidades de transformação das relações de poder, propondo alternativas assistenciais criativas e participação nas instâncias decisórias.

Mais que equipes técnicas, as equipes multidisciplinares que tratam o fenômeno AIDS devem se constituir enquanto grupos estratégicos, onde a real dimensão do problema passa pela luta por melhores condições de trabalho e pela inserção do profissional nos processos de concepção e organização do atendimento enquanto todo. Assim, além de se estender às questões da organização da práxis, a formação deve ser reorientada para a capacitação do profissional de saúde no sentido de poder sistematizar e aproveitar a aprendizagem informal, acumulada pela experiência no trato com o paciente (Figueiredo, 2000a).

Os discursos aqui analisados não retratam necessariamente a realidade dos serviços, mas antes, são a ressignificação de sua realidade pelas usuárias destes serviços. Essa é uma dimensão importante e assinala como a discussão profissional de saúde-paciente está comprometida com os valores da esfera privada. Não podem ser realizadas para um universo maior, pois fazem parte de um contexto, são antes pistas para contribuir com o debate sobre a relação profissional de saúde-paciente e destes com os serviços de saúde. 


\section{- CONSIDERAÇÕES FINAIS}

A difusão das idéias do amor romântico, profundamente envolvidas com as transições sócio-econômicas do século XVIII, afetou a vida social como um todo, reordenando as condições da vida cotidiana através: (1) da criação do lar, a partir da divisão das esferas domésticas e públicas; (2) da invenção da maternidade, com a idealização do papel da mãe; (3) do casamento por amor e não mais por alianças familiares.

O casamento passa a ser um acordo ou escolha entre pessoas que elegem um pacto de amor, indissolúvel, com a intenção de desenvolver um projeto de vida em comum, que implica em criar e amar sua descendência.

Para tanto, o homem assume a responsabilidade pelo sustento econômico da família e a mulher a criação dos filhos e a organização doméstica. Isto significa que a linguagem política, o poder e o dinheiro se inscrevem como naturais do mundo masculino, enquanto que o feminino se identifica com um mundo sentimentalizado, socialmente subalterno, de retaguarda e sem característica produtiva.

Assim, o amor romântico se estabeleceu como norma de conduta emocional, respondendo aos anseios de felicidade, tornando o casamento o objetivo primário das mulheres.

Cria-se aí uma forma de subjetividade própria das mulheres, que consiste em ser do outro, em detrimento do ser de si, o que vai se constituir em ponto de fragilização e vulnerabilidade. 
Nos dias atuais, mesmo sofrendo transformações, permanece o cerne moral e a intensidade passional do amor. O amor e o casamento ainda são mantidos como ideal de felicidade e orientadores de conduta, repercutindo no modo de agir e atuando no processo de formação de identidade.

O conjunto das significações que o imaginário social instituiu com a modernidade em relação à família, sustenta até hoje as novas formas que o público e privado adquirem, delimitando o conjunto de atribuições, prescrições e restrições do feminino e masculino.

Organizam-se, assim, regimes de verdade que persistem pela naturalização. Estas cristalizações de sentidos, os mitos sociais, vividos pelos indivíduos como realidade objetiva, organizam as formas dos laços sociais, ou seja, institucionalizam tanto as relações materiais como as subjetivas das pessoas. Ainda mais, produzem sistemas de significação que tornam possível a produção de consensos de uma sociedade.

Portanto, ao tratar das questões que tornam a mulher vulnerável à soropositividade ao HIV, se faz necessário elucidar como os dispositivos são postos em jogo em determinado momento histórico, favorecendo, assim, a desnaturalização de situações tidas como naturais da condição feminina e da relação entre os gêneros. Desnaturalizar significando a retirada do campo da natureza daquilo que é, na verdade, construído historicamente pelos homens em suas práticas sociais e políticas.

É importante ressaltar que, enquanto construções histórico-sociais, estes aspectos variam em cada cultura e, dentro dela, em diferentes classes sociais, que se tornam evidentes tanto em significados quanto em recursos de enfrentamento. 


\section{- Histórias de Vida}

As histórias de vida mostraram-se um recurso adequado para colocar em evidência a experiência das mulheres soropositivas em relação à sua trajetória e com os significados atribuídos por elas a uma série de aspectos que relacionam tais trajetórias, em cujo percurso sucedeu a infecção pelo HIV. Nesta construção intervem elementos extraídos da história individual, das experiências compartilhadas e dos sistemas de crenças e valores dos grupos a que pertencem.

Os relatos das entrevistas revelam uma particular condição de vulnerabilidade, ancorada em histórias pessoais de carências afetivas, vividas especialmente na infância.

Em todos os casos, sem que isso implique em colocar a família de origem como agente causal, existe uma caracterização do núcleo familiar como carência afetiva. As famílias são descritas como conflitivas, associadas a aspectos como: mortes, separações dos pais, separações de irmãos, famílias mal integradas, violência física, alcoolismo, pobreza e ausência de perspectivas. São aspectos que remetem a sensação de solidão, abandono e falta de continência afetiva vividas por estas mulheres, empurrando-as ao crescimento acelerado, passando da infância diretamente para a vida adulta, através do casamento, como meio de alcançar a felicidade.

Trata-se, pois, de contextos relacionais nos quais se busca reverter carências prévias, obstruindo qualquer consideração relativa a necessidade de evitar riscos, configurando-se em situações de vulnerabilidade. 
Nestes processos, o imaginário de doação total de si é a contrapartida da ilusão de receber do outro também um tributo tal que seja capaz de afastar toda incerteza. Assim, no mito do amor romântico, para que o ideal amoroso se realize, é necessário a fragilização da subjetividade das mulheres.

Essa subjetividade, com base no sentimental, presente inclusive em mulheres com independência econômica, cria condições para um particular tipo de dependência pela qual ela espera, talvez, demasiadas coisas do amor de um homem. Principalmente quando o homem em questão não é somente seu objeto amoroso, mas também quem ministra seu reconhecimento.

A presença de uma subjetividade organizada no sentimental, portanto fragilizada, implica um escasso nível de individualidade, uma ordem de prioridade sentimental e idéias de postergação mais do que de êxito pessoal. A falta de uma consciência crítica as leva a naturalizar este estado de coisas, levando à limitações importantes para a criação de estratégias que revertam sua condição. Essa situação dá espaço a instituição de relações de poder que geralmente desfavorecem as mulheres.

Este poder nunca se apóia exclusivamente na força, mas sim em elementos de legitimação e naturalização, produzidos através de representações, crenças e discursos, que se transformam em normas que são vividas no cotidiano.

É importante observar que, em muitos casos, a subordinação não é vivida como tal. Ela pode revestir-se de sentimentos, afetos, ternura, amor, ou seja, as formas de dominação podem ser sutis, consentidas e aceitas pelas mulheres como 
algo que está na natureza das coisas e que se exerce, principalmente pela via dos sentimentos.

Visto que é no espaço da conjugalidade e da família o lugar onde as reciclagens da subordinação de gênero se encontram mais à vista e ao mesmo tempo, mais ocultos, torna-se necessário discutir as questões que permitam pensar a distribuição de posicionamentos de homens e mulheres no espaço público e privado.

\section{- A Soropositividade para o HIV no Cotidiano}

Depois do impacto sofrido pelo diagnóstico, vem a necessidade da reestruturação e manutenção da vida em seus vários papéis. A soropositividade rompe com o silencio, revela segredos, levando ao confronto de situações que abalam o sistema de valores destas mulheres. Assumir sua condição de soropositiva significa ter várias outras perdas, inclusive da identidade construída durante anos.

A construção de uma nova identidade após o adoecimento e o retorno à normalidade - que não é saúde - constitui-se num processo dinâmico e complexo, que consiste em assimilar e produzir, de forma ativa, conhecimentos e formas de ação.

Entretanto, a interpretação da doença tem uma visão temporal, ou seja, o conhecimento e o sentido dado a Aids estão continuamente sendo reformulados e reconstruídos em decorrência dos processos interativos. Isso faz com que, com o passar do tempo, para estas mulheres, a doença seja levada em conta sem que ocupe o centro de sua vida. Integra-se nas esferas da vida como um aspecto a mais, sem que isso implique sua banalização. Trata-se de um tipo de gestão racional da doença, em 
que as angustias despertadas pelo diagnóstico é canalizada para as questões do cotidiano.

Fica evidenciado que a Aids está vinculada com distintos tipos de vulnerabilidades. Além disso, pode-se observar momentos a partir dos quais realizaram uma reflexão da vida, da imagem de si mesmo e de seus comportamentos. Entretanto, essa reavaliação não foi suficiente para efetivarem mudanças no que se refere a manutenção do estilo de vida, por considerarem que não há nada para ser mudado.

As questões que concorrem para que essas mulheres não levem em conta os riscos da Aids, implicam em outros riscos que surgem de demandas e requerimentos emanados da vida cotidiana, em cuja hierarquia não figura a Aids.

\section{- A mulher soropositiva para o HIV como sujeito da saúde}

A Aids trouxe consigo a necessidade de reformulação da estrutura do atendimento em saúde, impondo a necessidade de escutar o paciente como um todo e não apenas examinar o órgão doente. Trouxe também a necessidade de lidar com as questões afetivas, antes relegadas ao segundo plano. E assim, tornou visível o despreparo e a desorientação que envolve os profissionais de saúde no trato psicossocial da doença.

O principal aspecto apontado nesta pesquisa em relação ao atendimento nos serviços de saúde é até relativamente simples e não depende de situação complexa para a sua solução: as mulheres precisam ser ouvidas. Ao relatar as histórias de vida, as experiências fragilizadoras e os caminhos encontrados para romper com o 
determinismo, elas vão, ao mesmo tempo, construindo formas de enfrentamento da situação atual.

Para os profissionais de saúde, o momento da escuta serve para buscar, na história de vida de cada paciente, a melhor forma de introduzir as orientações e prescrições, de modo que sejam adaptadas ao contexto sócio-cultural e à realidade de cada um.

De acordo com os relatos deste estudo, observou-se que o encontro com o paciente não está sendo utilizado para que se estabeleça um diálogo, mas conduzem à repetição de preceitos normativos, além de uma postura de distanciamento, com o exercício da autoridade médica dicotomizada em relação às expectativas e vivências do paciente, agravadas pelo pouco tempo disponível para o atendimento.

Diálogo pressupõe troca, onde o conhecimento prévio e as crenças dos pacientes, que orientam seu comportamento cotidiano, possam ser relativizadas conjuntamente e, dessa forma, o próprio usuário possa identificar com mais clarezas suas demandas e reconhece-las como pertinentes.

Entretanto, essa troca só é possível com o reconhecimento de que o usuário detém um conhecimento prévio, baseado nas experiências e no saber de senso comum, que são bastante arraigados e orientadores das condutas cotidianas.

Por outro lado, reconhece-se que as questões trazidas pela Aids, colocam os profissionais de saúde diante de um exercício interno constante e exigem demais de um profissional que não teve, necessariamente, em sua formação acadêmica, o preparo para lidar com tais situações. 
Outro aspecto observado se refere a pouca visibilidade dos casais nos serviços de saúde, onde se trata prioritariamente o indivíduo doente, remetendo as questões do casal, de ordem mais afetiva, à esfera privada.

A conjugalidade, inserida nas questões de sócio-culturais de gênero, está intimamente ligada aos aspectos de prevenção e tratamento, estando presentes nas situações de enfrentamento e gerencia da soropositividade. Elas vão influenciar o uso ou não de preservativo nas relações sexuais e, portanto, a prevenção. Vão estar presentes na maior facilidade ou dificuldade de saber e revelar o diagnóstico. No papel assumido por cada membro do casal (feminino/cuidador, masculino/cuidado). $\mathrm{Na}$ diminuição do risco da contaminação, onde o risco de ficar sozinha, não ter filhos, não ter companheiro, não ter amor, se sobrepõem ao risco da Aids.

Surge, então, o questionamento sobre o lugar do parceiro nos serviços de saúde. No caso da sorodiscordância, essa questão remete à priorização da urgência conferida à doença pelo sistema de saúde. Como o parceiro é negativo, não é considerado sujeito de atendimento, não é urgência, portanto, não têm espaço nos serviços de saúde. Tratando-se de casais soroconcordantes, talvez a dificuldade em incorporar o parceiro seja conseqüência da fragmentação das especialidades dentro dos serviços de saúde, onde cada um é encaminhado para profissionais diferentes (por exemplo: ginecologista/urologista), ou ainda para profissionais diferentes dentro de uma mesma especialidade, por serem considerados enquanto indivíduos e não enquanto casal.

Essa questão remete para a importância da formação de equipes multidisciplinares na busca da ampliação do foco de atendimento para além da racionalidade clínica e do modelo médico tradicional. Os inúmeros estudos citados 
neste trabalho permitem pontuar que, nenhuma delimitação temática pode operar com eficácia a partir de um só campo disciplinário. O fechamento disciplinário gera reducionismos e restrições diversas. Abre-se a necessidade de superar os conhecimentos dicotomizados e trabalhar com equipes e enfoques de principio multidisciplinar, podendo chegar a integração transdisciplinária, sustentada a partir de uma elucidação crítica dos discursos totalizadores, buscando novas formas de articulação.

Por fim, é imprescindível a garantia da sustentabilidade das ações de intervenção, o que remete ao papel do Estado e dos agentes locais no que refere a sua continuidade, recursos e modelos de organização do trabalho. Tais ações devem ser encaradas enquanto um processo contínuo e não como simples espaço de ações pontuais ou de prática esporádica.

O discurso destas mulheres permite compreender porque é mais adequado falar de vidas que transcorrem em risco. A vulnerabilidade de gênero se reforça quando se somam outras desigualdades em termos político, econômico e social, tanto no âmbito dos relacionamentos, como da sociedade em geral. Ou seja, a Aids afeta as mulheres, porém não afeta a todas por igual.

As mulheres que estão particularmente em risco são as que têm vulnerabilidade exacerbada, o que muitas vezes as obriga a tolerar determinadas situações que em outro contexto não ocorreriam, transformando os relacionamentos em relações de poder. Poder este que não se apóia exclusivamente na força, mas sim em elementos de legitimação e naturalização que são vividos no cotidiano. Desta forma, a subordinação não é vivida enquanto tal, mas podem ser sutis, consentidas e 
aceitas pelas mulheres como algo que está na natureza das coisas e que se exerce, principalmente, pela via dos sentimentos.

Os relatos das entrevistadas delimitam três aspectos essenciais a serem considerados em programas de intervenção com mulheres:

1 - as trajetórias sociais dos indivíduos, permitindo identificar certas regularidades entre momentos específicos de vulnerabilidade;

2 - a dinâmica das relações afetivas, na medida em que permitem identificar o tipo de encontros que tem influenciado na vulnerabilidade dos indivíduos;

3 - os elementos do contexto sócio-histórico, cujo controle escapa à influencia direta dos indivíduos e que podem fragilizar seus recursos pessoais.

Como é óbvio, os dados que foram apresentados somente tem sentido se servirem como insumos para intervenções preventivas ou de melhora da qualidade de vida das pessoas soropositivas. Neste sentido, como consequiência e conclusão deste estudo, será apresentado a seguir um Projeto de Intervenção visando a redução da vulnerabilidade e construção de modos de enfrentamento à Aids para mulheres, a ser desenvolvido como continuidade desta pesquisa. 
UNIVERSIDADE DE SÃO PAULO

FACULDADE DE FILOSOFIA, CIENCIAS E LETRAS DE RIBEIRÃO PRETO DEPARTAMENTO DE PSICOLOGIA E EDUCAÇÃO

Vulnerabilidade e Construções de Enfrentamento da Soropositividade ao HIV

Projeto de Intervenção com Mulheres

Ana Alayde Werba Saldanha

Orientador: Prof. Dr. Marco Antonio de C. Figueiredo

Ribeirão Preto - SP, 2003. 


\section{INTRODUÇÃO}

Com base nas inúmeras pesquisas realizadas na última década, Parker \& Camargo Jr. (2000) agruparam os fatores estruturais facilitadores da disseminação do HIV/AIDS ${ }^{11}$ em três categorias distintas, mas interconectadas:

1 - (Sub)desenvolvimento econômico e pobreza;

2 - Mobilidade, incluindo migração e trabalho sazonal;

3 - Desigualdade de gênero.

Para estes autores, os complexos processos de globalização e de reestruturação da economia mundial, característicos das décadas finais do século XX, iniciada na década de 70 , bem como a série de transformações subseqüentes nas estruturas das sociedades, comunidades e famílias, são, talvez, os fatores relativos mais importantes a serem buscados no entendimento da evolução global da epidemia do HIV/AIDS.

Estas tendências básicas, segundo Parker \& Camargo Jr. (ibid.) também foram identificadas ao que poderia ser descrito como progressiva feminização da pobreza e miséria, referindo-se ao fato de que, embora as mulheres tenham sido incorporadas ao mercado formal de trabalho, as que vivem em situação de pobreza tornam-se cada vez mais excluídas, não apenas devido à opressão baseada em classe, mas também à opressão baseada em gênero. Tais transformações têm impactado

\footnotetext{
${ }^{11}$ AIDS vem da expressão em inglês Acquired Imunedeficiency Síndrome, traduzida em português para Síndrome da Imunodeficiência Adquirida, e tem sua origem no HIV (human imunodeficiency vírus ou vírus da imunodeficiência humana). Neste trabalho usaremos a sigla AIDS.
} 
desproporcionalmente a vida das mulheres, mesmo em meio a uma série de ganhos importantes em termos do feminismo e da conquistas de direitos civis e políticos adicionais.

O Brasil pode ser visto como uma complexa síntese onde estão virtualmente presentes todos os diferentes fatores sócio-econômicos identificados como estruturantes da vulnerabilidade relacionada ao HIV/AIDS. De acordo com Parker \& Camargo Jr. (ibid.), formas variadas de desigualdade e opressão, em conjunto com a variada gama de fatores estruturais e ambientais, combinam-se no território brasileiro para produzir e reproduzir forças sociais que foram identificadas, em âmbito internacional, como motores da epidemia: os movimentos migratórios, a falta de poder das mulheres sujeitas simultaneamente à opressão e econômica e de gênero, o encolhimento do mercado formal de trabalho e a desintegração social produzida pelo crime organizado e o tráfico de drogas.

Os fatores políticos econômicos que impulsionaram a epidemia de HIV/AIDS estão também intimamente ligados à organização social das estruturas de gênero e sexualidade, cujas hierarquias fazem das mulheres - em especial àquelas dos segmentos de baixa renda - extremamente vulneráveis à infecção pelo HIV.

Entretanto, Bastos (2000) ressalta como ponto central da questão da feminização da epidemia de HIV/AIDS, a questão de gênero. O tratamento desigual dado aos gêneros, em termos políticos, culturais e sócio-econômico têm uma dimensão macro e micro-social, compreendendo a não observância dos direitos fundamentais, relações desiguais de poder e acesso diferenciado a bens materiais e simbólicos, tendo lugar nas famílias e parcerias, como também na sociedade, organizadas em sistemas de crenças e códigos de valores. 
Freqüentemente estas desigualdades se superpõem, gerando efeitos sinérgicos, que multiplicam os riscos a que estão submetidas as mulheres. A combinação da violência material e simbólica, da dupla moral no que diz respeito ao comportamento sexual de homens e mulheres no âmbito da família e da sociedade, da assimetria na capacidade de tomar decisões e efetivá-las, e a ausência de canais por onde manifestar queixas e resolver pendências (por diálogo ou via legal), torna mais difícil para a mulher ter acesso à informações adequadas e atualizadas. E, uma vez dispondo delas, modificar seus comportamentos e manter estas mudanças nas interações cotidianas.

A história do feminino é marcada por mudanças que, ao mesmo tempo em que abrem perspectivas para as mulheres, também impõem restrições que justificam a sedimentação de uma interação polarizada entre homens e mulheres, na qual a mulher vem ocupando, por diversos motivos, o papel inferior. No centro destas motivações está o aspecto econômico. Observa-se que foi a partir da mudança no modo de produção, que tomou impulso o sistema de organização patriarcal que resiste até hoje (Rezende, 1986;Fischer \& Marques, 2001; Reis, 2002; Campos, 2000). Outro dado relevante a ser considerado é a assimetria sexual das expectativas afetivas: enquanto as conquistas masculinas são valorizadas pela quantidade, as mulheres continuam fixadas no aspecto romântico e exclusivista de cada envolvimento amoroso, mantendo o casamento como um objetivo primário.

A difusão das idéias do amor romântico, profundamente envolvida com a transição sócio-econômica do século XVIII e início do século XIX, afetou a vida social como um todo, reordenando as condições da vida cotidiana. Dentre os quais, Giddens (1993), cita: (1) a criação do lar, a partir das esferas domésticas e publicas; 
(2) a modificação das relações entre pais e filhos, aliada à diminuição do tamanho das famílias, o que permitiu o controle e cuidado das mães para com os filhos, que passaram a ser vistos como vulneráveis e necessitando de afeto; e (3) a invenção da maternidade, com a idealização do papel da mãe. Assim, com a divisão das tarefas de ação, a promoção do amor tornou-se predominantemente função das mulheres, estando associada à subordinação da mulher ao lar e ao isolamento do mundo externo, além da associação do amor com o casamento e a com a maternidade (Lobato, 1997; Giddens, 1993; Costa, 1999).

Desta forma, experimentar a realização sob o modo do amor romântico era uma obrigação cultural, que se sustentava na repressão da sexualidade feminina, na crença da natureza do homem, na desigualdade social entre homens e mulheres, na firmeza dos afetos familiares, na importância do convívio doméstico, nos preconceitos da moralidade burguesa, no agudo sentimento de responsabilidade para com o futuro dos filhos e dos ascendentes, etc. Assim, o amor romântico, quando se estabilizou como norma de conduta emocional, respondeu aos anseios de autonomia e felicidade pessoais, transformando-se em um elemento de equilíbrio indispensável. E, ainda hoje, o amor é mantido como um ideal de felicidade, orientador de conduta, repercutindo no agir moral.

Neste aspecto, Solomon apud Costa (1999), afirma que, mesmo sofrendo transformações, permanece o cerne moral e sua intensidade passional do amor. Nos dias atuais, o amor pode ser uma afeição mais geral de estar com, de ser apreciado, de ser feliz junto, de querer o melhor para o outro, de fazer tudo pelo outro. No entanto, em função das inseguranças constitutivas da subjetividade moderna, é o amor que provê o sentido que mais se necessita, o sentido de pertencimento, pelo 
processo de formação de identidade. Ou seja, o amor atua como o lugar de reasseguramento da identidade.

Em nossos dias, ainda vivendo a acomodação das enormes transformações sociais, econômicas e culturais que tem colocado, homens e mulheres, diante da necessidade de reestruturação de valores, nos deparamos com fenômenos sociais perturbadores, causados por uma doença, a AIDS, que além de atingir o estado biológico, faz ressurgir aspectos conflituosos das relações humanas, tais como as relações de poder entre os gêneros.

\section{JUSTIFICATIVA}

A Aids tem mostrado a inadequação de uma abordagem que busca compreender e controlar a doença nos limites do laboratório, forçando assumir outras posturas teórico-metodológicas.

A síntese de vários estudos e avaliações (Ayres, 2002; Paiva, 2002; Seffner, 2002; Saldanha \& Figueiredo, 2002 ; Kornblit, 2000; Figueiredo, 2000) relacionados aos modelos de intervenção do HIV/Aids, permitiu a pontuação de alguns fatores que podem estar dificultando a implantação de estratégias efetivas e, portanto devem ser evitados:

- o enfoque individualista, que converte os sujeitos em entidades alienadas de seu contexto social e relacional;

- o caráter unidirecional das intervenções, onde o sujeito torna-se passivo, alvo de intervenções nas quais não toma parte; 
- a busca da objetividade na prática institucionalizada, sem considerar que nem sempre o que o profissional considera ser o melhor para a vida das pessoas corresponde ao referencial do sujeito;

- a falta de preocupação com o ambiente macrossocial, compreendendo tanto as relações materiais derivadas dos processos econômicos e sociais, quanto as estruturas simbólicas construídas pela cultura;

- a ênfase dada aos comportamentos observáveis, que ignora o pano de fundo subjetivo e interacional.

Sendo assim, para o sucesso de uma intervenção, Monteiro (2002) se apóia nos pressupostos de que os esforços voltados para a transformação de práticas dos sujeitos, além de aspectos relacionados à ordem econômica, política e social, devem levar em conta a sua dimensão simbólica, o que implica em considerar a visão de mundo do sujeito que será alvo da ação.

Ao tratar-se de mulheres, o maior agravante da vulnerabilidade é evidenciado pelas limitações no espaço de suas relações pessoais, principalmente no que se refere à relação conjugal, local onde as reciclagens de gênero se encontram mais visíveis e, ao mesmo tempo, mais ocultas. Sua prática cotidiana naturaliza as relações de dependência objetiva e subjetiva, implicando um escasso nível de individualidade, uma ordem de prioridade sentimental e ideais de postergação, mais do que o êxito pessoal (Fernandez, 1994).

O discurso da natureza feminina, os mitos da maternidade, da passividade e o discurso do amor romântico subsidiaram a construção histórica de uma forma subjetiva própria das mulheres - o ser do outro em detrimento do ser de si - tendo 
como conseqüência sua fragilização através de diversas formas de dependência objetivas e subjetivas.

Os mitos e os discursos que a sociedade institui são cristalizações de significados que operam como organizadores de sentido no agir, pensar e sentir dos homens e mulheres que conformam esta sociedade, sustentando a orientação e legitimação de suas instituições (Fernandez, ibid). Assim, produzem narrativas morais, religiosas e cientificas que legitima - geralmente naturalizando - esta situação.

A falta de consciência crítica faz com que as mulheres naturalizem essa situação, concorrendo para uma limitação na busca de estratégias que revertam essa condição.

É preciso considerar que, se anteriormente a dependência econômica, a ignorância intelectual e a passividade foram condições materiais que possibilitaram a permanência da mulher no mundo privado, atualmente se dá através do controle das subjetividades, estabelecendo formas de dependência mais invisíveis, porém não menos eficazes. É preciso, portanto, que ocorra uma ruptura da cumplicidade na subordinação para que estas mulheres se tornem sujeitos de sua história.

Segundo Guerriero et al (2002), a combinação marido querendo firmar-se como homem e esposa ingênua paralisa o casamento num patamar em que o mais importante passa a ser representar papéis. Ambos parecem, segundo o autor, aprisionados às idéias de como deve ser uma mulher, um homem e a relação entre eles, distanciando-se, assim, da possibilidade de construção de uma relação criativa. Trabalhar nesse aspecto coloca-se como essencial para que se reduza o risco ao HIV. 
De toda forma, esses processos não produzem submissões massivas: cada mulher se insere em certo grau de submissão, porém também organiza, consciente ou inconscientemente, formas de resistência, de contraviolência e contrapoder, sempre no marco das relações gerais de subordinação material, subjetiva e sexual em que se encontram (Fernadez, ibid.). A partir daí é que terão lugar os sistemas de alianças, as confrontações sutis ou abertas, que caracterizam cada história conjugal ou familiar.

Sendo assim, se é no âmbito da família e da conjugalidade que se elaboram as condições de subordinação de gênero, paradoxalmente, é neste mesmo espaço que se originam os graus possíveis de autonomização.

Partindo destes pressupostos e visando a redução da vulnerabilidade e construções de modo de enfrentamento à soropositividade pelo HIV, o presente projeto tem por objetivo, através de grupos de mulheres, identificar os conflitos e contradições, possibilitando a ressignificação de suas representações, experiências e práticas, apontando para a possibilidade de transformação no modelo e nas práticas relacionadas à saúde e qualidade de vida.

\section{MÉTODO}

\section{1 - Local de Desenvolvimento:}

Foi constatado que os cuidados com a saúde pelas mulheres ocorrem com maior freqüência pela necessidade do pré-natal (Saldanha \& Figueiredo, 2001). Sendo assim, o sistema de saúde, mais especificamente os Serviços de Planejamento Familiar, constitui um "lócus" privilegiado para o desenvolvimento deste projeto. 


\section{2 - Participantes do Estudo}

Mulheres, soropositivas ou não, usuárias do serviço de saúde, que se disponham a participar dos encontros.

\section{3 - Procedimento}

Serão formados grupos estruturados, com agendamento fixo e coordenação centralizada.

Serão formados grupos distintos para mulheres soropositivas e mulheres soronegativas. E, dentro desta especificação, divididos de acordo com a faixa etária adolescente, adulto e terceira idade - para a melhor contextualização dos temas a serem debatidos.

A importância do trabalho em grupo deriva do seu significado enquanto um

"espaço onde a afetividade pode fluir $e$ a auto-determinação $e$ a independência venham tomar o lugar da contemplação e da impotência, servindo para que, neste espaço constituído, o usuário possa se apropriar, como legítimo dono, da sua própria criação. Para os profissionais, a continuidade dos trabalhos pode representar a busca pela reflexão e do pensamento conceitual retido nas entrelinhas da aprendizagem informal, onde as possibilidades de construção e de conhecimento cedem o lugar para a rotina e a naturalização" (Figueiredo, 2000a, p. 30).

Serão delineados quatro encontros: para cada um deles será escolhido um tema principal a ser explorado e selecionadas as estratégias do trabalho em grupo.

Para compreender o modo como os sentidos são produzidos e assim promover uma reflexão que possibilite a "desconstrução" de conceitos e crenças que, enquanto tais, colocam-se como obstáculos para que outros sejam construídos, 
considera-se necessário trabalhar na interface dos três tempos, conforme citado por Spink \& Medrado (2000): o tempo longo, o tempo vivido e o tempo curto. O tempo futuro será analisado a partir da construção de metas e projetos.

O tempo histórico (longo) constitui o espaço dos conhecimentos produzidos e re-interpretados por diferentes domínios e tradições do senso comum. São conhecimentos que antecedem a vivência da pessoa, mas se fazem nela presentes por meio de instituições, modelos, normas, convenções, enfim, da reprodução social.

O tempo vivido corresponde às experiências dos indivíduos no curso da sua história de vida, como processo de ressignificações desses conteúdos históricos, a partir dos processos de socialização primária e secundária. É o ponto de referências afetivas, no qual são enraizadas as narrativas pessoais e identitárias.

O tempo curto é o momento concreto da vida social, vista como atividade de caráter interativo. Nesse momento, a memória do tempo histórico e do tempo vivido, fazem-se presentes.

Os grupos serão semanais, constando de quatro encontros, com duração de 2 horas e 30 minutos cada.

A condução será feita pela coordenadora e mais dois profissionais, seguindo uma orientação semi-dirigida, com a participação espontânea e consentimento informado. Serão realizadas anotações no decorrer dos encontros, apresentadas aos sujeitos no final de cada reunião para consentimento da manutenção dos registros.

Enquanto as mães permanecerem no grupo, as crianças acompanhantes receberão monitoramento específico. 
No final deste trabalho, havendo interesse das mulheres, serão formados novos grupos onde os temas serão aprofundados de forma contínua.

\section{4 - Descrição do Programa:}

$\mathbf{1}^{\mathbf{0}}$ Encontro: O que aconteceu comigo?

\section{- Objetivos:}

- Propiciar a integração inicial do grupo;

- Apresentar a proposta de trabalho e estabelecer o contrato com o grupo;

- Inserir a discussão sobre a Aids, procurando promover uma reflexão a respeito do impacto da Aids na vida das mulheres.

- Material: revistas, cartolina, cola, tesoura, lápis de cor, canetas hidrocor.

\section{- Descrição do Processo:}

$\underline{1^{\mathrm{a}} \text { Parte: }}$

- Atividade 1: Apresentação* (20’)

A coordenadora entrega para cada participante um cartão de cartolina e pede para que as mulheres colem no cartão um símbolo que as represente (recortado das revistas ou desenhado). Depois, pede que cada participante diga seu nome, apresente seu símbolo, explique porque o escolheu e fale sobre sua expectativa a respeito da participação no grupo.

\footnotetext{
* Atividade extraída de Cruz, E.F. \& Brito, N. Fios da Vida: tecendo o feminino em tempos de Aids. Ministério da Saúde. Coordenação Nacional de DST e Aids. GIV- Grupo de Incentivo à Vida. Disponível em 〈http://www.giv.org.br/fiosaexos.htm〉. Acesso em 24 mai 2003.
} 
A seguir, a coordenadora, que também faz seu símbolo, apresenta-se e acrescenta explicações sobre o funcionamento do grupo e o consentimento informado.

- Atividade 2: Painel* (40’)

Levantamento de temas que fazem parte da vida de uma mulher.

A coordenadora divide as mulheres em grupos. Pede que elaborem um painel falando dos seus sentimentos, dúvidas, dificuldades.

- Intervalo (10’) : suco com biscoitos

$\underline{2^{\mathrm{a}} \text { Parte }}$

- Atividade 3: Apresentação dos Painéis (60’)

A partir da apresentação dos painéis, discute-se os principais aspectos levantados. A coordenadora lança a questão da Aids: Como a Aids poderia entrar/entrou na vida destas mulheres? No final é feita uma síntese dos conteúdos surgidos, promovendo a reflexão sobre o impacto do HIV/Aids na vida das mulheres.

- Avaliação: (10’)

"Conversa de roda", com avaliações do encontro.

$2^{0}$ Encontro: História de Vida

\section{- Objetivos:}

- Identificar, na história de vida, as experiências fragilizadoras e os caminhos encontrados para romper com o determinismo; 
- Construir modos de enfrentamento dos problemas atuais a partir de experiências vividas;

- Oferecer possibilidade de ressignificar as experiências passadas.

- Material: brinquedos (bonecas, panelinhas), revistas cola, tesoura, canetas hidrocor, lápis de cera, papel sulfite, óleo de amêndoas, CD.

\section{- Descrição do Processo:}

\section{$\underline{1}$ a Parte:}

- Atividade 1: Voltando à Infância (30’)

O grupo é organizado em círculo. A coordenadora pede que fechem os olhos e pensem na sua infância. Depois de alguns minutos, a coordenadora coloca vários brinquedos no meio do círculo e solicita que peguem aquele que representa a sua infância. Cada participante é convidado a falar sobre o porque da escolha e o que representa. São discutidos desta foram, os aspectos marcantes da infância de cada uma.

- Atividade 2: Álbum de Família ('30)

É solicitado que recortem figuras das revistas que representem fatos marcantes de suas vidas e confeccionem um álbum de fotografias”. Esta atividade tem como objetivo o desencadeamento de lembranças múltiplas funcionando como espaço de síntese e reconstrução.

- Intervalo (10’) : suco com biscoitos

$\underline{2^{\mathrm{a}} \text { Parte }}$

- Atividade 3: Apresentação do Álbum de Fotografias (30’) 
Cada uma apresenta seu álbum e discute-se coletivamente sobre os principais assuntos levantados.

- Atividade 4: Reflexão sobre auto-cuidado (30’)

A coordenadora pede que sentem no chão e entrega um vidrinho de óleo de amêndoas para cada uma. Convida para massagearem os pés. Enquanto fazem a massagem, conversam sobre o significado do auto-cuidado.

- Avaliação: (10’)

"Conversa de roda", com avaliações do encontro.

$3^{0}$ Encontro: Amar é... Ser mulher é...

\section{- Objetivos:}

- Discutir o amor no plano dos relacionamentos;

- Discutir sobre relações de gênero, mostrando os determinantes históricos, sociais e relacionais na construção do feminino;

- Propiciar espaço para discutir como as representações de gênero interferem na vida destas mulheres;

- Discutir o exercício da sexualidade.

- Material: maquiagem, roupas, acessórios, cartões para pintura, tinta guache, pincéis, giz de cera, $\mathrm{CD}$.

\section{- Descrição do Processo:}

$\underline{1{ }^{a} \text { Parte: }}$ 
- Atividade 1: Viagem* $\left(60^{\prime}\right)$

A coordenadora pede que fechem os olhos e imaginem uma viagem ao país do amor. Vai fazendo perguntas como: Como você está indo para o país do amor? Como é o caminho? Como é o país do amor? Quem está te esperando? Quais são as formas de amor neste país? Como você está se sentindo? Depois de um tempo, pede que abram os olhos e diz: Agora, cada uma de vocês é uma pintora e eu estou encomendando o quadro "O amor e as formas de amar"...

Abre-se uma discussão e cada mulher vai apresentar o seu quadro, falando da sua viagem. A coordenadora ajuda a fazer o fechamento falando sobre a construção sócio-histórica do amor, articulando com os conteúdos surgidos.

- Intervalo (10’) : suco com biscoitos

$\underline{2^{\mathrm{a}} \text { Parte }}$

- Atividade 2: Ser mulher... (10')

A coordenadora lança as perguntas ao grupo: o que é feminino? O que é ser mulher? Como era a vida das mulheres no tempo das avós? Como é hoje?

- Atividade 4: Dramatização (60’)

A coordenadora solicita que formem pequenos grupos e façam uma discussão sobre o cotidiano das mulheres e elaborem uma peça de teatro: Um dia na vida de uma mulher. Para tal, disponibiliza roupas, acessórios, maquiagem...

Cada grupo apresenta sua peça. Após as apresentações são discutidas as situações apresentadas e comparadas com a realidade de cada uma. 
- Avaliação: (10’)

"Conversa de roda", com avaliações do encontro.

$\mathbf{4}^{\mathbf{0}}$ Encontro: Construção de metas.

\section{- Objetivos:}

- Construção de projetos, metas futuras.

- Discutir sobre como torná-las realidade;

- Encerrar o processo de grupo enfatizando o fortalecimento das participantes através da interação em grupo;

- Avaliar o conjunto dos grupos.

- Material: Novelo de lã, cartões com palavras, CD.

\section{- Descrição do Processo:}

$\underline{1^{\mathrm{a}} \text { Parte: }}$

- Atividade 1: Construindo metas (50’)

Com uma música de fundo, pede-se que fechem os olhos e imaginem como gostariam que fosse a sua vida...

O grupo é organizado em círculo. Cada mulher verbaliza um sonho, um desejo e passa o fio para outra pessoa, e assim por diante, até que todas tenham falado, formando uma teia que representa a linha dos limites, mas também a corda da aproximação. 
Discussão das metas: como tornar realidade? O que é preciso? Quais as dificuldades?

- Atividade 2: Avaliação dos Grupos ('30)

A coordenadora entrega para cada mulher um cartão com um desenho geométrico e uma palavra escrita referente aos temas trabalhados no processo dos grupos. Elas devem formar grupos de acordo com as formas geométricas e discutir os temas que as palavras escritas sugerem refletindo sobre o que aprenderam nos grupos sobre o assunto.

Ao retornar para o "grupão", cada mulher apresenta uma frase com a palavra contida no seu cartão referente ao seu aprendizado. Em seguida, cada uma deverá sintetizar a frase em uma palavra. Esta palavra deverá ser repetida cada vez mais alto, ao mesmo tempo em que o grupo vai se comprimindo no meio, até que terminem todas abraçadas.

- Atividade 3: Confraternização

Encerrando o processo dos grupos, será realizado um lanche coletivo, com música, podendo contar com a presença dos filhos. O grupo será fotografado e a foto distribuída, posteriormente, para cada participante.

\section{5 - Avaliação}

A Avaliação final se dará pela síntese sobre o processo de construção de conquistas propostas pelo grupo. 
Após cada sessão, a equipe se reunirá para a discussão e síntese dos resultados obtidos que deverá ser redigida para posterior tabulação e análise dos resultados obtidos.

A análise deste material servirá de base para o aperfeiçoamento do trabalho, além do estabelecimento de rotinas de atendimento e sistematização do conhecimento adquirido, visando criar recursos para a formação e desenvolvimento de pessoal competente diante das exigências psicossociais dos usuários dos serviços de saúde.

Assim, além de se estender às questões da organização da práxis, este trabalho poderá ser reorientado para a capacitação do profissional de saúde no sentido de poder sistematizar e aproveitar a aprendizagem informal, acumulada pela experiência no trato com paciente.

Sendo assim, este projeto busca a garantia de um espaço de reflexão que possibilite aos seus participantes, seja o paciente ou o profissional de saúde, rever, de forma compartilhada, seus papéis e expectativas, auxiliando na prevenção ou na construção de uma convivência mais positiva com a Aids e promovendo uma melhora na qualidade de vida e na luta pela própria cidadania.

\section{Referências Bibliográficas}

AYRES, J.R.C.M. Repensando Conceitos e Práticas em Saúde Pública.In: PARKER, R.; TERTO JR., T. (Org.). Aprimorando o debate: respostas sociais frente à Aids. Rio de Janeiro: ABIA, 2002. p.12-19.

BASTOS, F. I. A feminização da AIDS no Brasil: determinantes estruturais e alternativas de enfrentamento. C. ABIA: Saúde Sexual e Reprodutiva, Rio de Janeiro, $\mathrm{n}^{\mathrm{o}}$ 03, 2000. 
CAMPOS, R. Em A nova fórmula do casamento. Revista Viver. São Paulo: Segmento, ano VII, $n^{\circ} 87$, abril de 2000.

COSTA, J. F., Sem fraude, nem favor: estudos sobre o amor romântico. Rio de Janeiro: 1999.

CRUZ, E.F. \& Brito, N. Fios da Vida: tecendo o feminino em tempos de Aids. Ministério da Saúde. Coordenação Nacional de DST e Aids. GIV- Grupo de Incentivo à Vida. Disponível em <http://www.giv.org.br/fiosaexos.htm>. Acesso em 24 mai 2003.

FERNÁNDEZ, A. M., La mujer de la ilusión: pactos y contratos entre hombres y mujeres. Buenos Aires: Paidos, 1994.

FIGUEIREDO, M.A.C.; Estudo de Representações sobre Aids em pacientes, para a formação profissional visando grupos de suporte para pessoas contaminadas pelo HIV, sintomáticas ou não. Jornal Brasileiro de Aids, 1(5), out, nov/dez, pág.22-31, 2000 .

FISCHER, I. R.; MARQUES, F. Gênero e exclusão social. Disponível em http://www.fundaj.gov.br/tpd/113.html. Acesso em: 06 de setembro de 2001.

GIDDENS, Em A transformação da intimidade: sexualidade, amor e erotismo nas sociedades modernas. São Paulo: Editora da Universidade Estadual Paulista, 1993.

GUERRIERO, In.; AYRES, J.R.C.M.; HEARST, N. Masculinidade e vulnerabilidade ao HIV de homens heterossexuais, São Paulo, SP. Rev. Saúde Pública, 2002; 36 (4 Supl): 50-60.

KORNBLIT, A. L., SIDA: entre el cuidado y el riesgo. Buenos Aires: Alianza, 2000.

LOBATO, J. P., Amor, desejo e escolha. Coleção Gênero: Rio de Janeiro: Record/Rosa dos Tempos, 1997.

MONTEIRO, S. Prevenção e reprodução no contexto do HIV/AIDS: comentários. In: Maksud et al (Orgs.). Conjugalidade e Aids: a questão da sorodiscordância e os serviços de saúde. Rio de Janeiro: ABIA, 2002; p. 73-76.

PAIVA, V. Sem mágicas soluções: a prevenção ao HIVe à Aids como um processo de "emancipação psicossocial” In: PARKER, R. \& TERTO JR., T. (Org.). Aprimorando o debate: respostas sociais frente à Aids. Rio de Janeiro: ABIA, 2002. p.20-26

PARKER, R.; CAMARGO JR., K. R. Pobreza e HIV/AIDS: aspectos antropológicos e sociológicos. Cadernos de Saúde Pública, Rio de Janeiro, 16(Sup. 1): 89-102, 2000 . 
REIS, M. M. F., Mulher: produto com data de validade. São Paulo: O nome da Rosa, 2002.

REZENDE, Em L. M., Saúde: dialética do pensar e do fazer. São Paulo: Cortez, 1986.

SALDANHA, A.A.W.; FIGUEIREDO, M.A.C. A vulnerabilidade feminina ao HIV. In: SOCIEDADE BRASILEIRA DE PSICOLOGIA. Resumos de Comunicações Científicas. XXXI Reunião Anual de Psicologia. Rio de Janeiro, RJ: SBP, 2001; p. 289.

SALDANHA, A.A.W.; FIGUEIREDO, M.A.C. Gênero, Relações Afetivas e Aids no Cotidiano da Mulher Soropositiva. AidsCongress.net, AidsPortugal.com. Sidanet Associação Lusófona, Portugal, (10p), 2002.

SEFFNER,F. Prevenção à Aids: uma ação político-pedagógica. In: PARKER, R. \& TERTO JR., T. (Org.). Aprimorando o debate: respostas sociais frente à Aids. Rio de Janeiro: ABIA, 2002. p.28-35.

SPINK, M.J.P.; MEDRADO, B. Produção de sentidos no cotidiano:uma abordagem teórico-metodológica para análise das práticas discursivas. In: SPINK, M.J.P. (Org.)Práticas discursivas e produção de sentidos no cotidiano: aproximações teóricas e metodológicas. São Paulo: Cortez, p. 41-62, 2000. 
ANEXOS 


\title{
SÍNTESE DA HISTÓRIA DE VIDA 01
}

\author{
"Se eu tiver que pegar, eu peguei naquela noite. Não \\ importa, eu vou ficar com você para o resto da \\ minha vida, agora vai ser eu e você. Você olha por \\ mim e eu olho por você."
}

Tive um namorado que morreu de AIDS. Eu não culpo ele, porque eu gostava dele. Sabe, todo mundo, às vezes, comentava, mas ele nunca apresentou nada, parecia uma pessoa normal. A mãe dele também falava que não, que isso eram os outros que falava. Então eu acreditei nele. Acreditei na família dele. Mas era verdade o que os outros falavam. Quando minha mãe ficou sabendo, fez eu largar dele. Aí nós largamos.

Foi quando eu engravidei. E eu não falei pros médicos que tavam fazendo o meu pré-natal. Eu fiquei com medo e guardei pra mim mesma, não falei pra ninguém.Então eu acho que pus a vida dele em risco. Se eu tivesse feito tratamento, ele não teria nascido com isso. Eu acho que eu teria evitado. Mas ele nasceu, pra mim foi duro. E aí eu fiquei sabendo. Eu ficava o dia inteiro lá no hospital. Ele ficou mais no hospital do que em casa mesmo. Ele morreu, ele tava com quatro meses.

Eu não queria ter outro relacionamento porque eu tinha medo de falar pra ele que eu tinha, né? Porque todo mundo falava que o meu primeiro tinha morrido disso, todo mundo falava que eu tinha. Então, eu falei pra ele: "Eu não tenho, só que eu não quero saber de homem na minha vida". E ele disse; "Eu não tenho medo. Por mim eu não tenho medo de estar com você, de pegar, porque eu gosto de você". Eu falei: “ Não, mas eu não quero. E se eu tiver? Aí vou passar pra você? Uma pessoa inocente que não tem nada a ver com isso? Pra que você quer pegar isso?" Mas aí a gente começou a namorar usando preservativo. Aí, aconteceu de um dia a camisinha furar e daí, de lá pra cá, ele falou: "Ah! Se tiver que pegar, eu peguei naquela noite. Não importa, eu vou ficar com você para o resto da minha vida, agora vai ser eu e você. Você olha por mim e eu olho por você.” E estamos aí até hoje.

Aí, da menina eu fiz tratamento e, graças a Deus, negativou. Minha filha é uma pessoa linda e perfeita. Pra mim, foi o filho que eu perdi, só que Deus abençoou. Eu quero que esse aqui também, eu faço tudo para que nasça com saúde.

O sujeito 1 tem 21 anos. Estudou até a $5^{\text {a }}$ série do ensino fundamental. Está casada consensualmente - pela segunda vez - há 4 anos. Se encontra grávida pela terceira vez. O primeiro filho (do primeiro relacionamento) morreu aos 4 meses de vida, soropositivo. Tem uma filha de 2 anos, do segundo marido, soronegativa. $\mathrm{O}$ marido recusa-se a fazer o teste.

Foi contaminada pelo marido anterior. Terminaram o relacionamento ao saber que ele estava com Aids, tendo morrido logo depois. Confirmou o diagnóstico no nascimento do $1^{\circ}$ filho. 


\title{
SÍNTESE DA HISTÓRIA DE VIDA 02
}

\author{
"Eu, de uma certa forma, com todos os meus problemas, \\ eu sou feliz. Não posso dizer que não. Deus está me \\ dando uma graça muito grande que é ser mãe."
}

Meu pai era um bêbado incorrigível. Minha mãe largou do meu pai.

Conheci meu marido no trabalho, que eu trabalhei com ele, era cobradora. Ele também é um cobrador. Tinha uns 18 anos. Ele tinha 26, bem mais maduro. Eu tinha acabado com um namorado fixo, eu tinha feito um aborto, tava meia esquisita, deprimida, sabe? Eu descobri que ele (namorado anterior) tinha... que ele gostava de um lado e do outro também, dos dois lados. E era uma coisa que, na época, eu não aceitava, tipo assim, é difícil você aceitar que uma pessoa goste dos dois sexos. Não é como hoje... Daí, eu já vinha sofrendo estas desilusões, eu namorava com ele há 8 meses.

Mas, voltando ao assunto, ele foi me procurar e a gente começou a namorar. Ai não se separou mais. A gente começou a morar juntos. Depois de um ano e meio que a gente estava morando juntos, ele começou com as drogas. A gente separou umas cinco vezes. Aí ele começou a andar muito, chegar de madrugada, eu comecei a ficar meio assim. Mas, fiz uma ameaça a ele, tudo, mudamos de ramo de serviço, compramos a pensão, nós começamos a tocar tudo, ele mudou um pouco. Só que ele mudou tarde, porque ele já estava afetado. E eu não sabia. E eu sei que não tinha porque eu fiz todos os exames pra ter minha primeira filha, e eu não tinha nada.

Eu nunca imaginei que ele pudesse ir lá pra rua enquanto eu trabalhava. Quando minha filha fez 6 meses eu comecei a descobrir estes gânglios. Os médicos do convênio não diagnosticaram nada. Aí eu deixei, fui deixando. Aí fiquei grávida e...descobri o problema. Eu gritava pra ele: "como isso aconteceu? Você quer me contar como aconteceu? Você me deve uma explicação que eu sei o que eu fiz."

Tudo o que eu quis na minha vida, foi ter minhas filhas. Levei treze anos pra ter um filho. E, nossa, tenho um orgulho da minha primeira filha. A segunda, olhe que foi uma das crianças que eu mais me revoltei quando eu descobri que tinha o HIV, que eu não queria ela, tadinha. Comecei a usar drogas, fumar, beber, sabe, extravagância, pensei até em me suicidar. Eu pensava: " Meu Deus, eu acho que não posso ter esta filha, tadinha. Um dia, o que posso dizer pra ela se ela não negativar? Filha, você teve isso porque eu admiti que seu pai fizesse as artes dele. Porque eu admiti. Não por minha culpa, mas eu vou fazer o que? Dá pra entender o desespero que fiquei quando fiquei grávida desse? Ta certo que a culpa não é sua, você fala: " a culpa não é minha". Como dizem, fácil é falar que é só dele, mas também é minha, porque eu aceitei ele.

Hoje ele ta um pouco melhor. As drogas que eram maiores ele já diminuiu bastante. Não ta cometendo tantos excessos como ele cometia. Já não ta mais aquela pessoa que fazia aquelas atividades rotineiras, chegava de madrugada. Ele ta com 
uma vida, assim, sossegada. O certo seria tomar medicamento, mas é aquela história, se você enfiar na cabeça que você está realmente com um problema, você vai ta, né?

Não vou negar que hoje, quando ele pisa o pé fora de casa, vai embora pra algum lugar, eu já fico assim... tem vezes que até eu pego minhas meninas e digo: "vamos dar uma volta". E saio só para vigiar, ver o que ele ta aprontando, o que ta fazendo.

De uma certa forma, ele condenou a família, poderia ter pensado um pouquinho mais. Porque ta certo que, hoje ele é bom, mas a culpa foi dele.

$\mathrm{Eu}$, de uma certa forma, com todos os meus problemas, eu sou feliz. Não posso dizer que não. Deus está me dando uma graça muito grande que é ser mãe.

O sujeito 02 tem 33 anos. Estudou até a $7^{\text {a }}$ série do ensino fundamental. Atualmente, administra uma pensão própria. É casada legalmente há 9 anos. Encontra-se no $6^{\circ}$ mês de sua terceira gestação. Tem duas meninas, uma de dois anos, soronegativo, e outra com 11 meses, ainda em seguimento.

Descobriu seu status soropositivo no pré-natal da segunda filha. 


\title{
SÍNTESE DA HISTÓRIA DE VIDA 03
}

\author{
"Se existe amor, você tenta compreender, você tenta \\ achar um lado, um motivo para o que aconteceu."
}

Minha mãe fala que até os 9 anos de idade, eu sempre tive muitos problemas, tive problemas de coração, fiz cirurgia, bronquite, problema de coluna, tive tudo na minha vida, tudo.

Acho que não aproveitei minha juventude. Porque eu conheci meu marido, eu tinha 14 anos. Eu tinha que trabalhar. Era balconista. Trabalhei só 6 meses. Aí devido a um problema de coluna, eu tive que parar. Aí eu ia fazer cirurgia de coluna, tinha até marcado. Aí foi quando eu conheci ele, fiquei grávida, tive a criança, casei...

A minha mãe, como sempre revoltada, ficou muito braba, porque, quando eu namorava, ela dava força prá mim casar com ele, mesmo tendo 14 anos. Depois que eu tive o menino, ela queria que eu largasse dele. Ela cismou que ele mexia com drogas. Até hoje ela fala isso. E até hoje eu falo pra ela que não mexe, eu vivo com ele há 10 anos, se ele mexesse não teria motivo pra esconder de mim. Eu namorei com ele 1 anos e meio. Conheci ele.

Meu pai, eu não sei se poderia julgar ele por alguma coisa, assim, não sei se foi culpa dele eu ter a juventude que tive. Porque ele é alcoólatra. Eu tinha 14 anos e ele bebia muito. E ele era de beber e arrumar confusão. E eu detestava isso. Então achei uma forma de me casar aos 14 anos. Ia ser bom pra mim sair daquela coisa ruim lá dentro.

$\mathrm{Na}$ época, quando eu recebi o resultado (no parto do primeiro filho), eu não liguei, não. Eu não dei muita importância. Eu não acreditei. Ele (o filho) teve acompanhamento até 4 anos e nunca deu, sempre negativo. O que me fez acreditar mais ainda que não era nada, porque ele tava bem, né? Aí, eu comecei, como sempre, a ficar doente outra vez. Eu achava que era o problema de criança. E ele também, soube junto comigo. Ele acredita que ele não tem nada. Ele fala que não tem nada. Ele não acredita que tenha, mas ele me dá apoio, ele quer que eu me cuide, não quer que eu fique doente.

O pior de tudo, foi a minha mãe saber primeiro, porque eu acho que ela era a última pessoa a poder saber, né? E ela foi a primeira. Porque o médico não me comunicou, não comunicou ninguém que ia fazer o exame. Eu achei errado isso, porque eu acho que é essencial você ter a autorização do paciente para fazer o exame. E tem que dar a notícia com autorização do paciente. Não, ele fez exame sem minha autorização, sem falar nada comigo e ainda foi direto na minha mãe. Ele queria que minha mãe me desse, me falasse. Era médico particular, né? E o convênio não cobria. Então, ele queria um meio de sair fora, né?

É difícil aceitar, né? Mas eu não tenho outras opções pra mim... que pra mim brigar com ele, não vai dar certo, pra viver brigado, porque eu tenho esse problema. Se eu largar dele, também não tenho pra onde ir, porque minha mãe, quando ela soube, ela foi a que menos deu apoio. 
Se eu não gostasse dele, eu não estaria com ele, eu não aceitaria, porque tem muita gente, á onde eu trato, tem muita mulher revoltada, descontrolada com o marido. Só que isso, eu acho que acontece quando não existe amor. Se existe amor, você tenta compreender, você tenta achar um lado, um motivo pra o que aconteceu. Eu acho que o que aconteceu pode ser uma falha dele, pode acontecer com qualquer um, porque tá arriscado a acontecer.

O sujeito 3 tem 26 anos, é casada legalmente há 10 anos e tem dois filhos, de 10 e 9 anos, ambos soronegativos.

Soube ser soropositiva há 9 anos, no parto do segundo filho, mas não acreditou, embora tenha feito o seguimento do bebê até os médicos confirmarem ser soronegativo. Três anos após, apresentou um quadro de pneumonia e, então, foram feitos novos exames onde foi novamente constatado infecção pelo HIV.

Embora acredite ter sido contaminada por via sexual, o marido, seu único parceiro sexual, se recusa a fazer o teste, alegando não ter nada. Também se recusa a falar sobre o assunto. 


\title{
SÍNTESE DA HISTÓRIA DE VIDA 04
}

\author{
"Aí ele falou: 'Por que você não quer saber?' E eu disse: \\ 'porque do mesmo jeito que você tá, eu também tô'. \\ Mas, nunca, assim, com a palavra direta, AIDS. Nunca, \\ nunca, nunca. Aí, do jeito que tava, ficou."
}

A minha vida é ruim. Só não é ruim, porque eu não quero. Desde que eu me conheço por gente, minha mãe e meu pai brigavam muito. Aí, separaram e minha mãe arrumou outro homem. Gente preferiu ficar com o meu pai. Acho que eu devia ter uns 8 anos. Ela nunca foi de dar atenção pra nós. Desde que a gente era pequenininha, sempre meu pai que estava ali. Só que ela era meio desviado por causa da cachaça, que ele bebia muito. E ela arrumou esse homem que vivia xingando nós. Não querendo que nós entrasse na casa dela.

Comecei a namorar com 14 anos. Ele foi meu primeiro parceiro. Aí, foi quando eu fiquei grávida, com 14 anos. Aí, veio aquela confusão, meu pai queria que nós casasse. Aí, tive que ir morar com ele. Tive a criança, que morreu em março. Aí, quando deu setembro, ele começou a ficar doente e quando foi em novembro, ele morreu. Passou uma semana e eu fiz o exame e deu que eu tinha HIV.

Quando eu recebi este diagnóstico, eu era muito criança, tinha 15 anos. Então, você não pensa. Porque eu nem sabia que existia isso, eu não tinha informação. Quando eu completei 20 anos é que eu comecei a ver a coisa direito. Mas aí, eu já tava acostumada, porque eu ia no médico todo mês.

Quando eu tava com 16 anos, eu tava sozinha de novo e aí voltei a morar com o meu pai. Só que sem ninguém saber do problema, só minha irmã sabia de tudo. Aí, meu pai começou a beber demais, ficava meio malucão e acabamos sendo despejados de casa.

Aí, meu pai sumiu. Nós era tudo de menor. Mas aí nós chegava lá (na casa da mãe) e ele não deixava tomar banho, nós não podia comer, ele tacava as panelas na rua. Nós ia trabalhar morrendo de fome. E ela sempre defendendo ele. (...) Aí eu disse que não agüentava mais e resolvemos ir embora. Tinha uma casa velha, abandonada, e fomos morar nessa casa. Ela (a irmã) trabalhava e nós dividia tudo. E ela sabendo do meu problema. Eu ia no médico de pé mesmo, chegava lá toda suja (...)Aí, eu conheci o C., fiz amizade com ele. Aí minha mãe largou dele e disse: “ vem morar aqui”. Aí minha irmã falou: "sabe o que eu vou fazer, eu to namorando o E. e vou morar lá na casa da mãe dele, que eu não agüento mais". Ela foi morar com a sogra dela. Aí, eu voltei a morar com a minha mãe. Não tinha jeito. E aí sabe o que ela fez? O que ela teve a coragem de fazer? Ela mudou e colocou toda a minha roupa na calçada, levou todas as coisas dela e me deixou. E ainda falou para o C.: "Agora, você pega as coisas dela e leva pra tua casa". Eu cheguei do serviço e ele me disse, antes de eu entrar: "Vem cá..." Pra mim foi o fim. Acabou. Aí eu fui morar com ele e to até hoje.

Eu já sabia que ele tinha. Foi uma coisa meio esquisito de contar. Você sabe quando ele quer falar as coisas e não fala? Só que eu não queria escutar. Ele falou assim: "Olha, tem duas coisas que eu quero te contar, a primeira é ruim e a segunda 
mais ou menos. Entoa, antes da gente começar a ter uma relação mais séria, já vou te contar. Ó, eu tenho..." E eu falei: Ah! Nem fala nada, deixa pra dizer que é melhor". Aí, eu cortei o assunto no meio do caminho mesmo. Eu não quis saber. Aí, ele falou: "Por que você não quer saber?" E eu disse: "Porque do mesmo jeito que você tá, eu também to." Mas nunca assim, com a palavra direta, AIDS. Nunca, nunca, nunca. Aí, do jeito que tava, ficou.

Foi quando eu fiquei grávida da minha menina. Aí, ele ficou meio assim. "Como que vai ser agora? Você ta grávida. E o neném? Como é que vai ser? Eu tenho medo, vai que morre..." Aí, eu falei: "Não, hoje em dia tem mais recurso." Aì comecei a fazer o tratamento certinho e ela nasceu, não tem nada. Só que é assim, ele não comenta. Ele pergunta: Foi ao médico? Tomou o remédio? Mais nada.

O sujeito 04 está com 22 anos, é casada consensualmente há 6 anos. O marido também é soropositivo. Tem dois filhos, uma menina de 5 anos e um menino de 2 anos, ambos soronegativos. Encontra-se no $6^{\circ}$ mês de gestação.

Tem conhecimento de sua soropositividade há 7 anos, não apresentando nenhum sintoma. Atualmente, trabalha em uma ONG de prevenção à AIDS. 


\title{
SÍNTESE DA HISTÓRIA DE VIDA 05
}

\author{
"Logo no começo, fiquei bem chocada, mas depois \\ eu fui indo...cada um tem o que passar, né? Se esse \\ foi o meu destino..."
}

Desde que eu nasci, tem muita coisa boa... A infância foi normal, brincando muito... eu era a mais mimada da família. A adolescência também foi boa.muitas amizades, muitos amigos.

Tive meu primeiro relacionamento com 16 anos. No primeiro relacionamento, fiquei grávida. Daí, nós fugimos. ...era uma vida boa. Ele não deixou mudar em nada por causa dele, não me prendeu, saia para passear comigo. Foram 6 anos, estava dando certo. Mas ele morreu. Acidente de carro. Foi difícil, foi pesado. Eu sinto até hoje. Gostava muito dele. Mas a gente esquece, né? Tudo a gente tem que esquecer. Não tem jeito pra isso.

Quando ele faleceu, eu estava grávida do neném, o mais novinho. Acho que depois de um ano e meio, que eu conheci esse aí. Acho que eu ficava muito sozinha, a solidão batia mesmo, com saudade. É ruim viver sozinha. Então, ao invés de ficar batendo cabeça, ficar com um, ficar com outro, melhor casar. Logo no começo, conheci ele, ficamos namorando 6 meses, depois fomos viver juntos. Ficamos até agora, até quando Deus separar nós dois. Não é igual ao primeiro. Aquele lá era o primeiro amor, esse aí já é o segundo amor. Não é igual, é um pouco diferente.

Um dia, a minha sogra ligou lá em casa e falou: “Ah! A mulher do M. ta doente..." Ele já tava começando, sabe, tosse, dor... foi onde eu fiquei pensando. Depois minha sogra ficou sabendo e falou pra ele que ela tava com AIDS. Daí eu fiquei com mais certeza, porque, se ela tava, por que ele também não? Só que eu não toquei no assunto, fiquei quieta. E ele também, não comentou nada, ficou quieto, porque já faz 6 anos que eles tão separados. Aí, ele falou assim: "Ah! Não pode ter sido nós dois. Não pode ter sido daquilo que eu estou com isso. Talvez ela pegou de outra pessoa." Aí, eu via muito os outros falar sobre isso aí, eu via na televisão. Aí, eu ficava quieta pra não falar nada pra ele. Mas eu pensei: poxa, eu vejo gente falar que isso aí fica no corpo, pra se manifestar demora muito, vai dependendo do organismo da pessoa, ela demora 5,6, até 10 anos... Aí, depois, o médico falou que ele tava contaminado.

$\mathrm{Eu}$ fui junto na consulta. O médico falou assim: "É, foi bom que você veio..." Aí, eu pensei: seja lá o que Deus quiser. Se for o que nós tiver pensando... O médico falou assim: "Eu não tenho certeza porque isso aqui foi passado por telefone. Não tenho certeza, não to garantindo. Então, você vai pra lá (HC), que nós vamos passar pra fazer um novo teste." Aí marcou pra mim, eu vim, fiz um teste rápido, na hora já saiu. Já entrei em desespero. Aí o médico falou que já não tinha tanto o risco dele (o neném) ter o vírus. Mas, eu fiquei bem ruim mesmo. 
Eu fico perguntando: como é que pode acontecer uma coisa dessas e até agora não ter cura? Tem hora que eu paro e penso assim... Logo no começo, fiquei bem chocada, mas depois eu fui indo, cada um tem o que passar, né?Se esse foi o meu destino...

Eu procuro sentir alegria, eu não quero tristeza. De vez em quando, a tristeza vem, a tristeza bate. Pega na angustia, tristeza, medo... medo de morrer, isso eu não tenho. Mas é um medo, assim, de deixar os meus filhos pequenos ainda. Vou me cuidar até poder deixar os meus filhos, pelo menos a minha filha mais velha, mais grande, pra cuidar dos irmãos pequenos.

O sujeito 05 está com 26 anos e grávida do $5^{\circ}$ filho - o $1^{\circ}$ do segundo casamento. Soube ser soropositiva no primeiro mês desta gestação, ocasião em que seu marido ficou doente e foi diagnosticado AIDS. No momento encontra-se internado na UETDI. 


\title{
SÍNTESE DA HISTÓRIA DE VIDA 06
}

\author{
"Por que isso foi acontecer comigo? Eu ainda levei o \\ vírus pros meus filhos e posso levar pro meu marido..."
}

$\mathrm{Na}$ verdade, eu não tive infância, não era menina de ficar brincando. Eu sempre fui, assim, meio secona, ficava mais nos cantos, era sozinha, isolada dos outros. Ficava com a minha família, minha mãe, minhas irmãs, meu pai. Pra você ver, eu tive a minha primeira relação com 13 anos. Eu nunca me senti criança, queria ser mais adulta. Com 10 anos eu ia à discoteca, saia, gostava de sair com mulheres mais velhas, casadas. Eu sou a mais velha de 5 irmãos.

A minha adolescência foi boa, saia bastante, gostava de discoteca. Aí, depois, entrei na igreja e fui mudando. Bagunçar, bagunçar, eu não baguncei, não. Aí, com 19 anos, eu fiquei grávida e casei.

Eu namorei ele quando tinha 12 anos. Ele morava em frente à minha casa, mas foi um namorinho de criança. Eu não queria porque era muito nova, meu pai também não queria. Aí, ele foi embora e, depois de 5 anos, a gente se encontrou de novo, aí a gente começou a namorar e depois casou.

Quando eu fiquei sabendo disso, foi um choque. Eu pensei que tinha pegado dele, porque ele já tinha falado pra mim que tinha uns amigos que se drogam. Esses moços só aprontam... Quando ele era solteiro, ele falava pra mim que usava drogas. Uma vez, conversando sobre isso, antes de eu ficar grávida, ele falou pra mim que tinha medo por causa de algum namoro antigo, porque ele já tinha se arriscado muito. Aí, eu já pensei que tinha pegado dele. Porque, uns tempos atrás, eu peguei uma alergia por baixo, me deu coceira e eu não tava tempo relação com ninguém. Aí, eu fui no médico e o médico me pediu uma porção de exames, um monte de coisas. E nos exames não deu nada. Pra mim, se eu fizesse qualquer exame de sangue, dava. Aí, eu tava com isso na cabeça, e falei: "Olha, eu tenho certeza que eu peguei de você porque eu não tenho nada. Porque o médico fez uma porção de exames em mim e não deu nada."

Então, ele ficou desesperado, foi uma choradeira. Então, eu disse pra ele: "Você faz o exame, porque a gente não sabe." Aí, ele foi no pronto-socorro, fui eu e ele. Aí, deu negativo. Aí, depois ele veio na consulta e deu negativo de novo. Aí, só o meu deu positivo.

Aí, eu queria largar dele, não queria mais ficar com ele. Aí, ele pegou e disse que ia continuar.

Por que isso foi acontecer comigo? Eu ainda levei o vírus pros meus filhos e posso levar pro meu marido...

O sujeito 06 tem 22 anos, é casada legalmente há 3 anos e tem dois filhos, uma menina de 1 ano e 8 meses e um menino de 9 meses, ambos soropositivos, mas ainda em seguimento.

Descobriu ser soropositiva ao iniciar o pré-natal do $1^{\mathbf{o}}$ filho. Acredita ter sido infectada pelo parceiro anterior, visto que seu marido é soronegativo. 


\title{
SÍNTESE DA HISTÓRIA DE VIDA 07
}

\author{
"Na hora que a enfermeira me falou, ele disse que \\ já fazia 8 anos que ele fez um teste e que ele tinha. \\ E eu não sabia.
}

Nasci no Mato Grosso, minha mãe tinha muitos filhos, então ela me deu pra uma mulher criar. A mulher me criou até a idade de 16 anos. Aí, o vizinho da casa da frente da gente, me estuprou. Aí, eu não gostei, fui trabalhar e morar no emprego, depois vim morar aqui, em R. P., na casa de uma patroa. Aí, conheci ele (o exmarido). Conheci ele numa discoteca, a gente começou a namorar. Aí, ele disse que queria juntar comigo. Aí, eu juntei com ele. Só que eu não sabia que ele tinha isso. Nós fomos morar com a mãe dele.

Aí, tive o meu primeiro filho, depois tive outro menino, até que tive esse que o médico falou. Mas, por ele me falar, mesmo, ele nunca ia me falar. Na hora que a enfermeira me falou, ele disse que já fazia 8 anos que ele fez um teste e que ele tinha. E eu não sabia. Eu fiquei com muita raiva, mas, fazer o que? Matar ele eu não posso, vou fazer o que?

Aí, nos separamos e eu fiquei morando com a minha sogra. Ela me trata muito bem. O único problema é que ela quer dar esse neném (encontra-se gestante), que fala que eu não tenho como criar, que vou passar aperto. Eu não quero, porque eu já to criando os meus três, uma a mais, um a menos...

Esse outro (o pai do bebê), eu conheci ele lá no serviço que eu trabalhava. Eu trabalho assim, olho carro. Aí, ele ficou comigo. Eu pedi pra ele usar camisinha porque eu não posso ficar transando sem camisinha, tudo. Ele não quis. Aí ele ficou comigo, fez um filho e depois, no outro dia, não apareceu mais. Eu dei o endereço da minha casa pra ele, mas ele não procura, não procura saber como eu to passando.

Hoje, a gente conversa (com o ex-marido), tudo, ele me ajuda como pode, dá de tudo pros filhos dele. Agora, assim, ele me apóia também nessa gravidez, fala também que não é pra dar, que ele ajuda no que puder. Ele me apóia. Eu acho que ele se sente culpado, por isso ele é bonzinho.

O sujeito 07 tem 26 anos, estudou apenas a $1^{\text {a }}$ série do ensino fundamental e trabalha como vigia de carros (flanelinha). É católica, assiste missa todos os domingos. Está separada há 6 anos, tem três filhos: dois meninos de 9 e 7 anos, e uma menina de 6 anos, a única soropositiva. No momento, encontra-se gestante, fruto de um relacionamento ocasional. Ainda mora com a ex-sogra, que lhe ajuda a cuidar das crianças.

Soube ser soropositiva há 6 anos, no pré-natal do $3^{\circ}$ filho. O marido, naquela ocasião, admitiu já ter conhecimento de sua soropositividade. 


\title{
SÍNTESE DA HISTÓRIA DE VIDA 08
}

\author{
"Eu nunca usei drogas, nunca andei com vários \\ homens, sempre tive o maior cuidado. Fazia 8 anos \\ que nós estava, bem dizer, juntos, eu não ia ter. (...) \\ nada mais é a mesma coisa..."
}

A minha infância foi boa, mas não lembro de nada pra contar.

Minha mãe e meu pai se separaram cedo e fui embora pra São Paulo, morar com um irmão. Eu comecei a não me dar bem com a minha cunhada e arrumei um serviço pra morar. Aí, eu vivia muito bem, eu era babá, ganhava bem, tinha uma vida boa. Eu tinha 17, 18 anos.

Aí, um dia, minha avó escreveu pra mim, porque meus irmãos - nós somos 12 filhos - estavam demais e nem minha mãe, nem meu pai, tomavam uma atitude. Meu irmão, mesmo, devido a esta separação, chegou até a entrar na droga, no roubo, porque nem meu pai quis criar, nem a minha mãe. Aí, o que eles aprendeu foi na rua. Aí, eu voltei, deixei tudo e vim cuidar deles. Eles eram mais novos e eu vim... assumi o controle da casa, comecei a trabalhar.

Esse moço, eu comecei a namorar com ele, tinha 13 anos e já gostava dele. Não é o meu marido. Daí, nós namoramos muito tempo, acho que uns três anos. Foi quando eu fui pra São Paulo. Meu irmão não queria, não aceitava. Mas eu gostava e continuei gostando. E voltei pra ver ele. Ele gostava de mim. Só que ele sabia, a família dele inteirinha sabia. E não me falou. Ele tentou várias vezes me falar. Agora que ele morreu que você sabe, né? Que ele tentou. Várias vezes ele perguntava assim: "Se você descobrisse algum dia que tinha AIDS, o que faria?" Aí eu falava: "Ah! Eu me mato, Deus me livre!" Eu nunca usei drogas, nunca andei com vários homens, sempre tive o maior cuidado. Fazia 8 anos que nós estava, bem dizer, juntos, eu não ia ter. Aí ele fez um "olá" e ficou preso. Aí eu descobri. Aí, eu fui lá e perguntei e ele disse que era. Aí eu fiz um exame. Eu tinha uns 18, 19 anos. Eu fiz e deu negativo.

Aí, eu nem me preocupei mais, certa que eu era negativa. Eu falei pra ele que fiquei muito triste por ele ter escondido. E ele falou que foi porque me amava demais e que se falasse, eu não ia ficar com ele. Eu disse que ele não podia fazer isso, que não é porque ele vai pro inferno, que vai me levar junto, né? Ele tinha que ter sentado comigo e conversado. Ele sabia, então, tinha que ter me falado. E eu gostava dele. Tanto é que fiquei com ele ainda, sabendo. Mas, depois disso, foi acabando o amor, não sei se pelo fato de ter feito o exame e ter dado negativo. Quando ele morreu, eu já tava com o meu marido.

Ele era o namorado da minha irmã, mas ele sempre gostou de mim. Eu não gostava dele. Aí, um dia começamos a conversar e eu comecei a gostar dele e nunca mais soltei dele.

Eu venho de uma família muito humilde, a dele não, é tudo bem de vida. Então, só depois de muito tempo a gente ficou junto, porque a família dele não 
queria. E eu também não queria. Mas ele... E eu não tava grávida quando fui morar com ele. Engravidei depois de 2 anos e 7 meses.

Aí, na gravidez, tudo foi normal. Bem depois, quando eu já tava com 23 anos, eu tive meningite. No hospital, o médico falou que tava desconfiado, mas eu tinha o meu HIV negativo. Mas, ele não falou pra mim, chamou o meu marido e falou pra ele. Aí, meu marido me falou. Ele não queria me falar, mas foi assim: foi na hora da visita, ao o médico chegou na porta e chamou ele. Meu pai, naquele dia, tava lá. Aí ele veio... sabe quando a pessoa ta com dificuldade de falar uma coisa? Aí ele me levou no banheiro e eu não agüentei e disse pra ele: "Pode falar tudo o que o médico falou." E ele: "Ele não falou nada". Eu insisti e ele falou. Falou que tinha dado positivo os meus exames. Eu quase demoli o banheiro. Aí... nada mais é a mesma coisa, porque parece aquela coisa, onde você vai tem sempre alguém que vai tocar nesse assunto. Tem pessoas que você tem certeza que não sabe, que você nunca viu. Mas tem outras que parece que fala porque tem medo de pegar e ta sempre lembrando a gente.

O sujeito 08 está com 25 anos. Estudou até a $6^{a}$ série do curso fundamental e trabalha como faxineira. Está casada consensualmente há 7 anos, tem uma filha de 3 anos, soronegativa, e, está grávida de 13 semanas. Seu marido é soronegativo.

Há dois anos teve conhecimento do diagnóstico. É sintomática, já teve meningite, pneumonia e, atualmente, está com suspeita de tuberculose. Deveria estar fazendo uso do coquetel de medicamentos, mas parou por conta própria. Está dando inicio ao acompanhamento pré-natal. 


\title{
SÍNTESE DA HISTÓRIA DE VIDA 09
}

\author{
Eu destruí toda a minha vida, eu destruí tudo o que \\ eu tinha. (...) Acho que, o que ele fez, não tem perdão.
}

Na minha infância, meu pai levava a gente pra roça. A gente trabalhava e se divertia muito. Eram 10 irmãos. Mas, um irmão morreu, também com esse vírus.

Meus irmãos brigavam muito comigo, porque meus pais eram adotivos. Minha mãe cuidava de três sobrinhas e eu achava que sempre a atenção dela era mais pra elas. E eu apanhava muito por causa delas. Era a culpada de tudo.

Meu primeiro namorado foi o rapaz da esquina. Eu não lembro quantos anos tinha, eu mal tinha me formado. Eu conheci ele e fui morar com ele. Achei que minha vida ia melhorar, mas só piorou as coisas. Eu lembro que sofri muito nas mãos dele, ele me batia, tudo. Minha primeira relação foi com ele, mas não foi legal. Ele já chegava bêbado em casa, me pegou de tudo que era jeito, foi horrível. Até que eu terminei fugindo. (...) terminaram matando ele. E aí, tudo o que ele fez comigo, ele pagou. Eu tinha uns 12, 13 anos e ele era mais velho, tinha 32.

Mas não foi com ele que eu me contaminei, foi com esse que é o pai dos meus filhos. Eu conheci ele lá no Mato Grosso. Eu já estava muito revoltada, a minha família já nem me queria dentro de casa. Tinha vez que eu ficava até na rua, não tinha pra onde ir. Já estava tudo perdido mesmo. Aí eu conheci esse moço e vim embora com ele, na cara e na coragem. Esse aí, vai fazer 33 anos. Eu tinha uns 14 anos. Ele era bem mais velho. Mas o que aparecesse de bom pra mim, eu tava. Não tinha onde ficar, tinha vez que nem tinha o que comer... aí, tive que aceitar esse mesmo, ao menos estava trabalhando, tinha alguma coisa, né?

Aí, ele já morava aqui, viemos pra cá. Foi um ótimo marido... com todos os defeitos... Nunca vivi tão feliz, como ao lado dele. Eu fui muito feliz ao lado dele, até que fiquei grávida. Quando eu fiquei grávida, eu não sabia... aí, quando fiquei sabendo... quando tive neném, fiquei sabendo. Já vai fazer 5 anos amanhã.

Tem horas que eu penso que, se não fosse ficar grávida deles (gêmeos), eu não ia saber nunca. Eu achava muita diferença nele, só podia ter vindo dele. Porque, como se chama esses homens que gostam de coisas de mulher? Porque ele usava todas as minhas calcinhas, tinha um jeito diferente..., então, eu achava que ele ia mais com homem. Aí, fui notando as diferenças. E, às vezes, chego a imaginar que, como tinha vezes que ele chegava muito agressivo em casa, que ele devia usar drogas também. Então, de alguma coisa, surgiu isso com ele.

Depois disso, eu ainda fiquei 3 meses dentro de casa. Mas aí, vi que ia matar os meus filhos, porque eu não tinha cabeça pra cuidar deles. E nossa relação, nós dois, mudou completamente. Era briga e mais briga, ele me batendo e eu batendo nele. Ele me machucando e eu machucando ele. Aí, foi indo e nós terminamos separando.

Com essa separação, fiquei morando 3 meses sozinha. A dona da casa ficou sabendo da minha situação e me deixou ficar na casa. Eu destruí toda a minha vida, eu destruí tudo o que eu tinha. Tinha uma casa montadinha, mas destruí tudo. 
Tentei ir para Campo Grande, gostei de um moço de lá, mas pra ficar... é difícil. Lá em Campo Grande eu via o meu irmão naquele sofrimento, até o copo dele não podia pegar. E ele era filho do próprio sangue, imagine eu. Às vezes, eu chegava na casa das minhas cunhadas e elas falavam assim pra mim: "Vai embora daqui." Então, preferi me virar aqui, mesmo sozinha, eu e meus filhos. Procurei um lugar pros meus filhos, um lugar pra mim...

Eles estão na Casa ... (Casa de Apoio).Pretendo ainda arrumar outro serviço e pegar eles de volta. Depois que aconteceu tudo isso comigo, nunca mais fui ver meus filhos. Nunca mais. Nem vou, nem ligo...

Nunca mais encontrei com ele, nem quero. Por ele, eu ficava com ele até hoje, mas eu não aceitei. Eu, na minha cabeça, sou louca. Eu não quis, não dava mais certo, nós brigava muito. Ele fazia todo o esforço pra gente continuar, ele falava que nós tinha dois filhos pra criar... nem isso entrou na minha cabeça, eu fiquei muito louca... acho que, até hoje, ainda não voltei ao normal. Falaram pra mim que ele estava muito doente. Eu tenho pena dele. Mas não sinto falta, vontade, nada... Acho que o que ele fez, não tem perdão.

O sujeito 09 tem 22 anos. Está separada há 5 anos, desde que ficou ciente de sua soropositividade, no parto dos filhos gêmeos.

É soropositiva sintomática, com quadro de herpes genital e encefalite, com várias internações hospitalares. Encontra-se em tratamento com medicamentos.

Após ser encontrada perambulando pelas ruas, foi encaminhada por um policial para a CETREM, onde ainda se encontra. 


\title{
SÍNTESE DA HISTÓRIA DE VIDA 10
}

\author{
"... sem ter, assim, uma história, uma coisa que você \\ soubesse, uma coisa que te levasse a pensar... eu \\ não tinha idéia. Eu acreditava piamente em mim, \\ que eu era HIV negativo e pronto, acabou."
}

Minha infância foi pequena. Foi até os 8 anos. Com 9, eu já trabalhava. Meus pais sempre tinham muitos problemas. Meu pai sempre doente, com epilepsia. Então, eu tinha muita falta, muita fome. Então, nós, eu principalmente, comecei a trabalhar com 9 anos, em casa de família, olhando criança. Com 12 anos, eu larguei a escola pra trabalhar num período maior. Aí, fui trabalhar na roça, colhendo algodão, café, tudo. Até os 15 anos.

Com 15 anos, eu saí de casa pra morar com meu primeiro marido. Vivemos juntos de 1984 à 1985. Foi um casamento muito bagunçado. Muitas idas e voltas, muita desilusão, muita coisa que, hoje em dia, eu não viveria tudo de novo. Só restou os três filhos mais velhos. Eu adorava ele. A minha vida era ele. Por isso, acho que durou tanto tempo, com tudo o que aconteceu. As traições, as saídas dele, que nunca estava em casa. Tudo o que eu fazia e trabalhava e lutava pra construir pra nós e nossos filhos, ele jogou fora da noite pro dia. E eu, em casa, trabalhando e cuidando dos filhos. Tinha meu pai e minha mãe que eu cuidava também, na época. Até que durou tudo isso, até que eu fechei, parei aqui.

A ultima vez que a gente voltou foi em 1993. Eu já não queria mais. Tentei dar uma ultima chance. Aí, em 95, ele aprontou outra. Então, eu disse: "Saí daquì". Foi a ultima vez que a gente teve junto. Depois disso, ele visitava sempre os filhos e só. Mas, ele se achava meu dono. Não se achava meu marido, se achava meu dono.

Eu fiquei sozinha até 97. Aí, conheci o atual. Eu gosto dele. Não vou dizer que tenho o mesmo amor, que acho que amor a gente só tem uma vez na vida. É o meu modo de pensar. Mas, eu gosto bastante dele, temos uma boa convivência, é bastante compreensivo, totalmente ao contrário do outro. Só que o problema que tem é o ciúme, que é doentio.

Foi no pré-natal deste ultimo neném, no mês dele nascer, que eu soube que tinha HIV. Ah! Foi tirar o chão. Eu tava já no fim da gravidez (...), aí o posto me chamou de novo, que havia tido um problema com o meu sangue. Na hora eu liguei pro meu marido pra ele ir lá no posto, porque eu tava lá na Matter. De lá, vim direto no posto. Aí, comecei a ver o que seria. Nem imaginava. Justamente por eu já ter feito, há um ano e pouco. Antes fosse no primeiro pré-natal, até que eu poderia ficar meio na dúvida. Poderia até ter uma idéia. Mas, nos segundo pré-natal, sem ter, assim, uma história, uma coisa que você soubesse, uma coisa que te levasse a pensar... eu não tinha idéia. Eu acreditava piamente em mim, que eu era HIV negativo e pronto, acabou.

Quando eu engravidei da minha primeira menina, eu fiz exames no convenio e ainda pedi que fizesse esse exame, porque eu tinha trocado de marido, tava com uma pessoa diferente e eu queria saber. Justamente por causa do meu 
relacionamento com o meu marido anterior, que era bastante à vontade. Por isso, eu pensava que não tinha nada, por eu ter pedido o exame, ter feito, ter conversado com o médico. Eu me lembro das palavras dele até hoje: "Graças à Deus, não deu nada." Você se tranquiiliza e, quando vê, cai uma bomba na sua cabeça.

Bom, mas eu não consegui saber o resultado porque o médico, acho que ele não entendia bem do exame. Ele pediu que a gente voltasse lá outro dia, que ele ia conversar com alguém que entendesse do exame, pra dar pra gente. Fomos pra casa, a cabeça à mil, e no outro dia a gente voltou lá e ele deu o resultado.

Depois de você saber que tem um problema com o seu sangue, aí o seu pensamento já vai pra tudo o que é lado. Se fosse uma coisa simples, ninguém ia te chamar, ia mandar lá onde eu tava. Ah! Sei lá. Tira o chão, falta o ar, fica naquilo lá até você tentar acordar. Eu acho que, pra ele, também foi a mesma coisa. De modo que ele também não sabia. Se soubesse, pelo que conheço dele, eu não acredito que faria isso, ficar quieto sabendo. Principalmente porque ele adora os filhos. E é um vírus pros filhos, não só pra mim. Por isso, eu acredito que ele não sabia.

Para mim, agora tudo mudou. Mudou, assim, o tempo que tinha antes pra ficar com os meus filhos, agora eu ando atrás de médico. Agora, eu tenho que andar mais, cuidar mais da minha saúde do que antes. Antes, pra mim, primeiro eram os meus filhos, minha casa, meu serviço. Agora, se eu fizer isso, amanhã não vou estar lá pra cuidar deles. Mudou nisso.

Com o meu marido, a mesma coisa de sempre. A gente sempre conversou. Sempre converso sobre isso, porque muitos casais se separam ao saber uma notícia dessas. Não, por isso não. Se a gente chegar a separar, não vai ser por esse motivo.

O sujeito 10 tem 32 anos. Estudou até a $5^{\text {a }}$ série do ensino fundamental e trabalha como auxiliar de limpeza. É casada, pela segunda vez, há 3 anos e 6 meses. Deste casamento, tem dois filhos, um menino de 5 meses e uma menina de 1 ano e 9 meses. Do casamento anterior, tem 3 filhos, dois meninos de 14 e 12 anos, e uma menina de 9 anos. Todos com sorologia negativa.

Teve conhecimento do seu status soropositivo há 6 meses, no ultimo mês do pré-natal. Acredita ter sido contaminada pelo marido atual, com base nos exames do pré-natal anterior. $\mathrm{O}$ marido, somente agora, concordou em fazer o teste e aguarda o resultado. 


\section{REFERÊNCIAS BIBLIOGRÁFICAS}

ARAUJO, D. R. D. O amor no feminino: ocultamento e/ou revelação? 2000. Tese de Doutorado - Instituto de Psicologia, Universidade de São Paulo, São Paulo.

ARCHANJO, L.R. Relações de gênero no Colégio Estadual do Paraná (1950/1960). In: ADELMAN, M.; SILVESTRIN, C.B. (Orgs). Coletânea Gênero Plural. Curitiba: UFPR, 2002, p.191-201

ARIÈS, P., O amor no casamento. In: ARIÈS, P.; BÉJIN (orgs.). Sexualidades Ocidentais. São Paulo: Brasiliense, 1985.

ÁVILA, M.B.; GOUVEIA, T. Notas sobre direitos reprodutivos e direitos sociais. In: PARKER, R.; BARBOSA R. M. (orgs). Sexualidades brasileiras. Rio de Janeiro: Relume-Dumará/ABIA/IMS/UERJ, Cap. 10, p. 160-172, 1996

AYRES, J. R. C. M.; FRANCA JR., J., CALAZANS, G.J. AIDS, vulnerabilidade e prevenção. Apostila, 1999.

AYRES, J.R.C.M. Repensando Conceitos e Práticas em Saúde Pública.In: PARKER, R.; TERTO JR., T. (Org.). Aprimorando o debate: respostas sociais frente à Aids. Rio de Janeiro: ABIA, 2002. p.12-19.

AZEVEDO, M. et al. Mulheres espancadas: a violência denunciada. São Paulo: Cortez, 1985.

BARBOSA, R. M.; LAGO, T. G. AIDS e direitos reprodutivos: para além da transmissão vertical. In: PARKER, R.(org.). Políticas, instituições e AIDS: enfrentando a epidemia no Brasil. Rio de Janeiro: Jorge Zahar Ed./ABIA, 1997.

BARBOSA, R.M.S. Mulheres, reprodução e Aids: as tramas da ideologia na assistência à saúde de gestantes HIV+. Doutorado. Fundação Oswaldo Cruz, Escola Nacional de Saúde Pública, 2001, 310 p.

BASTOS, F. I. A feminização da AIDS no Brasil: determinantes estruturais e alternativas de enfrentamento. Coleção ABIA: Saúde Sexual e Reprodutiva, Rio de Janeiro, $\mathrm{n}^{\mathrm{O}}$ 03, 2000.

BASTOS, F. I. et al. A epidemia de Aids no Brasil. In: Minayo, M. C. S. (Org.). Os muitos Brasis: saúde e população na década de 80. São Paulo: Editora Hucitec; Rio de Janeiro: ABRASCO, 1995.

BASTOS, F. I.; SZWARCWALTZ, C. L. AIDS e pauperização: principais conceitos e evidências empíricas. Cadernos de Saúde Pública, Rio de Janeiro, 16(Sup. 1): 65-76, 2000. 
BASTOS, F.I.. Uso de drogas injetáveis e transmissão do HIV entre casais: comentários. In: MAKSUD, I. et al (Orgs). Conjugalidade e Aids: a questão da sorodiscordância e os serviços de saúde Rio de Janeiro: ABIA, 2002. p. 119-124

BERGER, P. L.; LUCKMANN, T. A construção social da realidade. Petrópolis: Vozes, 1973.

BERLINGUER, G. Evolução da Medicina Social. In: Medicina e Política. São Paulo, CEBES-HUCITEC, 1978.

BESSE, S.K. Modernizando a desigualdade: Reestruturação da ideologia de gênero no Brasil, 1914-1940. São Paulo: EDUSP, 1999.

BOGDAN, R.; BIkLEN, S. Investigação Qualitativa em Educação. PortugalPorto: Porto Editora, 1997.

BOLTANSKI, L. As classes sociais e o corpo. Rio de Janeiro: Edições Graal, 1989.

BRASIL, Ministério da Saúde. Boletim Epidemiológico - AIDS. Brasília: CNDST/AIDS, Ano XVI(01), 2002.

BRASIL, Ministério da Saúde. CNS. Resolução 196/96 sobre pesquisa envolvendo seres humanos. 1996.

BRASIL, Mistério da Saúde. Boletim Epidemiológico - AIDS. Brasília: CNDST/AIDS. Ano XII (02), 1999.

BRASIL. Ministério da Saúde. Boletim Epidemiológico - AIDS. Brasília: CNDST/AIDS. Ano XV (01), 2001.

BRUSCHINI, M.C.; Maternidade e trabalho feminino. In: ARILHA, M., Reflexões sobre gênero e fecundidade no Brasil. Disponível em: http://www.fhi.org/sp/ barbrosp.html. Acesso em: 21 mar 2002.

BUCHALlA, C.M.; PAIVA, V.; Da compreensão da vulnerabilidade social ao enfoque multidisciplinar. Revista Saúde Publica, 36 (4 Supl.), p. 117-119, 2002.

CAMARGO JR. K.R., Aids e a Aids das ciências. O discurso médico e a construção da Aids. Rio de Janeiro: Abia/IMS/RJ/Relume-Dumará, 1994.

CAMPOS, R. Em A nova fórmula do casamento. Revista Viver. São Paulo: Segmento, ano VII, $n^{\circ} 87$, abril de 2000.

CARNEIRO, H. F. C. AIDS: a nova desrazão da humanidade. São Paulo: Escuta, 2000.

CASTELls, M., A era da informação. In: A sociedade em rede. Rio de Janeiro: Paz e Terra, 1999.

CASTILHO, E.; CHEQUER, P. A epidemiologia do HIV/AIDS. In: Políticas, 
Instituições e AIDS: enfrentando a epidemia no Brasil. Rio de Janeiro: Jorge Zahar Edit./ABIA, 1997.

COSTA, J. F., Sem fraude, nem favor: estudos sobre o amor romântico. Rio de Janeiro: Roco, 1999.

COSTA, S. G. Saúde, Gênero e Representações Sociais. In: MURARO, R.M. \& PUPIN, A.B. (orgs.). Mulher, Gênero e Sociedade. Rio de Janeiro: RelumeDumará/FAPERJ, 2001, P. 112-123.

CZERESNIA, D. AIDS, contágio e transmissão. Relações entre epidemia, cultura e ciência. In: et al. AIDS: ética, medicina e biotecnologia. São Paulo: HUCITEC; Rio de Janeiro: ABRASCO, Cap. 3, p. 51-76, 1995

DEANE, P., O ponto de partida. In: .A Revolução Industrial, $3^{\text {a }}$ ed., Rio de Janeiro: Zahar, 1975.

DEJOURS, C. Por um novo conceito de saúde. Revista Brasil. de Saúde Ocupacional. V.14, n. 54, p. 7-11, 1986.

DENZIN, N.K. The research act: a theoretical introduction to sociological methods. $3^{\text {a }}$ ed, Englewood Cliffs: Prentice Hall, 1989.

DICKS, H. Tensões conjugais, Londres: Karnac Books, 1993.

FAUNDES, D. Reprodução Assistida e HIV/AIDS. In: MAKSUD, I. et al (Orgs). Conjugalidade e Aids: a questão da sorodiscordância e os serviços de saúde Rio de Janeiro: ABIA, 2002. p. 57-62.

FERNÁNDEZ, A.M. La mujer de la ilusión. Buenos Aires: Paidos.1994.

FERREIRA, C. V. L. Aids e Vida: um estudo clínico-psicanalítico com pacientes HIV. São Paulo: Lemos Editorial; Uberlândia, MG: Editora da UFU, 1994.

FERREIRA, M.P.S.; AIDS: Da violência aos direitos humanos à construção da solidariedade. 1999. Dissertação de Mestrado. Pós-Graduação em Saúde Pública, Escola Nacional de Saúde Pública, Fundação Osvaldo Cruz.

FIGUEIREDO, M.A.C. et al. Profissionais de Saúde e Aids. Um estudo diferencial. Medicina. Ribeirão Preto, 26(3), abr/jun, p.393-407, 1993

FIGUEIREDO, M.A.C.; Aids, Ciência e Sociedade: A dicotomia entre conhecimento técnico e competência social no trabalho do profissional de saúde. In: BOARINI, M.L. Desafios na atenção à Saúde Mental. Londrina, Editora Universidade de Londrina, 2000b, Capítulo 4 (p. 79-92).

; Algumas questões psicossociais do atendimento a pessoas que convivem com o HIV/Aids, sob o ponto de vista de um grupo de profissionais de saúde. Jornal Brasileiro de Aids, 2 (1), jan/fev/mar, p. 17-24, 2001. 
; Estudo de Representações sobre Aids em pacientes, para a formação profissional visando grupos de suporte para pessoas contaminadas pelo HIV, sintomáticas ou não.Jornal Brasileiro de Aids., 1 (5), out/nov/dez, p. 22-31, 2000a

; Grupos de suporte para profissionais que atendem pacientes com Aids na Unidade Especial de Terapia de Doenças Infecciosas (UETDI) do HCFMRP-USP.Ribeirão Preto, Sub-projeto 2C, 1997. Disponível em http://papsi.ffclrp.usp.br

FIGUEIREDO, M.C.; RIBEIRO, D. F. A devolução do diagnóstico anti-HIV positivo. In: O ponto de vista do paciente com AIDS a respeito do atendimento clinico recebido. FFCLRP-USP, 1996.

FIGUEIREDO, R.; AYRES, J.R.; Intervenção comunitária e redução da vulnerabilidade feminina de mulheres às DST/AIDS em São Paulo. Revista Saúde Publica, 36 (4 Supl.), p. 96-107, 2002.

FILGUEIRAS, S.L.; DESLANDES, S.F.; Avaliação das ações de aconselhamento. Análise de uma perspectiva de prevenção centrada na pessoa. Cad. Saúde Pública, Rio de Janeiro, 159Sup. 2) p. 121-131, 1999)

FISCHER, I. R.; MARQUES, F. Gênero e exclusão social. Disponível em http://www.fundaj.gov.br/tpd/113.html. Acesso em: 06 de setembro de 2001.

FREUD, S. (1905). Três ensaios sobre a teoria da sexualidade. Tradução De Paulo C. D. Correa. Rio de Janeiro: Imago Ed., 1997.

GALVÂO, J. AIDS no Brasil: a agenda de construção de uma epidemia. Rio de Janeiro: ABIA; São Paulo: Ed. 34, 2000.

GAUDERER, E.C.; Reação do Profissional frente à doença crônica ou fatal. Jornal Brasileiro de Medicina, 40 (3), mar, pág. 47-56, 1981.

GERTZ, C. A interpretação das culturas. Rio de Janeiro: Zahar, 1989

GIDDENS, A. A transformação da intimidade: sexualidade, amor e erotismo nas sociedades modernas. São Paulo: Editora da Universidade Estadual Paulista, 1993.

GIR, E. A sexualidade e a mulher portadora do vírus da imunodeficiência humana tipo 1 (HIV-1), 1997. Tese de livre docência - Escola de Enfermagem de Ribeirão Preto - USP.

GOFFMAN, E. A representação do eu na vida cotidiana. Petrópolis: Vozes, 1985.

Estigma: notas sobre a manipulação da identidade deteriorada.

Rio de Janeiro: Guanabara, 1988.

GORDON, R. A assustadora história da medicina. São Paulo: Ediouro, 2002. 
GUERRIERO, I.; AYRES, J. R; HEARST, N. Masculinidade e Vulnerabilidade a HIV de homens, São Paulo, SP. Rev. Saúde Pública, 36 (4 Supl), p. 50-60, 2002.

GUIMARAES, K. Nas raízes do silencio: a representação cultural da sexualidade feminina e a prevenção do HIV/AIDS. In: PARKER, R.; GALVÃO, J. (orgs.). Quebrando o silencio: mulheres e AIDS no Brasil. Rio de Janeiro: ABIA/IMS/UERJ/Relume-Dumará, p. 89-113, 1996.

HEILBORN, M.L.; GOUVEIA, P. Marido é tudo igual: mulheres populares e sexualidade no contexto da Aids. In: PARKER, R.; BARBOSA, R. M. (Orgs). Sexualidades pelo avesso: direitos, identidade e poder. Rio de Janeiro: IMS/UERJ:Ed 34, 1999.

HEILBORN, M.L. Construção de si, gênero e sexualidade. In: (Org). Sexualidade: o olhar das ciências sociais. Rio de Janeiro: Jorge Zahar, 1999, p. 4058 .

Ser ou estar homossexual: dilemas de construção de identidade social. Iin: PARKER, R.; BARBOSA, R.M. (Orgs). Sexualidades Brasileiras, Rio de Janeiro: Relume-Dumará, 1996, p. 136-148.

HELLER, H, O cotidiano e a história. São Paulo: Paz e Terra, $4^{\text {a }}$ ed., 1992.

HERRERA, C.; CAMPERO, L. La vulnerabilidad de las mujeres ante el VIH/SIDA: consantes y cambios en el tema. Salud Publica Mex.; Vol. 44, p. 554-564, 2002.

HERZLICH, C. A problemática da representação social e sua utilidade no campo da doença. Phisys, Vol. 1, n. 2, p. 23-36, Rio de Janeiro: IMS/Relume-Dumará, 1991.

HERZLICH, C.; PIERRET, J. Illness: from cause to meaning. In: CURER, C.; STACEY, M. (orgs.). Concepts of health, illness and disease: a comparative perspective. Oxford: Berg, 1993.

KELLY, J. D. Group Psychotherapy for persons withHIV and AIDS-related illnesses. International Journal of Group Psychotherapy, V. 48, n. 2, p. 143-162.

KNAUTH, D. Comentários. In: MAKSUD, I. et al (Orgs). Conjugalidade e Aids: a questão da sorodiscordância e os serviços de saúde Rio de Janeiro: ABIA, 2002. p. $37-42$.

KORNBLIT, A.L.; DIZ, A.M.M. La prueba del VIH como estrategia de la poblacion frente al riesgo de infección. In: KORNBLIT, A.L. (Org). Sida: entre el cuidado y el riesgo: estudios en poblacion general $\mathbf{y}$ en personas afectadas. Buenos Aires: Alianza, 2000, p. 131-148.

KORNBLIT, A.L.; DIZ, A.M.M. Las logicas del amor. In: KORNBLIT, A.L. (Org). Sida: entre el cuidado $\mathrm{y}$ el riesgo: estudios en poblacion general $\mathrm{y}$ en personas afectadas. Buenos Aires: Alianza, 2000c, p. 111-132.

KORNBLIT, A.L.; DIZ, A.M.M. Las personas afectadas por práticas 
heterossexuales In: KORNBLIT, A.L. (Org). Sida: entre el cuidado y el riesgo: estudios en poblacion general $\mathbf{y}$ en personas afectadas. Buenos Aires: Alianza, 2000, p.293-356.

LAGO, R.F. Bissexualidade masculina: dilemas de construção de identidade sexual. Dissertação de Mestrado em Saúde Cooletiva, IMS/UERJ, Rio de Janeiro.

LANE, S. T. M. Usos e abusos das representações sociais. In: SPINK, M. J. P. (org.). $\mathrm{O}$ conhecimento no cotidiano: as representações sociais na perspectiva da psicologia social. São Paulo: Brasiliense, p. 58-72, 1995.

LARVIE, P. Homophobia and ethnoscape of sex work in Rio de Janeiro. In: HERDT, G. Sexual Culture and Migration in the era of Aids: anthropological and demographic perspectives. Oxford: Clarendon, 1997, p. 143-164.

LAURELl, C.; NORIEGA, M. Processo de produção e saúde. Trabalho e desgaste operário. São Paulo: HUCITEC, 1989.

LEAL, F.; BOFF, Em M. Insultos, Queixas, Sedução e Sexualidade: Fragmentos de identidade masculina em uma perspectiva relacional. In: PARKER, R.; BARBOSA, R. M. Sexualidades brasileiras. Rio de Janeiro: Relume-Dumará/ABIA/IMS/UERJ, Cap 7, p. 119-135, 1996.

LEAL, F.; FACHEL, J. M. G. Jovens, sexualidade e estratégias matrimoniais. In: HELBORN, M. L. (org.). Sexualidade: o olhar das ciências sociais. Rio de Janeiro: Jorge Zahar Ed., Cap. 6, p. 96-116, 1999.

LÉVI-STRAUSS Antropologia estrutural. 2 $2^{\mathrm{a}}$ edição, Rio de Janeiro: Tempo Brasileiro, 1967.

LOBATO, J. P., Amor, desejo e escolha. Coleção Gênero: Rio de Janeiro: Record/Rosa dos Tempos, 1997.

LUPTON, D. et al. Doing the right thing: the symbolic meanings and experience of having an VIH antibody test. Social Science and Medicine, 41 (2), 1995, p . 173180.

MAKSUD. I. Casais com sorologia distintas para o HIV: questões iniciais para debate. In: MAKSUD, I. et al (Orgs). Conjugalidade e Aids: a questão da sorodiscordância e os serviços de saúde Rio de Janeiro: ABIA, 2002. p. 11-20.

MALBERGIER, A. Os médicos diante do paciente com Aids: atitudes, preconceitos e dificuldades. In.: Aids e Psiquiatria. Um guia para profissionais de saúde. Rio de Janeiro: Revinter, 2000, Cap. 16, p. 76-107.

MANN, J. et al. (org.) A AIDS no mundo. Rio de Janeiro: RelumeDumará/ABIA/IMS/UERJ, 1993.

MARTINS, A.P.V. A ciência do feminino: a constituição da obstetrícia e da ginecologia. In: ADELMAN, M.; SILVESTRIN, C.B. (Orgs). Coletânea Gênero 
Plural. Curitiba: UFPR, 2002, p.101-116.

MATIDA, L. H., MIRANDA, S. D. É possível a redução da transmissão materno infantil do HIV. Jornal Brasil. de AIDS, Vol. 1, n. 30, p.9-11, abr, mai,juh, 2000.

MATOS, M. Reinvenções do Vínculo Amoroso. Cultura e identidade de gênero na modernidade tardia. Belo Horizonte: UFMG, Rio de Janeiro: IUPERJ, 2000.

MENDES-GONÇALVES, R.B.M.; Tecnologia e organização social das práticas de saúde: características tecnológicas do processo de trabalho na Rede Estadual de Centro de Saúde de São Paulo. São Paulo: Hucitec/Abrasco, 1994.

MINAYO, M. C. O desafio do conhecimento: pesquisa qualitativa em Saúde. São Paulo - Rio de Janeiro: HUCITEC/ABRASCO, 5ª ed., 1998.

MINAYO, M.C.S. Estrutura e sujeito, determinismo e protagonismo histórico: uma reflexäo sobre a práxis da saúde coletiva. Ciênc. saúde coletiva; 6(1):7-47, 2001.

MURARO, R.M. Breve Introdução Histórica. In: KRAMER, H.; SPRENGER, J. Malleus Maleficarum. O martelo das feiticeiras. Rio de Janeiro: Rosa dos Tempos, 1991.

MUZA, G.M., COSTA, M.P. Elementos para a elaboração de um projeto de promoção à saúde e desenvolvimento dos adolescentes - o olhar dos adolescentes. Cadernos de Saúde Pública, Rio de Janeiro, 18 (1), p. 321-328, jan-fev, 2002.

NARDI, H.C.; Saúde, Trabalho e Discurso Médico. São Leopoldo: Ed. Unisinos, 1999.

NYE, Em, Teorias Feministas e as Filosofias do Homem. Tradução: Nathanael C. Caixeiro. Rio de Janeiro: Record/ Rosa dos Tempos, 1995.

OLIVEIRA, M. C. C. Singularidades do Luto por Aids em Mulheres - As Viúvas da Aids. 2000. Dissertação de Mestrado - Programa de Psicologia Clínica da PUC/SP.

Trabalhando perdas na escola: luto, ausência e outras perdas. In: PINTO, T.; TELLES, I. S. AIDS e escola: reflexões e propostas do Educaids. São Paulo: Cortez; Pernambuco:UNICEF, 2000.

PAIVA, V. Fazendo arte com a camisinha: sexualidades jovens em tempos de AIDS. São Paulo: SUMMUS, 2000.

PALMA, I. M. ; QUILODRÁN, C. L. Respostas à gravidez entre adolescentes chilenas de estratos populares. In: COSTA; AMADO, T. (orgs). Alternativas escassas: saúde, sexualidade e reprodução na América Latina. São Paulo: PRODIR/FCC; Rio de Janeiro: Ed. 34, 1994.

PAPSI - Programa de Atendimento Psicossocial à Aids. Departamento de Psicologia

e Educação, FFCLRP USP, Ribeirão Preto- SP. Disponível em 
<http://papsi.ffclrp.usp.br> Acesso em 24/05/2003.

PARKER, R.; AGGLETON, P. Estigma, discriminação e Aids. Rio de Janeiro: ABIA. Série Cidadania, n. 1, 2001.

PARKER, R. , (org). Políticas, Instituições e Aids: enfrentando a epidemia no Brasil. Rio de Janeiro: Jorge Zahar Ed./ABIA, 1997.

Na contramão da AIDS: sexualidade, intervenção, política. Rio de Janeiro: ABIA; SÃO Paulo: Ed. 34, 2000.

A construção da solidariedade: AIDS, sexualidade e política no Brasil. Rio de Janeiro: ABIA/UERJ/Editora Relume-Dumará, 1994.

PARKER, R.; CAMARGO JR., K. R. Pobreza e HIV/AIDS: aspectos antropológicos e sociológicos. Cadernos de Saúde Pública, Rio de Janeiro, 16(Sup. 1): 89-102, 2000.

PAULILO, M. Em S. AIDS: os sentidos do risco. São Paulo:Veras Editora, 1999.

PEREIRA, M. L. D.; CHAVES, E. C. Ser mãe e estar com AIDS: o revivescimento do pecado original. Revista Escola Enfermagem USP, V. 33, n.4, p. 404-410, dez, 1999.

PINEZI-BARBOSA, A.K.P. A família de fá em tempos modernos: uma interpretação sobre a constituição familiar, relações de gênero e sexualidade entre presbiterianos. Dissertação de Mestrado., Programa de Pós-Graduação em Psicologia, Universidade de São Paulo, Ribeirão Preto, SP.

PLASTINO, C. Em Globalização e mal-estar na cultura. Rio de Janeiro: IMS/UERJ, 1997.

POLEJACK, L. Projeto Com-Vivência: trabalhando com casais sorodiferentes para HIV/AIDS. In: MAKSUD, I. et al (Orgs). Conjugalidade e Aids: a questão da sorodiscordância e os serviços de saúde Rio de Janeiro: ABIA, 2002. p. 27-36.

PORTELLA, A.P. Direitos Reprodutivos e HIV/AIDS. In: MAKSUD, I. et al (Orgs). Conjugalidade e Aids: a questão da sorodiscordância e os serviços de saúde Rio de Janeiro: ABIA, 2002. p.

PRADO , D.; OLIVEIRA, C. F. A produção social do masculino e do feminino. Jornal Brasil de Psiquiatria, V. 31, n. 1, p. 5-6, 1982.

REIS, M. M. F., Mulher: produto com data de validade. São Paulo: O nome da Rosa, 2002.

REZENDE, Em L. M., Saúde: dialética do pensar e do fazer. São Paulo: Cortez, 1986.

ROHDEN, F. Dilemas em torno das representações sociais sobre a reprodução no 
contexto do HIV/AIDS. In: MAKSUD, I. et al (Orgs). Conjugalidade e Aids: a questão da sorodiscordância e os serviços de saúde Rio de Janeiro: ABIA, 2002. p. $37-42$.

ROMERO-DAZA, N.; HIMMLGREEN, D. More then money for your labor: migration and the political economy of Aids in Lesotho. Inn: SINGER, M. (Org.). The political economy of Aids, Amittyville: Baywood Publishing Co., 1998, p. 185-204.

ROSO, A.. Ideologia e relações de gênero: um estudo de recepção das propagandas de prevenção da Aids. Cadernos de Saúde Pública, Rio de Janeiro, 16(2):385-397, abr-jun, 2000.

SÁ, C. P. Representações Sociais: o conceito e o estado atual da teoria. In: SPINK, M. J. P. (org.). O conhecimento no cotidiano: as representações sociais na perspectiva da psicologia social. São Paulo: Brasiliense, p. 19-45, 1995.

SAFFIOTI, H. I. B. A mulher ba sociedade de classes: mito e realidade. São Paulo: Quatro Artes, 1969.

SALDANHA, A. A.; DIAS, M.R.; SIDA: Exclusión social y desastre. Um estúdio de percepción com mujeres pobres. Desastres \& Sociedad Revista Semestral de La Red de Estúdios Sociales em Prevención de Sesastres em América Latina, 8(5), Enero-Diciembre, p 113-124, 1997.

SALDANHA, A.A.W. Aspectos Psicossociais da Prevenção da Aids em mulheres de baixa renda: entre o querer e o poder. 1998. Tese de Mestrado. PósGraduação em Psicologia Social. Universidade Federal da Paraíba.

SAMPAIO, C.M.A. A sorodiscordancia na interface com o uo de drogas: uma questão em debate. In: MAKSUD, I. et al (Orgs). Conjugalidade e Aids: a questão da sorodiscordância e os serviços de saúde Rio de Janeiro: ABIA, 2002. p. 113118.

SAWAIA, B. B. Análise psicossocial do processo saúde-doença. Revista Escola Enfermagem USP, V. 28, N. 01, P. 105-110, ABRIL, 1994.

- Dimensão ético-afetiva do adoecer da classe trabalhadora. In: LANE, S. T. M; SAWAIA, B. B. (orgs). Novas veredas da psicologia social. São Paulo: Brasiliense, p.157-168, 1995 b.

Representação e ideologia: o encontro desfetichizador. In: SPINK, M. J. P. (org.). O conhecimento no cotidiano: as representações sociais na perspectiva da psicologia social. São Paulo: Brasiliense, p. 73-84, 1995ª .

SILVA, N.E.K. et al. Limites do trabalho multiprofissional: estudo de caso dos centros de referencia para DST/AIDS. Revista Saúde Pública, 36 (4 Supl), p. 108$116,2002$.

SPINK, M. J. P. O estudo empírico das representações sociais. In: $\mathbf{O}$ 
conhecimento no cotidiano: as representações sociais na perspectiva da psicologia social. São Paulo: Brasiliense, p. 85-108, 1995.

Representações Sociais: questionando o estado da arte. Revista Psicologia e Sociedade.Vol. 8, n.2: 166-186, 1996.

(org.). O conhecimento no cotidiano: as representações sociais na perspectiva da psicologia social. São Paulo: Brasiliense, 1995.

SZWARCWALTZ, C. L. et al. A disseminação da epidemia de AIDS no Brasil, no período de 1987-1996: uma análise espacial. Cadernos de Saúde Pública, Rio de Janeiro, 16(Sup. 1): 7-19, 2000.

TUNALA, L. et al. Fatores Psicossociais que dificultam a adesão das mulheres portadoras do HIV aos cuidados de saúde. In: TEIXEIRA, P. R.; PAIVA, V.; SHIMMA (orgs.), E. Tá difícil de engolir? Experiências de adesão ao tratamento anti-retroviral em São Paulo. São Paulo: Nepaids, Cap.3, p. 83-114, 2000.

UNBEHAUM RIDENTI, S. G. A deseigualdade de gênero nas relações parentais: o exemplo da custódia dos filhos. In: ARILHA et al (Orgs). Homens e Masculinidades: outras palavras. São Paulo: ECO: 34, p. 163-184

VILLELA, W..Homens que é homem também pega Aids? In: ARILHA, M. Et al (Orgs). Homens e Masculinidades: outras palavras. São Paulo: ECO: 34. 